\title{
QUALIFICATION TESTING AND FULL-SCALE DEMONSTRATION OF TITANIUM-TREATED ZEOLITE FOR SLUDGE WASH PROCESSING
}

Topical Report

By

William J. Dalton

June 30, 1997

Work Performed Under Contract No. DE-AC24-81NE 44139

\section{Prepared for}

U.S. Department of Energy

Assistant Secretary for Nuclear Energy

Prepared by

\section{MASTER}

West Valley Nuclear Services Company, Inc.

West Valley, New York 14171-0191 


\section{DISCLAIMER}

This report was prepared as an account of work sponsored by an agency of the United States Government. Neither the United States Government nor any agency thereof, nor any of their employees, makes any warranty, express or implied, or assumes any legal liability or responsibility for the accuracy, completeness, or usefulness of any information, apparatus, product, or process disclosed, or represents that its use would not infringe privately owned rights. Reference herein to any specific commercial product, process, or service by trade name, trademark, manufacturer, or otherwise, does not necessarily constitute or imply its endorsement, recommendation, or favoring by the United States Government or any agency thereof. The views and opinions of authors expressed herein do not necessarily state or reflect those of the United States Government or any agency thereof.

This report has been reproduced directly from the best available copy.

Available to DOE and DOE contractors from the Office of Scientific and Technical Information, P.O. Box 62, Oak Ridge, TN 37831; prices available from (615) 576-8401, FTS 626-8401.

Available to the public from the National Technical Information Service, U.S. Department of Commerce, 5285 Port Royal Rd., Springfield, VA 22161. 


\section{DISCLAIMER}

Portions of this document may be illegible electronic image products. Images are produced from the best available original document. 
LIST OF FIGURES $\ldots \ldots \ldots \ldots \ldots \ldots \ldots \ldots \ldots \ldots \ldots \ldots \ldots \ldots \ldots \ldots \ldots \ldots \ldots \ldots \ldots \ldots \ldots$

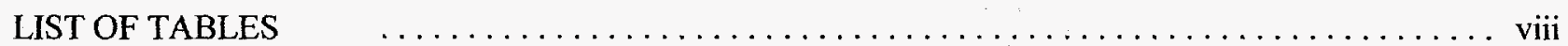

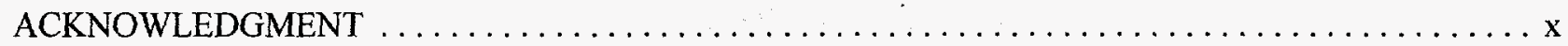

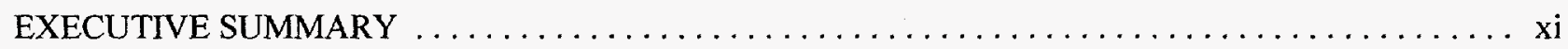

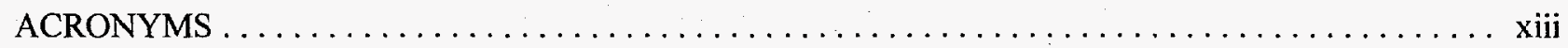

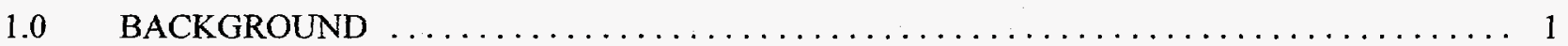

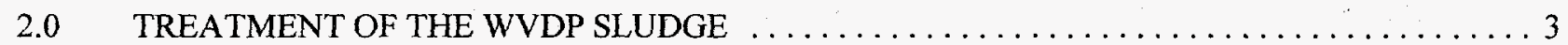

3.0 TITANIUM-TREATED ZEOLITE HISTORY $\ldots \ldots \ldots \ldots \ldots \ldots \ldots \ldots \ldots \ldots \ldots \ldots$

$4.0 \quad$ TITANIUM-TREATED ZEOLITE LABORATORY TESTING $\ldots \ldots \ldots \ldots \ldots \ldots \ldots \ldots \ldots \ldots$

4.1 WVNS-TSR-023 $R_{d}$ - "Batch Distribution" and Column-testing of Titanium-coated IE-96

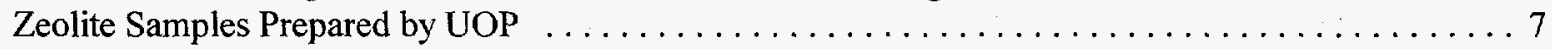

$4.1 .1 \quad$ Test Results $\ldots \ldots \ldots \ldots \ldots \ldots \ldots \ldots \ldots \ldots \ldots \ldots \ldots \ldots \ldots \ldots \ldots$

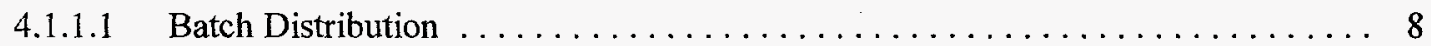

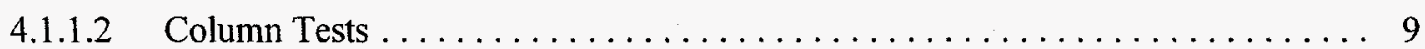

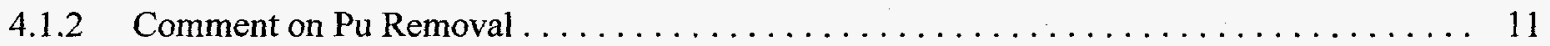

4.1.3 Discussion of Results $\ldots \ldots \ldots \ldots \ldots \ldots \ldots \ldots \ldots \ldots \ldots \ldots \ldots \ldots \ldots \ldots \ldots$

4.2 WVNS-TSR-033 - Qualification Testing on the 100-lb Pilot-scale TIE-96 Zeolite

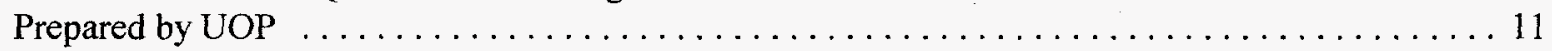

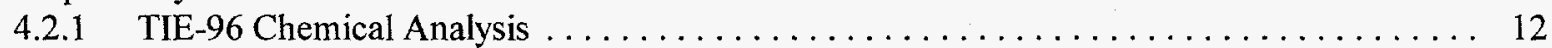

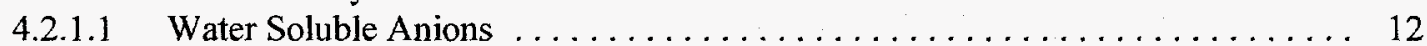

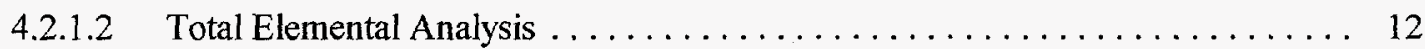

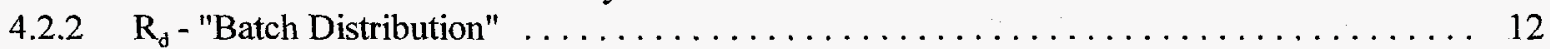

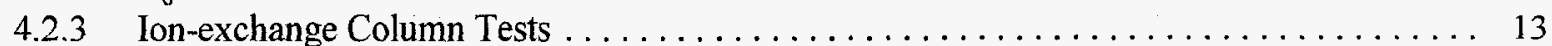

4.2 .4 Discussion of the Results $\ldots \ldots \ldots \ldots \ldots \ldots \ldots \ldots \ldots \ldots \ldots \ldots \ldots \ldots \ldots \ldots \ldots$

4.2 .5 Leaching from Zeolite $\ldots \ldots \ldots \ldots \ldots \ldots \ldots \ldots \ldots \ldots \ldots \ldots \ldots \ldots \ldots \ldots$

4.3 WVNS-TSR-037A "TIE-96 Zeolite Testing for Defining STS Operating Conditions" . . . . . . . . 24

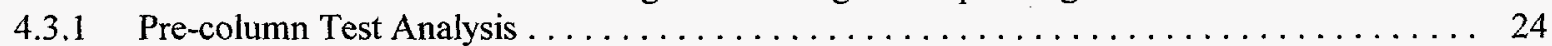

4.3.1.1 Characterization of Column-test Feed Solution $\ldots \ldots \ldots \ldots \ldots \ldots \ldots \ldots \ldots$

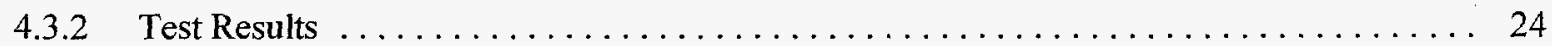

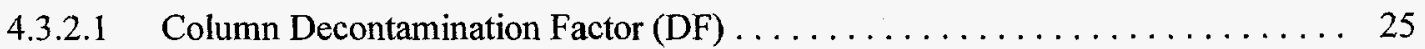

4.4 WVNS-TSR-037B "TIE-96 Zeolite Testing for Defining STS Operating Conditions" $\ldots \ldots \ldots \ldots 33$

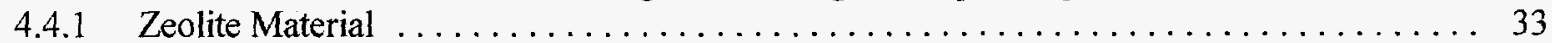

4.4.1.1 Physical Characterization and Weights of the Zeolites Used -Anhydrous Weight Percent $\ldots \ldots \ldots \ldots \ldots \ldots \ldots \ldots \ldots \ldots \ldots \ldots \ldots \ldots \ldots$

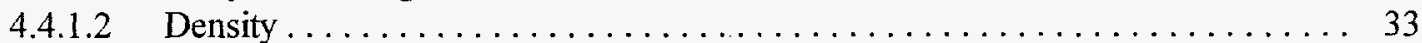

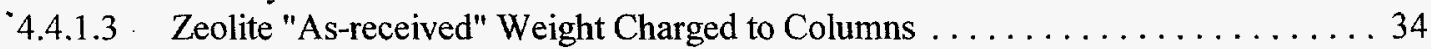

4.4.2 Characterization of Column-test Feed Solutions $\ldots \ldots \ldots \ldots \ldots \ldots \ldots \ldots \ldots \ldots \ldots$

4.4.2.1 TRQ/TP-337B Part 1 - Laboratory Sludge Wash Solutions . . . . . . . . . 34 


\section{TABLE OF CONTENTS (Continued)}

Section

4.4.2.2 TRQ/TP-037B Part 2 - Tank 8D-2 Sludge Wash Solution ............ 35

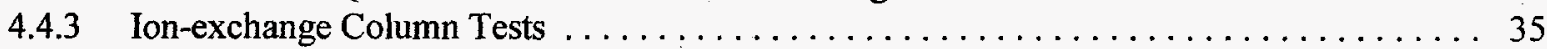

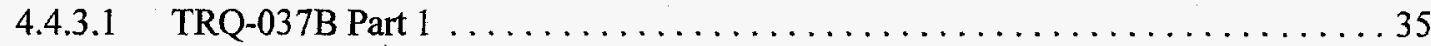

4.4.3.1.1 Column Temperature and Column Feed Solution Flow Rate . . . . . . 36

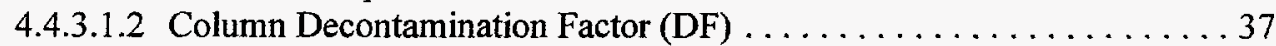

4.4.3.1.3 Comparison to TP-037A ...................... 41

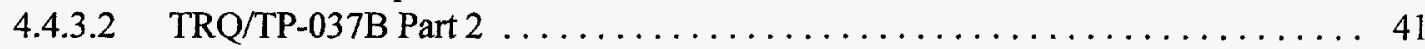

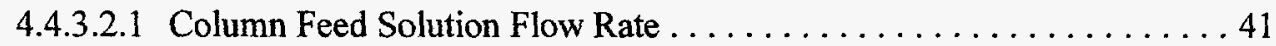

4.4.3.2.2 Column Decontamination Factor (DF) . . . . . . . . . . . 41

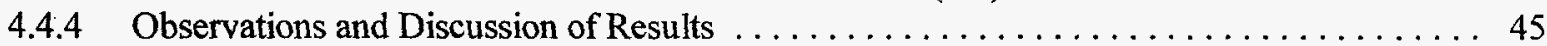

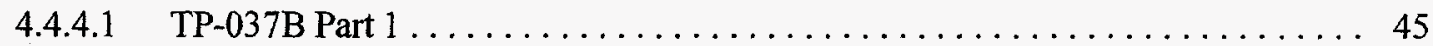

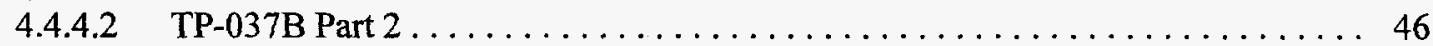

4.5 WVNS-TSR-042 - "STS Column-loading Verification with TIE-96 Zeolite" . . . . . . . . . . . 47

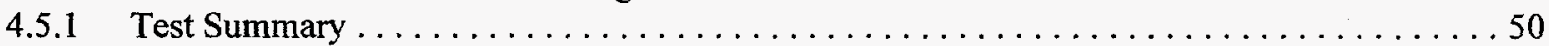

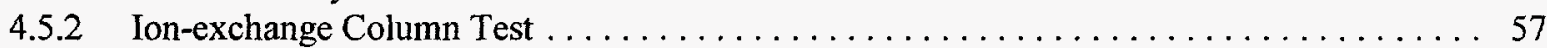

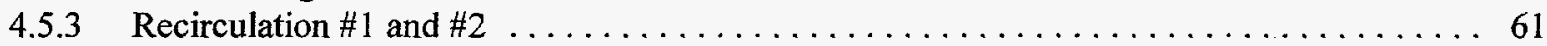

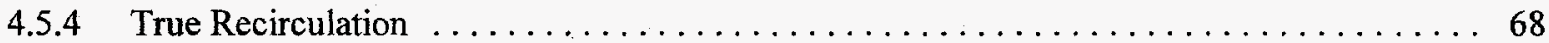

4.5.5 Demineralized Water and Bicarbonate Rinses $\ldots \ldots \ldots \ldots \ldots \ldots \ldots \ldots \ldots \ldots . \ldots 6$

4.5.6 Application of TP-042 Results to IRTS Operation $\ldots \ldots \ldots \ldots \ldots \ldots \ldots \ldots \ldots$

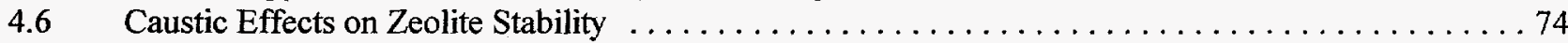

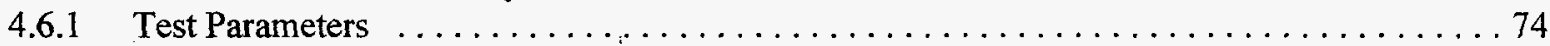

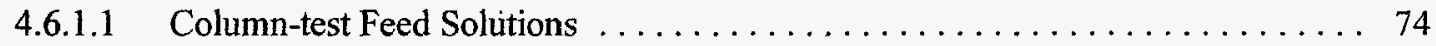

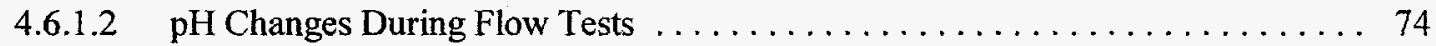

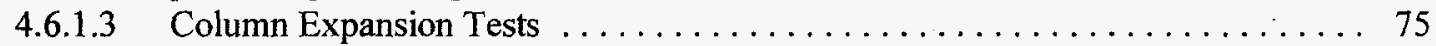

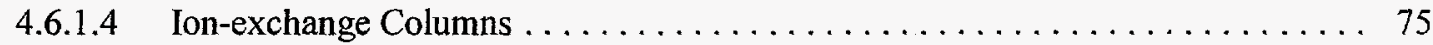

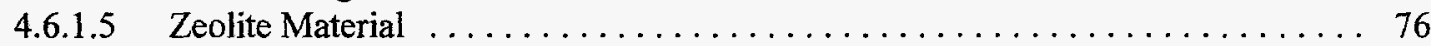

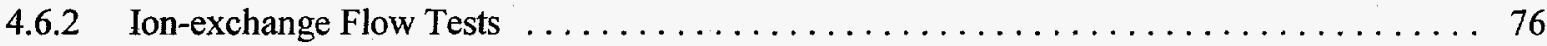

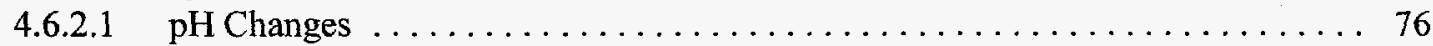

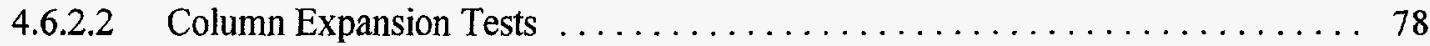

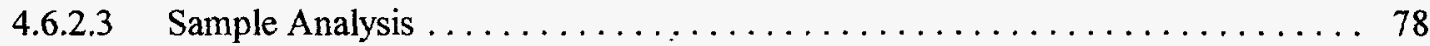

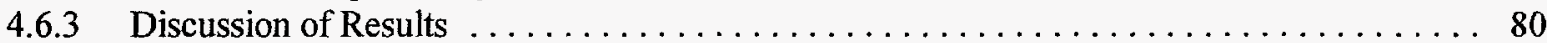

$4.7 \quad$ Caustic Effects on Ion-exchange IONSIV IE-96 and TIE-96 Zeolite $\ldots \ldots \ldots \ldots \ldots \ldots \ldots \ldots \ldots$

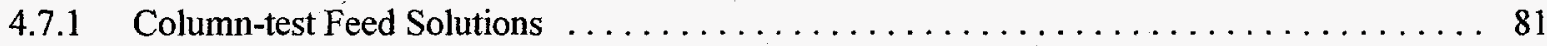

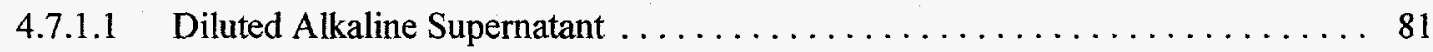

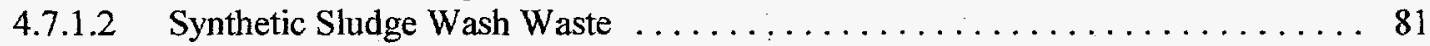

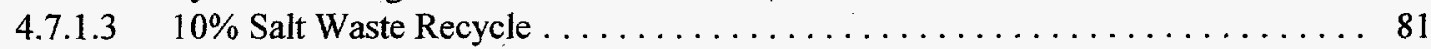

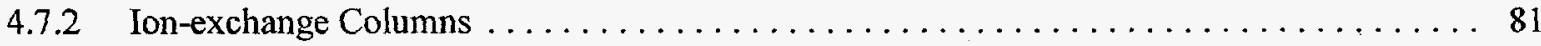

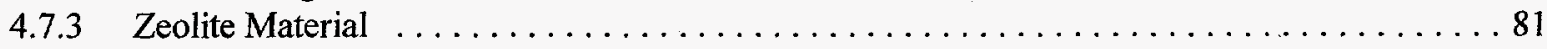

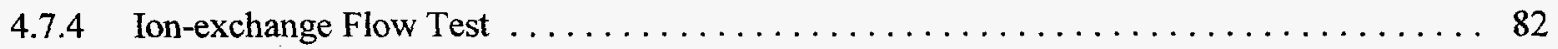

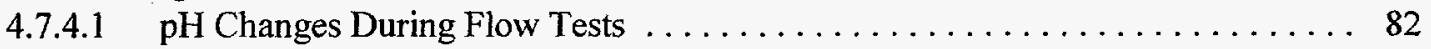

4.7.4.2 Ion-exchange Flow Tests -- Equilibration of the IE-96 Columns $\ldots \ldots \ldots \ldots 82$

4.7.4.3 Conditioning of IE-96 and TIE 96 and Flow-testing with Sludge Wash . . . . 82

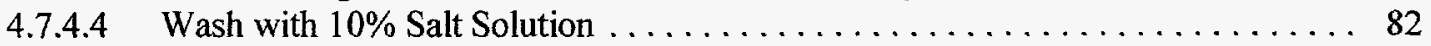


$\underline{\text { Section }}$

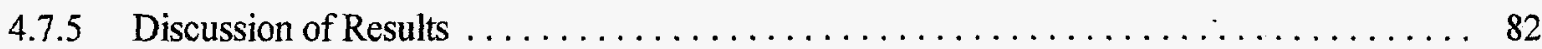

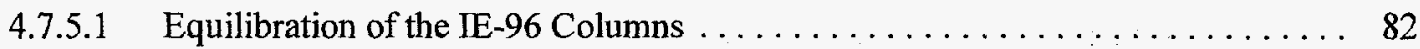

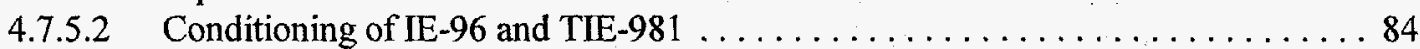

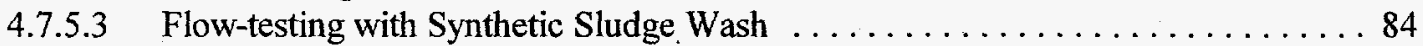

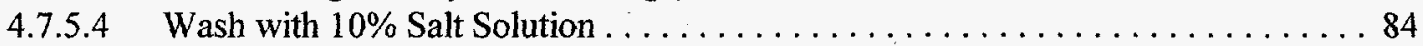

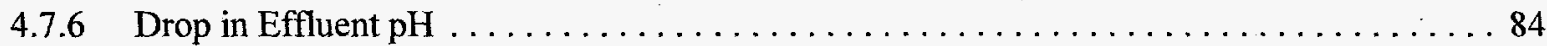

4.8 WVNS-TRQ-071 Zeolite Treatment of THOREX Sludge Wash Solution $\ldots \ldots \ldots \ldots \ldots \ldots$. ${ }^{2}$

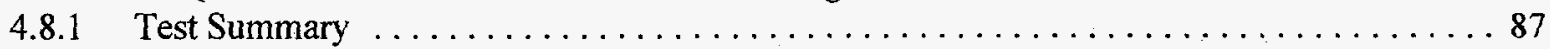

5.0 WVDP SLUDGE WASH AND THOREX WASH PROCESSING $\ldots \ldots \ldots \ldots \ldots \ldots \ldots \ldots$

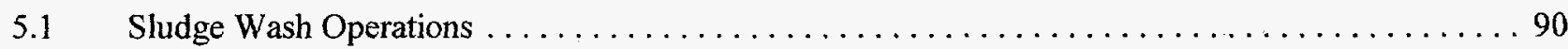

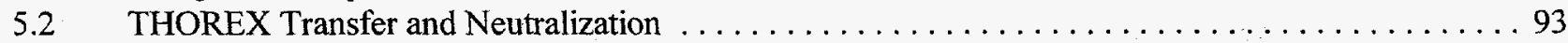

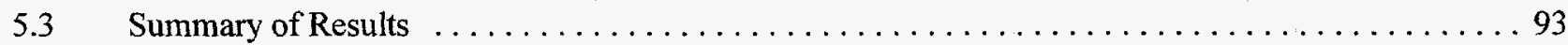

6.0 WVDP FULL-SCALE CAMPAIGN RESULTS $\ldots \ldots \ldots \ldots \ldots \ldots \ldots \ldots \ldots \ldots \ldots \ldots$

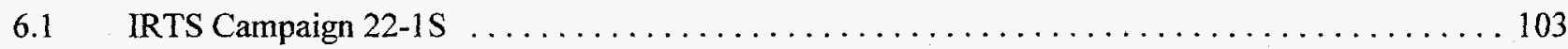

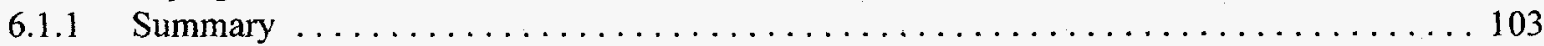

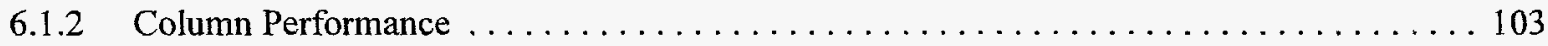

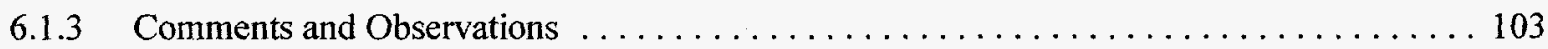

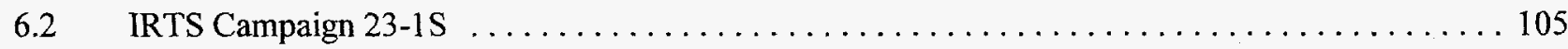

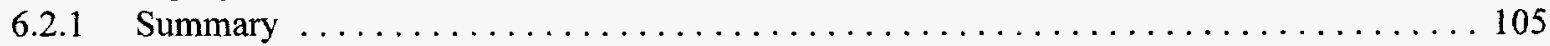

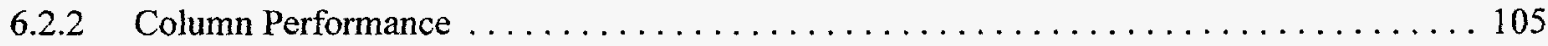

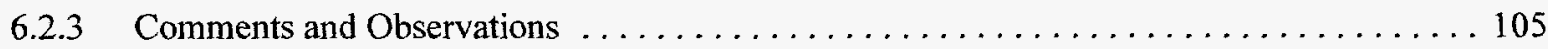

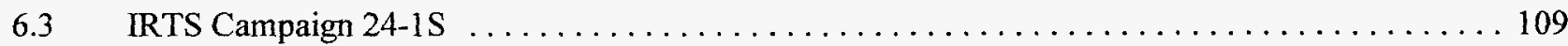

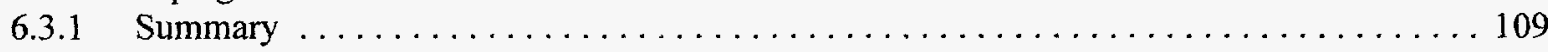

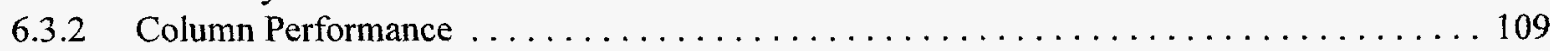

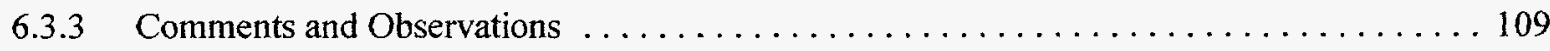

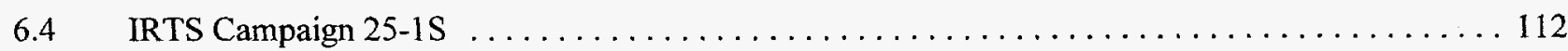

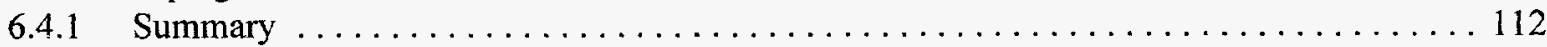

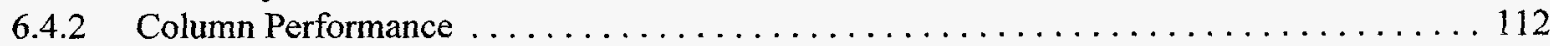

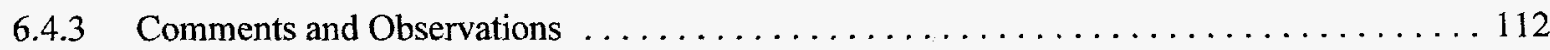

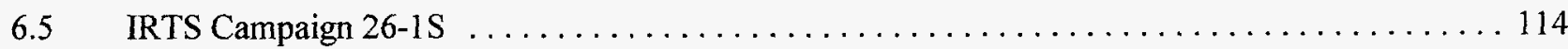

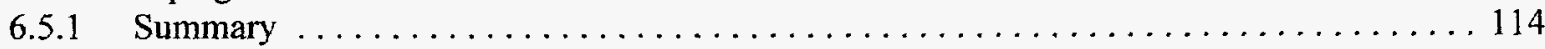

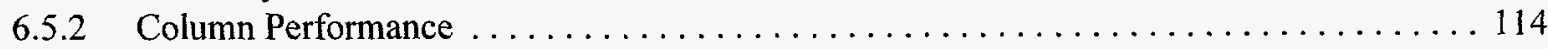

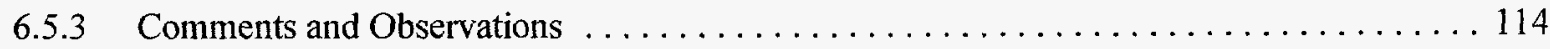

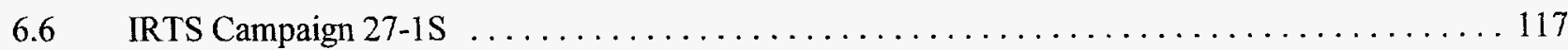

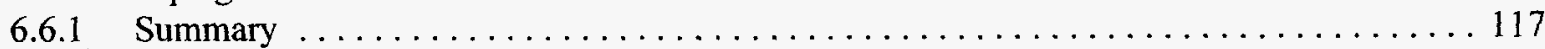

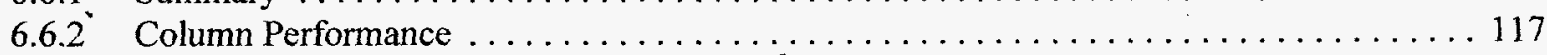

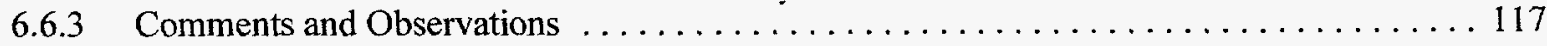




\section{TABLE OF CONTENTS (Continued)}

$\underline{\text { Section }}$

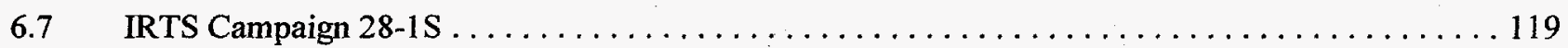

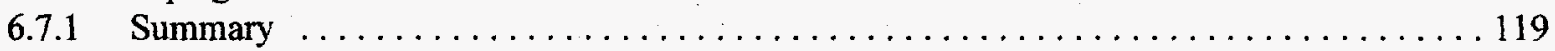

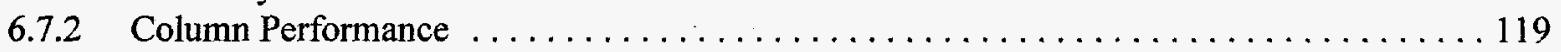

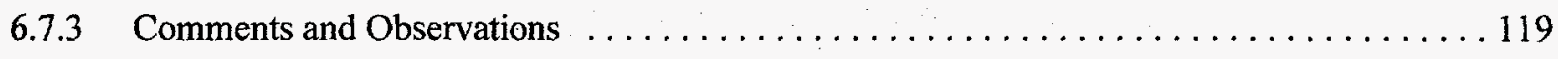

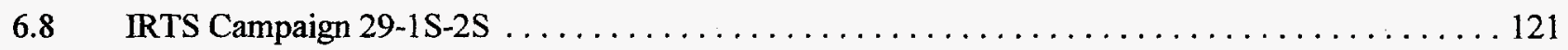

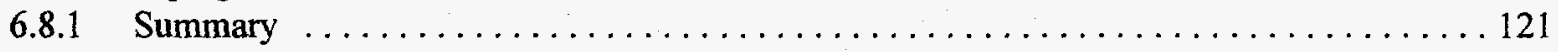

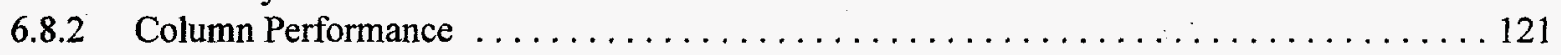

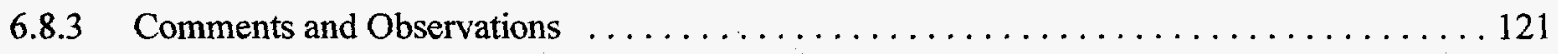

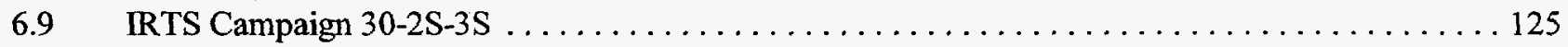

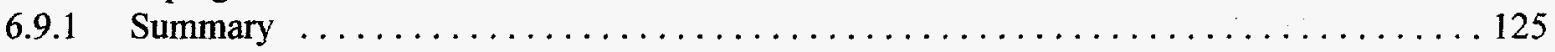

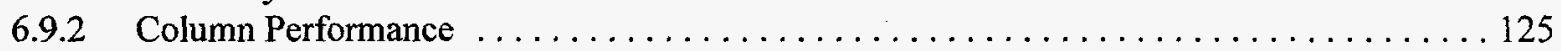

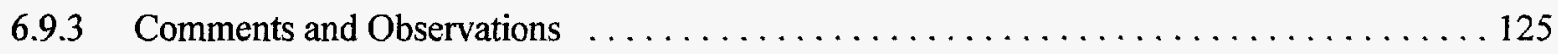

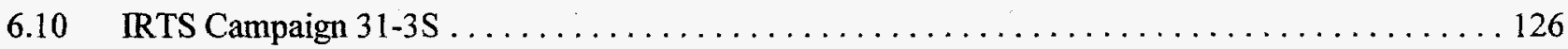

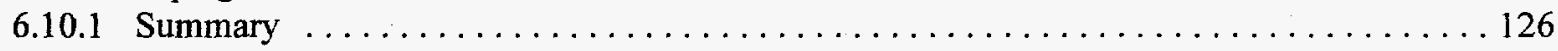

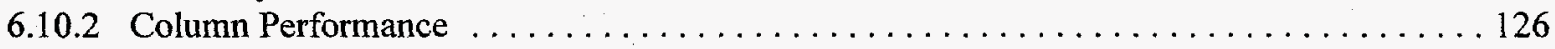

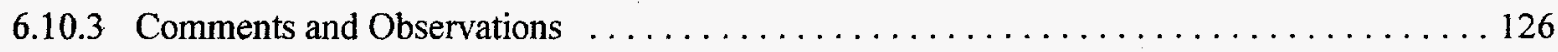

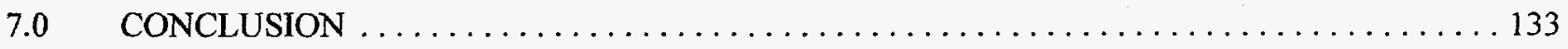

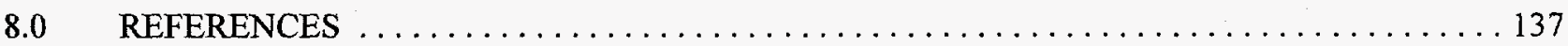




\section{LIST OF FIGURES}

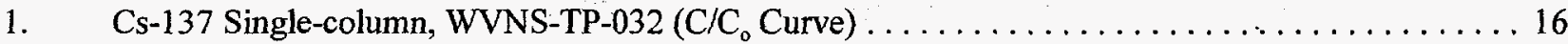

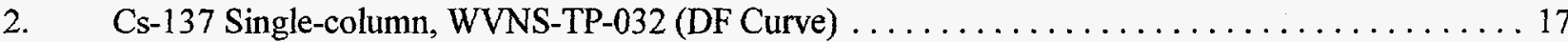

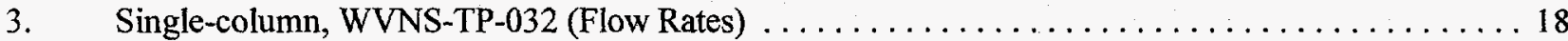

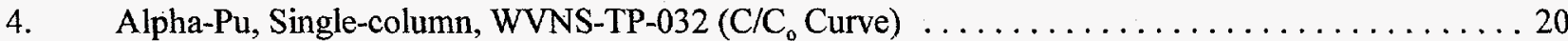

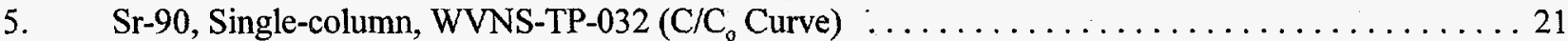

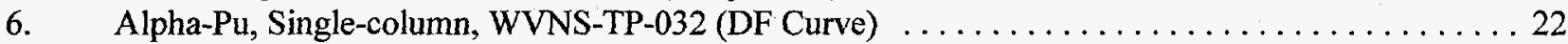

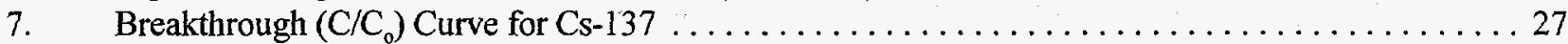

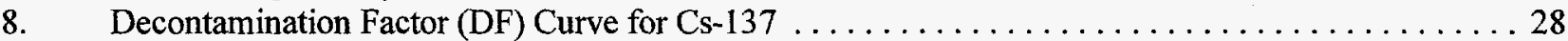

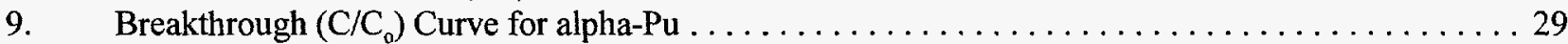

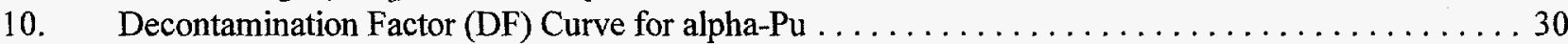

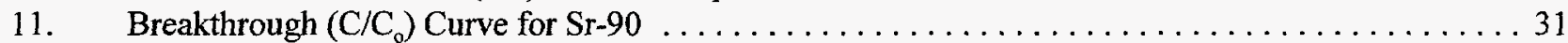

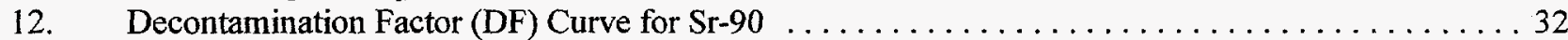

13. Breakthrough $\left(\mathrm{C} / \mathrm{C}_{\mathrm{o}}\right)$ Curve for $\mathrm{Cs}-137$, Different $\mathrm{pHs}$, and Single TIE-96 Column . . . . . . . 38

14. Breakthrough $\left(\mathrm{C} / \mathrm{C}_{\mathrm{o}}\right)$ Curve for alpha-Pu, Different $\mathrm{pHs}$, and Single TIE-96 Column . . . . . . . . 39

15. Breakthrough $\left(\mathrm{C} / \mathrm{C}_{\mathrm{o}}\right)$ Curve for Sr-90, Different $\mathrm{pHs}$, and Single TIE-96 Column . . . . . . . 40

16. Breakthrough $\left(\mathrm{C} / \mathrm{C}_{\mathrm{o}}\right)$ Curve for $\mathrm{Cs}-137$, Temperature Effects, and Single IE-96 and TIE-96

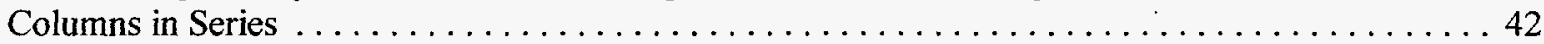

17. Breakthrough $\left(\mathrm{C} / \mathrm{C}_{0}\right)$ Curve for alpha-Pu Temperature Effects, Single IE-96 and TIE-96

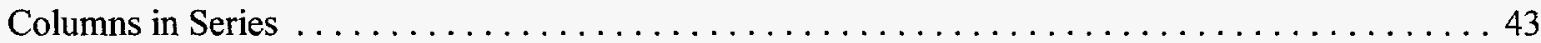

18. Breakthrough $\left(\mathrm{C} / \mathrm{C}_{\mathrm{o}}\right)$ Curve for Sr-90 Temperature Effects, Single IE-96 and TIE-96

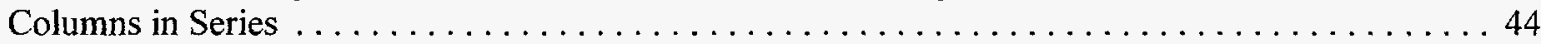

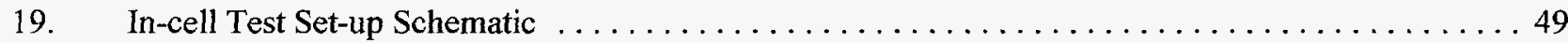

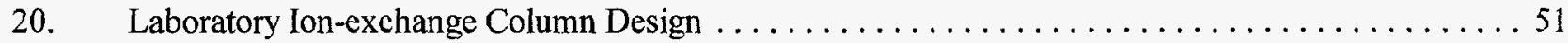

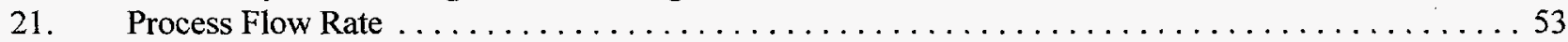

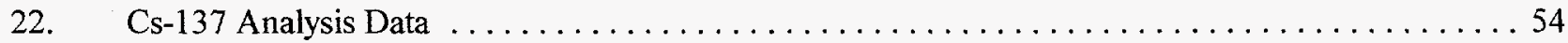

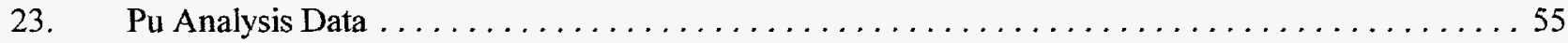

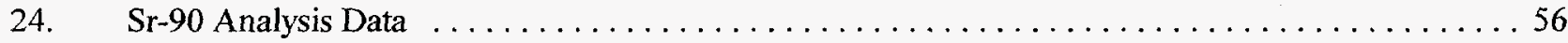

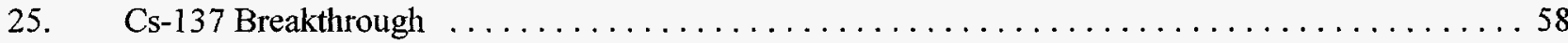

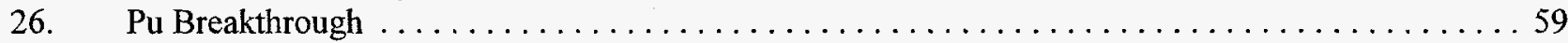

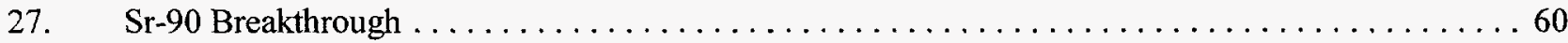

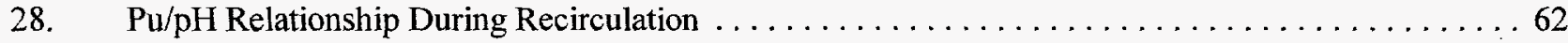

29. $\mathrm{Pu} / \mathrm{pH}$ Relationship During Recirculation and Sludge Washing $\ldots \ldots \ldots \ldots \ldots \ldots \ldots \ldots \ldots$

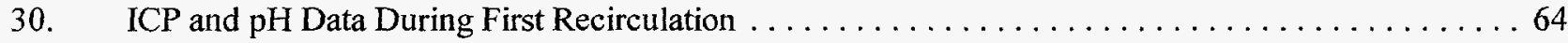

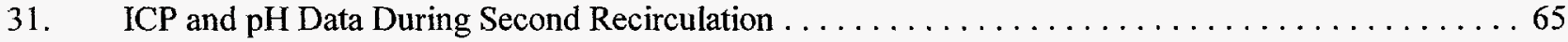

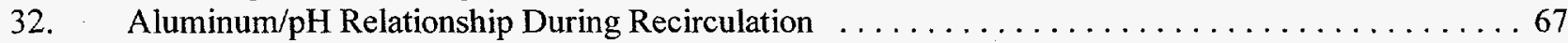

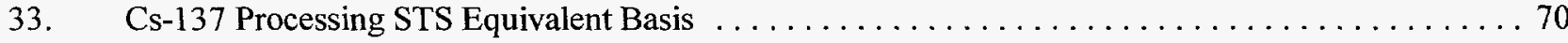

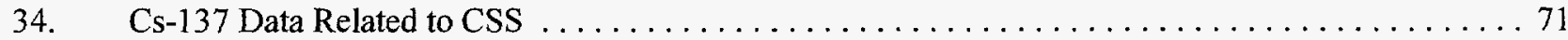

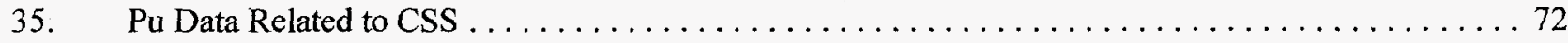

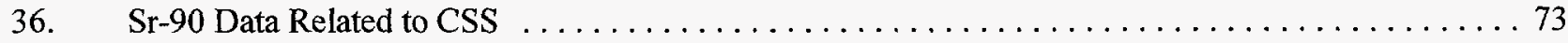

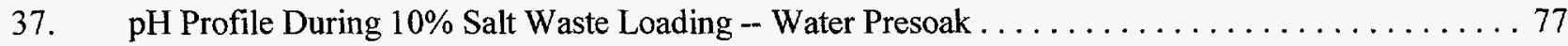

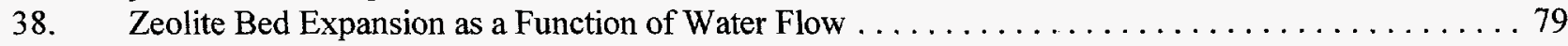

39. High-pH Tests, pH Profile During $10 \%$ Salt Waste Processing $\ldots \ldots \ldots \ldots \ldots \ldots \ldots \ldots \ldots \ldots \ldots$

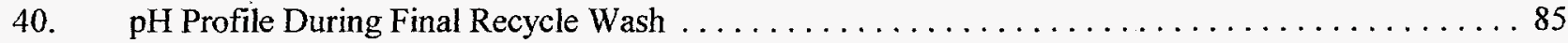

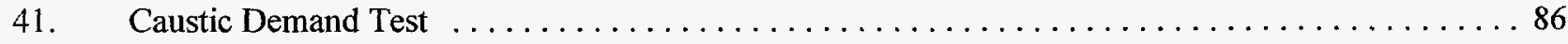

42. STS Zeolite Column Performance Sludge Wash One Campaigns' Cs-137 . . . . . . . . . 97 
43. STS Zeolite Column Performance Sludge Wash Two and THOREX Wash

. Campaigns' Cs-137 ...................................... 98

44. STS Zeolite Column Performance Sludge Wash One Campaigns' alpha-Pu . . . . . . . . . . . 99

45. STS Zeolite Column Performance Sludge Wash Two and THOREX Wash Campaigns' alpha-Pu . . . . . . . . . . . . . . . . . . . . . . . . . . 100

46. STS Zeolite Column Performance Sludge Wash One Campaigns' Sr-90 . . . . . . . . . . 101

47. STS Zeolite Column Performance Sludge Wash Two and THOREX Wash Campaigns' Sr-90 


\section{LIST OF TABLES}

Table

Page

1. WVNS TRQ/TP-023 Zeolite Samples Evaluated $\ldots \ldots \ldots \ldots \ldots \ldots \ldots \ldots \ldots \ldots \ldots \ldots \ldots$

2. WVNS TRQ/TP-023 Results of $\mathrm{R}_{\mathrm{d}}$ "Batch Distribution" of UOP Samples $\ldots \ldots \ldots \ldots \ldots \ldots \ldots .9$

3. WVNS TRQ/TP-023 Results of Single-column Testing using Tank 8D-2 Supernatant

Solution, pH-adjusted and Diluted $1: 1$ with Demineralized Water. . . . . . . . . . . . . . 10

4. WVNS TRQ/TP-023 Results of Single-column Testing with WVNS-1, Sludge Wash

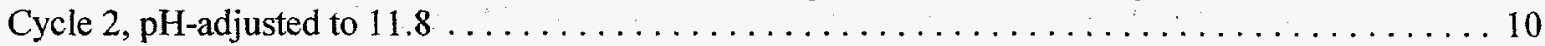

5. WVNS TRQ/TP-033 Tank 8D-2 Supernatant Analyses used in Rd "Batch Distribution"

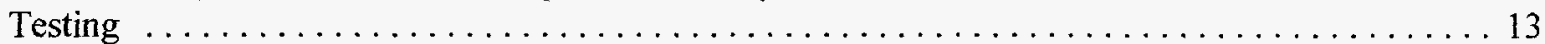

6. WVNS TRQ/TP-033 Results of $R_{d}$ "Batch Distribution" of UOP Samples $\ldots \ldots \ldots \ldots \ldots \ldots \ldots 14$

7. WVNS TRQ/TP-033 Sludge Wash Analysis: WVNS-TP-032, Wash Cycle $1 \ldots \ldots \ldots \ldots \ldots \ldots$

8. WVNS TRQ/TP-033 Summary of the Cs-137 Capacity of the Column-tested Zeolites . . . . . . . . . 19

9. WVNS TRQ/TP-033 Summary of the Results of Single-column Testing with

WVNS TP-032 Wash Cycle 1 , Diluted $1: 1, \mathrm{pH}$ of $12.0: \ldots \ldots \ldots \ldots \ldots \ldots \ldots \ldots \ldots$

10. WVNS TRQ/TP-033 Summary of Estimated Losses from the Titanium-treated Zeolite

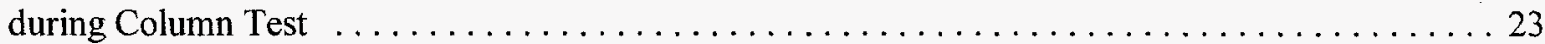

11. WVNS TRQ/TP-037A Sludge Wash Analysis: WVNS-TP-036 Sludge Wash $1 \ldots \ldots \ldots \ldots \ldots 25$

12. WVNS TP-037B Part 1 Column-test Feed Solutions, WVNS-TP-039 Wash Cycle 1

Diluted $1: 1$ with Demineralized Water. . . . . . . . . . . . . . . . . . . . . . . 35

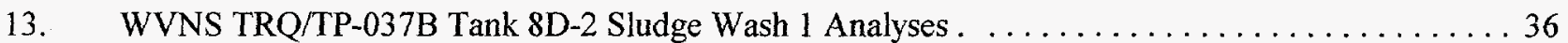

14. Summary of Decontamination Factors for TSR-037B Part 1 Single TIE-96 Zeolite Columns

Tests with Laboratory-prepared Tank 8D-2 Sludge Wash Cycle 1, Diluted $1: 1 \ldots \ldots \ldots \ldots$

15. Summary of Decontamination Factors for TSR-037B Part 2 Tank 8D-2 Sludge Wash Cycle 1,

Diluted 1:1, with Single IE-96 and TIE-96 Zeolite Columns in Series $\ldots \ldots \ldots \ldots \ldots \ldots \ldots \ldots 45$

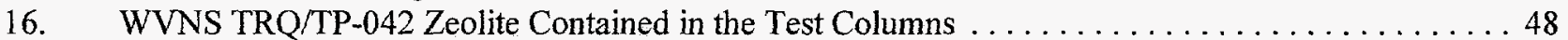

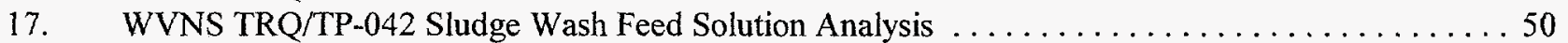

18. WVNS TRQ/TP-042 Recirculating Solution Feed Composition $\ldots \ldots \ldots \ldots \ldots \ldots \ldots \ldots \ldots \ldots . \ldots \ldots$

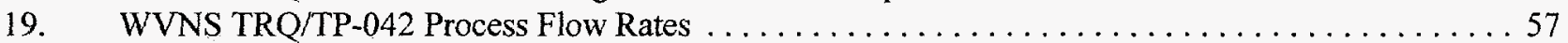

20. WVNS TRQ/TP-042 Recirculating Solution $\mathrm{pH}$ Drop $\ldots \ldots \ldots \ldots \ldots \ldots \ldots \ldots \ldots \ldots \ldots \ldots$

21. WVNS TRQ/TP-042 Comparison of Recirculating Feed and Effluent Composition ........66 66

22. WVNS TRQ/TP-042 Radionuclide Dissolution During First Recirculation $\ldots \ldots \ldots \ldots \ldots \ldots$

23. Synthetic Sludge Wash Solution Components, 10\% Salt Waste Makeup for High-pH Testing . . . . 75

24. Synthetic Sludge Wash Solution Species, 10\% Salt Waste Makeup for High-pH Testing . . . . . . . 76

25. Analysis of White Precipitate -- High-pH Ion-exchange Tests $\ldots \ldots \ldots \ldots \ldots \ldots \ldots \ldots \ldots \ldots 78$

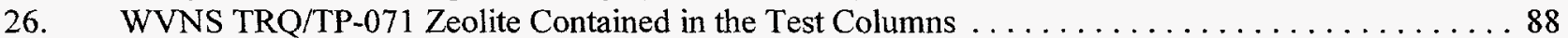

27. WVNS TRQ/TP-071 THOREX Wash Feed Solution Analysis $\ldots \ldots \ldots \ldots \ldots \ldots \ldots \ldots \ldots$

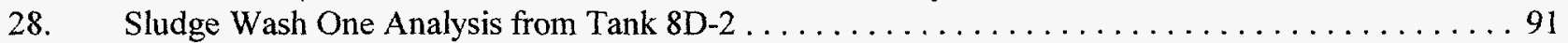

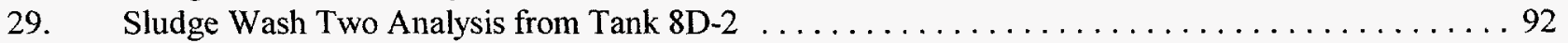

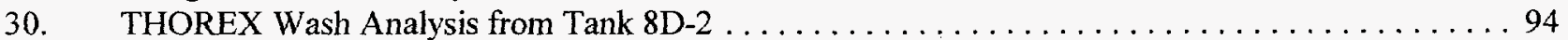

31. Summary of Campaign Results During Sludge Wash and THOREX Wash Processing . . . . . . 95

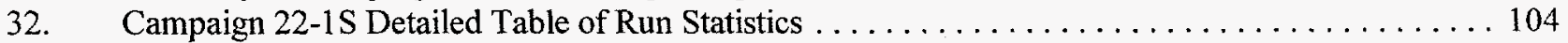

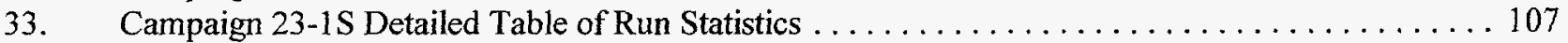

34. Campaign 24-1S Detailed Table of Run Statistics $\ldots \ldots \ldots \ldots \ldots \ldots \ldots \ldots \ldots \ldots \ldots \ldots \ldots$

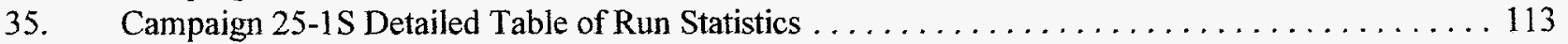

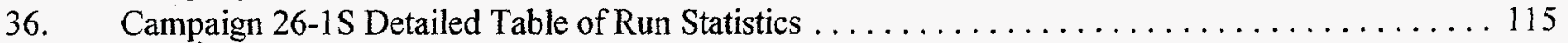

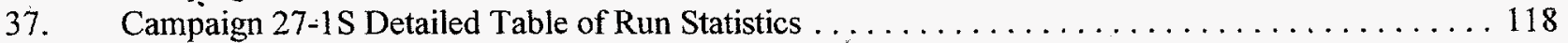


38. Campaign 28-1S Detailed Table of Run Statistics $\ldots \ldots \ldots \ldots \ldots \ldots \ldots \ldots \ldots \ldots \ldots \ldots \ldots$

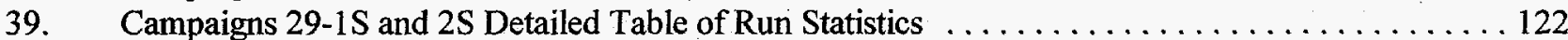

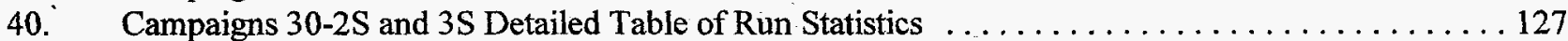

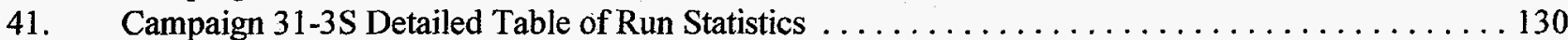

42. Chemical and Physical Comparison of TIE-96 and IE-96 Zeolite $\ldots \ldots \ldots \ldots \ldots \ldots \ldots \ldots \ldots$

43. Comparison of Undiluted Sludge Wash Solutions Processed through TIE-96

Zeolite Columns . . . . . . . . . . . . . . . . . . . . . . . . . . . . . . . . . . . 136 


\section{ACKNOWLEDGMENT}

This report is a historical document tracing the development, scale-up, and qualification of the titaniumtreated Zeolite for use in the Supernatant Treatment System. As an historical document, it relied heavily upon previously generated documents. Some of the people and organizations who contributed testing, data, and reports were:

\section{Pacific Northwest Laboratories}

L. A. Bray

A\&PC Laboratories

W. J. Connors

F. T. Hara

T. F. Kazmierczak

J. L. Mahoney

$\underline{\text { IRTS Engineering }}$

D. E. Carl

D. C. Meess

OTS Engineering
A. J. Howell
G. A. Smith
C. F. Ross 


\section{EXECUTIVE SUMMARY}

Titanium-treated zeolite is a new ion-exchange material that is a variation of UOP (formerly Union Carbide) IONSIV IE-96 zeolite (IE-96) that has been treated with an aqueous titanium solution in a proprietary process. IE-96 zeolite, without the titanium treatment, has been used since 1988 in the West Valley Demonstration Project's (WVDP) Supernatant Treatment System (STS) ion-exchange columns to remove Cs-137 from the liquid supernatant solution. The titanium-treated zeolite (TIE-96) was developed by Battelle-Pacific Northwest Laboratory (PNL). Following successful lab-scale testing of the PNL-prepared TIE-96, UOP was selected as a commercial supplier of the TIE-96 zeolite.

Extensive laboratory tests conducted by both the WVDP and PNL indicate that the TIE-96 will successfully remove comparable quantities of Cs-137 from Tank 8D-2 high-level radioactive liquid as was done previously with IE-96. In addition to removing Cs-137, TIE-96 also removes trace quantities of $\mathrm{Pu}$, as well as $\mathrm{St}-90$, from the liquid being processed over a wide range of operating conditions: temperature, $\mathrm{pH}$, and dilution. The exact mechanism responsible for the Pu removal is not fully understood. However, the Pu that is removed by the TIE-96 remains on the ion-exchange column under anticipated sludge wash processing conditions.

From May 1988 to November 1990, the WVDP processed 560,000 gallons of liquid high-level radioactive supernatant waste stored in Tank $8 \mathrm{D}-2$. Supernatant is an aqueous salt solution comprised primarily of soluble sodium salts. The second stage of the high-level waste treatment process began November 1991 with the initiation of sludge washing. Sludge washing involves the mixing of Tank 8D-2 contents, both sludge and liquid, to dissolve the sulfate salts present in the sludge. This mixing was performed with the addition of approximately 80,000 gallons of demineralized water to further aid in the dissolution of sulfate salts from the sludge during the washing process. Two sludge washes were required to remove sulfates from the sludge. The sludge wash solutions were processed through the WVDP Integrated Radwaste Treatment System (IRTS) in much the same way as the Tank $8 \mathrm{D}-2$ supernatant was previously processed.

The WVDP developed a two-fold approach to address the increased solubility of $\mathrm{U}$ and $\mathrm{Pu}$ anticipated during the sludge washing process:

First, minimize the Pu and $\mathrm{U}$ concentration in the Tank 8D-2 liquid by the adjustment of supernatant chemistry. The $\mathrm{Pu}$ and $\mathrm{U}$ concentrations in the Tank 8D-2 liquid were minimized by adding sodium hydroxide $(\mathrm{NaOH})$ to increase the $\mathrm{pH}$ from its previous value of approximately 10 to a range of 11.8 to 12.5 . Controlling the $\mathrm{pH}$ of sludge wash water reduces the stability of the $\mathrm{Pu}$ and $\mathrm{U}$ compounds.

Second, remove Cs-137, Sr-90, as well as trace quantities of Pu, in the STS ion-exchange columns using TIE96. The high $\mathrm{pH}$ solutions ( $\mathrm{pH} 11.8-12.5$ ) that were planned for sludge wash processing will not degrade, fuse together, or plug the IE-96 or TIE-96 zeolite in the ion-exchange columns. The titanium associated with the TIE-96 will not separate from the zeolite nor flush from the ion-exchange column during operating conditions. In fact, the titanium treatment appears to enhance the attrition resistance of the zeolite particles.

Both of these technologies are compatible with equipment and chemistry of the WVDP's existing IRTS and eventual vitrification process. 
The primary requirements imposed on the new ion-exchange material were to:

(a) Maintain the previous STS ion-exchange decontamination factor of 1,000 for Cs-137 removal.

(b) Remove sufficient soluble Pu from the STS liquid to prevent the resulting cement waste from being classified as transuranic waste and minimize the potential of $\mathrm{Pu}$ precipitation in the Liquid Waste Treatment System (LWTS) evaporator during concentration.

(c) Ensure compatibility with the eventual borosilicate glass waste-form in which the zeolite will reside.

(d) Minimize modifications to existing and proven plant equipment and procedures.

The use of TIE-96 has met all of the technical requirements shown above and has produced a cement wasteform an order of magnitude below the 10CFR61 limit of 100 nanocuries per gram of transuranic nuclides. The titanium content of the zeolite is compatible with the borosilicate glass recipe because titanium is one of the chemicals that will be added to the melter feed.

Laboratory qualification testing has demonstrated that TIE-96 is effective in the removal of Cs-137, $\mathrm{Pu}$, and Sr-90 from the Tank 8D-2 alkaline sludge wash solutions. A vigorous TIE-96 product development program recommended by the West Valley Nuclear Services Company, Inc. (WVNS), provided commercial quantities of this product required for full-scale Tank 8D-2 sludge wash processing.

The combination of $\mathrm{pH}$ control of the sludge wash solutions and the use of TIE-96 ion-exchange media in the IRTS Supernatant Treatment System has been demonstrated both in the laboratory and in full-scale operations. Full-scale use in the STS has been completed with over 1 million gallons of sludge wash solution decontaminated. 


\section{ACRONYMS (continued)}

\section{ACRONYMS}

\section{Meaning}

\begin{tabular}{|c|c|}
\hline $\mathrm{A} \& \mathrm{PC}$ & Analytical and Process Chemistry \\
\hline CSS & Cement Solidification System \\
\hline $\mathrm{CV}$ & Column Volumes \\
\hline CV/HR & Column Volume(s) / Hour \\
\hline DF & Decontamination Factor \\
\hline DOE & Department of Energy \\
\hline G\&H & Sample Identifiers \\
\hline HLW & High-level Radioactive Waste \\
\hline ICP & Induction Coupled Plasma (analytical technique) \\
\hline IRTS & Integrated Radwaste Treatment System \\
\hline LLRW & Low-level Radioactive Waste \\
\hline LLW & Low-level Waste \\
\hline LOI & Loss On Ignition \\
\hline LWTS & Liquid Waste Treatment System \\
\hline NFS & Nuclear Fuel Services Company, Incorporated \\
\hline PNL & Battelle-Pacific Northwest Laboratory \\
\hline PUREX & Plutonium Uranium Reduction Extraction \\
\hline SFCM & Slurry Fed Ceramic Melter \\
\hline STS & Supernatant Treatment System \\
\hline $\mathrm{T} / \mathrm{C}$ & Thermocouple \\
\hline TDS & Total Dissolved Solids \\
\hline TDS & Total Dissolved Solids \\
\hline TIC & Total Incorganic Carbon \\
\hline TOC & Total Organic Carbon \\
\hline
\end{tabular}


TR

TRQs

TS

TSRs

UOP

WVDP

WVNS
Technical Requirement

Test Requests

Total Solids

Test Summary Reports

Manufacturer of IE-96 and TIE-96 Zeolite

West Valley Demonstration Project

West Valley Nuclear Services Company, Incorporated 


\subsection{BACKGROUND}

The West Valley Demonstration Project Act of October 1, 1980 (Public Law 96-368) directs the Department of Energy (DOE) to carry out a high-level radioactive waste (HLW) management demonstration project at the former Western New York Nuclear Services Center site located in West Valley, NY. Under the Act, the DOE is responsible, among other things, for removing the liquid HLW from underground storage tanks and solidifying it into a form suitable for long-term storage and transportation to a federal repository for final disposal. The facility at West Valley, NY was formerly operated by Nuclear Fuel Services, Inc. (NFS) as a commercial nuclear fuel reprocessing plant. West Valley Nuclear Services Co., Inc. (WVNS), a subsidiary of Westinghouse Electric Corporation, was selected to be the prime contractor for site operations, and initiated operations at the site February 1982.

The West Valley site was the location of the only operating commercial nuclear fuel reprocessing plant in the United States. NFS operated this facility from 1966 to 1972, processing 640 metric tons of commercial and defense fuels using the PUREX (plutonium uranium reduction extraction) process. Approximately 2.1 million liters of fuel reprocessing waste resulted from this operation. The major portion ( $\sim 98$ percent by volume) of these wastes were stored in an underground storage tank, designated 8D-2. The bulk of the tank's contents was formed by adding excess caustic $(\mathrm{NaOH})$ to a nitric acid-based stream originating from essentially the first solvent extraction cycle. The neutralization of the solution resulted in the formation of a sludge layer at the bottom of the waste tank, consisting of insoluble oxides, hydroxides, and carbonates at a pH of 10 . A second tank, designated 8D-4, contained about 50,000 liters of nitric acid solution waste remaining from a mixed thorium and uranium fuel reprocessing operation. Tank 8D-4 contents are hereafter referred to as THOREX waste.

The WVDP started processing supernatant from Tank 8D-2 in 1988. Supernatant processing takes place in the Integrated Radwaste Treatment System (IRTS), which consists of four separate processing facilities: the Supernatant Treatment System (STS), Liquid Waste Treatment System (LWTS), Cement Solidification System (CSS), and Drum Cell. In the STS, supernatant is run through a series of ion-exchange columns where Cs137 is removed. In the LWTS, decontaminated supernatant is evaporated and concentrated to a pre-determined salt concentration. In the CSS, concentrated waste is mixed with cement and admixtures to form a stable waste-form and poured into 71-gallon square drums. The waste drums produced at the CSS are then transported to the Drum Cell where they are stored.

The ion-exchange process that takes place in the STS uses the IONSIV® IE-96 inorganic zeolite ion-exchanger (IE-96). The IE-96 is manufactured by UOP. WVNS selected the IE-96 for Cs-137 recovery because of its high-exchange capacity, decontamination factor (DF) values, and ability to be incorporated with glass-formers and washed sludge to form borosilicate glass.

In 1988, Battelle-Pacific Northwest Laboratory (PNL) washed a sample of the WVDP alkaline sludge from Tank 8D-2 and reported that . $20 \%$ of the Pu was transferred to the water wash. In 1989, the WVDP Analytical Laboratory confirmed this observation. WVNS found that $.23 \%$ of the Pu and $.96 \%$ of the U in the sludge transferred to the liquid phase during washing, due to the high carbonate/bicarbonate and the dilution of the $\mathrm{OH}^{-}$in the $\mathrm{pH} 10$ solution. Additional WVDP and PNL studies showed that washing the sludge with caustic water, adjusted with $\mathrm{NaOH}$ to a $\mathrm{pH}$ of 12.5 , significantly reduced the $\mathrm{U}$ and $\mathrm{Pu}$ content in the liquid phase. However, the $\mathrm{Pu}$ content at $\mathrm{pH} 12$ still represented approximately $5 \%$ of the $\mathrm{Pu}$ in the tank, exceeding the actinide limit in the concrete waste-form of $<100 \mathrm{nCi} / \mathrm{g}$ of waste. ${ }^{1}$

PNL investigated several methods for the removal of actinides, as well as Cs-137, from the Tank 8D-2 alkaline sludge wash solutions. WVDP required that the actinide-removal method selected must: remove sufficient $\mathrm{Pu}$ from the Tank 8D-2 sludge wash solution to meet the Class C Low-level Radioactive Waste (LLRW) limit 
(lower than $<100 \mathrm{nCi} / \mathrm{g}$ ), not affect the STS Cs-137 recovery operation, not necessitate additional processing equipment, not affect WVDP vitrification operation, and must be available by FY1992. IE-96 treated with a titanium solution has been developed by PNL within these constraints for the recovery of Pu, Sr-90, and Cs137 from Tank 8D-2 sludge washes. The commercial production of titanium-treated zeolite (TIE-96) has been developed and successfully transferred to UOP. ${ }^{1}$ 


\subsection{TREATMENT OF THE WVDP SLUDGE}

The second phase in the stabilization of the high-level waste at the WVDP was washing the sludge at the bottom of Tank 8D-2. The remaining supernatant heel in Tank 8D-2 was processed simultaneously with the sludge wash solution. The wash water from the sludge wash was processed in a manner similar to the Tank $8 \mathrm{D}-2$ supernatant. The wash operation was required to remove the high concentration of soluble sulfate salts in the sludge because the solubility of sulfate in the glass produced in the slurry fed ceramic melter (SFCM) is limited to 0.3 weight percent. Any sulfate ion concentration in the feed slurry to the SFCM that exceeds the 0.3 weight percent solubility in the glass will form a molten salt layer on the surface of the melt. This layer will interfere with the melting process and result in unacceptable borosilicate glass. In addition, with high sulfate residual concentration, the amount of sludge that can be put into the glass will be much less than planned. It also would result in a substantial increase in the number of glass logs necessary for solidifying the WVDP's high-level waste.

Sludge washing was completed using two caustic $(20 \% \mathrm{NaOH})$ and water additions to Tank $8 \mathrm{D}-2$. During each of these caustic/water additions, the sludge was mobilized via five newly installed mixing pumps to wash the soluble salts from the sludge. Sludge Wash One processing began April 1992 and was completed May 1994. Sludge Wash Two processing began June 1994 and was completed August 1994.

A pretreatment step began December 1994 at the WVDP. In order to minimize the waste variations in the HLW slurry delivered to the Vitrification Facility, Tank 8D-4 THOREX waste and Tank 8D-2 PUREX waste were combined. The direct addition of Tank 8D-4 THOREX waste into high-pH Tank 8D-2 was the process method selected to combine the two wastes. Caustic solution and water were added to Tank 8D-2 prior to the addition of the THOREX waste. The resulting elevated solution $\mathrm{pH}$ ensured the rapid neutralization of the acidic THOREX waste and maintained trace levels of $\mathrm{U}, \mathrm{Sr}-90$, and $\mathrm{Pu}$ in the resulting THOREX wash solution. The combined waste was mixed in Tank 8D-2 using the existing mobilization pumps that were used for sludge wash operations. The resulting THOREX wash solution was treated in the Integrated Radwaste Treatment System (IRTS) as was done with the previous supernatant and sludge wash solutions. THOREX wash processing begun January 1995 and was completed May 1995. 


\subsection{TITANIUM-TREATED ZEOLITE HISTORY}

The use of titanium compounds to decontaminate radioactive aqueous solutions is well documented in chemical literature. Although the primary function of titanates is to remove Sr-90 from high-level wastes, researchers also have noted that these compounds are very efficient at removing specific actinides. ${ }^{2}$

In 1990, researchers at Battelle's Pacific National Laboratory (PNL) developed an improved method to load a titanium compound onto commercially available IE-96 zeolite (PNL Invention Report Number E-882) ${ }^{2}$. This initiated the development described within this report and facilitated the scale-up from laboratory to commercial production scale of a product that can remove $\mathrm{Pu}, \mathrm{Cs}-137$, and $\mathrm{Sr}-90$ from liquid alkaline waste streams.

UOP, the manufacturer of zeolite products, has successfully accomplished the scale-up of the titanium-loading method in their manufacturing facility.

The WVDP is the first location to use the TIE-96 zeolite for full-scale treatment. 


\subsection{TITANIUM-TREATED ZEOLITE LABORATORY TESTING}

Preliminary laboratory ion-exchange column testing at PNL and WVDP during 1990 demonstrated the effectiveness of the titanium-treated zeolite prepared by $\mathrm{PNL}$ to remove $\mathrm{Cs}-137$, alpha-Pu; and $\mathrm{Sr}-90$ radionuclides from a liquid waste stream. ${ }^{3}$

In late 1990, WVNS approached UOP (the manufacturer of zeolite products) to evaluate the possibility of commercial production of the TIE-96. UOP concurred that the manufacturing process and product were viable. In early 1991, UOP started to generate process information and evaluate modifications to the treatment process developed by PNL to allow for processing in UOP's manufacturing facilities. UOP provided WVNS with TIE-96 samples for evaluation and acceptance. WVNS then initiated the procurement and commercial development of the titanium-treated zeolite and qualification of this product for processing Tank 8D-2 sludge wash.

WVNS prepared a test plan (TPL) to document the required testing to qualify the TIE-96 samples supplied and material purchased from UOP. This test plan, "Test Plan for the Qualification of Titanium-treated Zeolite for the Processing of Sludge Wash Liquid" (WVNS-TPL-50-003), documents all of the test conditions and tests completed through April 1992 with the TIE-96 provided by UOP. ${ }^{4}$ All testing at WVDP was initiated by test requests (TRQs) and summarized with the issuance of test summary reports (TSRs) that provided the results of the corresponding tests. The purpose of a TSR is to review and summarize test conditions and results, and relate these results to the STS sludge wash processing plans.

Note that various sludge wash solutions were employed during the titanium-treated zeolite tests described below. Solutions used included:

- Nonradioactive sludge wash simulant

- Raw supernatant from Tank 8D-2

- $\quad \mathrm{HH}$-adjusted supernatant from Tank 8D-2

- Radioactive sludge wash solution prepared in the Analytical and Process Chemistry (A\&PC) Laboratory using actual sludge samples obtained from Tank 8D-2

- Actual sludge wash solution obtained from Tank 8D-2 near the end of the first sludge wash mixing process

- Radioactive THOREX wash solution prepared in the A\&PC Laboratory.

\section{WVNS-TRQ-023, UOP Sample Qualification Testing}

- These tests demonstrated and validated that the TIE-96 samples prepared by UOP would perform as expected, comparing favorably to previous laboratory experiments at PNL and WVDP.

- Tests also evaluated UOP efforts in scaling up the titanium treatment process and their process operating conditions including drying methods and quantity of titanium solutions used.

- Performance of UOP samples was compared to that of PNL's reference material.

- Sludge wash solutions used in these tests include raw supernatant and $\mathrm{pH}$-adjusted supernatant from Tank 8D-2, as well as a radioactive sludge wash solution prepared in the A\&PC Laboratory.

WVNS-TRQ-033, Qualification Testing on 100-lb TIE-96 Order

- This test continued to evaluate UOP scale-up efforts and processing procedures.

- UOP prepared $100 \mathrm{lbs}$ of the TIE-96 in their pilot plant facilities. 
- Laboratory-prepared radioactive sludge wash solutions were used to test small-scale zeolite columns.

- Performance of UOP samples was compared to that of PNL's reference material.

\section{WVNS-TRQ-037. Defining Operating Parameters for STS with TIE-96}

: Laboratory-scale column testing was performed to evaluate the effects of solution temperature, $\mathrm{pH}$, and dilution ratio.

- Results from this test helped predict the performance of TIE-96 at anticipated operating conditions for STS operations.

\section{TRQ-037A}

- A single column of TIE-96, at 10EC, with laboratory-prepared sludge wash solution was tested.

\section{TRQ-037B Part 1}

- Single columns of TIE-96, at 10EC, with laboratory-prepared sludge wash solutions were tested: one column test with $\mathrm{pH} 11.6$ solution and one column test with $\mathrm{pH} 12.0$ solution.

\section{TRQ-037B Part 2}

- A single IE-96 column followed in series by a single TIE-96 column was used with actual Tank 8D-2 sludge wash solution.

- Testing was conducted at solution temperatures of $10^{\circ} \mathrm{C}$ and $26^{\circ} \mathrm{C}$.

\section{WVNS-TRO-042, Column-loading Verification for STS with TIE-96}

- Using laboratory-prepared sludge wash solutions, the performance of two IE-96 columns in series with a single TIE-96 column (anticipated column alignment during STS resumption) was evaluated.

- Columns were run in a recirculation mode to simulate pauses between STS campaigns.

- The lead IE-96 column was taken offline after Cs-137 breakthrough, and the other two columns were moved up in sequence. A fresh IE-96 column was added in the tail position.

\section{Caustic Effects on Ion-exchange IE-96 and TIE-96 Zeolite}

- The effects of high $\mathrm{pH}$ solutions anticipated during sludge wash processing were evaluated and it was determined that the IE-96 and TIE-96 would not degrade or fuse. Cold (nonradioactive) simulated sludge wash solutions were used as column feed.

\section{WVNS -TRQ-071, Zeolite Treatment of THOREX Sludge Wash Solution}

- Laboratory-scale column test to verify effective Cs-137, Pu, and Sr-90 removal by TIE-96 and IE-96 columns in series that reflected anticipated operation of STS during THOREX wash processing. 
Absolute comparisons of each test performed with the different TIE- 96 materials cannot be made because of different solutions and conditions used during testing. However, relative comparisons to previous testing continues to demonstrate that the TIE-96 is an effective material in the removal of Cs-137, alpha-Pu, and Sr-90 radionuclides from a liquid waste stream over the range of processing conditions anticipated during sludge wash processing.

This test program was not able to identify a quick test to evaluate the titanium-treated zeolite for Pu removal and to correlate these results to column performance as in the case with Cs-137 $R_{d}$ "Batch Distribution" for IE96 zeolite. The $R_{d}$ "Batch Distribution" test is a method that has been used to study the decontamination of a specific radionuclide from a solution by cation-selective ion-exchange. $R_{d}$ is defined: $R_{d}=C_{s} / C_{l}$ in ml/g where, $C_{s}=$ concentration of the radionuclide adsorbed on the solid phase ( $g / g$ of zeolite solid) and $C_{1}=$ concentration of the radionuclide remaining in the liquid phase $(\mathrm{g} / \mathrm{ml}$ of solution).

For media such as zeolite, batch distribution measures the ability of zeolite to remove a specific radionuclide of interest from solution. A batch distribution test involves contacting a sample of test solution containing a specific radionuclide of interest with a small weighed sample of zeolite material. After a defined period of time when equilibrium has been reached, a "relative distribution" $R_{d}$ is determined. This test methodology did not work with $\mathrm{Pu}$. It appears that with $\mathrm{Pu}$ removal, as it is implemented at the WVDP, is a rate-controlled reaction; whereas with $\mathrm{Cs}-137$, it is at equilibrium.

The most reliable measure of TIE-96 effectiveness in the removal of $\mathrm{Pu}$ is to conduct flow-through column tests with actual Tank 8D-2 sludge wash solutions at conditions anticipated during Supernatant Treatment System (STS) resumption. The key parameter in the column-testing of the TIE-96 is the decontamination factor (DF) of the ion-exchange material at conditions anticipated for STS operation during sludge wash processing. The $\mathrm{DF}$ is defined as the reciprocal of $\mathrm{C} / \mathrm{C}_{\mathrm{o}}$, or the column influent concentration of the radionuclide to the concentration of the radionuclide after passing through the column. All of the radioactive ion-exchange column tests discussed in Section 4 of this report were conducted in the WVDP A\&PC hot cells.

\subsection{WVNS-TSR-023 $R_{\mathrm{d}}$ - "Batch Distribution" and Column-testing of Titanium-coated IE-96 Zeolite Samples Prepared by UOP}

In their process development laboratory and pilot plant, UOP evaluated different processing techniques, including the amount of titanium treatment, drying temperature, and time. WVNS was supplied with eight samples prepared from the different processing techniques for evaluation and acceptance. A list of samples evaluated in this test is provided in Table $1 .^{5}$ UOP TIE-96 samples were compared directly with PNL laboratory-scale prepared reference TIE- 96 .

WVNS-TRQ-023 Test Request (TRQ) was released with the assumption that Tank 8D-2 supernatant, laboratory-filtered through a 0.45 micron cellulose acetate membrane filter, was a valid simulant of sludge wash cycle 1 solution and, therefore, could be used to evaluate the effectiveness of titanium-treated zeolite (TIE-96) in removing Cs-137 and Pu from sludge wash solutions. This assumption was based on the fact that since the start of Tank 8D-2 supernatant processing, the percentage of total dissolved solids (TDS) had decreased from $35 \%$ to $20 \%$; and the solubility of Pu had increased to a level anticipated during sludge wash one. Testing performed with this solution on all titanium-treated materials (both UOP and PNL samples) was inconclusive and established the need for testing with actual sludge wash solution. 
At the time of this test (spring 1991), the amount of ion-exchange column testing that could be done with actual sludge wash solutions was limited by the small quantities of sludge wash solutions remaining from TIE96 scoping tests in 1990 with the PNL reference TIE-96 zeolite and laboratory-prepared sludge wash solutions, WVNS- 1 and WVNS-2. ${ }^{3}$

Table 1. WVNS TRQ/TP-023 Zeolite Samples Evaluated

\begin{tabular}{llccc}
\hline Sample Resin & Sample No. & $\begin{array}{c}\text { Anhydrous } \\
\text { Wt.\%,TiO }\end{array}$ & Production & Size \\
UOP-48A & MD5884-48 & Medium & $1 \mathrm{~kg}$ & Drying Method \\
UOP-53B & MD5884-53 & Medium & $1 \mathrm{~kg}$ & Heated \\
UOP-56C & MD5884-56 & Medium & $1 \mathrm{~kg}$ & Heated \\
UOP-60D & MD5884-60 & Medium & $50 \mathrm{lbs}$ & Heated \\
UOP-62E & MD5884-62 & Medium & $50 \mathrm{lbs}$ & Heated \\
UOP-64F & MD5884-64 & Medium & $1 \mathrm{~kg}$ & Heated \\
UOP-G & MD5884-88A & High & $1 \mathrm{~kg}$ & Heated \\
UOP-H & MD5884-88H & High & $1 \mathrm{~kg}$ & Ambient air \\
PNL TIE-96 & Lot \#081790 & High & $0.25 \mathrm{~kg}$ & Ambient air \\
IE-96 & 939690990001 & Very low &.-- & --- \\
\hline
\end{tabular}

Results from single-column, ion-exchange testing, using a laboratory sludge wash WVNS-1 wash cycle 2 solution and $\mathrm{pH}$-adjusted with $\mathrm{NaOH}$, showed that the PNL TIE-96 with a $\mathrm{TiO}_{2}$ content of $4.9 \%$ had a Pu decontamination factor (DF) approximately five times greater than the UOP sample $\mathrm{F}$ with a $\mathrm{TiO}_{2}$ content of $3.2 \%$. UOP was then instructed to prepare samples with a $\mathrm{TiO}_{2}$ content of 4 to $6 \%$ above the content in the base IE-96 zeolite.

Final column tests were run on the UOP samples, labeled $\mathrm{G} \& \mathrm{H}$, prepared at $5.5 \% \mathrm{TiO}_{2}$. Due to the lack of availability of Tank 8D-2 sludge and sludge wash solutions, the final series of columns tests were run with Tank $8 \mathrm{D}-2$ supernatant, $\mathrm{pH}$-adjusted with $\mathrm{NaOH}$ to 11.8 and diluted $1: 1$ by weight with demineralized water.

The results of this testing have shown that UOP was successful in the implementation of the titanium-treatment process developed by PNL. Direct comparison between UOP samples and PNL TIE-96 showed the UOP material to be acceptable. UOP was able to identify the processing techniques and conditions required to manufacture TIE-96 on a pilot- and production plant-scale. WVNS then released UOP to produce $100 \mathrm{lbs}$ of TIE-96 zeolite in their pilot plant.

\subsubsection{Test Results}

\subsubsection{Batch Distribution}

The Cs-137 $R_{d}$ "Batch Distribution" test results have shown results similar to those achieved during the PNL development of the TIE-96. The Cs- $137 \mathrm{R}_{\mathrm{d}}$ for the titanium-treated zeolite was slightly lower compared to the IE-96 levels. The results, summarized in Table 2, show that the titanium-treated zeolite has a much greater affinity for Pu compared to the normal IE-96. The results from the $R_{d}$ testing on the UOP samples and PNL 
reference TIE-96 have shown that the TIE-96 material removes Pu and Sr-90 greater by at least a factor of 10 as compared to IE-96 zeolite.

Batch distribution testing for Cs-137 indicates good general agreement between the $R_{d}$ and the Cs-137 Decontamination Factors (DFs) obtained from ion-exchange column tests. However, batch distribution testing for $\mathrm{Pu}$ has shown that the $\mathrm{R}_{\mathrm{d}}$ values do not correlate with the Pu DFs obtained from column tests. The $\mathrm{Pu}$ batch distribution $R_{d}$ values do, however, provide a limited usefulness in comparing samples of TIE-96 zeolite from different batches.

The reason for the difference in Cs-137 and Pu batch distribution agreement to column DF test results is thought to be because the $\mathrm{Pu}$ reaction rate is slow. It is not at equilibrium at the conclusion of the $\mathrm{R}_{\mathrm{d}}$ test. In contrast, Cs-137 is in apparent equilibrium in the $\mathrm{R}_{\mathrm{d}}$ test. In addition, the low concentration of $\mathrm{Pu}$ in the feed solution results in an equilibrium $\mathrm{Pu}$ concentration that can approach analytical detection limits. Thus, normal analytical errors in the Pu analysis causes a significant variance in the measured $\mathrm{Pu} \mathrm{R}_{\mathrm{d}}$ value.

\begin{tabular}{lcccc}
\hline \multicolumn{4}{c}{ Table 2. WVNS-TRQ/TP-023 Results of $\mathrm{R}_{\mathrm{d}}$ "Batch Distribution" of UOP Samples } \\
\hline Sample Resin & ${\text { \% } \mathrm{TiO}_{2}}_{2}$ & $\underline{\mathrm{Cs}-137}$ & $\underline{\mathrm{Pu}}$ & $\underline{\mathrm{Sr}-90}$ \\
UOP-48A & Medium & 297 & 109 & 461 \\
UOP-52B & Medium & 33 & 119 & 645 \\
UOP-56C & Medium & 320 & 172 & 560 \\
IE-96 (a) & Very low & 318 & 9 & 74 \\
PNL TIE-96(a) & High & 210 & 209 & 406 \\
UOP-60D & Medium & 351 & 395 & N/A \\
UOP-62E & Medium & 314 & 617 & N/A \\
UOP-64F & Medium & 354 & 249 & N/A \\
IE-96 (b) & Very low & 331 & 13 & N/A \\
PNL TIE-96(b) & High & 242 & 274 & N/A \\
\hline
\end{tabular}

(a) Controls analyzed with UOP Samples A, B, and C

(b) Controls analyzed with UOP Samples D, E, and F

\subsubsection{Column Tests}

The following column tests were performed with the following zeolite samples and test solutions:

\section{$\underline{\mathrm{UOP}-\mathrm{COL} 1 \text { and UOP-COL } 2}$}

Both of these tests have shown that $\mathrm{pH}$-unadjusted Tank $8 \mathrm{D}-2$ supernatant cannot be used as a substitute for Tank 8D-2 sludge wash solutions in ion-exchange column testing to determine Pu decontamination factors (DF). This was shown to be valid for all titanium-treated zeolite samples, prepared both by UOP and PNL. Alpha-Pu DFs were all less than 2 through 100 column volumes (cv). As expected, titanium-treated zeolites did have a slightly lower capacity for Cs-137. All of the titanium-treated zeolites showed low capacity for the removal of $\mathrm{Pu}$ from unadjusted Tank $8 \mathrm{D}-2$ supernatant. Based on these results, column tests 1 and 2 were inconclusive. 


\section{$\underline{\text { UOP-COL } 3 \text { and UOP-COL } 4}$}

The performance of the PNL TIE-96 sample was bounded by the UOP samples G and H. All three samples were effective in the removal of Cs-137 and alpha-Pu from pH-adjusted Tank 8D-2 supernatant. The decontamination factors are summarized in Table 3. The efficiency for Pu removal by the UOP-64F and UOPG compares favorably with PNL TIE-96. The decontamination factors for column tests with WVNS-1 sludge wash cycle 2 feed solution, pH-adjusted to 11.8, are summarized in Table 4.

Table 3. WVNS-TRQ/TP-023

Results of Single-column Testing using Tank 8D-2 Supernatant Solution, pH-adjusted and Diluted 1:1 with Demineralized Water

\section{UOP-COL 4(B)}

\section{Sample Resin}

PNL TIE-96
UOP-G
UOP-H

\begin{tabular}{lccc} 
& \multicolumn{4}{c}{ CS-137 Decontamination Factor } \\
& $\underline{50 \mathrm{cv}}$ & $\underline{100 \mathrm{cv}}$ & $\underline{150 \mathrm{cv}}$ \\
PNL .TIE-96 & 37,000 & 73 & 2 \\
UOP-G & $>50,000$ & 1,900 & 19 \\
UOP-H & 917 & 8 & 1 \\
\hline
\end{tabular}

Table 4. WVNS-TRQ/TP-023

Results of Single-column Testing with WVNS-1, Sludge Wash Cycle 2, pH-adjusted to 11.8

Sample Resin

PNL TIE-96

UOP-64F
alpha-Pu Decontamination Factor

$\begin{array}{cccc}\underline{70 \mathrm{cv}} & \underline{145 \mathrm{cv}} & \frac{180 \mathrm{cv}}{240 \mathrm{cv}} & \frac{243}{>10,000} \\ >10,000 & 1,720 & 310 & 83 \\ >10,000 & 16350 & 420 & 130 \\ & 160 & 90 & 57\end{array}$

\begin{tabular}{lccc} 
Sample Resin & \multicolumn{3}{c}{ alpha-Pu Decontamination Factor } \\
& $\underline{40 \mathrm{cv}}$ & $\frac{70 \mathrm{cv}}{900}$ & $\underline{100 \mathrm{cv}}$ \\
PNL TIE-96 & 4430 & 940 \\
UOP-64F & 1900 & 116 & 55
\end{tabular}

CS-137 Decontamination Factor

\begin{tabular}{lccc} 
& $\underline{40 \mathrm{cv}}$ & $\underline{70 \mathrm{cv}}$ & $\underline{100 \mathrm{cV}}$ \\
PNL TIE-96 & $>10,000$ & $>10,000$ & $>10,000$ \\
UOP-64F & $>10,000$ & $>10,000$ & $>10,000$ \\
\hline
\end{tabular}




\subsubsection{Comment on Pu Removal}

One possible explanation of why Pu removal is low using unadjusted Tank 8D-2 supernatant is the presence of carbonate/bicarbonate species that could react with the $\mathrm{Pu}$ to form soluble $\mathrm{Pu}$ compounds that will not be removed by the TIE-96 zeolite during column tests. The WVNS Analytical and Process Chemistry Laboratory cannot measure the presence of the carbonate/bicarbonate species due to the presence of and interference from the other species in the waste solution. Increasing the $\mathrm{pH}$ from 10 to 12 will convert the bicarbonate to carbonate ion. Another probable explanation for the low Pu removal is the presence of alkaline earth metal ions (calcium, $\mathrm{Sr}-90$, and barium) that could interfere with $\mathrm{Pu}$ removal. When the $\mathrm{pH}$ of the supernatant is increased with sodium hydroxide $(\mathrm{NaOH})$ to 12 from 10 , the solubility of the Pu compounds decrease. Tank 8D-2 supernatant, $\mathrm{pH}$ - adjusted to 12 with $\mathrm{NaOH}$ and diluted to $1: 1$ with demineralized water, was the best available substitute for Tank 8D-2 sludge wash solutions in ion-exchange column testing for Pu decontamination.

\subsubsection{Discussion of Results}

The objective of this test was to evaluate and assist UOP in the transfer and development of the titaniumtreated IE-96. This objective was accomplished. Drying methods, processing techniques, and the amount of titanium treatment required were identified and implemented by UOP. The results of this testing demonstrated that UOP could implement this treatment process. Based on this test, WVNS proceeded to procure additional titanium-treated IE-96. The UOP samples demonstrated a comparable performance to PNL TIE-96 for the removal of Cs-137, alpha-Pu, and Sr-90 from, (1) sludge wash solution from WVNS-1 wash cycle 2 and (2) pH-adjusted Tank 8D-2 supernatant diluted 1:1 by weight with demineralized water. This test series failed to identify a quick test to evaluate the titanium-treated zeolite for Pu removal and failed to correlate these results to column performance as in the case with Cs-137 $R_{d}$ "Batch Distribution" and IE-96 zeolite. The complication encountered during this test is attributed to the test solutions and not the titanium-treated zeolite samples. Unadjusted Tank 8D-2 supernatant cannot be used to evaluate the effectiveness of Pu removal by the titanium-treated zeolite. The most reliable measure of the titanium-treated zeolite effectiveness in the removal of $\mathrm{Pu}$ is column tests with actual Tank 8D-2 sludge wash solutions at conditions anticipated during STS resumption.

\subsection{WVNS-TSR-033 -- Qualification Testing on the 100-lb Pilot-scale TIE-96 Zeolite Prepared by UOP}

In response to the WVNS purchase order, UOP prepared two 50-pound batches of TIE-96 in their pilot plant facility. This represents a significant scale up from previously prepared laboratory batch sizes of two pounds. Qualification testing on TIE-96 zeolite prepared at the pilot plant-scale has shown that UOP was successful in their scale-up efforts to implement the titanium-treatment process of IE-96 zeolite that was developed by PNL. The results of this test have demonstrated that the TIE-96 zeolite will effectively remove Cs-137, alpha-Pu, and Sr-90 from anticipated Tank 8D-2 sludge wash solutions. ${ }^{6}$ This test evaluated the performance of both the PNL-prepared reference TIE-96 and UOP pilot-plant batches of TIE-96. Test results indicated that UOP TIE96 material has a comparable performance to PNL material. Based on these results, UOP was released to scale-up the process from the pilot-plant scale to a small production-scale process and prepare an additional 7,200 lbs of TIE-96; enough for two STS ion-exchange columns. 


\subsubsection{TIE-96 Chemical Analysis}

The WVNS A\&PC Group performed pretesting of TIE-96 material prepared in UOP's pilot plant to assure that the material received complied with the material specifications in WVNS-MA-104. This included measurement of percent titanium, percent moisture, water-leachable ions, and leach solution $\mathrm{pH}$. It should be noted that the chemical analytical methods utilized by UOP to measure chemical species are not the same as those used by the A\&PC Group in the evaluation of UOP pilot-plant batches. UOP's analytical methods depend on the compound analysis requested. A typical UOP analytical method includes acid dissolution followed by either atomic adsorption, emission spectrography, or titration measurement techniques. The procedures used by UOP are fully documented and controlled. UOP procedures have been reviewed and accepted through approval request by WVNS as part of the TIE-96 zeolite procurement. The A\&PC Lab does not use these exact procedures. It is not foreseen that they will be adapted nor is there a need to develop them. Due to the different analytical methods used and the accuracies of these methods, identical results were not anticipated from analyses performed at UOP and WVNS. Comparison of these proprietary results indicates good general agreement and the analyses meet the requirements of WVNS-MA-104.

\subsubsection{Water Soluble Anions}

The total water-leachable chloride ion was determined by leaching a weighed sample of zeolite in a specified weight of demineralized water. An aliquot of the supernatant from the leach solution was removed and analyzed for leachable chloride ion by Ion Chromatography, ACM-IC-1501. These proprietary results were judged to be acceptable.

\subsubsection{Total Elemental Analysis}

A total elemental analysis was performed on the UOP samples, PNL-prepared reference TIE-96 zeolite, and IE-96 zeolite. All samples were first fused according to the ACM-Fusion-3801 procedure, followed by elemental analysis using the Induction Coupled Plasma method of ACM-ICP-1002. The normalized weight percent of the corresponding oxides were calculated from the measured elemental values. The elemental analysis of the TIE-96 zeolite was judged to be acceptable.

\subsection{2 $R_{d}$ - "Batch Distribution"}

Using the $R_{d}$ - "Batch Distribution" test methodology, the WVNS A\&PC Group tested the TIE-96 material from UOP's pilot-plant batches as well as the PNL reference TIE-96 and IE-96 zeolites. The test solution used was Tank 8D-2 supernatant, laboratory-filtered through a 0.45 micron cellulose acetate membrane filter and diluted 1:1 with demineralized water. Analysis of the solution used in the test is provided in Table 5. A summary of the results is provided in Table 6 .

The Cs-137 $\mathrm{R}_{d}$ "Batch Distribution" test results are similar to those achieved during the PNL development of TIE-96 zeolite and earlier laboratory samples prepared by UOP. The Cs- $137 R_{d}$ with TIE-96 was slightly lower compared to IE-96 zeolite levels.

The results for Pu $R_{d}$ - "Batch Distribution" testing on UOP TIE-96 samples, PNL-produced reference TIE-96, and IE-96 have shown that the TIE-96 material has greater apparent removal for Pu than IE-96 zeolite by a factor of 200. As stated earlier, the $R_{d}$ value is an indicator of the Pu removal effectiveness, but is not 
predictive of column performance, as is the case with the Cs-137 $R_{d}$. The $R_{d}$ testing indicated significant batch-to-batch variation on the titanium-treated zeolite.

\subsubsection{Ion-exchange Column Tests}

The key parameter in the qualification of TIE-96 is the decontamination factor (DF) of the ion-exchange material at operating conditions anticipated in the STS during sludge wash processing. Material from UOP's pilot-plant production batches have demonstrated a comparable capacity to the PNL reference TIE-96 for the removal of Cs-137, alpha-Pu, and $\mathrm{Sr}-90$ from sludge wash solution. The sludge wash solution used in this test was prepared as directed in WVNS-TP-032 from laboratory archive samples of sludge collected from Tank 8D-2. ${ }^{7}$ The sludge sample that was washed consisted of a composite sample from the M-2, 3, 4, and 7 risers collected in 1989 and a sample of the hard sludge layer collected from the M-6 riser in 1990. This sludge wash solution was designated as WVNS-TP-032 wash cycle 1 . Due to the limited quantity of solution available, only TIE-96 zeolites were tested in the column tests. The analysis of Test Procedure WVNS-TP-032 wash cycle 1 is provided in Table 7.

\subsubsection{Discussion of the Results}

This test was planned to support manufacturing scale-up of TIE-96 zeolite. The test was also conducted to obtain process information. As it developed, the test also documented process repeatability in a double blind test when two columns from the same UOP lot were tested. The conclusion reached from this test was that UOP and PNL TIE-96 zeolites performed nearly identically. This resulted in the decision to proceed with the manufacturing scale-up of the UOP titanium-treatment process for TIE-96.

Table 5. WVNS-TRQ/TP-033

Tank 8D-2 Supernatant Analyses used in $R_{d}$ "Batch Distribution" Testing

\begin{tabular}{|c|c|c|c|}
\hline Analysis & $\begin{array}{c}\text { Filtered } \\
\text { Supernatant }\end{array}$ & $\begin{array}{l}\text { Supernatant Diluted } \\
\text { 1:1 with Demineralized } \\
\text { Water }\end{array}$ & $\begin{array}{c}\text { Demineralized } \\
\text { Water }\end{array}$ \\
\hline $\mathrm{pH}$ & 9.87 & 10.0 & - \\
\hline Total solids \% (TS) & - & -- & - \\
\hline Density $(\mathrm{gm} / \mathrm{ml})$ & 1.175 & 1.083 & - \\
\hline alpha-Pu $(\mu \mathrm{Ci} / \mathrm{g})$ & 0.114 & 0.0547 & - \\
\hline$U(\mu \mathrm{g} / \mathrm{g})$ & -- & 47 & - \\
\hline $\mathrm{Sr}-90(\mu \mathrm{Ci} / \mathrm{g})$ & 0.580 & 0.282 & - \\
\hline $\mathrm{Cs}-137(\mu \mathrm{Ci} / \mathrm{g})$ & 840 & 411 & - \\
\hline Total Dissolved Solids (TDS) & 22.68 & 11.58 & - \\
\hline$F^{-}(\mu \mathrm{g} / \mathrm{g})$ & $<930$ & -- & $<1$ \\
\hline $\mathrm{Cl}^{-}(\mu \mathrm{g} / \mathrm{g})$ & $<1,900$ & -- & $<2$ \\
\hline $\mathrm{NO}_{2}^{-}(\mu \mathrm{g} / \mathrm{g})$ & 67,000 & - & $<5$ \\
\hline $\mathrm{NO}_{3}^{-}(\mu \mathrm{g} / \mathrm{g})$ & 63,000 & - & $<5$ \\
\hline
\end{tabular}


Table 5. WVNS-TRQ/TP-033 (continued)

Tank 8D-2 Supernatant Analyses used in $R_{d}$ "Batch Distribution" Testing

\begin{tabular}{|c|c|c|c|}
\hline Analysis & $\begin{array}{c}\text { Filtered } \\
\text { Supernatant }\end{array}$ & $\begin{array}{c}\text { Supernatant Diluted } \\
\text { 1:1 with Demineralized } \\
\text { Water }\end{array}$ & $\begin{array}{c}\text { Demineralized } \\
\text { Water }\end{array}$ \\
\hline $\mathrm{SO}_{4}^{-}(\mu \mathrm{g} / \mathrm{g})$ & 11,100 & -- & $<5$ \\
\hline $\mathrm{Ca}(\mu \mathrm{g} / \mathrm{g})$ & 620 & -- & $<10$ \\
\hline $\mathrm{Cr}(\mu \mathrm{g} / \mathrm{g})$ & 240 & - & $<10$ \\
\hline $\mathrm{Fe}(\mu \mathrm{g} / \mathrm{g})$ & $<30$ & - & $<10$ \\
\hline$K(\mu \mathrm{g} / \mathrm{g})$ & 2,100 & -- & $<10$ \\
\hline $\mathrm{Na}(\mu \mathrm{g} / \mathrm{g})$ & 56,400 & - & $<10$ \\
\hline $\mathrm{Ni}(\mu \mathrm{g} / \mathrm{g})$ & $<30$ & -- & $<10$ \\
\hline $\mathrm{Mg}(\mu \mathrm{g} / \mathrm{g})$ & $<30$ & -- & $<10$ \\
\hline
\end{tabular}

Table 6. WVNS-TRQ/TP-033

Results of $R_{d}$ "Batch Distribution" of UOP Samples

\begin{tabular}{lccc}
\hline Sample Resins & Cs-137 & $\underline{\text { Pu }}$ & $\underline{\text { Sr-90 }}$ \\
IE-96 & 126 & 1.75 & - \\
PNL TIE-96 & 116 & 367 & 296 \\
UOP TIE-96 10004(a) & 101 & 414 & 790 \\
UOP TIE-96 10004(b) & 94 & 415 & 770 \\
\hline
\end{tabular}

(a) and (b) are repeated analyses

Table 7. WVNS-TRQ/TP-033

Sludge Wash Analysis: WVNS-TP-032, Wash Cycle 1

\begin{tabular}{lcc}
\hline Analysis & $\begin{array}{c}\text { Undiluted } \\
\text { Wash Solution }\end{array}$ & $\begin{array}{c}\text { Wash Solution Diluted 1:1 } \\
\text { with Demineralized Water } \\
\text { and NaOH Addition }\end{array}$ \\
pH & 9.8 & 12.0 \\
Total solids \% $(\mathrm{TS})$ & 23.3 & 12.2 \\
Density $(\mathrm{gm} / \mathrm{ml})$ & 1.186 & 1.089 \\
Gross alpha $(\mu \mathrm{Ci} / \mathrm{g})$ & - & $<4.4 \mathrm{E}-01$ \\
alpha-Pu $(\mu \mathrm{Ci} / \mathrm{g})$ & 0.115 & 0.051 \\
$\mathrm{U}(\mu \mathrm{g} / \mathrm{g})$ & 52 & - \\
$\mathrm{Sr}-90(\mu \mathrm{Ci} / \mathrm{g})$ & 1.19 & 0.53 \\
\hline
\end{tabular}


Analysis

Cs-137 ( $\mu \mathrm{Ci} / \mathrm{g})$

$\mathrm{F}^{-}(\mu \mathrm{g} / \mathrm{g})$

$\mathrm{Cl}^{-}(\mu \mathrm{g} / \mathrm{g})$

$\mathrm{NO}_{2}^{-}(\mu \mathrm{g} / \mathrm{g})$

$\mathrm{NO}_{3}^{-}(\mu \mathrm{g} / \mathrm{g})$

$\mathrm{SO}_{4}^{-}(\mu \mathrm{g} / \mathrm{g})$

$\mathrm{Al}(\mu \mathrm{g} / \mathrm{g})$

B $(\mu \mathrm{g} / \mathrm{g})$

$\mathrm{Ca}(\mu \mathrm{g} / \mathrm{g})$

$\mathrm{Cr}(\mu \mathrm{g} / \mathrm{g})$

$\mathrm{Fe}(\mu \mathrm{g} / \mathrm{g})$

$\mathrm{K}(\mu \mathrm{g} / \mathrm{g})$

$\mathrm{Mg}(\mu \mathrm{g} / \mathrm{g})$

$\mathrm{Na}(\mu \mathrm{g} / \mathrm{g})$

$\mathrm{Ni}(\mu \mathrm{g} / \mathrm{g})$

$\mathrm{S}(\mu \mathrm{g} / \mathrm{g})$

$\mathrm{P}(\mu \mathrm{g} / \mathrm{g})$

$\mathrm{Ti}(\mu \mathrm{g} / \mathrm{g})$
Undiluted Wash Solution

814

$-\dot{0}$

$-$

51,500

59,300

30,600

340

--

320

220

Not detected

1,760

Not detected

66,000

Not detected

Not detected

Not detected

Not detected
Wash Solution Diluted 1:1 with Demineralized Water and $\mathrm{NaOH}$ Addition 1,395

$<1,600$

$<3,200$

34,400

31,000

19,200

52

51

420

116

Not detected

807

Not detected

37,800

Not detected

Not detected

Not detected

Not detected

The capacity of the three media for Cs-137 was approximately the same, as evidenced by the similar amount of feed processed at $50 \%$ column breakthrough (see Figure 1). This was unexpected based on the $R_{d}$ values (Table 6). The $50 \%$ breakthrough and the $R_{d}$ values showed closer agreement in prior tests for IE-96 zeolite. The comparison of $R_{d}$ testing and column (DF) testing is as follows:

- Table 8 illustrates $R_{d}$ and column-testing DF data, as well as a comparison between the PNL-prepared TIE-96 zeolite and the UOP TIE-96 zeolite batches. For example, Cs-137 capacity for UOP 10004(b) was $81 \%$ of that for PNL's TIE-96 based on $R_{d}$ measurements, but $98 \%$ based on column tests.

- Even though the Cs-137 capacity appears to be essentially the same for UOP material when compared to PNL material, the initial DF was significantly lower (Figure 2). This initial DF was approximately 10,000 , while it was either 1,000 or 2,000 for UOP's material. The DFs are summarized in Table 9.

- The low Cs-137 removal performance can be attributed to test conditions in effect during this test. These included column temperatures that averaged 40 to $45^{\circ} \mathrm{C}$ and feed flow rates (Figure 3 ) to the columns that were maintained at 1.22 column volumes per hour (cv/hr). Actual STS experience has shown that high temperature and flow rate have a detrimental effect on Cs- 137 removal. 


\section{TRQ/TP-033 COLUMN TEST w/ TP-032 WASH 1 QUALIFICATION TESTING ON UOP 100 LB PILOT PLANT PRODUCTION OF TIE-96 ZEOLITE}

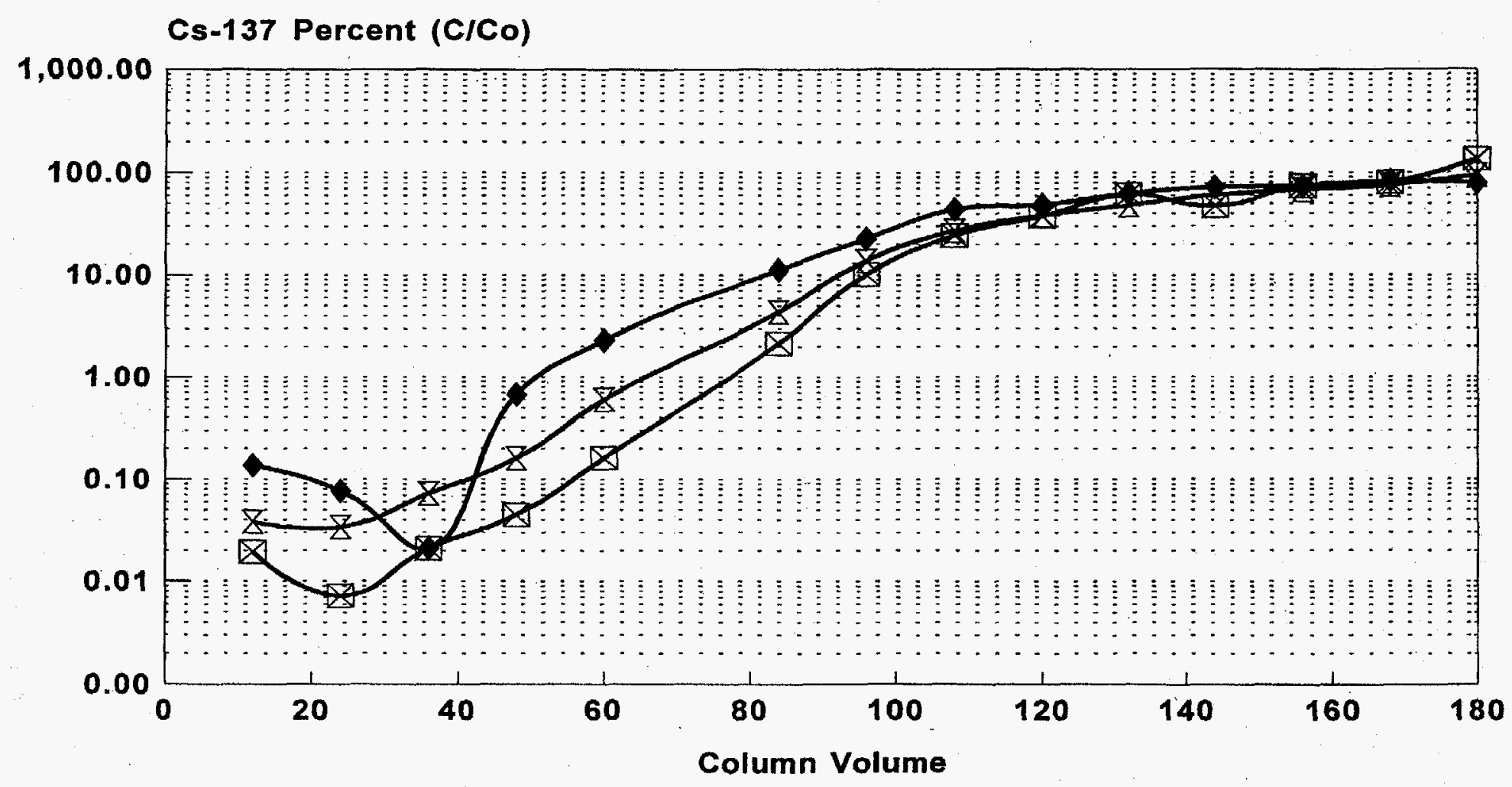

\&NL STD $\downarrow$ UOP(10004A) Z UOP(10004B)

CS-137, COLUMN TEMP. 40 DEGREE CELSIUS SINGLE-COLUMN, WVNS-TP-032 SLUDGE WASH 1 DILUTED 1:1 with DEMINERALIZED WATER

Figure 1. Cs-137 Single-column, WVNS-TP-032 (C/C $\mathrm{C}_{0}$ curve) 


\section{TRQ/TP-033 COLUMN TEST W/ TP-032 WASH 1 QUALIFICATION TESTING ON UOP 100 LB PILOT PLANT PRODUCTION OF TIE-96 ZEOLITE}

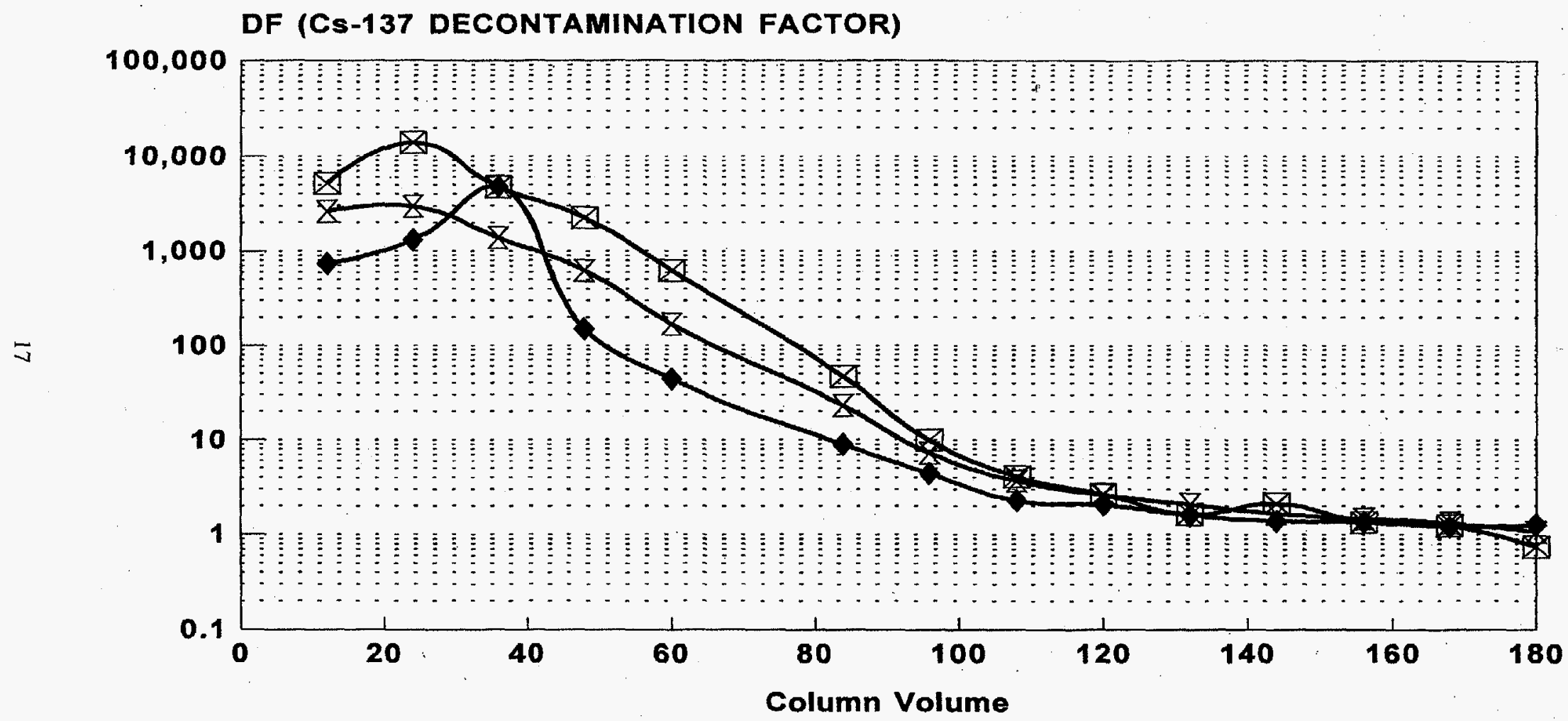

$\triangle$ PNL STD $\curvearrowleft$ UOP(10004A) Z UOP(10004B)

CS-137, COLUMN TEMP. 40 DEGREE CELSIUS SINGLE-COLUMN, WVNS-TP-032 SLUDGE WASH 1 DILUTED 1:1 with DEMINERALIZED WATER

Figure 2. CS-137 Single-column, WVNS-TP-032 (DF curve) 


\section{TRQ/TP-033 COLUMN TEST W/ TP-032 WASH 1 QUALIFICATION TESTING OF UOP 100 LB PILOT PLANT PRODUCTION OF TIE-96 ZEOLITE}

Flow Rate in Column Volume per Hour

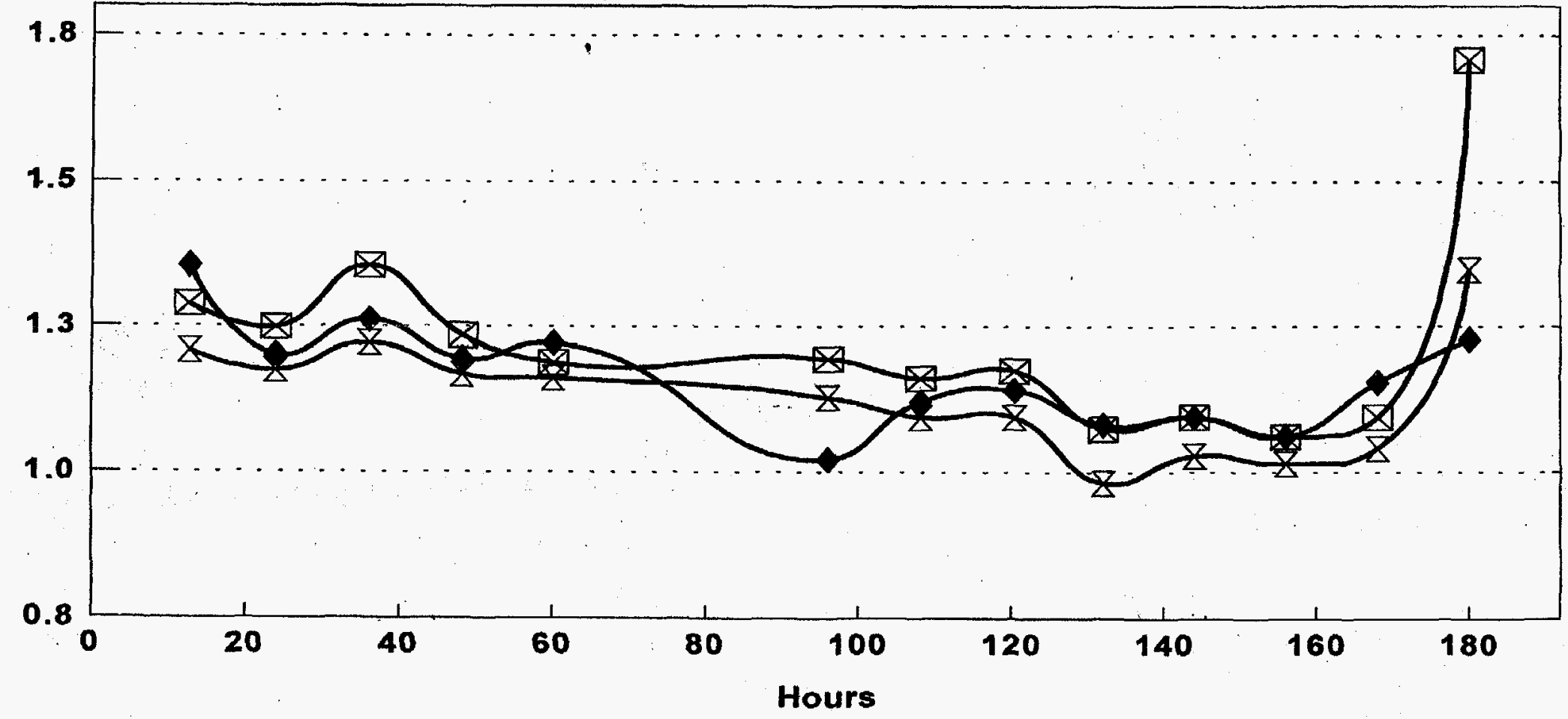

$\triangle$ PNL STD $\neg$ UOP(1.0004A) Z UOP(10004B)

COLUMN TEMP. 40 DEGREE CELSIUS

SINGLE-COLUMN, WVNS-TP-032 SLUDGE WASH 1

DILUTED 1:1 WITH DEMINERALIZED WATER

Figure 3. Single-column, WVNS-TP-032 (Flow Rates) 
Table 8. WVNS-TRQ/TP-033

Summary of the Cs-137 Capacity of Column-tested Zeolites

\begin{tabular}{|c|c|c|c|}
\hline & PNL TIE-96 & $\begin{array}{c}\text { UOP TIE-96 } \\
10004(\mathrm{a})\end{array}$ & $\begin{array}{l}\text { UOP TIE-96 } \\
\underline{10004(\mathrm{~b})}\end{array}$ \\
\hline $\mathbf{R}_{d}$ & 116 & 101 & 94 \\
\hline$R_{d} / 116$ & 1.00 & 0.87 & 0.81 \\
\hline Volume Processed at $50 \% \mathrm{BT},(\mathrm{CV})$ & 143.32 & 137.77 & 140.22 \\
\hline Volume Processed at $50 \%$ BT/143.32 & 1.00 & 0.96 & 0.98 \\
\hline \multicolumn{4}{|l|}{$\begin{array}{l}\text { BT - Breakthrough } \\
\text { CV - Column volume } \\
\text { (a) and (b) are from the same lot }\end{array}$} \\
\hline \multicolumn{4}{|c|}{$\begin{array}{l}\text { Breakthrough performance for all three columns was essentially the same with either Pu (Figure } 4 \text { ) or Sr-90 } \\
\text { (Figure 5). The Pu removal for UOP 10004(b) appears worse than for the other two, but a better interpretation } \\
\text { for the alpha-Pu decontamination factors illustrated in Figure } 6 \text { would be that PNL material performance was } \\
\text { bounded by the two UOP columns. This is because the range of Pu removal performance is estimated by the } \\
\text { replicate UOP columns. The reason for the difference in performance between sample (a) and sample (b) data } \\
\text { is attributed to non-uniform titanium-treatment of the pilot-scale batches. }\end{array}$} \\
\hline
\end{tabular}

\subsubsection{Leaching from Zeolite}

Induction Coupled Plasma (ICP) analyses on column effluent samples were used to determine the amount of leaching from the zeolite that may have occurred during the column test. Results have shown that there was apparently some amount of dissolution of the TIE-96 zeolites. To estimate the amount leached, the approach used was to subtract the average effluent concentration for a species from the feed concentration; multiply the difference by the total effluent mass; and compare the mass of that species to the zeolite analyses. Feed concentrations for iron, magnesium, and phosphorus were estimated using supernatant analysis and measured Cs- 137 analysis for the TP- 033 feed solution. This method was used because the values were reported below detection limits in the feed solution. No analyses were available for nickel or sulfur content in the feed solution. They were interpreted as total mass in the effluent.

The loss from the zeolite material is summarized in Table 10. Assuming that the values less than $10 \%$ (i.e., the reported accuracy of ICP) are negligible because they are based on a single-feed concentration value, aluminum and magnesium are the only two that were removed from the test columns. Chromium and sodium were not shown to be leached from the column. Aluminum, boron, calcium, and potassium appeared to be removed from the feed solution by TIE-96. Aluminum appeared to be leached from the zeolite media after breakthrough. 


\section{TRQ/TP-033 COLUMN TEST w/ TP-032 WASH 1 QUALIFICATION TESTING ON UOP 100 LB PILOT PLANT PRODUCTION OF TIE-96 ZEOLITE}

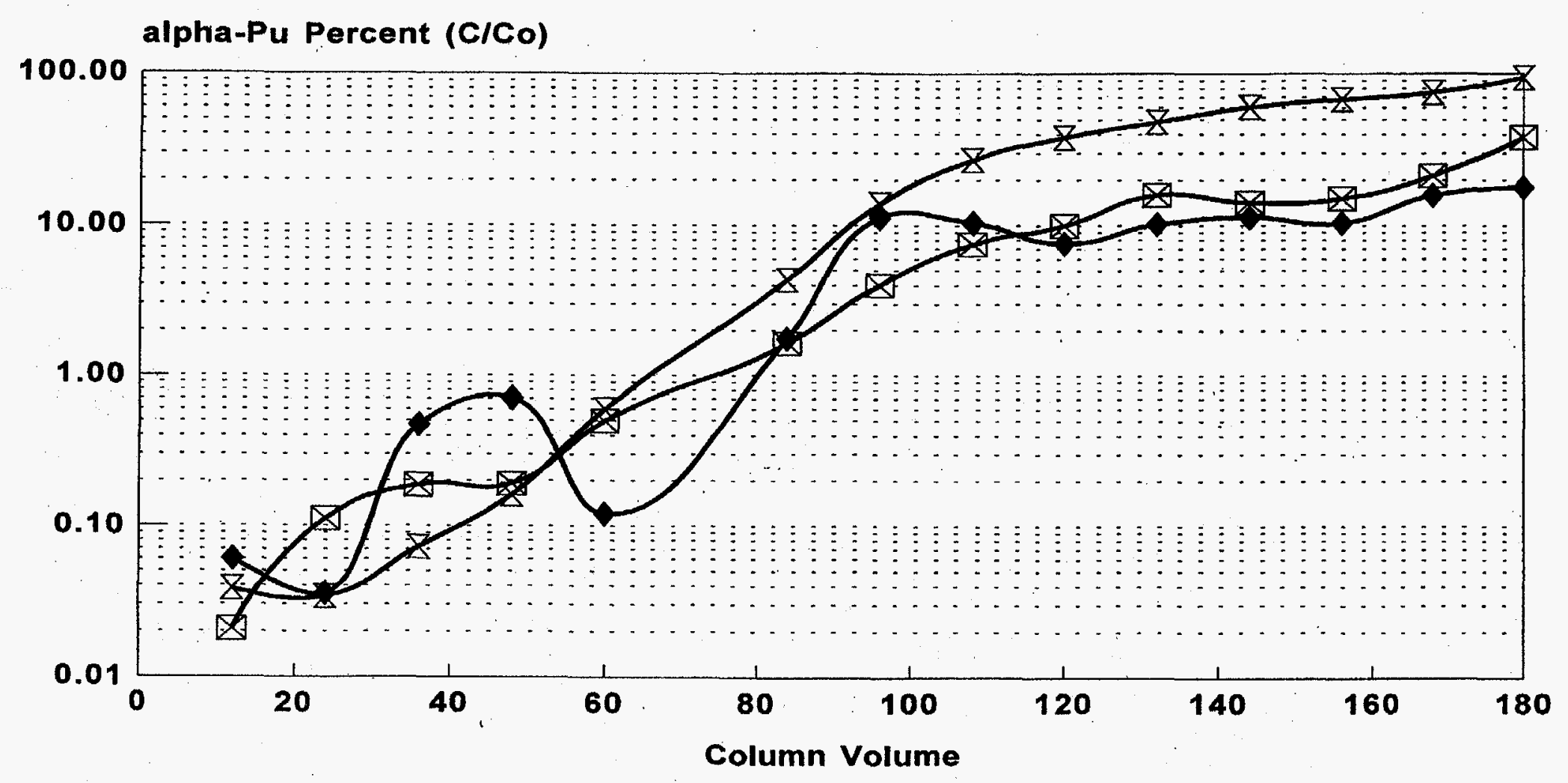

$\triangle$ PNL STD $\uparrow$ UOP(10004A) Z UOP(10004B) alpha-Pu, COLUMN TEMP. 40 DEGREE CELSIUS SINGLE-COLUMN, WVNS-TP-032 SLUDGE WASH 1 DILUTED 1:1 with DEMINERALIZED WATER

Figure 4. Alpha-Pu, Single-column, WVNS-TP-032 (C/C Curve) 


\section{TRQ/TP-033 COLUMN TEST w/ TP-032 WASH 1 QUALIFICATION TESTING OF UOP 100 LB PILOT PLANT PRODUCTION OF TIE-96 ZEOLITE}

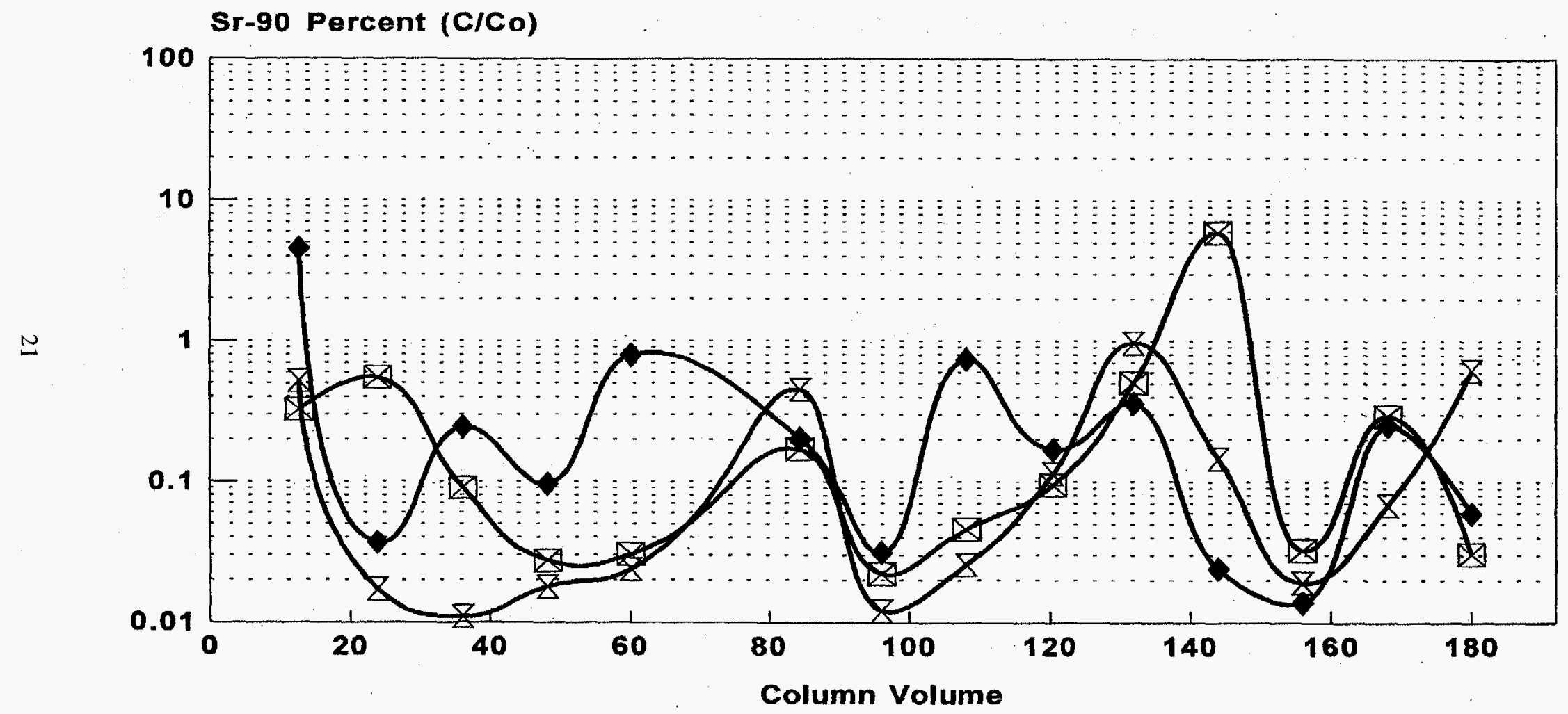

$\nexists$ PNL $(\mathrm{C} / \mathrm{CO}) \downarrow 10004 \mathrm{~A}(\mathrm{C} / \mathrm{CO}) \& 10004 \mathrm{~B}(\mathrm{C} / \mathrm{Co})$ Sr-90, COLUMN TEMP. 40 DEGREE CELSIUS SINGLE-COLUMN, WVNS-TP-032 SLUDGE WASH 1 DILUTED 1:1 with DEMINERALIZED WATER

Figure 5. Sr-90, Single-column, WVNS-TP-032 $\left(C / C_{0}\right.$ Curve $)$ 


\section{TRQ/TP-033 COLUMN TEST w/ TP-032 WASH 1 QUALIFICATION TESTING ON UOP 100 LB PILOT PLANT PRODUCTION OF TIE-96 ZEOLITE}

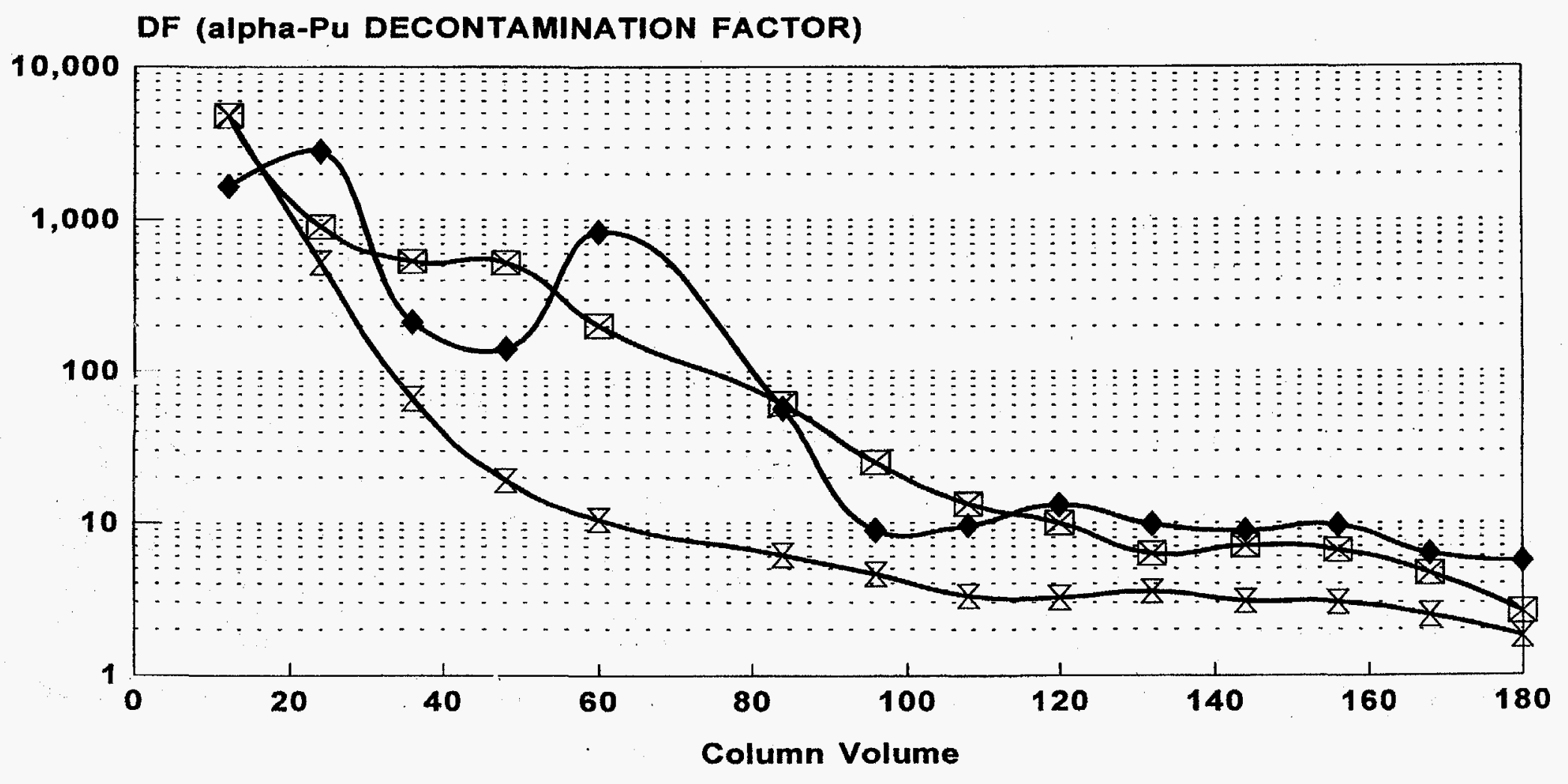

$\triangle$ PNL STD $\uparrow$ UOP(10004A) Z UOP(10004B)

alpha-Pu, COLUMN TEMP. 40 DEGREE CELSIUS

SINGLE-COLUMN, WVNS-TP-032 SLUDGE WASH 1

DILUTED 1:1 with DEMINERALIZED WATER

Figure 6. Alpha-Pu, Single-column, WVNS-TP-032 (DF Curve) 
Table 9. WVNS-TRQ/TP-033

Summary of the Results of Single-column Testing with WVNS-TP-032 Wash Cycle 1, Diluted 1:1, pH of 12:0:

alpha-Pu Decontamination Factor

$\underline{\text { Sample Resin }}$

PNL TIE-96

UOP TIE-96 10004(a)

UOP TIE-96 10004(b)

PNL TIE-96

UOP TIE-96 10004(a)

UOP TIE-96 10004(b) $\underline{40 \mathrm{cV}}$.

165

110

45

$\begin{array}{cc}\frac{80 \mathrm{cv}}{70} & \frac{180 \mathrm{cv}}{6} \\ 803 & 6 \\ 7 & 3\end{array}$

Cs-137 Decontamination Factor

$40 \mathrm{cv}$

4000

1400

1100
$180 \mathrm{cv}$

75

14

1

1

(a) and (b) are the same lot

Table 10. WVNS-TRQ/TP-033

Summary of Estimated Losses from the Titanium-treated Zeolite During Column Test

\begin{tabular}{lcccc}
\hline Species & $\mu \mathrm{g} / \mathrm{g}$ & $\begin{array}{c}\text { Feed Conc. } \\
\text { PNL TIE-96(\%) }\end{array}$ & $\begin{array}{c}\text { UOP TIE-96 } \\
10004(\mathrm{a})(\%)\end{array}$ & $\begin{array}{c}\text { UOP TIE-96 } \\
\mathrm{Al}\end{array}$ \\
52 & $45,(27)$ & $46,(36)$ & $42,(24)$ \\
$\mathrm{Fe}$ & 0.6 & 4 & $11,(4)$ & 3 \\
$\mathrm{Mg}$ & 0.022 & 56.6 & $62,(17)$ & $52,(13)$ \\
$\mathrm{Ni}$ & $\mathrm{n} / \mathrm{a}$ & 430 & 840 & 300 \\
$\mathrm{~S}$ & $\mathrm{n} / \mathrm{a}$ & 1.5 & 1.6 & 1.5 \\
$\mathrm{P}$ & $\mathrm{n} / \mathrm{a}$ & $210,(<0)$ & $190,(<0)$ & $300,(18)$ \\
\hline
\end{tabular}

( ) - repeat analyses

(a) and (b) are from the same lot 


\subsection{WVNS-TSR-037A "TIE-96 Zeolite Testing for Defining STS Operating Conditions"}

When TRQ-037 was initially issued, it identified a series of 12 laboratory column tests to evaluate the effects of solution temperature, $\mathrm{pH}$, and dilution on titanium-treated zeolite (TIE-96) efficiency for the removal of Cs137, Pu, and Sr-90 from Tank 8D-2 sludge wash solutions. ${ }^{8}$ It was intended that this parametric test matrix would identify operating parameters required for IRTS processing of sludge washes. The limited quantities of sludge wash cycle 1 solutions available and the schedule limitations demanded that TSR-042, a proof-of-the process test, be completed prior to completion of all tests identified in TRQ-037.

Preliminary results from qualification testing on the 100-1b pilot plant lots of TIE-96 prepared by UOP (TSR033) reported low Cs-137 removal at high temperatures (between 41 and $45^{\circ} \mathrm{C}$ ). This is why it was considered important to run the test at a low temperature. In addition, upgraded water chiller capacity for laboratory column-testing was made available to provide better lower temperature control. Only a single column of TIE-96 was evaluated in this test. ${ }^{9}$ It was tested at the following parameters: sludge wash cycle 1 diluted $1: 1$, temperature of $10^{\circ} \mathrm{C}$, and flow rate of 0.6 column volume per hour $(\mathrm{cv} / \mathrm{hr})$.

\subsubsection{Pre-column Test Analysis}

Measure the Anhydrous Weight of the TIE-96 used in Column:

When exposed to air, the zeolite molecular sieve material rapidly absorbs atmospheric moisture. Samples taken from the same source at different times can have the same apparent weight but different moisture levels. It is important to ensure that when comparing different column tests, the comparisons are done on an anhydrous weight basis of zeolite. The anhydrous weight percent of TIE-96 material charged to the ionexchange column was measured. The anhydrous weight product was performed in triplicate with an average of $82.39 \%$ of the "as-received" zeolite weight and a standard deviation of $0.074 \%$.

\subsubsection{Characterization of Column-test Feed Solution}

The column test solution used in this test was prepared as directed in WVNS-TP-036 from sludge core samples 1 and 2 collected from the M-4 riser of Tank 8D-2 during July 1991. This solution is designated as WVNSTP-036 wash cycle 1.9 The WVNS-TP-036 sludge wash cycle 1 solution was laboratory-filtered through a 0.45 -micron cellulose acetate membrane filter and diluted with demineralized water to a 1:1 ratio by weight. The undiluted and diluted sludge wash solutions were analyzed. The results are provided in Table 11.

\subsubsection{Test Results}

Ion-exchange Column Test - Column Temperature and Column Feed Solution Flow Rate:

The temperature for the TIE-96 column during this test was maintained at an average of $8.6 \pm 0.7^{\circ} \mathrm{C}$ during the test. The feed solution flow rate for the test was calculated to be $0.6 \mathrm{cv} / \mathrm{hr}$ and was consistent throughout the test. 


\subsubsection{Column Decontamination Factor (DF)}

The key parameter in this test of TIE-96 is the decontamination factor (DF) of the ion-exchange material at conditions anticipated for STS operations during sludge wash processing.

DFs for Cs- 137 were 10,000 at $50 \mathrm{cv}$ and 500 at $100 \mathrm{cv}$. DFs for alpha-Pu were approximately 1,000 at $50 \mathrm{cv}$ and 400 at $100 \mathrm{cv}$. The DF for Sr-90 was above 300 throughout the duration of the test. These results are shown in Figures 7 through 12. TIE-96 zeolite from UOP's pilot-plant production batch has demonstrated an acceptable capability for removal of $\mathrm{Cs}-137$ and alpha-Pu from sludge wash solution WVNS-TP-36 wash cycle 1, diluted 1:1 with demineralized water, $\mathrm{pH}$ 11.9. These results are acceptable and have shown that TIE96 at low-process temperatures and a $\mathrm{pH}$ of 11.9 can simultaneously remove $\mathrm{Cs}-137$, alpha-Pu, and $\mathrm{Sr}-90$ from diluted Tank 8D-2 sludge wash cycle 1 solutions. This is an advantageous result because the STS typically operates at low temperatures to maximize the Cs- 137 removal and minimize zeolite consumption.

Table 11. WVNS TRQ/TP-037A

Sludge Wash Analysis: WVNS TP-036 Sludge Wash 1

\begin{tabular}{|c|c|c|}
\hline Analysis & $\begin{array}{l}\text { Undiluted Sludge Wash } \\
\text { Cycle } 1 \text { Solution }\end{array}$ & $\begin{array}{l}\text { Sludge Wash Solution Diluted } \\
1: 1 \text { with Demineralized Water }\end{array}$ \\
\hline $\mathrm{pH}$ & 12.2 & 11.9 \\
\hline Total solids wt $\%$ (TS) & 20.8 & -- \\
\hline Density (gm/ml) & 1.162 & 1.076 \\
\hline Gross alpha $(\mu \mathrm{Ci} / \mathrm{g})$ & $<0.04$ & -- \\
\hline Gross beta $(\mu \mathrm{Ci} / \mathrm{g})$ & 801 & -- \\
\hline alpha-Pu $(\mu \mathrm{Ci} / \mathrm{g})$ & 0.0589 & 0.0224 \\
\hline $\mathrm{U}(\mu \mathrm{g} / \mathrm{g})$ & 14.7 & -- \\
\hline $\mathrm{Sr}-90(\mu \mathrm{Ci} / \mathrm{g})$ & 0.575 & 0.356 \\
\hline $\mathrm{Cs}-137(\mu \mathrm{Ci} / \mathrm{g})$ & 802 & 435 \\
\hline$F^{-}(\mu g / g)$ & $<120$ & -- \\
\hline $\mathrm{Cl}^{-}(\mu \mathrm{g} / \mathrm{g})$ & 420 & - \\
\hline $\mathrm{NO}_{2}^{-}(\mu \mathrm{g} / \mathrm{g})$ & 47,800 & -- \\
\hline $\mathrm{NO}_{3}^{-}(\mu \mathrm{g} / \mathrm{g})$ & 56,800 & -- \\
\hline $\mathrm{SO}_{4}^{-}(\mu \mathrm{g} / \mathrm{g})$ & 21,800 & -- \\
\hline $\mathrm{Al}(\mu \mathrm{g} / \mathrm{g})$ & 1,080 & - \\
\hline B $(\mu g / g)$ & 337 & - \\
\hline $\mathrm{Ca}(\mu \mathrm{g} / \mathrm{g})$ & 410 & 105 \\
\hline $\mathrm{Cr}(\mu \mathrm{g} / \mathrm{g})$ & 222 & 110 \\
\hline $\mathrm{Fe}(\mu \mathrm{g} / \mathrm{g})$ & 110 & - \\
\hline $\mathrm{K}(\mu \mathrm{g} / \mathrm{g})$ & 2,570 & - \\
\hline
\end{tabular}


Table 11. WVNS TRQ/TP-037A (continued)

Sludge Wash Analysis: WVNS TP-036 Sludge Wash 1

\begin{tabular}{lcc}
\hline$\underline{\text { Analysis }}$ & $\begin{array}{c}\text { Undiluted Sludge Wash } \\
\text { Cycle 1 Solution }\end{array}$ & $\begin{array}{c}\text { Sludge Wash Solution Diluted } \\
1: 1 \text { with Demineralized Water }\end{array}$ \\
$\mathrm{Na}(\mu \mathrm{g} / \mathrm{g})$ & 64,700 & 31,000 \\
$\mathrm{~S}(\mu \mathrm{g} / \mathrm{g})$ & 7,080 & -- \\
$\mathrm{P}(\mu \mathrm{g} / \mathrm{g})$ & 322 & 85.7 \\
$\mathrm{Ti}(\mu \mathrm{g} / \mathrm{g})$ & $<66$ & - \\
\hline
\end{tabular}



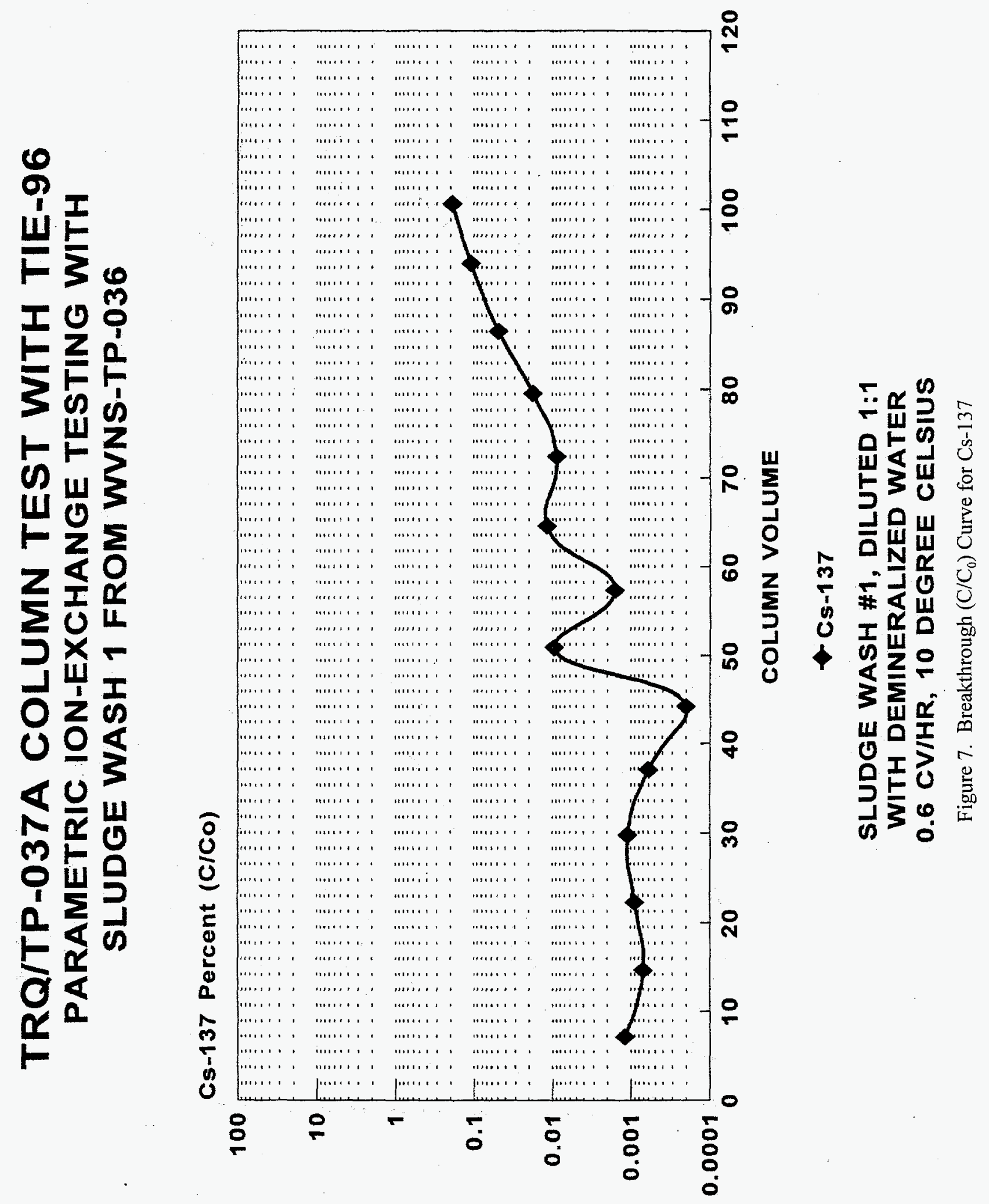


\section{TRQ/TP-037A COLUMN TEST WITH TIE-96 \\ PARAMETRIC ION-EXCHANGE TESTING WITH \\ SLUDGE WASH 1 FROM WVNS-TP-036}

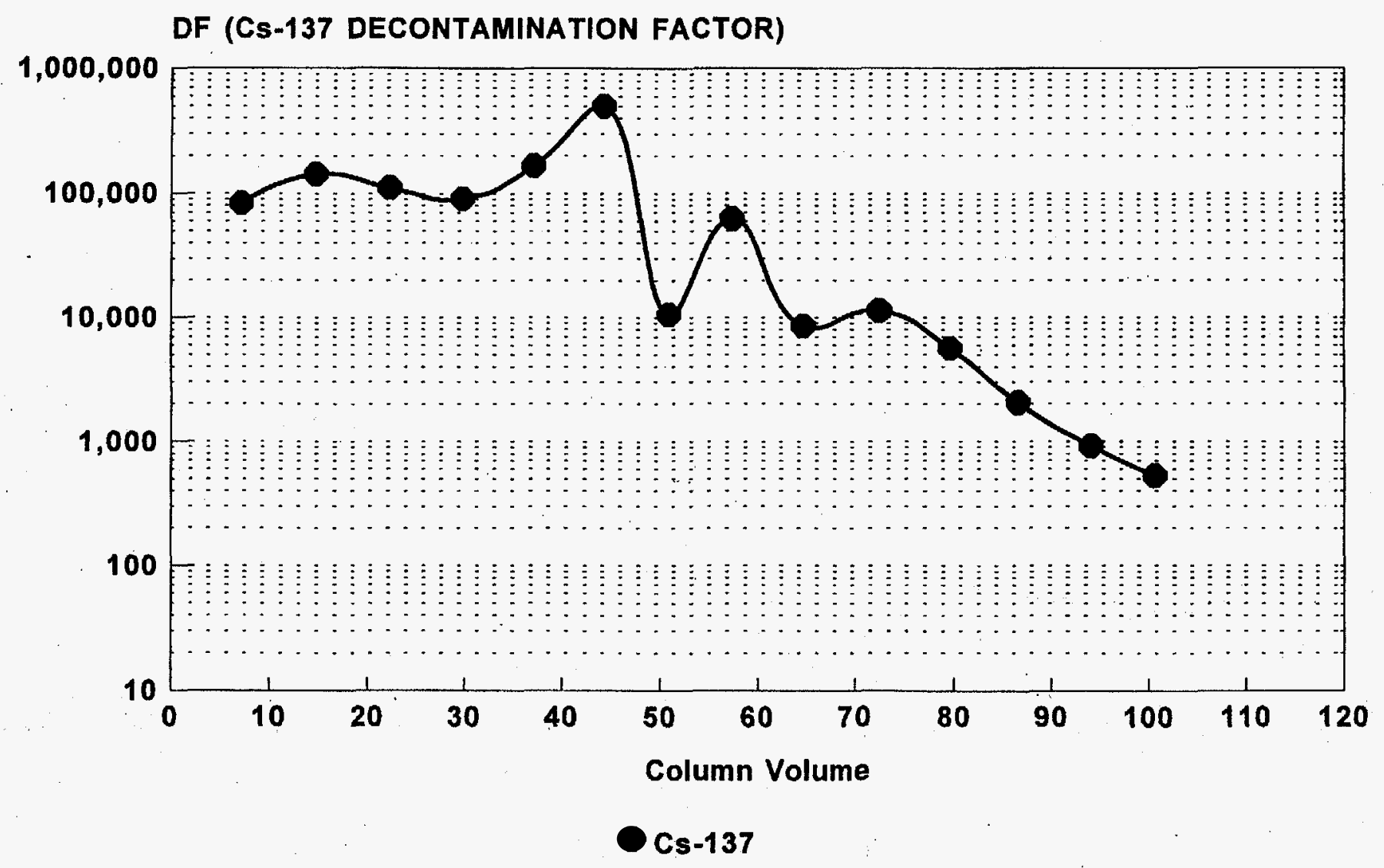

SLUDGE WASH \#1, DILUTED 1:1

WITH DEMINERALIZED WATER

0.6 CVIHR, 10 DEGREE CELSIUS

Figure 8. Decontamination Factor (DF) Curve for Cs-137 


\section{TRQ/TP-037A COLUMN TEST WITH TIE-96 \\ PARAMETRIC ION-EXCHANGE TESTING WITH \\ SLUDGE WASH 1 FROM WVNS-TP-036}

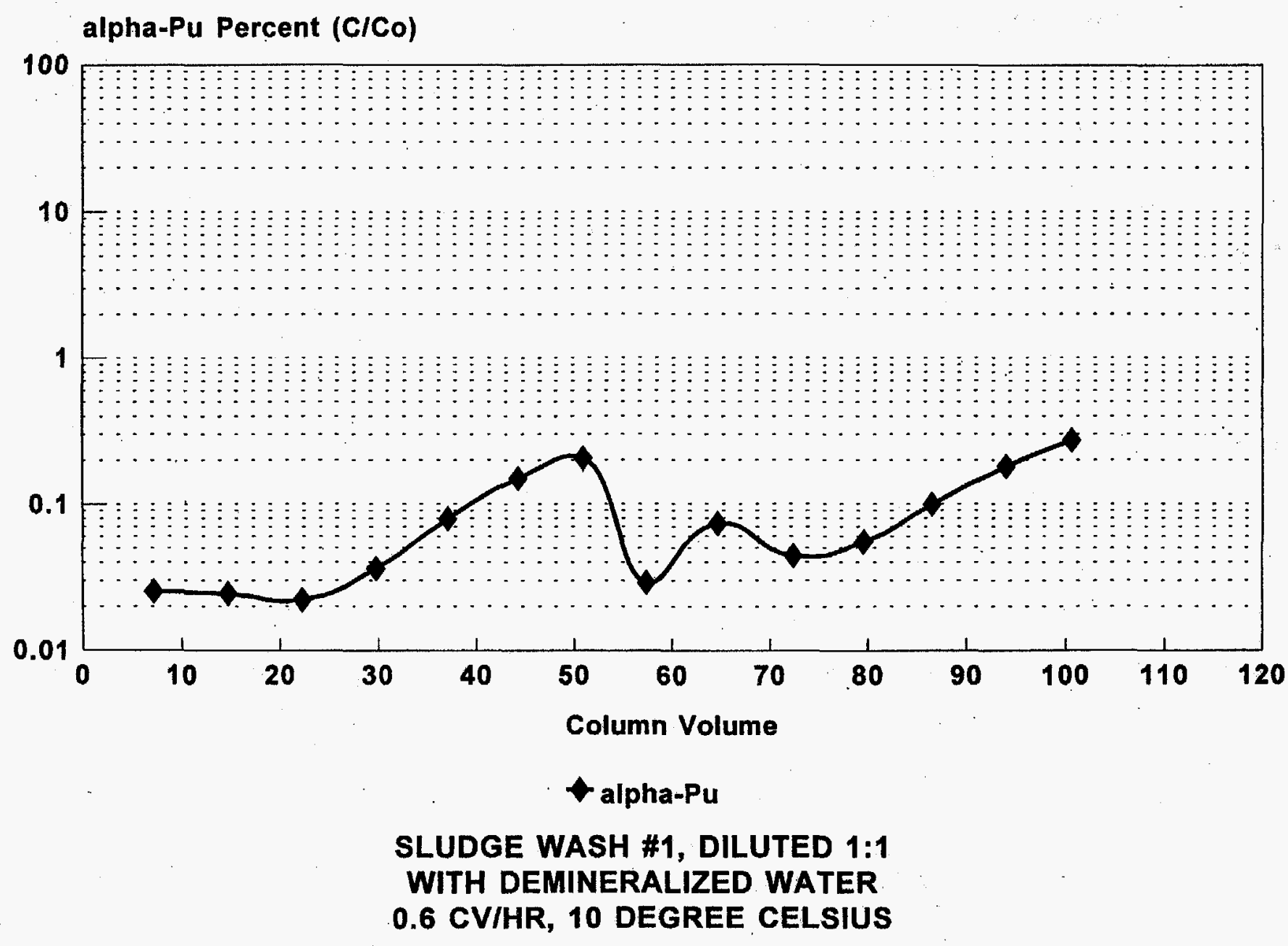

Figure 9. Breakthrough $\left(\mathrm{C} / \mathrm{C}_{0}\right)$ Curve for alpha-Pu 


\section{TRQ/TP-037A COLUMN TEST WITH TIE-96 \\ PARAMETRIC ION-EXCHANGE TESTING WITH \\ SLUDGE WASH 1 FROM WVNS-TP-036}

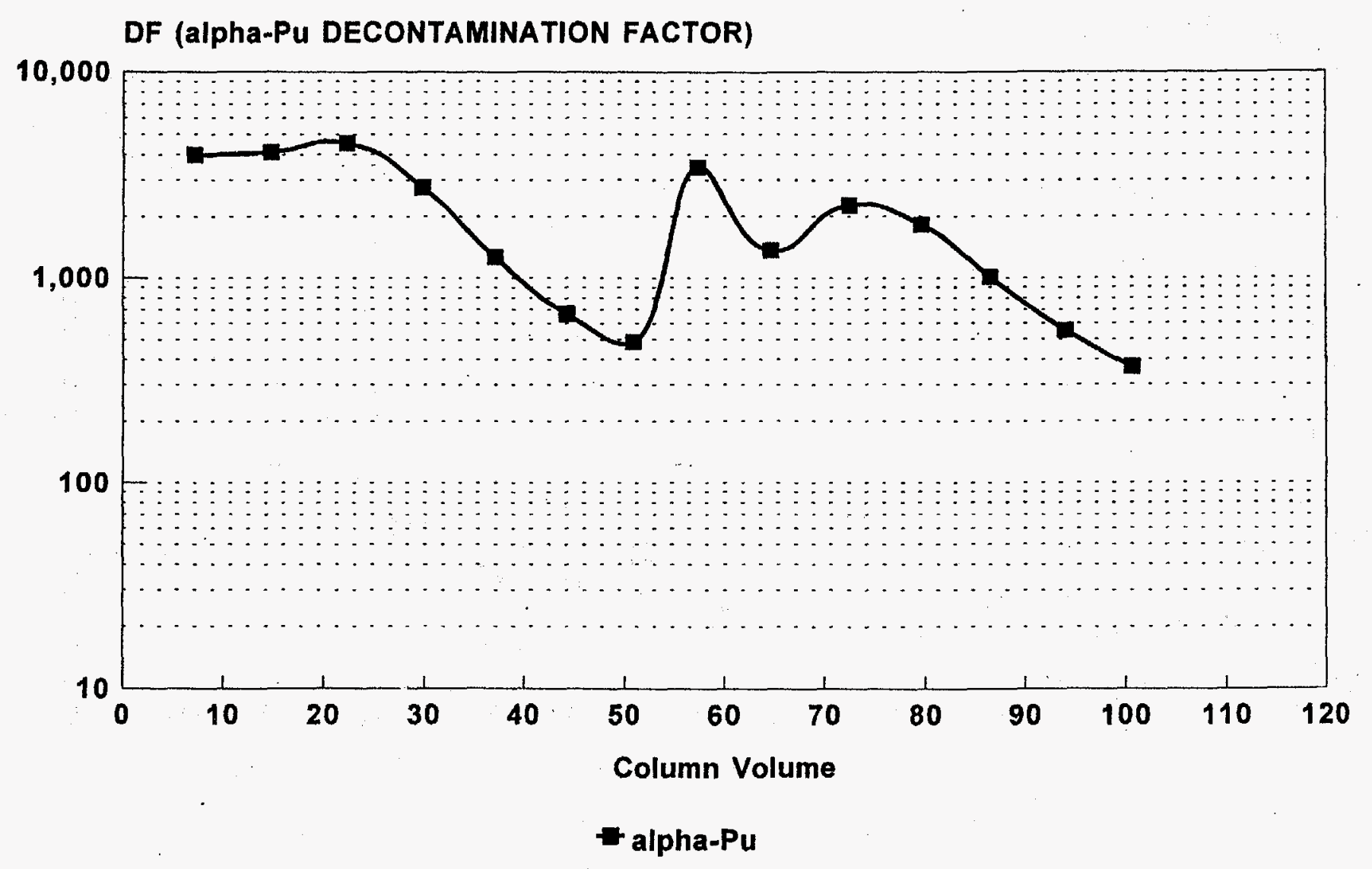

SLUDGE WASH \#1, DILUTED 1:1 WITH DEMINERALIZED WATER 0.6 CVIHR, 10 DEGREE CELSIUS

Figure 10. Decontamination Factor (DF) Curve for alpha-Pu 


\section{TRQ/TP-037A COLUMN TEST WITH TIE-96 \\ PARAMETRIC ION-EXCHANGE TESTING WITH SLUDGE WASH 1 FROM WVNS-TP-036}

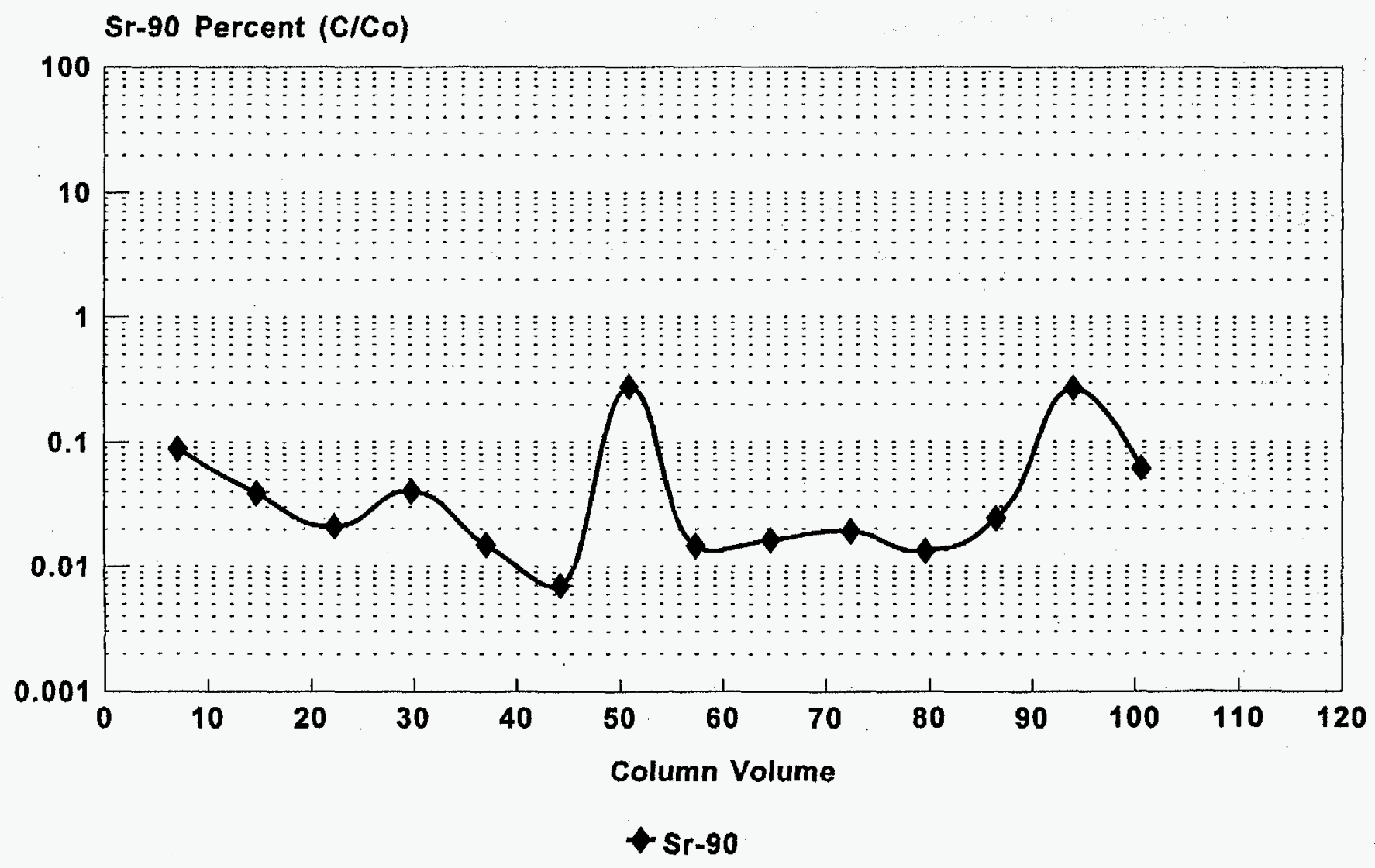

SLUDGE WASH \#1, DILUTED 1:1 WITH DEMINERALIZED WATER $0.6 \mathrm{CV} / \mathrm{HR}, 10$ DEGREE CELSIUS

Figure 11. Breakthrough $\left(\mathrm{C} / \mathrm{C}_{0}\right)$ Curve for $\mathrm{Sr}-90$ 


\section{TRQ/TP-037A COLUMN TEST WITH TIE-96 \\ PARAMETRIC ION-EXCHANGE TESTING WITH SLUDGE WASH 1 FROM WVNS-TP-036}

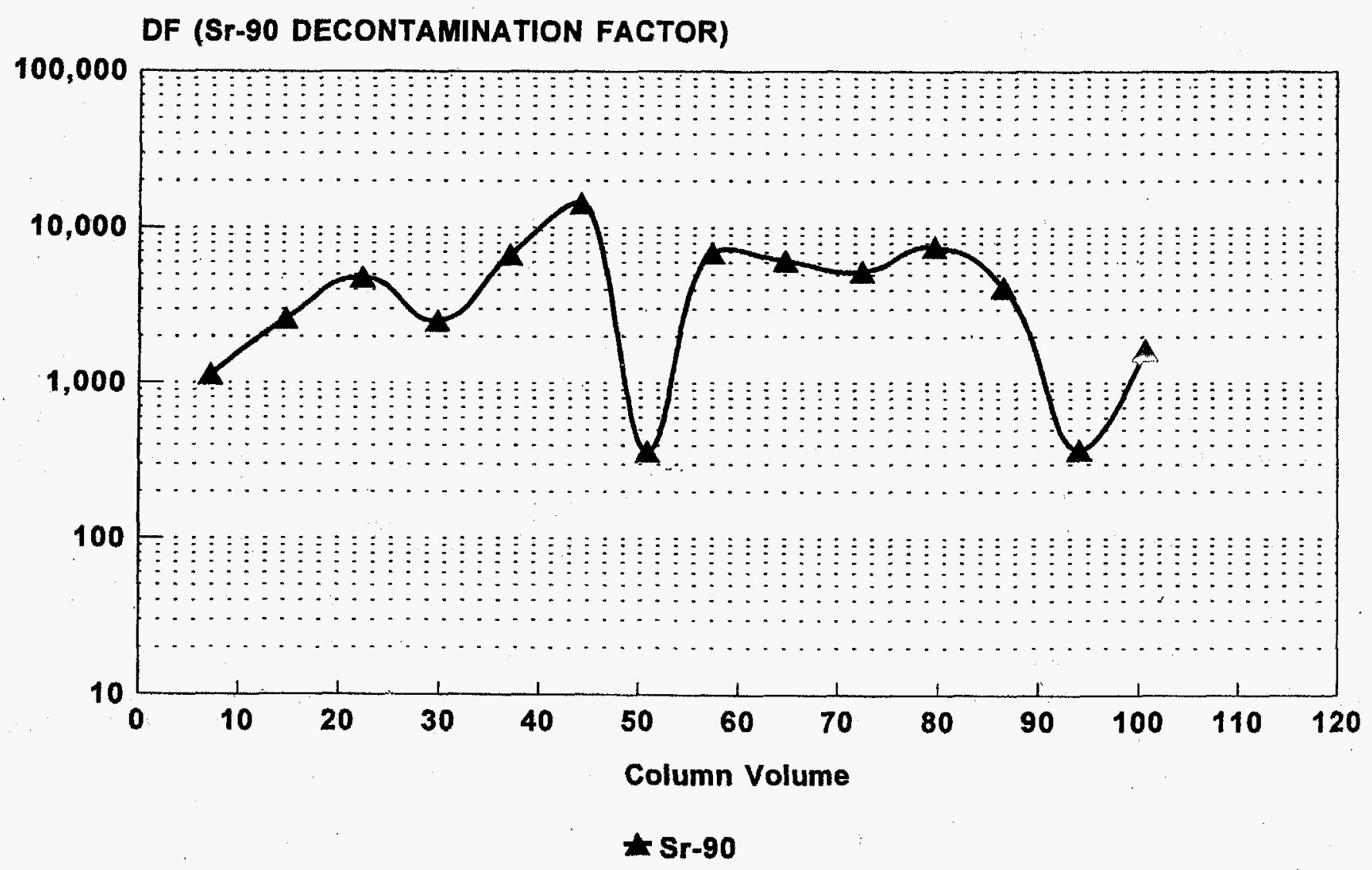

SLUDGE WASH \#1, DILUTED 1:1 WITH DEMINERALIZED WATER 0.6 CV/HR, 10 DEGREE CELSIUS

Figure 12. Decontamination Factor (DF) Curve for Sr-90 


\subsection{WVNS-TSR-037B "TIE-96 Zeolite Testing for Defining STS Operating Conditions"}

This test was a continuation of the parametric test matrix test identified for TIE-96. ${ }^{10}$ This test matrix identified a series of laboratory column tests to evaluate the effects of solution temperature, dilution, and $\mathrm{pH}$ on the TIE-96 efficiency for the removal of Cs-137, Pu, and Sr-90 from Tank 8D-2 sludge wash solutions. (At the completion of WVNS-TRQ/TP-042, a proof-of-the process test ${ }^{11}$ discussed later in section 4.5 , it was decided that additional processing information should be obtained.) Tests were identified that would provide pertinent information to support IRTS processing of sludge wash solutions. Part 1 of this test evaluated the effect of solution $\mathrm{pH}$ on TIE-96 efficiency for the removal of Cs-137, alpha-Pu, and Sr-90 from Tank 8D-2 sludge wash solution prepared in the A\&PC Laboratory under WVNS-TP-039A. Single columns of TIE-96 were tested at $10^{\circ} \mathrm{C}$ with solutions at $\mathrm{pH} 11.6$ and 12.0 . Part 2 of the revised test called for the evaluation of temperature on TIE-96 efficiency for the removal of Cs-137, alpha-Pu, and Sr-90 from actual Tank 8D-2 sludge wash solution diluted to a Cs-137 concentration of $435 \mu \mathrm{Ci} / \mathrm{g}$. This part of the test evaluated zeolite performance utilizing two sets of laboratory-scale columns, each consisting of a IE-96 zeolite (IE-96) column followed in series by a TIE-96 column. This testing was carried out at both $10^{\circ} \mathrm{C}$ and laboratory cell temperatures, typically $26^{\circ} \mathrm{C}$.

\subsubsection{Zeolite Material}

The TIE-96 zeolite used in this test was prepared in UOP's Mobile, Alabama manufacturing facility, in production-scale process equipment and identified as grand lot sample 9757-91-990001. The IE-96 zeolite used in this test was previously prepared in UOP's Mobile, Alabama manufacturing facility, as grand lot 93960990001 , drum 17.

\subsubsection{Physical Characterization and Weights of the Zeolites Used -- Anhydrous Weight Percent}

The zeolite molecular sieve material absorbs atmospheric moisture rapidly when exposed to air. Samples taken from the same source at different times can have the same apparent weight but are at different moisture levels. It is important to ensure that different column tests are done on an anhydrous weight basis of zeolite. The anhydrous weight percent of the zeolites charged to the ion-exchange columns were measured. The results are as follows:

TIE-96: $81.7 \% \quad$ IE-96: $79.3 \%$

\subsubsection{Density}

The tap density (the weight of a measured volume of zeolite as measured in a graduated cylinder) of zeolites used to charge the columns was measured and the average densities are as follows:

TIE-96: $0.925 \mathrm{~g} / \mathrm{ml} \quad$ IE-96: $0.920 \mathrm{~g} / \mathrm{ml}$ 


\subsubsection{Zeolite "As-received" Weight Charged to the Columns}

\begin{tabular}{|c|c|c|}
\hline TSR-037B Part 1 & $\begin{array}{l}\text { Column test: } \\
\text { Zeolite column(1): } \\
\text { Target (grams): } \\
\text { Actual (grams): }\end{array}$ & $\begin{array}{l}10^{\circ} \mathrm{C}, \mathrm{pH} 12.0, \\
\mathrm{TIE}-96 \\
1.480 \\
1.484\end{array}$ \\
\hline $\begin{array}{l}\text { TSR-037B Part } 1 \\
\text { (continued) }\end{array}$ & $\begin{array}{l}\text { Column test : } \\
\text { Zeolite column(1): } \\
\text { Target (grams): } \\
\text { Actual (grams): }\end{array}$ & $\begin{array}{l}10^{\circ} \mathrm{C}, \mathrm{pH} 11.6 \\
\mathrm{TIE}-96 \\
1.480 \\
1.486\end{array}$ \\
\hline TSR-037B Part 2 & $\begin{array}{l}\text { Column test: } \\
\text { Zeolite column(1): } \\
\text { Target (grams): } \\
\text { Actual (grams): } \\
\text { Zeolite column(2): } \\
\text { Target (grams) : } \\
\text { Actual (grams) : } \\
\text { Column test: } \\
\text { Zeolite column(1): } \\
\text { Target (grams) : } \\
\text { Actual (grams) : } \\
\text { Zeolite Column(2): } \\
\text { Target (grams): } \\
\text { Actual (grams): }\end{array}$ & $\begin{array}{l}10^{\circ} \mathrm{C} \text {, Actual Tank } 8 \mathrm{D}-2 \text { wash \#1 } \\
\mathrm{IE}-96 \\
1.472 \\
1.472 \\
\text { TIE-96 } \\
1.480 \\
1.485 \\
26^{\circ} \mathrm{C} \text {, Actual Tank } 8 \mathrm{D}-2 \text { wash \#1 } \\
\mathrm{IE}-96 \\
1.472 \\
1.472 \\
\text { TIE-96 } \\
1.480 \\
1.484\end{array}$ \\
\hline
\end{tabular}

\subsubsection{Characterization of Column-test Feed Solutions}

\subsubsection{TRQ/TP-337B Part 1 -- Laboratory Sludge Wash Solutions}

The column test solution used in this part of the test was prepared as directed in test procedure WVNS-TP-039 from sludge core sample 3 collected from the M-4 riser of Tank 8D-2 during July 1991. This solution is designated as WVNS-TP-039 wash cycle $1 .^{12}$ The WVNS-TP-039 sludge wash cycle 1 solution was laboratory-filtered through a 0.45 -micron cellulose acetate membrane filter and the filtered solution was diluted with demineralized water to a $1: 1$ ratio by weight. The diluted sludge wash solution was analyzed and the results are provided in Table 12 as the $\mathrm{pH} 12.0$ test. One hundred ninety-four and six tenths grams of the previously diluted 1:1 sludge wash cycle 1 solution prepared in test procedure WVNS-TP-039A were $\mathrm{pH}$ adjusted with sodium carbonate $\left(\mathrm{NaHCO}_{3}\right)$ from an initial $\mathrm{pH}$ of 12.0 to a final $\mathrm{pH}$ of 11.6. The analyses on this adjusted solution are also provided in Table 12 as the $\mathrm{pH} 11.6$ test. 


\subsubsection{TRQ/TP-037B Part 2 -- Tank 8D-2 Sludge Wash Solution}

The Tank 8D-2 sludge wash 1 solution was collected by STS Operations on December 19, 1991. The samples of the solutions were composited and laboratory-filtered through a 0.45 micron membrane filter. The filtered solution was diluted to a Cs-137 concentration of $435 \mu \mathrm{Ci} / \mathrm{g}$ with demineralized water to simulate the dilution of the actual Tank 8D-2 sludge wash solution that was anticipated for feed to STS processing. The analyses are provide in Table 13 for both the undiluted and diluted Tank 8D-2 sludge wash.

Table 12. WVNS TP-037B

Part 1 Column-test Feed Solutions WVNS TP-039 Sludge Wash Cycle 1, Diluted 1:1 with Demineralized Water

\begin{tabular}{lll}
\hline Analysis & pH 12.0 Test & pH 11.6 Test \\
pH & 12.0 & 11.6 \\
Total Solids wt\% (TS) & 13.0 & 13.2 \\
Density $(\mathrm{gm} / \mathrm{ml})$ & 1.100 & 1.102 \\
Total Inorganic Carbon(TIC) $(\mu \mathrm{g} / \mathrm{g})$ & 2,200 & 2,640 \\
alpha-Pu $(\mu \mathrm{Ci} / \mathrm{g})$ & 0.0959 & 0.0962 \\
$\mathrm{Sr}-90(\mu \mathrm{Ci} / \mathrm{g})$ & 0.1020 & 0.1010 \\
$\mathrm{Cs}-137(\mu \mathrm{Ci} / \mathrm{g})$ & 433 & 435 \\
$\mathrm{~F}^{-}(\mu \mathrm{g} / \mathrm{g})$ & 120 & 120 \\
$\mathrm{Cl}(\mu \mathrm{g} / \mathrm{g})$ & 315 & 281 \\
$\mathrm{NO} 2^{-}(\mu \mathrm{g} / \mathrm{g})$ & 30,500 & 30,500 \\
$\mathrm{NO} 3^{-}(\mu \mathrm{g} / \mathrm{g})$ & 32,500 & 32,300 \\
$\mathrm{SO} 4(\mu \mathrm{g} / \mathrm{g})$ & 16,400 & 16,600 \\
$\mathrm{Ca}(\mu \mathrm{g} / \mathrm{g})$ & 75 & 96 \\
$\mathrm{Cr}(\mu \mathrm{g} / \mathrm{g})$ & 108 & 109 \\
$\mathrm{Fe}(\mu \mathrm{g} / \mathrm{g})$ & $<$ det. limit & 2 \\
$\mathrm{~K}(\mu \mathrm{g} / \mathrm{g})$ & 920 & 918 \\
$\mathrm{Na}(\mu \mathrm{g} / \mathrm{g})$ & 32,700 & 36,700 \\
$\mathrm{Ti}(\mu \mathrm{g} / \mathrm{g})$ & $<$ det. limit & $<$ det. limit \\
\hline$<\mathrm{det} / \mathrm{mit}-\mathrm{bew}$ & &
\end{tabular}

$<$ det. limit - below instrument detection limit or no detection

\subsubsection{Ion-exchange Column Tests}

\subsubsection{TRQ-037B Part 1}




\subsection{Column Temperature and Column Feed Solution Flow Rate}

The actual temperature of both TIE- 96 columns was sustained at an average of $10.6 \pm 0.7^{\circ} \mathrm{C}$ during the test. The actual flow rate was calculated to be at an average of $0.55 \mathrm{cv} / \mathrm{hr}$ for the $\mathrm{pH} 12 \mathrm{column}$ and $0.57 \mathrm{cv} / \mathrm{hr}$ for the $\mathrm{pH} 11.6$ column.

Table 13. WVNS TRQ/TP-037B

Tank 8D-2 Sludge Wash 1 Analyses

\section{Analysis}

$\mathrm{pH}$

Total solids wt $\%$ (TS)

Density (gm/ml)

Total Organic Carbon TOC $(\mu \mathrm{g} / \mathrm{g})$

Total Inorganic Carbon TIC $(\mu \mathrm{g} / \mathrm{g})$

Gross alpha $(\mu \mathrm{Ci} / \mathrm{g})$

Gross beta $(\mu \mathrm{Ci} / \mathrm{g})$

alpha-Pu $(\mu \mathrm{Ci} / \mathrm{g})$

$\mathrm{U}(\mu \mathrm{g} / \mathrm{g})$

$\mathrm{Sr}-90(\mu \mathrm{Ci} / \mathrm{g})$

$\mathrm{Cs}-137(\mu \mathrm{Ci} / \mathrm{g})$

$\mathrm{F}^{-}(\mu \mathrm{g} / \mathrm{g})$

$\mathrm{Cl}^{-}(\mu \mathrm{g} / \mathrm{g})$

$\mathrm{NO}^{-}(\mu \mathrm{g} / \mathrm{g})$

NO3 $^{-}(\mu \mathrm{g} / \mathrm{g})$

$\mathrm{SO}^{-}(\mu \mathrm{g} / \mathrm{g})$

Al $(\mu \mathrm{g} / \mathrm{g})$

B $(\mu \mathrm{g} / \mathrm{g})$

$\mathrm{Ca}(\mu \mathrm{g} / \mathrm{g})$

$\mathrm{Cr}(\mu \mathrm{g} / \mathrm{g})$

$\mathrm{Fe}(\mu \mathrm{g} / \mathrm{g})$

$\mathrm{K}(\mu \mathrm{g} / \mathrm{g})$

$\mathrm{Na}(\mu \mathrm{g} / \mathrm{g})$

$\mathrm{S}(\mu \mathrm{g} / \mathrm{g})$

$\mathrm{P}(\mu \mathrm{g} / \mathrm{g})$

$\mathrm{Ti}(\mu \mathrm{g} / \mathrm{g})$

\section{Undiluted Sludge}

Wash Solution

12.6

21.1

1.161

not done

$--$

$<0.04$

801

0.0260

8

0.253

797

$<120$

554

52,900

55,700

19,700

311

22

177

199

$<$ det. limit

2,310

87,000

7,620

165
Sludge Wash Solution Diluted

with Demineralized Water

12.3

11.9

1.085

$\sim 300$

1,400

--

$-$

0.0145

0.148

442

$\sim 73$

210

27,900

30,500

10,600

157

11

2

127

2

887

34,700

2,640

85

$<$ det. limit

$<$ det. limit

$<$ det. limit - below instrument detection limit or no detection 


\subsection{Column Decontamination Factor (DF)}

Each TIE-96 column effluent was collected at 24-hour intervals and analyzed for Cs-137, alpha-Pu, and Sr-90. Breakthrough $\left(\mathrm{C} / \mathrm{C}_{0}\right)$ curves are provided for $\mathrm{Cs}-137$, alpha-Pu, and Sr-90 in Figures 13, 14, and 15, respectively. Decontamination factors from this test are summarized in Table 14.

\section{$\mathrm{pH} 12.0$ Test}

The DF for Cs- 137 was greater than 1 million at $50 \mathrm{cv}$; greater than 20,000 at $100 \mathrm{cv}$; and 2,000 at $120 \mathrm{cv}$. DF for alpha-Pu was approximately 3,000 at $50 \mathrm{cv}$; approximately 56 at $100 \mathrm{cv}$; and 22 at $120 \mathrm{cv}$. DF for Sr-90 was greater than 1,000 for the duration of test.

\section{$\mathrm{pH} 11.6$ Test}

The DF for Cs- 137 was greater than 1 million at $50 \mathrm{cv} ; 10,000$ at $100 \mathrm{cv}$; and 1,600 at $120 \mathrm{cv}$. DF for alpha$\mathrm{Pu}$ was approximately 25 at $50 \mathrm{cv}$; approximately 3 at $100 \mathrm{cv}$; and 1.5 at $120 \mathrm{cv}$. DF for $\mathrm{Sr}-90$ was greater than 1,000 for the duration of test.

Table 14. Summary of Decontamination Factors for TSR-037B Part 1 Single TIE-96 Zeolite Columns Tests Laboratory-prepared Tank 8D-2 Sludge Wash Cycle 1, Diluted 1:1

\begin{tabular}{|c|c|c|c|c|c|}
\hline \multirow[b]{2}{*}{$\underline{\text { Column Test }}$} & \multicolumn{5}{|c|}{ Cs-137 Decontamination Factor } \\
\hline & $\underline{\mathrm{pH}}$ & Feed & $\underline{50 \mathrm{cv}}$ & $100 \mathrm{cv}$ & $120 \mathrm{cv}$ \\
\hline TP-037A & 11.9 & ТP-036 & 10,000 & 500 & * \\
\hline TP-037B1 & 11.6 & TP-039A & $>1 \times 10^{6}$ & $>10,000$ & 1,600 \\
\hline \multirow[t]{2}{*}{ TP-037B 1} & 12.0 & TP-039A & $>12 \times 10^{6}$ & $>20,000$ & 2,000 \\
\hline & \multicolumn{5}{|c|}{ alpha-Pu Decontamination Factor } \\
\hline Column Test & $\mathrm{pH}$ & Feed & $\underline{50 \mathrm{cv}}$ & $\underline{100 \mathrm{cv}}$ & $\underline{120 \mathrm{cv}}$ \\
\hline TP-037A & 11.9 & TP-036 & 50,000 & 40,000 & * \\
\hline TP-037B1 & 11.6 & TP-039A & 25 & 3 & 1.5 \\
\hline \multirow[t]{2}{*}{ TP-037B1 } & 12.0 & TP-039A & 3,000 & 56 & 22 \\
\hline & \multicolumn{5}{|c|}{$\underline{\text { Sr-90 Decontamination Factor }}$} \\
\hline Column Test & $\mathrm{pH}$ & Feed & $\underline{50 \mathrm{cV}}$ & $\underline{100 \mathrm{cV}}$ & $120 \mathrm{cv}$ \\
\hline TP-037A & 11.9 & TP-036 & $>300,000$ & $>300,000$ & * \\
\hline TP-037B1 & 11.6 & TP-039A & $>2,500$ & $>2,500$ & $>2,500$ \\
\hline TP-037B1 & 12.0 & TP-039A & $>6,000$ & $>6,000$ & $>6,000$ \\
\hline
\end{tabular}

* TP-037A processed only $100 \mathrm{cv}$ of solution

B1 - Part 1 Column Test 


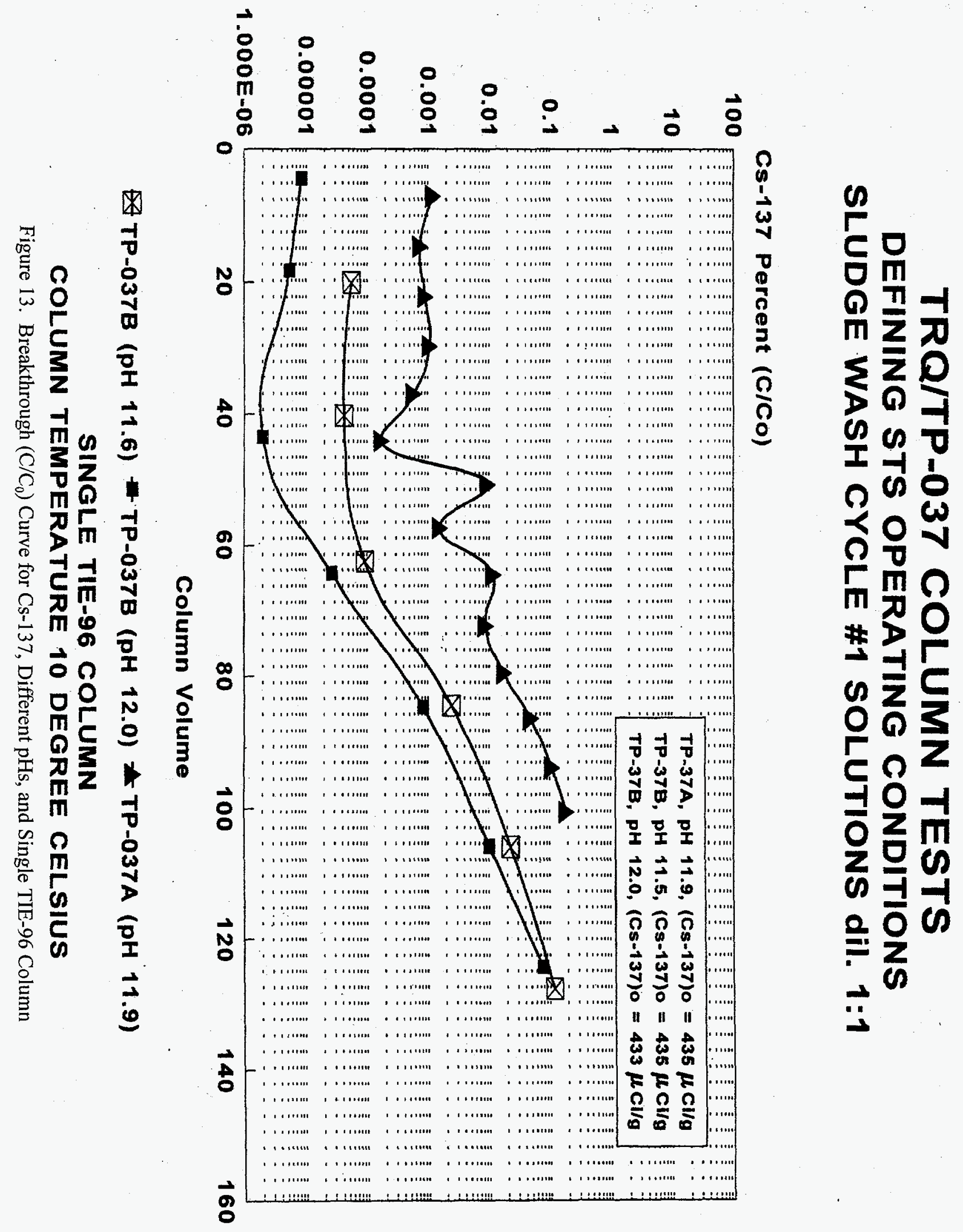




\section{TRQ/TP-037 LABORATORY COLUMN TESTS DEFINING STS OPERATING CONDITIONS SLUDGE WASH CYCLE \#1 SOLUTIONS diI. 1:1}

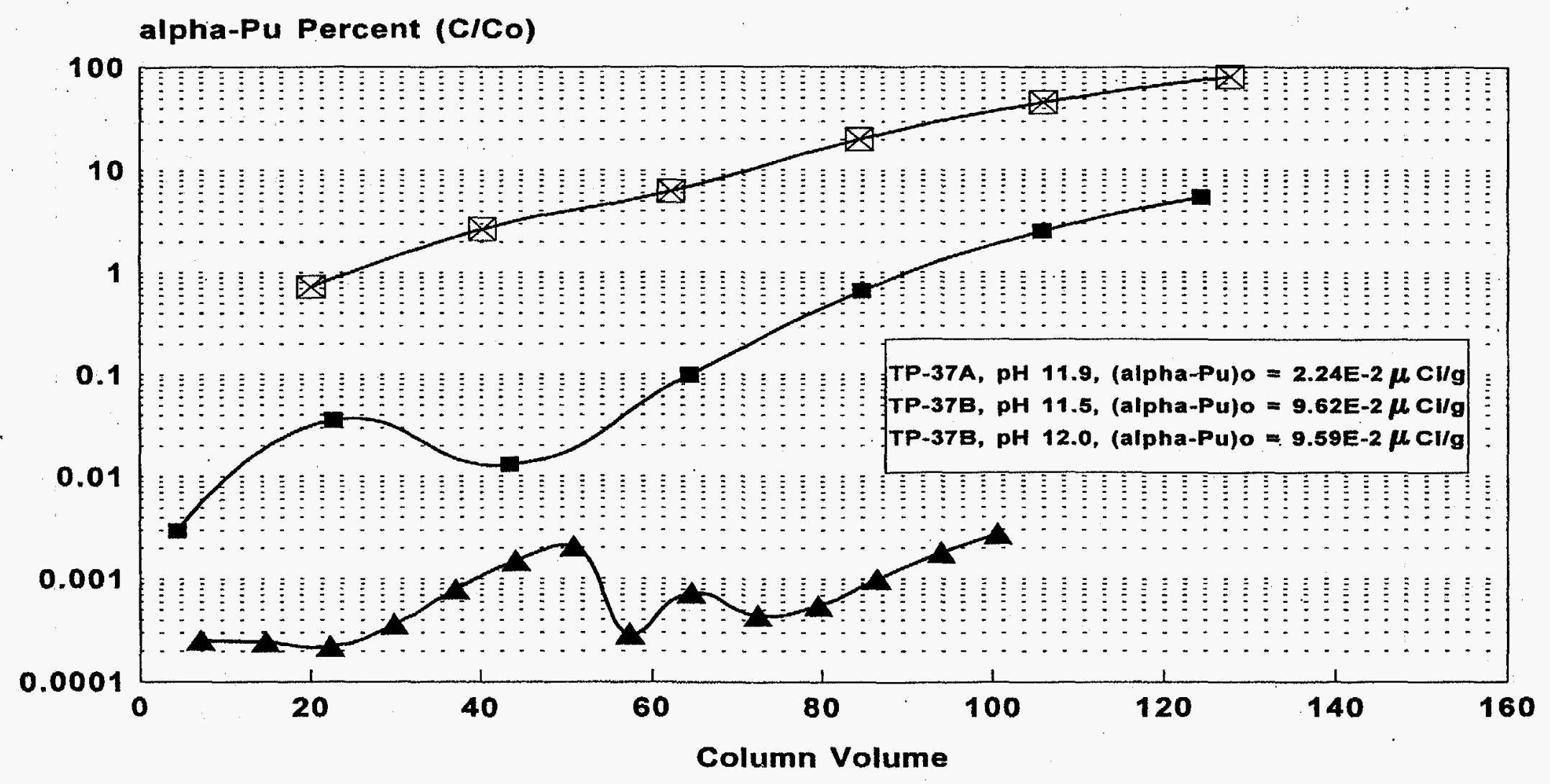

TP-037B (pH 11.6) - TP-037B (pH 12.0) 4 TP-037A (pH 11.9)

SINGLE TIE-96 COLUMN

COLUMN TEMPERATURE 10 DEGREE CELSIUS

Figure 14. Breakthrough $\left(\mathrm{C} / \mathrm{C}_{0}\right)$ Curve for allpha-Pu, Different $\mathrm{pHs}$, and Single TIE-96 Column 


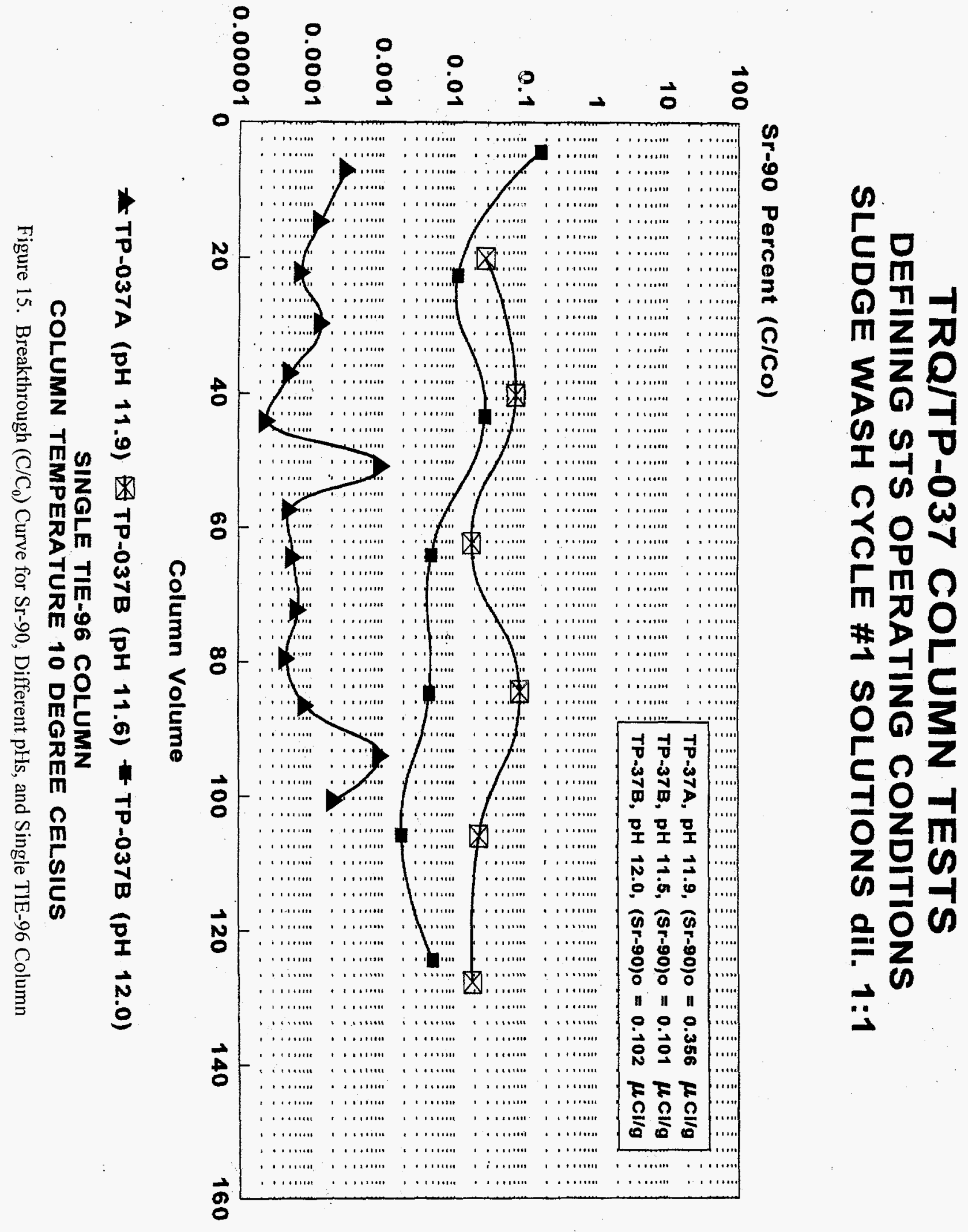




\subsection{Comparison to TP-037A}

The results from TP-037A are also provided in Figures 13, 14, and 15 to show a direct comparison between the single-column tests of TIE-96. DFs for Cs- 137 were 100,000 at $50 \mathrm{cv}$ and 500 at $100 \mathrm{cv}$. DFs for alpha-Pu were 50,000 at $50 \mathrm{cv}$ and 40,000 at $100 \mathrm{cv}$. The DF for Sr-90 was above 300,000 throughout the duration of the tests. The results have shown that TIE-96 at low process temperatures and within a $\mathrm{pH}$ of 11.5 to $12.0 \mathrm{can}$ simultaneously remove Cs-137, alpha-Pu, and Sr-90 from diluted Tank 8D-2 sludge wash one solutions. This is an advantageous result because the STS historically has operated at low temperatures to maximize Cs-137 removal and minimize zeolite consumption.

\subsubsection{TRQ/TP-037B Part 2}

\subsection{Column Feed Solution Flow Rate}

The actual temperature of the $10^{\circ} \mathrm{C}$ column was sustained at an average of $10.6 \pm 0.7^{\circ} \mathrm{C}$ during the test. The temperature of the cell temperature column averaged $28.9^{\circ} \mathrm{C}$ for the duration of the test, with a temperature range of 28.5 to $29.3^{\circ} \mathrm{C}$. The column feed solution flow rate was calculated to be $0.51 \mathrm{cv} / \mathrm{hr}$ for the $10^{\circ} \mathrm{C}$ test and $0.50 \mathrm{cv} / \mathrm{hr}$ for the $26^{\circ} \mathrm{C}$ test.

\subsection{Column Decontamination Factor (DF)}

$D F$ is defined as the reciprocal of the $\mathrm{C} / \mathrm{C}_{\mathrm{o}}$ or the numerical value of the concentration of the influent radionuclide to the concentration of the radionuclide leaving the column. Each TIE-96 column effluent was collected at 24-hour intervals and analyzed for $\mathrm{Cs}-137$, alpha- $\mathrm{Pu}$, and $\mathrm{Sr}-90$. Breakthrough $\left(\mathrm{C} / \mathrm{C}_{\mathrm{o}}\right)$ curves are provided for $\mathrm{Cs}-137$, alpha-Pu, and $\mathrm{Sr}-90$ in Figures 16,17, and 18, respectively. A summary of the decontamination factors from this test is provided in Table 15.

\section{$\underline{10}^{\circ} \underline{\mathrm{C} \text { Column Test }}$}

The DF for Cs-137 was greater than 3 million after 50 and $100 \mathrm{cv}$; greater than 400,000 after $150 \mathrm{cv}, 36,000$ after $200 \mathrm{cv}$; and 3,300 after $250 \mathrm{cv}$. DF for alpha-Pu was 6,600 after $50 \mathrm{cv} ; 3,300$ after $100 \mathrm{cv} ; 330$ after 150 $\mathrm{cv} ; 160$ after $200 \mathrm{cv}$; and 80 after $250 \mathrm{cv}$. DF for Sr-90 was greater than or equal to 100 for the duration of the test.

\section{Cell Temperature Test}

The DF for Cs-137 was greater than 6 million after $50 \mathrm{cv}$; 1 million after $100 \mathrm{cv}$; greater than 100,000 after $150 \mathrm{cv} ; 125$ after $200 \mathrm{cv}$; and 5 after $250 \mathrm{cv}$. DF for alpha-Pu was 12,500 after $50 \mathrm{cv} ; 3,300$ after $100 \mathrm{cv}$; 4,000 after $150 \mathrm{cv} ; 5,700$ after $200 \mathrm{cv}$; and 1,000 after $250 \mathrm{cv}$. DF for Sr-90 was greater than or equal to 100 for the duration of the test. The results have shown that IE-96 and TIE-96 columns in series can simultaneously remove $\mathrm{Cs}-137$, alpha-Pu, and Sr-90 from diluted Tank 8D-2 sludge wash one solutions. Lower temperatures increase the amount of Cs-137 removal from the sludge wash solution. This is an advantageous result because the STS operates at low temperatures to maximize Cs-137 removal and minimize zeolite consumption. 

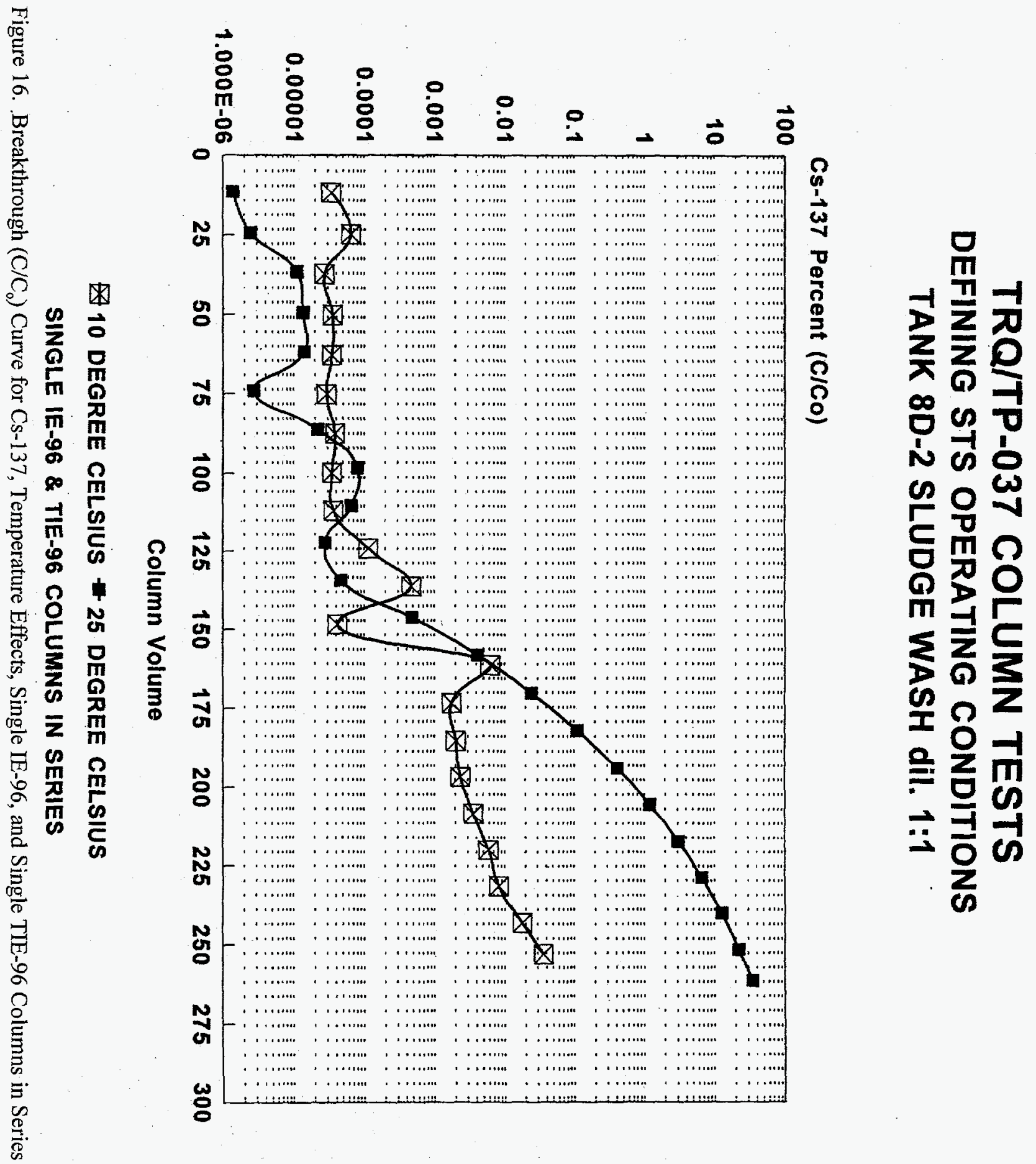

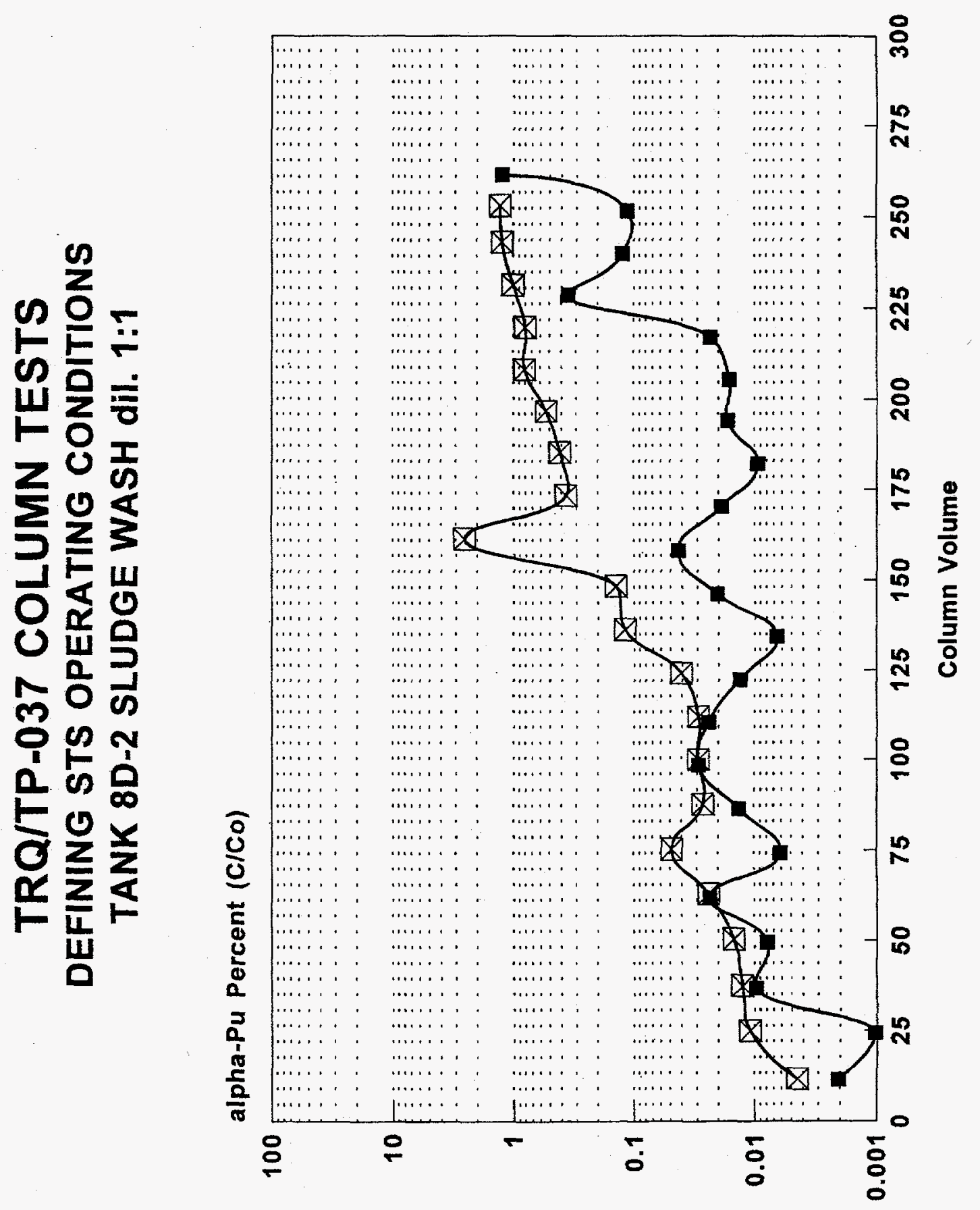


\section{TRQ/TP-037 COLUMN TESTS DEFINING STS OPERATING CONDITIONS \\ TANK 8D-2 SLUDGE WASH dil. 1:1}

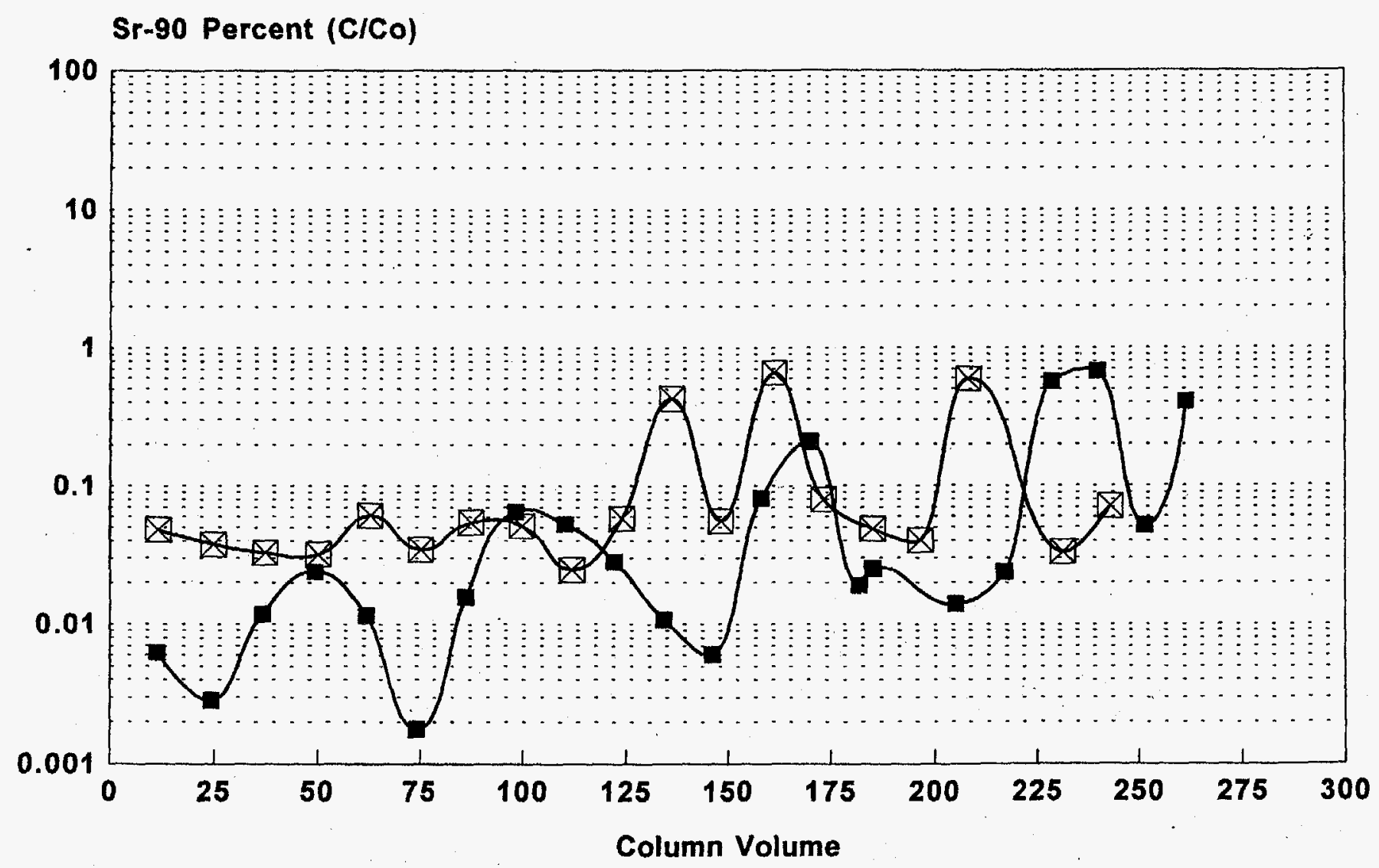

10 DEGREE CELSIUS 25 DEGREE CELSIUS

SINGLE IE-96 \& TIE-96 COLUMNS IN SERIES

Figure 18. Breakthrough $\left(\mathrm{C} / \mathrm{C}_{\mathrm{o}}\right)$ Curve for Sr-90, Temperature Effects, Single IE-96, and Single TIE-96 Columns in Series 
Table 15. Summary of Decontamination Factors for TSR-037B Part 2 Tank 8D-2 Sludge Wash Cycle 1, Diluted 1:1, with Single IE-96 and TIE-96 Zeolite Columns in Series

\begin{tabular}{|c|c|c|c|c|c|}
\hline \multicolumn{6}{|c|}{ Cs-137 Decontamination Factor } \\
\hline Test & $\underline{50 \mathrm{cv}}$ & $100 \mathrm{cv}$ & $\underline{150 \mathrm{cV}}$ & $\underline{200 \mathrm{cV}}$ & $\underline{250 \mathrm{cV}}$ \\
\hline $10^{\circ} \mathrm{C}$ & $3 E+06$ & $3 \mathrm{E}+06$ & 400,000 & 36,000 & 2,800 \\
\hline $26^{\circ} \mathrm{C}$ & $6 \mathrm{E}+01$ & $1 \mathrm{E}+06$ & 100,000 & 125 & 5 \\
\hline \multicolumn{6}{|c|}{ alpha-Pu Decontamination Factor } \\
\hline Test & $\underline{50 \mathrm{cV}}$ & $100 \mathrm{cv}$ & $150 \mathrm{cv}$ & $\underline{200 \mathrm{cV}}$ & $\underline{250 \mathrm{cV}}$ \\
\hline $10^{\circ} \mathrm{C}$ & 6,600 & 3,300 & 330 & 160 & 80 \\
\hline $26^{\circ} \mathrm{C}$ & 12,500 & 3,300 & 4,000 & 5,700 & 1,000 \\
\hline \multicolumn{6}{|c|}{ Sr-90 Decontamination Factor } \\
\hline Test & $\underline{50 \mathrm{cV}}$ & $100 \mathrm{cv}$ & $\underline{150 \mathrm{cv}}$ & $\underline{200 \mathrm{cv}}$ & $250 \mathrm{cv}$ \\
\hline $10^{\circ} \mathrm{C}$ & 2,800 & 2,000 & 2,200 & 1,000 & 5,800 \\
\hline $26^{\circ} \mathrm{C}$ & 4,000 & 1,600 & 10,000 & 6,600 & 1,000 \\
\hline
\end{tabular}

\subsubsection{Observations and Discussion of Results}

\subsubsection{TP-037B Part 1}

Pertinent information derived from TP-037B Part 1 has shown that at $\mathrm{pH}$ levels of 12.0, alpha-Pu removal is substantially improved over a comparable feed solution at a $\mathrm{pH}$ of 11.6 . Both TP-037B pH tests did have comparable feed alpha-Pu concentrations; 0.0959 and $0.0962 \mu \mathrm{Ci} / \mathrm{g}$ for the $\mathrm{pH} 12.0$ and $\mathrm{pH} 11.6$ solutions, respectively. Figure 17 shows the breakthrough curves for alpha-Pu. The lower the curve, the better the removal efficiency. The $\mathrm{pH} 11.5$ curve is the highest of all the curves, demonstrating that lower $\mathrm{pH}$ will not improve removal efficiency. When comparing the results of these two TIE-96 column tests to the results from TP-037A (Figure 14), it is important to note that the alpha-Pu in the TP-037B feed solutions were approximately 4 times greater than that of the feed solution used in TSR-037A. One would then expect that the alpha-Pu breakthrough would occur sooner with a solution at a higher concentration. After $100 \mathrm{cv}$ in TP037A, the outlet concentration is approximately the same as TP-037B, pH 12.0 after $25 \mathrm{cv}$. One would then expect that if the concentration and column volumes from TP-037A were corrected to this point, the two breakthrough curves should trend the same with additional processing. The results from this part of the test have shown that samples of the actual TIE-96 used in STS operations at process temperatures of $10 \pm 2^{\circ} \mathrm{C}$ and $\mathrm{pH}$ range of 11.5-12.1 can simultaneously remove Cs-137, alpha-Pu, and Sr-90 from diluted sludge wash 1 solutions. 


\subsubsection{TP-037B Part 2}

One observation not seen in other A\&PC column tests was the formation of a light colored apparent precipitate on top of the $10^{\circ} \mathrm{C}$ TIE- 96 column after 6 days of flowthrough testing. This precipitation did disappear after 7 additional days. Both the IE-96 columns, one at cell temperature and one at $10^{\circ} \mathrm{C}$, appeared to have darkened in color as the test progressed. These observations had no apparent impact on the test results.

Due to the low feed-flow rates inherent with the test apparatus and the amount of analysis required, sample collection was restricted to once every 24 hours. During the $10^{\circ} \mathrm{C}$ test, the $\mathrm{pH}$ on the column effluent was 9.13 after 22 hours, 11.7 after 46 hours, and 12.2 after 70 hours. After this point, the pH of the column effluent and feed were equivalent. During the $26^{\circ} \mathrm{C}$ test, the $\mathrm{pH}$ was 8.83 after 22 hours, 10.9 after 46 hours, and 12.1 after 70 hours. After this point, the $\mathrm{pH}$ of the column effluent and feed were equivalent. The low initial $\mathrm{pH}$ is attributed to the demineralized water heel remaining in the columns that is being displaced or flushed out by the sludge wash feed solution. Recirculation solutions that were subsequently used in this test were prepared from effluent collected during the preceding sludge wash processing segments, diluted until the sodium concentration was less than $1,500 \mathrm{ppm}$.

During the previously conducted laboratory column test (TP-042, section 4.5), the $\mathrm{pH}$ of both the recirculation solution and column effluent dropped with time. This was apparently due to absorption of $\mathrm{CO}_{2}$ from the incell air and the low salt concentration of the solution. This could have a detrimental effect; it could create a situation during a recirculation segment in STS were the Pu removed during sludge wash processing could form soluble Pu-carbonate compounds, dissolving into solution from the TIE-96 column.

In this test, in order to minimize the influence of the $\mathrm{CO}_{2}$, laboratory air was bubbled through a $10 \% \mathrm{NaOH}$ solution for removal of the $\mathrm{CO}_{2}$ from the air. This scrubbed air was then used to blanket the void space in the sealed recirculation feed bottles. This did not entirely prevent an eventual $\mathrm{pH}$ drop, but the drop wasn't as large as in the previous tests. The $10^{\circ} \mathrm{C}$ recirculation feed solution showed a drop in $\mathrm{pH}$ from 11.1 to 10.9 over 8 days; the cell recirculation feed solution showed a drop in $\mathrm{pH}$ from 10.9 to 10.1 , also over an 8-day period.

The $\mathrm{pH}$ of the $10^{\circ} \mathrm{C}$, recirculation solution column effluent dropped slowly over 4.5 days to a $\mathrm{pH}$ of 9.09 , returning back to the feed solution value of 11.1 after 8 days. The $\mathrm{pH}$ of the cell recirculation solution column effluent dropped slowly over 6 days to a $\mathrm{pH}$ of 10.1 , then started to slowly increase.

There was an apparent elution of the Pu from the TIE-96 columns during recirculation, but this represented only $0.11 \%$ of the Pu removed by the $10^{\circ} \mathrm{C}$ TIE- 96 column during sludge wash processing, and $0.025 \%$ of the $\mathrm{Pu}$ removed by the cell temperature column during sludge wash processing.

The results from TRQ-037B Part 2 have shown that a single column of IE-96 in series with TIE-96 at process temperatures of $10 \pm 2^{\circ} \mathrm{C}$ and $25 \pm 5^{\circ} \mathrm{C}$ with a $\mathrm{pH}$ of 12.3 can simultaneously remove Cs-137, alpha-Pu, and Sr-90 from actual diluted Tank 8D-2 sludge wash 1 solutions. As expected, Figure 16 indicates that lower operating temperatures increase Cs-137 removal efficiency. Conversely, Figure 17 indicates better alpha-Pu removal from the sludge wash solution at the higher cell temperature. Initial column efficiency (DF) is related to such effects as the length-to-depth ratio of the zeolite bed, channeling, flow rate, etc. Zeolite capacity is expected to have an effect, but this may be obscured by others. Cs-137 capacity of a column is a chemical equilibrium effect not related to the effects contributing to the initial efficiency.

The Sr-90 breakthrough curves show apparent random scatter. Unlike the $\left(\mathrm{C} / \mathrm{C}_{0}\right)$ curve for $\mathrm{Cs}-137$ and alpha$\mathrm{Pu}$, the values for $\mathrm{Sr}-90$ fluctuated within a range throughout the test. The source of this scatter could be attributed to analytical limitations. 
There has been a concern that the zeolite in the columns could fuse or cake to prevent the dumping of the zeolite from the columns after the processing of high $\mathrm{pH}$ solutions during sludge wash processing. Previous high $\mathrm{pH}$ testing, using synthetic sludge wash solutions (see Section 4.6) at PNL, have demonstrated that this should not occur. To assess the potential for this phenomenon after processing actual sludge wash solution, at the conclusion of the TP-0378B column test portion, all four columns were filled with demineralized water and then inverted to determine the ease or difficultly of emptying or dumping the zeolite from the columns. IE-96 and TIE-96 zeolites from both the cell temperature and $10^{\circ} \mathrm{C}$ tests were easily dumped from the columns.

The top $1 / 3$ to $1 / 2$ of each column flowed freely with inversion, the remaining portions required slight tapping to initiate the flow. There was no observable caking, gelling, or clumping that prevented the columns from being dumped. Trapped air bubbles in the columns were observed, but previous mass spectrometric analysis on similar bubbles formed during a water soak of TIE-96 samples has shown this gas to be air. The same phenomenon was obtained during cold testing with a spare IE-96 column.

\subsection{WVNS-TSR-042 -- "STS Column-loading Verification with TIE-96 Zeolite"11}

The purpose of the test was to verify effective Cs-137 and Pu removal from ion-exchange columns in series that reflect the anticipated operating mode of STS during sludge wash processing. The test simulated STS operations in the following aspects:

- Three-column series process initially consisting of two IE-96 columns followed by a third TIE-96 column. The IE-96 came from warehouse stock reserved for STS use. The TIE-96 came from the UOP production lot identified for use in IRTS processing campaign \#22, which was the first sludge washing processing. Table 16 lists the amount of zeolite charged to each column. An In-cell schematic of the test apparatus is provided in Figure 19.

- Operation approximated the full-scale STS process: column outlet temperature $\approx 12^{\circ} \mathrm{C}$, flow rate 0.5 $0.6 \mathrm{cv} / \mathrm{hr}$ (corresponds to $4-5 \mathrm{gpm}$ in STS), and dilution to $11.8-14.8 \% \mathrm{TDS}$.

- Sludge wash feed solutions were prepared from actual Tank 8D-2 sludge samples and supernatant, mixed to the ratio existing in the tank, and adjusted with caustic to the same criteria as the sludge wash operation.

- The STS recirculation mode between processing periods was approximated by switching from a "sludge wash" feed to a "recirculation" feed. The recirculation solution was prepared by diluting decontaminated sludge wash solution to $<1,500 \mathrm{ppm}$ sodium, as is done in the operation of STS, by flushing the system with demineralized water following a processing campaign.

- Lead column change-out was performed when the Cs-137 concentration in the effluent corresponded to the maximum observed during IRTS campaigns \#1 to \#21. When the lead column was removed, the second (IE-96) and third (TIE-96) columns became the new lead and second columns, respectively, and a fresh IE-96 column was added in the third position. 
Table 16. WVNS TRQ/TP-042

Zeolite Contained in the Test Columns

\begin{tabular}{lcccc}
\hline Column Number & Zeolite (grams) & Moisture (percent) & Density (g/ml) & $\frac{\text { cv(ml) }}{1.30}$ \\
1 (IE-96) & 1.3435 & 2.3 & 0.842 & 1.60 \\
2 (IE-96) & 1.3155 & 2.3 & 0.842 & 1.56 \\
3 (TIE-96) & 1.3114 & 10.2 & 0.923 & 1.42 \\
4 (IE-96) & 1.3065 & 2.3 & 0.842 & 1.55 \\
\hline
\end{tabular}




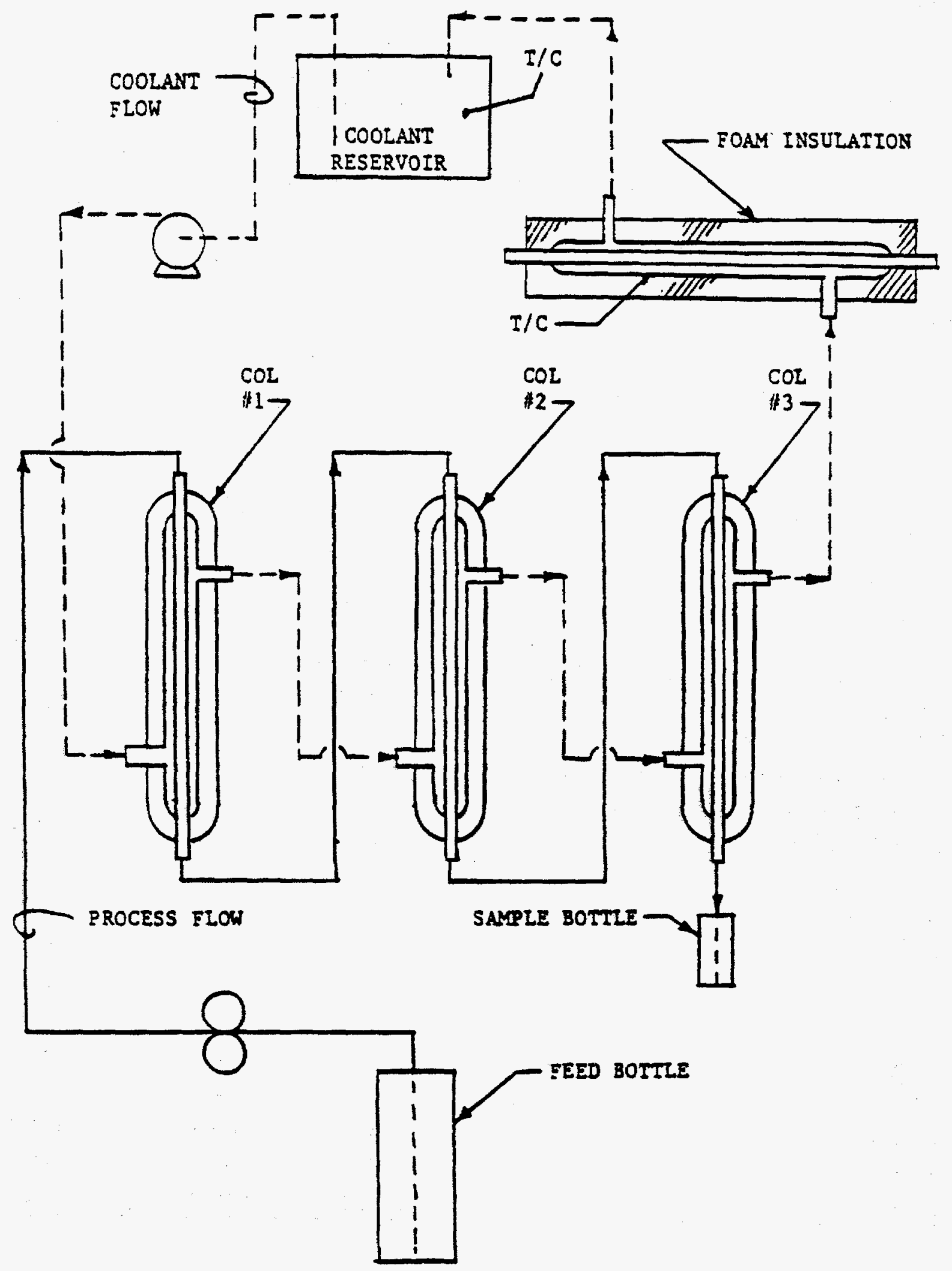

Figure 19. In-cell Test Set-up Schematic 


\subsubsection{Test Summary}

This test used glass columns that were double-jacketed which provided insulation and allowed for visual observation of the condition of the zeolite (Figure 20). These visual observations were needed based on PNL's observation of a deposition on TIE-96 columns (see section 4.6). The deposits observed during PNL's tests with a simulated sludge wash cycle 1 solution at $\mathrm{pH} 12.5$ were reported to be aluminum which re-dissolved as the test progressed. The small amount of the deposit that remained on the second column throughout the PNL test was analyzed as calcium phosphate. No such deposition was observed during TP-042. Feed solution was prepared from radioactive sludge wash solutions prepared under other test procedures. The sludge wash solutions were diluted 1:1 with water prior to use as feed in this test. Analyses of the three solutions used in TP-042 are given in Table 17. Selected nonradioactive species are shown. The sequence of test procedure 042 was as follows:

- IRTS Campaign \#22 sludge wash processing simulation, with one recirculation period ("Recirculation $\# 1 ")$ just prior to column change-out

- Column change-out; consisting of removing the lead ion-exchange column, that has been fully loaded with Cs-137 and adding a fresh IE-96 zeolite-filled column in the last position, behind the two remaining columns. This creates a column sequence of IE-96, TIE-96, and IE-96 zeolite

- IRTS Campaign \#23 sludge wash processing simulation, followed by extended recirculation ("Recirculation \#2") after the lead column has been fully loaded with Cs-137

- "True Recirculation," with column effluent directly used as feed

- $\mathrm{Na}_{2} \mathrm{CO}_{3} / \mathrm{NaHCO}_{3}$ solution rinse of the TIE-96 column.

\begin{tabular}{lccc}
\hline \multicolumn{4}{c}{$\begin{array}{c}\text { Table 17. WVNS TRQ/TP-042 } \\
\text { Sludge Wash Feed Solution Analysis }\end{array}$} \\
\hline Analysis & TP-036(a) & TP-036(b) & TP-039 \\
pH & 11.9 & 12.1 & 12.0 \\
Total Dissolved Solids (TDS) (g-salt/g-solution) & $\approx 0.118$ & $\approx 0.118$ & $\approx 0.148$ \\
Density $(\mathrm{gm} / \mathrm{mL})$ & 1.076 & 1.078 & 1.100 \\
alpha-Pu $(\mu \mathrm{Ci} / \mathrm{g})$ & 0.0224 & 0.0225 & 0.0967 \\
$\mathrm{Sr}-90(\mu \mathrm{Ci} / \mathrm{g})$ & 0.356 & 0.282 & 0.0471 \\
$\mathrm{Cs}-137(\mu \mathrm{Ci} / \mathrm{g})$ & -435 & 409 & 435 \\
$\mathrm{Al}(\mu \mathrm{g} / \mathrm{g})$ & -- & 446 & 501 \\
$\mathrm{~B}(\mu \mathrm{g} / \mathrm{g})$ & -- & 32.0 & 25.6 \\
$\mathrm{Cr}(\mu \mathrm{g} / \mathrm{g})$ & 110 & 111 & 127 \\
$\mathrm{~K}(\mu \mathrm{g} / \mathrm{g})$ & -- & 843 & 1080 \\
$\mathrm{Mo}(\mu \mathrm{g} / \mathrm{g})$ & - & 30.9 & 39.0 \\
$\mathrm{Na}(\mu \mathrm{g} / \mathrm{g})$ & 31,000 & 32,000 & 43,000 \\
$\mathrm{P}(\mu \mathrm{g} / \mathrm{g})$ & 85.7 & 93.5 & 121 \\
$\mathrm{Cs} / \mathrm{Na}$ & $1.263 \mathrm{E}-4$ & $1.151 \mathrm{E}-4$ & $9.108 \mathrm{E}-5$ \\
\hline
\end{tabular}




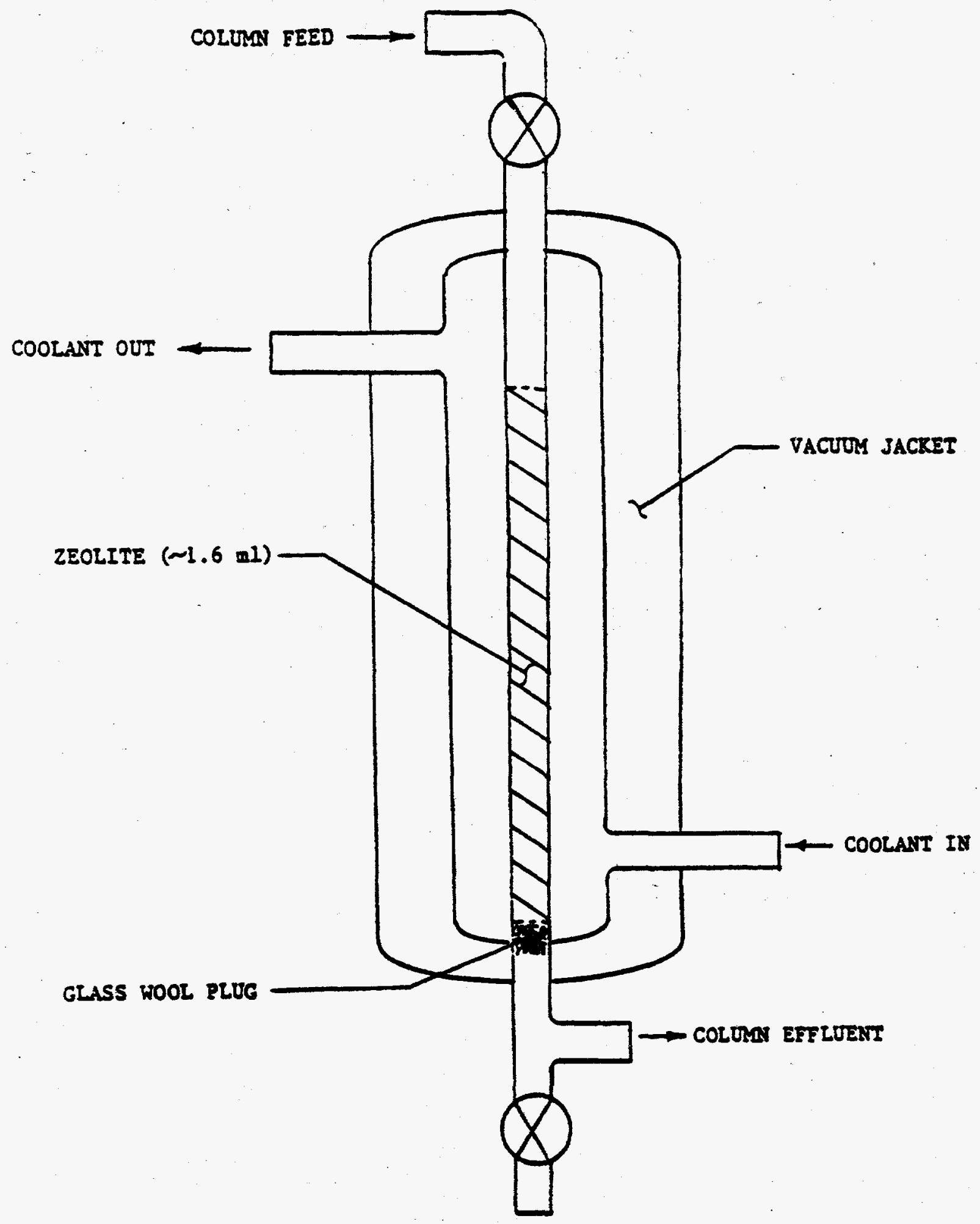

Figure 20. Laboratory Ion-exchange Column Design 
The Campaign \#22 simulation initially used the two sludge wash solutions ( $a$ and $b$ ) prepared under WVNSTP-036 until they were consumed, at which time the solution was changed to that prepared under WVNS-TP039. The solutions used in recirculation \#1 and \#2 segments were prepared from effluent collected during the preceding sludge wash processing segments and diluted until the sodium concentration was less than 1,500 ppm. The recirculation \#1 and \#2 techniques switched feed bottles from the sludge wash solution to the recirculation solution.

The "true recirculation" solution consisted of effluent collected during the preceding recirculation \#2 segment. No dilution was made to this solution and it was continuously recirculated from the last column effluent to the first column feed. Only intermittent samples from this closed loop test set-up were taken for analyses. The "bicarbonate" recirculation used a mixture of $0.01 \mathrm{M} \mathrm{Na}_{2} \mathrm{CO}_{3}$ solution and $0.01 \mathrm{M} \mathrm{NaHCO}_{3}$ solution as the column feed. Analyses of the various recirculation solutions are shown in Table 18. The flow rates for the various test segments, taken from Figure 21 data, are shown in Table 19. Two different values of $\mathrm{cv} / \mathrm{hr}$ are given in Table 19. The cv/hr-Cs-137 is based on the volume of IE-96 in the lead column. The cv/hr-Cs- 137 remained the same after column change-out despite a slight reduction in flow rate because of the coincidental slight reduction in volume of the new lead column. The cv/hr-Pu is based on the volume of TIE-96. Results of the testing are shown in Figures 22, 23, and 24 for Cs-137, Pu, and Sr-90, respectively. The criteria for column change-out was a Cs-137 concentration exceeding $0.15 \mu \mathrm{Ci} / \mathrm{ml}$, which corresponds to the maximum curies of Cs-137 per drum of cement currently in the Drum Cell. The $0.15 \mu \mathrm{Ci} / \mathrm{ml}$ value is higher than previously transferred to Tank 5D-15B during STS operations because sludge wash solution has more nonradioactive salts (e.g., from the caustic addition to Tank 8D-2); and because the solution will be concentrated to less than the $40 \%$ TDS target previously used (a 33\% TDS was assumed here).

\begin{tabular}{lccccc}
\hline \multicolumn{5}{c}{ Table 18. WVNS TRQ/TP-042 } \\
& Recirculating Solution Feed Composition & & \\
\hline \multirow{2}{*}{ Analysis } & Recirc. & Recirc. & Recirc. & True & $\underline{\text { Bicarb. }}$ \\
$\mathrm{pH}$ & $\# 1$ & $\underline{\# 2 \mathrm{a}}$ & $\underline{\# 2 \mathrm{~b}}$ & $\underline{\text { Recirc. }}$ & $\underline{\text { Recirc. }}$ \\
Total Dissolved Solids, $(\mathrm{g} / \mathrm{g})$ & $\approx 5.94 \mathrm{E}-3$ & $\approx 4.99 \mathrm{E}-3$ & $\approx 6.05 \mathrm{E}-3$ & $5.52 \mathrm{E}-3$ & $\approx 8.84 \mathrm{E}-4$ \\
Density $(\mathrm{gm} / \mathrm{mL})$ & $\approx 1.004$ & $\approx 1.004$ & $\approx 1.004$ & $\approx 1.004$ & $\approx 1.001$ \\
alpha-Pu $(\mu \mathrm{Ci} / \mathrm{g})$ & $1.03 \mathrm{E}-5$ & $1.05 \mathrm{E}-3$ & $1.40 \mathrm{E}-3$ & $1.01 \mathrm{E}-2$ & 0.0 \\
$\mathrm{Sr}-90(\mu \mathrm{Ci} / \mathrm{g})$ & $2.54 \mathrm{E}-6$ & $1.79 \mathrm{E}-4$ & $4.59 \mathrm{E}-4$ & $4.09 \mathrm{E}-4$ & 0.0 \\
$\mathrm{Cs}-137(\mu \mathrm{Ci} / \mathrm{g})$ & $1.75 \mathrm{E}-5$ & $3.92 \mathrm{E}-4$ & $5.64 \mathrm{E}-4$ & $1.59 \mathrm{E}-2$ & 0.0 \\
$\mathrm{Al}(\mu \mathrm{g} / \mathrm{g})$ & -- & 14.1 & 18.3 & - & 0.0 \\
$\mathrm{~B}(\mu \mathrm{g} / \mathrm{g})$ & -- & 0.896 & 0.935 & - & 0.0 \\
$\mathrm{Cr}(\mu \mathrm{g} / \mathrm{g})$ & -- & 3.56 & 4.84 & - & 0.0 \\
$\mathrm{~K}(\mu \mathrm{g} / \mathrm{g})$ & -- & 20.3 & 24.5 & - & 0.0 \\
$\mathrm{Mo}(\mu \mathrm{g} / \mathrm{g})$ & -- & 1.07 & 1.50 & -- & 0.0 \\
$\mathrm{Na}(\mu \mathrm{g} / \mathrm{g})$ & 1560 & 1220 & 1590 & -- & 276 \\
$\mathrm{P}(\mu \mathrm{g} / \mathrm{g})$ & - & 6.14 & 5.06 & - & 0.0 \\
$\mathrm{Cs} / \mathrm{Na}$ & $1.01 \mathrm{E}-10$ & $4.16 \mathrm{E}-9$ & $2.22 \mathrm{E}-9$ & -- & 0.0 \\
$\mathrm{CO} 3(\mu \mathrm{g} / \mathrm{g})$ & -- & -- & -- & -- & 600 \\
\hline
\end{tabular}




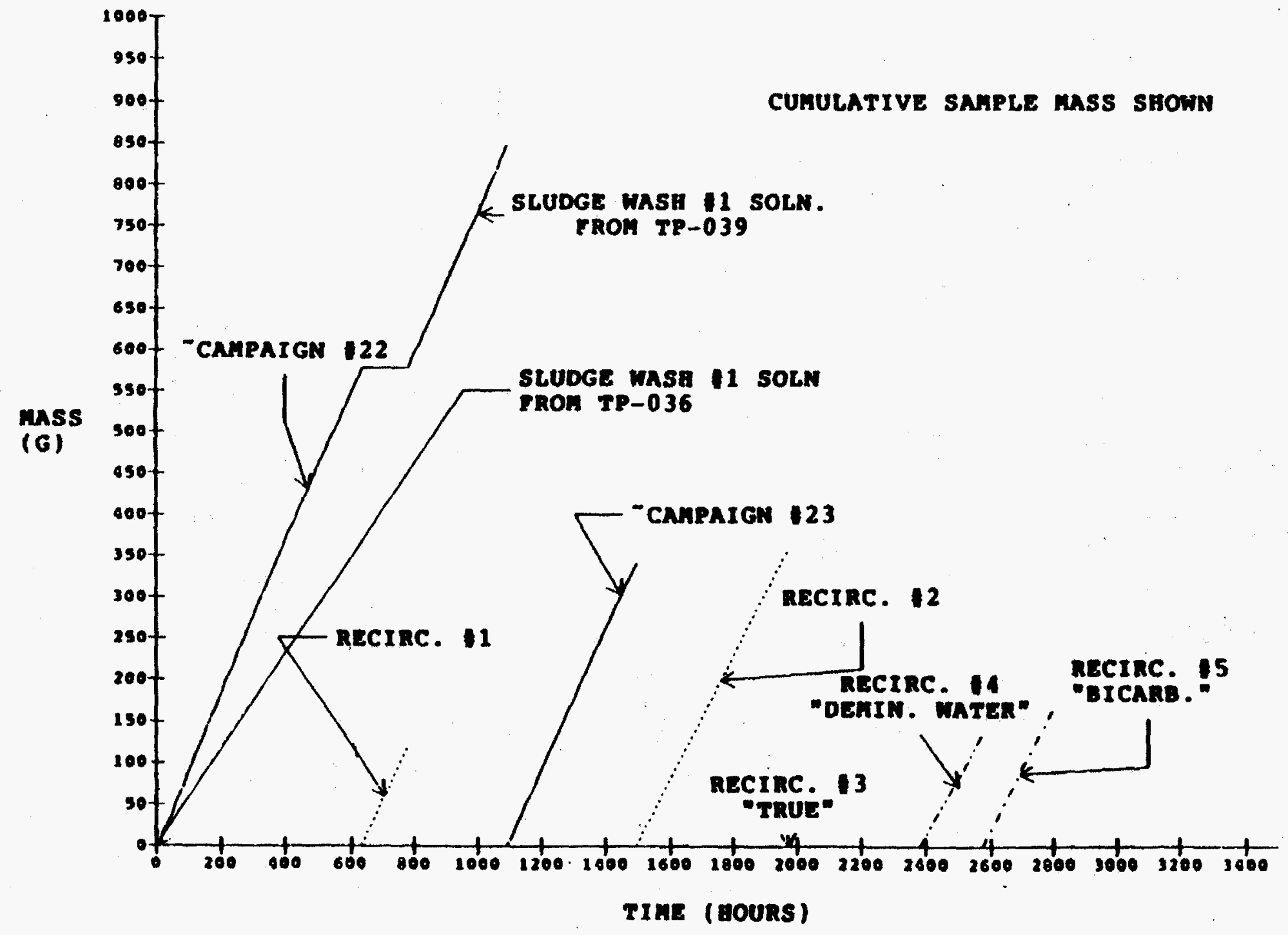

Figure 21. Process Flow Rate 


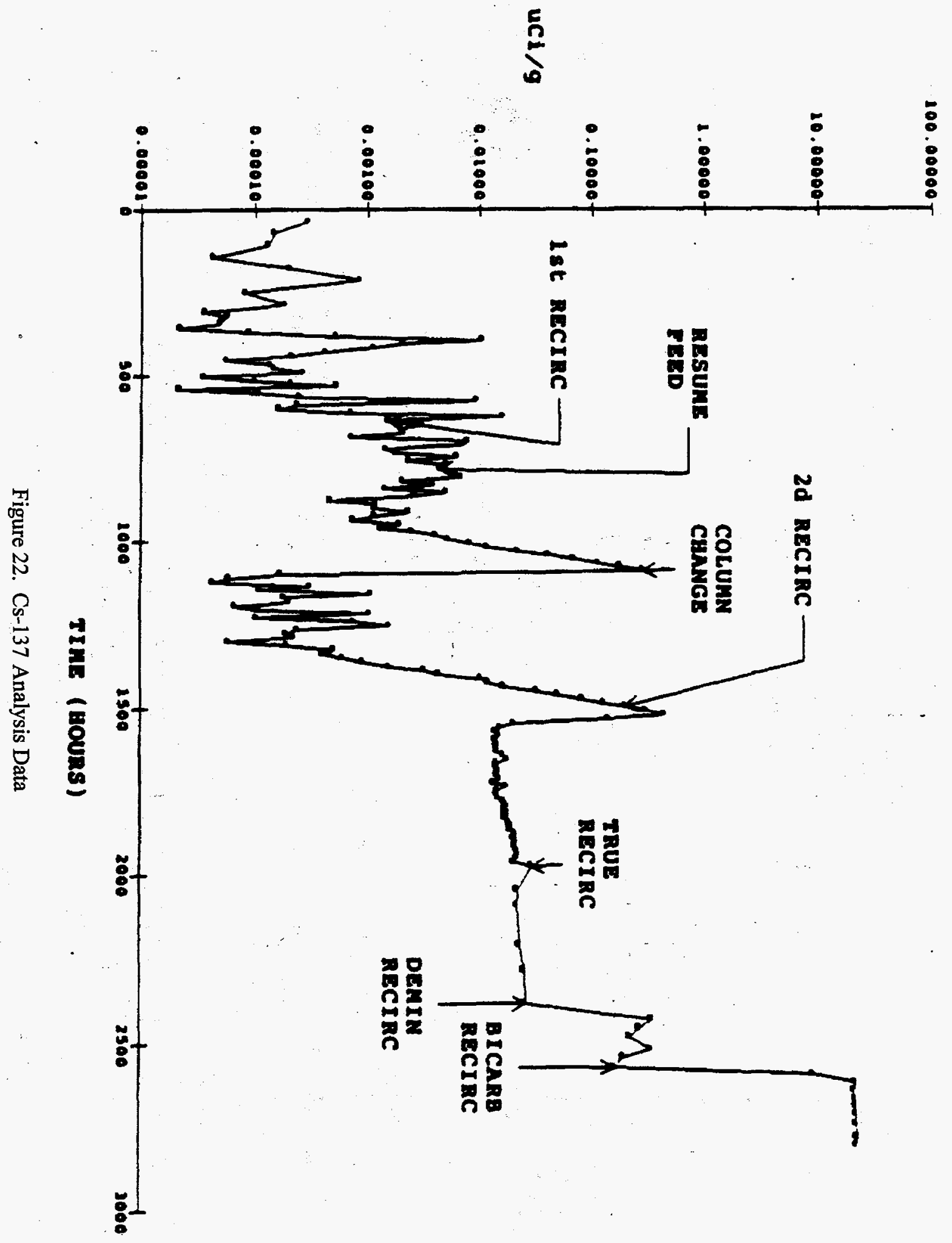




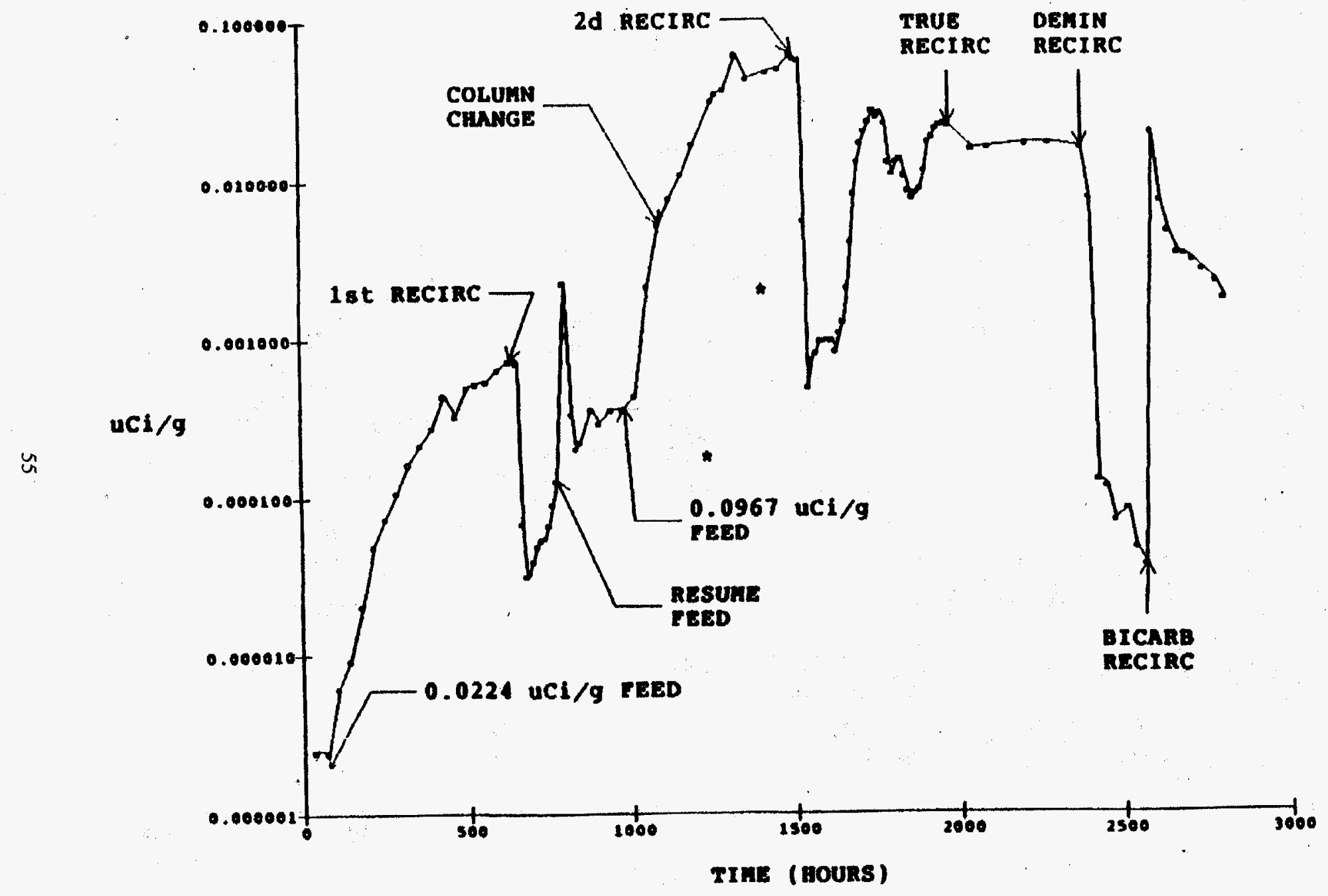

- OUTLIERs

Figure 23. Pu Analysis Data 


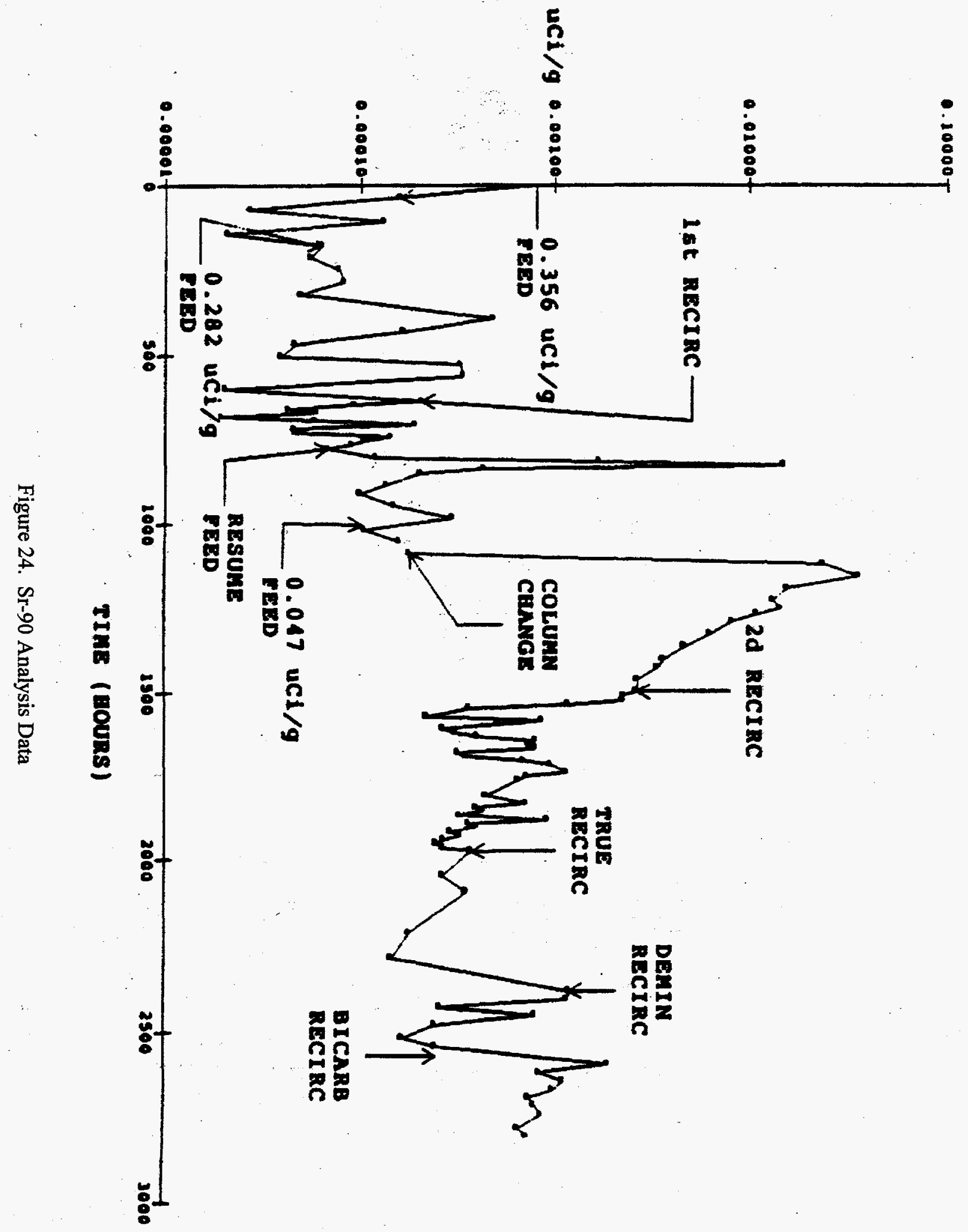


Table 19. WVNS TRQ/TP-042

Process Flow Rates

\begin{tabular}{lccc}
\hline Test Segment & $\underline{\mathrm{ml} / \mathrm{hr}}$ & $\frac{\mathrm{cv} / \mathrm{hr}-\mathrm{Cs}}{\mathrm{cv} / \mathrm{hr}-\mathrm{Pu}}$ \\
Estimated Campaign \#22 & 0.86 & 0.53 & 0.60 \\
Recirculation \#1 & 0.82 & 0.51 & 0.58 \\
Estimated Campaign \#22 & 0.79 & 0.49 & 0.56 \\
Estimated Campaign \#23 & 0.77 & 0.49 & 0.54 \\
Recirculation \#2 & 0.75 & 0.48 & 0.53 \\
"True" Recirculation & 0.74 & 0.48 & 0.52 \\
Demin. Water Rinse & 0.70 & 0.49 & 0.49 \\
Bicarbonate Rinse & 0.73 & 0.52 & 0.52 \\
\hline
\end{tabular}

\subsection{2 lon-exchange Column Test}

Breakthrough curves for $\mathrm{Cs}-137, \mathrm{Pu}$, and $\mathrm{Sr}-90$ are shown in Figures 25, 26, and 27, respectively. The recirculation periods were deleted from the curves for clarity. Concentration ratios shown are based on the feed analyses at the time of the effluent samples. Inspection of Figure 25 shows that Cs- 137 breakthrough was not apparently influenced by the recirculation period. Two additional Cs- 137 values are shown on Figure 25 that were not shown on Figure 22. These were one-time samples taken from the effluent of the lead and second columns when the initial lead column was changed out. The column change-out provided an opportunity to measure breakthrough from those individual columns. Intercolumn samples could not be routinely collected because the mass of the sample required for analyses was comparable to the entire flow through all three columns during a 12-hour period. The column changeout criteria for this test resulted in higher Cs-137 loading in the first and second columns than typically experienced during previous STS processing operations. The lead column effluent at the time of change-out was the same as the feed concentration. The second column effluent was essentially a 50\% breakthrough (see Figure 25 -- Triangle Data Point). This additional initial loading on the lead and second columns explains the apparent reduction in throughput seen during simulated campaign \#23, after the lead column was changed out.

The spike in the Pu breakthrough (Figure 26) after the first recirculation period was related to the decreasing $\mathrm{pH}$ during the period. There was a downward shift in the Pu breakthrough curve after the first recirculation segment. This resulted from a step change in the mechanism by which TIE-96 removes Pu. The Pu extracted from the TIE-96 zeolite and entering the solution during the recirculation segment was an insignificant fraction of that previously retained on the TIE-96 which precluded this from explaining the shift. The change in feed and the column change-out did not seem to influence the breakthrough curve. The continuation of the curve, despite a four-fold increase in feed concentration, indicated the mechanism responsible for $\mathrm{Pu}$ removal is dominated by equilibrium between the solution concentration and the Pu on the zeolite rather than by a solubility limit in the solution.

As with $\mathrm{Pu}$, the $\mathrm{Sr}-90$ spike after the recirculation period was related to the $\mathrm{pH}$ change of that segment. The change in feed composition did not significantly alter the breakthrough. There was an upward shift in the Sr-90 breakthrough curve after column change-out. A reduction in calcium entering the TIE-96 column due to less upstream IE-96 may have contributed to this. TIE-96 may remove Sr-90 by a mechanism that includes Sr90 co-precipitation with calcium. 


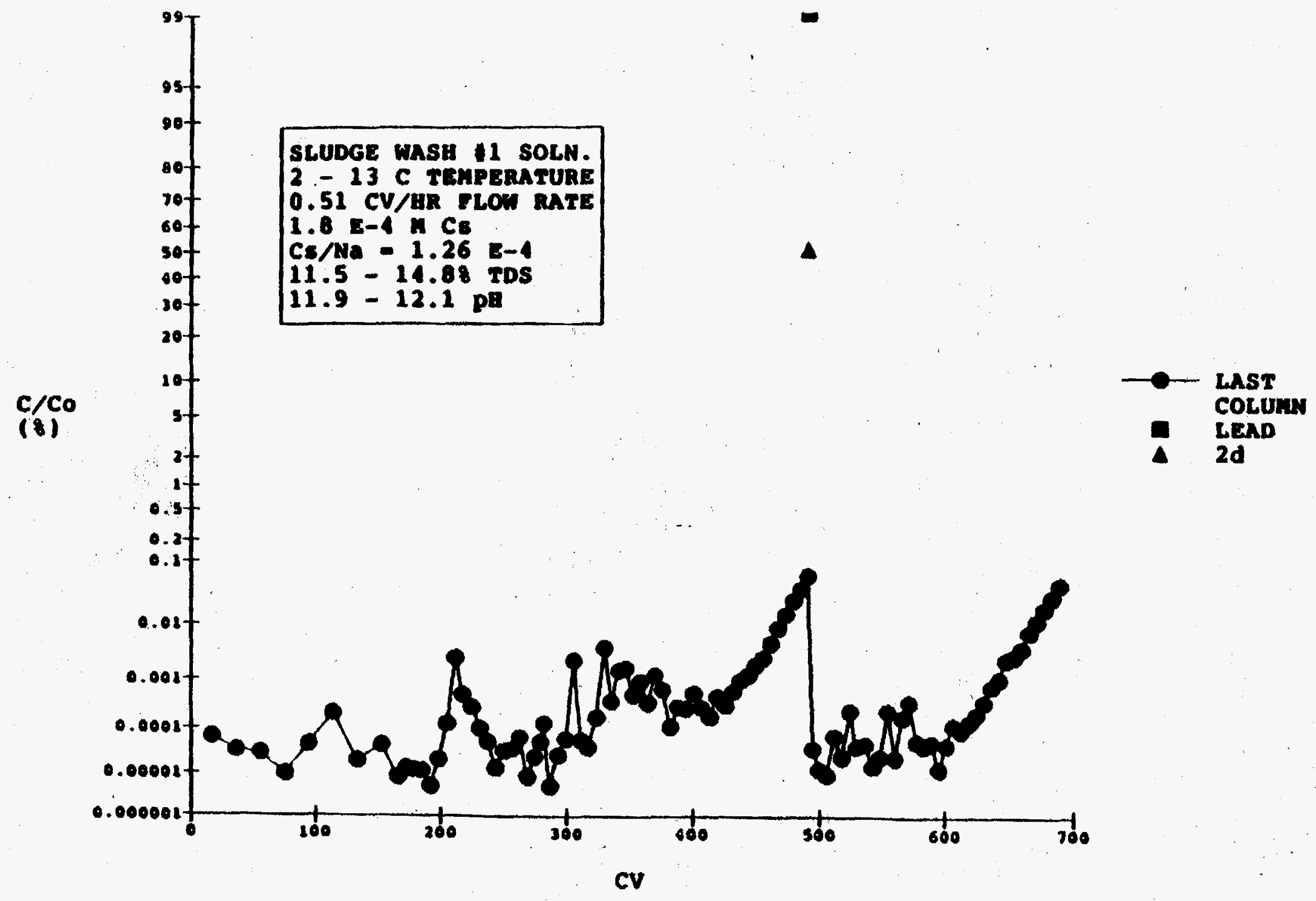




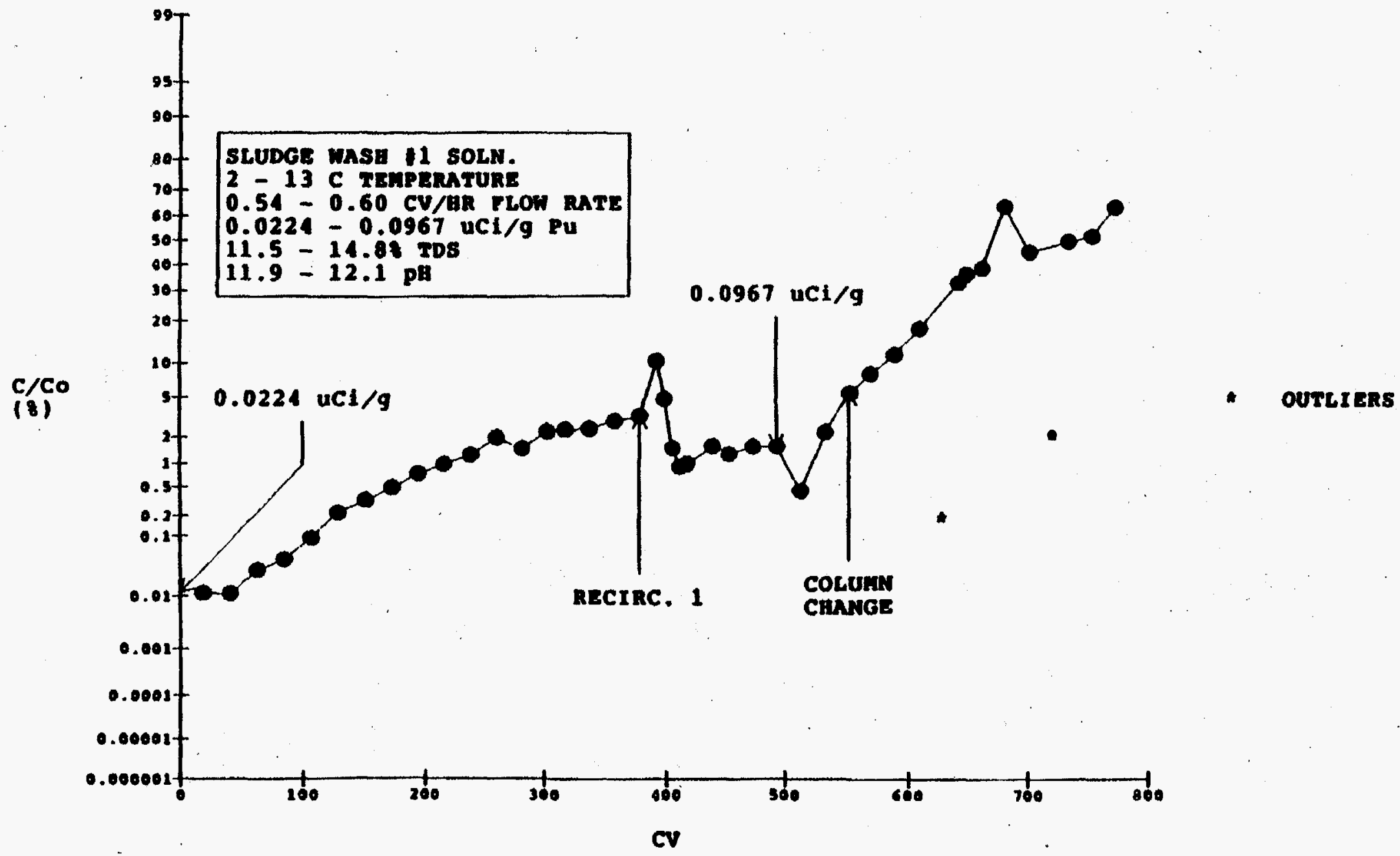

Figure 26. Pu Breakthrough 


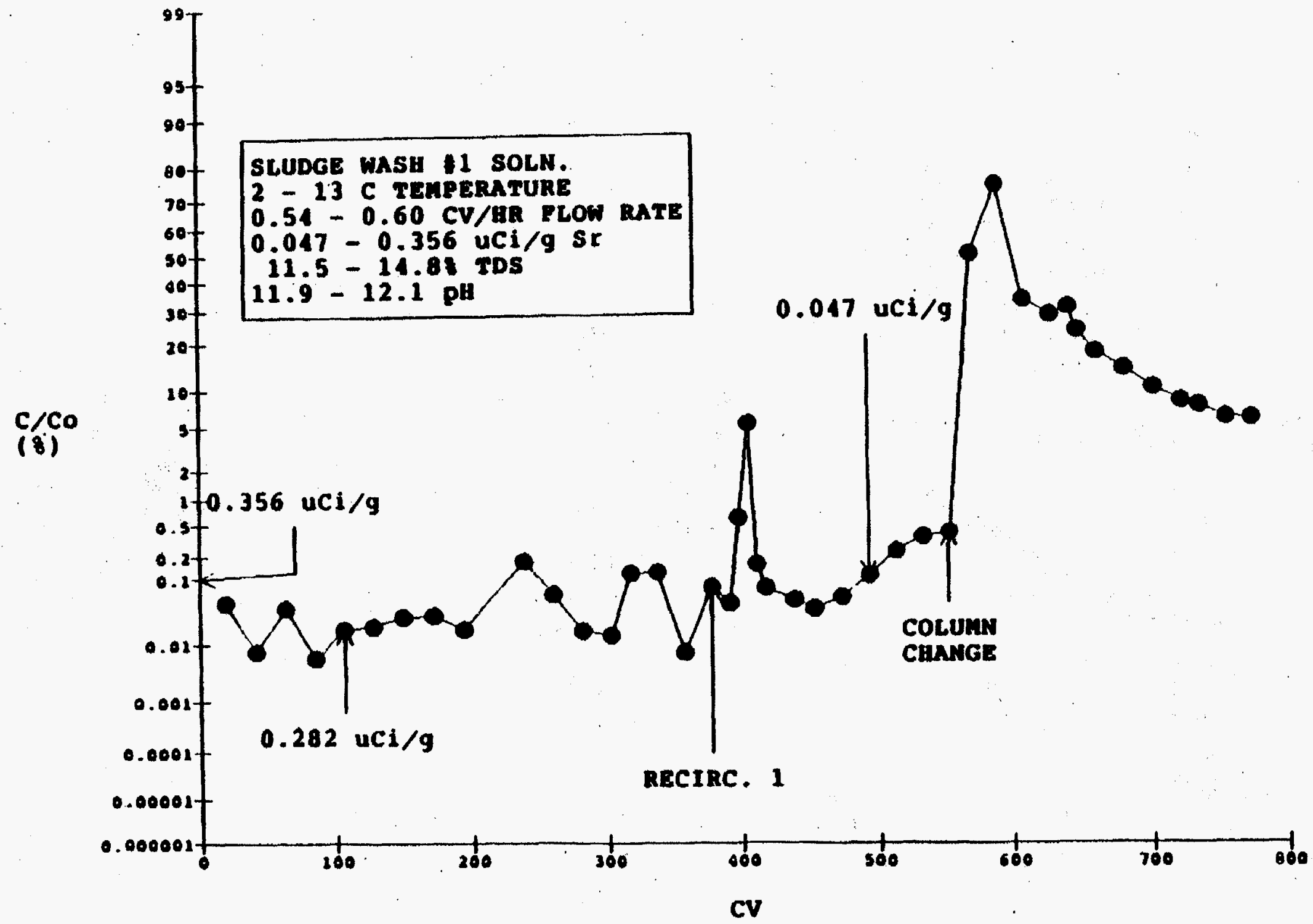

Figure 27. Sr-90 Breakthrough 


\subsubsection{Recirculation \#1 and \#2}

The $\mathrm{pH}$ of the recirculating solutions used in recirculation \#1 and \#2 dropped during the time they were feeding the columns. This was apparently due to absorption of $\mathrm{CO}_{2}$ from the In-cell air and the low salt concentrations of the solutions. The feed solutions for the test were not totally sealed from the cell atmosphere, allowing air to diffuse in the feed bottle air space. Table 20 shows the $\mathrm{pH}$ of the solutions before and after feeding the columns in their respective test segments. The re-analyses were not done immediately after the test segments, so there was opportunity for additional change in the solution after feeding stopped. Also, the feed bottles were not open to the ambient cell; they were partially sealed to minimize evaporative losses. The feed solution containers were all narrow-mouth borosilicate bottles with holes drilled through their plastic caps for insertion of the feed line. These two observations prevent use of the before and after analyses directly in data interpretation.

\begin{tabular}{lccc}
\hline \multicolumn{4}{c}{$\begin{array}{l}\text { Table 20. WVNS TRQ/TP-042 } \\
\text { Recirculating Solution pH Drop }\end{array}$} \\
\hline Recirculating Segment Solution & $\underline{\text { Initial pH }}$ & Intervening Days & $\underline{\text { Final pH }}$ \\
\#1 & 11.0 & 70 & 9.13 \\
\#2 Part a & 11.2 & 24 & 9.10 \\
\#2 Part b & 11.0 & 11 & 9.16 \\
\hline
\end{tabular}

As the effluent solution $\mathrm{pH}$ dropped, the $\mathrm{Pu}$ concentration increased. Figure 28 shows the relationship between the analyzed $\mathrm{pH}$ and Pu concentrations. The calculated concentration of the hydroxyl ions were plotted rather than the $\mathrm{pH}$ because the ion concentration is considered more related to the mechanism. The calculation used was for equilibrium concentration of $\mathrm{H}_{3} \mathrm{O}^{+}$and $\mathrm{OH}^{-}$in water at $25 \mathrm{EC}$. The similarity in the curve fits to the two data sets provides evidence that a similar mechanism occurred during both recirculation segments. The curve fit for the left leg of the second recirculation did not include the cluster of values to the left on the assumption that the Pu concentration had plateaued, and that including them would be incorrect.

One observation made from the curve is that there appears to be a knee in both sets of data. The location of the knee corresponds to the $\mathrm{pH}$ at which $\mathrm{HCO}_{3}{ }^{-}$changes to $\mathrm{CO}_{3}{ }^{-2}$, or vice versa. This supports an earlier conjecture that the concentration of carbonate in solution, in conjunction with the solution $\mathrm{pH}$, influences the concentration of $\mathrm{Pu}$ in solution. It was for this reason that the bicarbonate rinse was performed later in the test.

The data was compared to similar data generated during preparation of the sludge wash solutions. During preparation of the sludge wash solution, caustic was added to increase the $\mathrm{pH}$ and, therefore, reduce the $\mathrm{Pu}$ concentration. The comparison is shown in Figure 29. The different data sets are not similar, indicating that the bicarbonate effect could not be the only operable mechanism. This is not unreasonable since the effect here is dissolution from TIE-96 and the effect for the earlier data was from precipitation out of solution.

Except for changes related to decreasing $\mathrm{pH}$, the only effect of switching feed from sludge wash solution to recirculation solution should be flushing the sludge wash feed from the columns by the recirculation feed. Figures 30 and 31 illustrate -- to a large extent -- that this was the case. With the exception of hydroxyl and aluminum, the solutions were flushed from the columns in approximately $20 \mathrm{cv}$ during both recirculation segments. Table 21 illustrates the comparison of recirculation solution to the average recirculation effluent after $20 \mathrm{cv}$. The values in the table are normalized to the concentrations in the preceding sludge wash solutions. The effluent values are the average of all values, excluding those from the first $20 \mathrm{cv}$ after the feed solution switch. The agreement between the recirculation feed and effluent indicates the recirculation segment merely flushed all species but the hydroxyl and aluminum. ' 


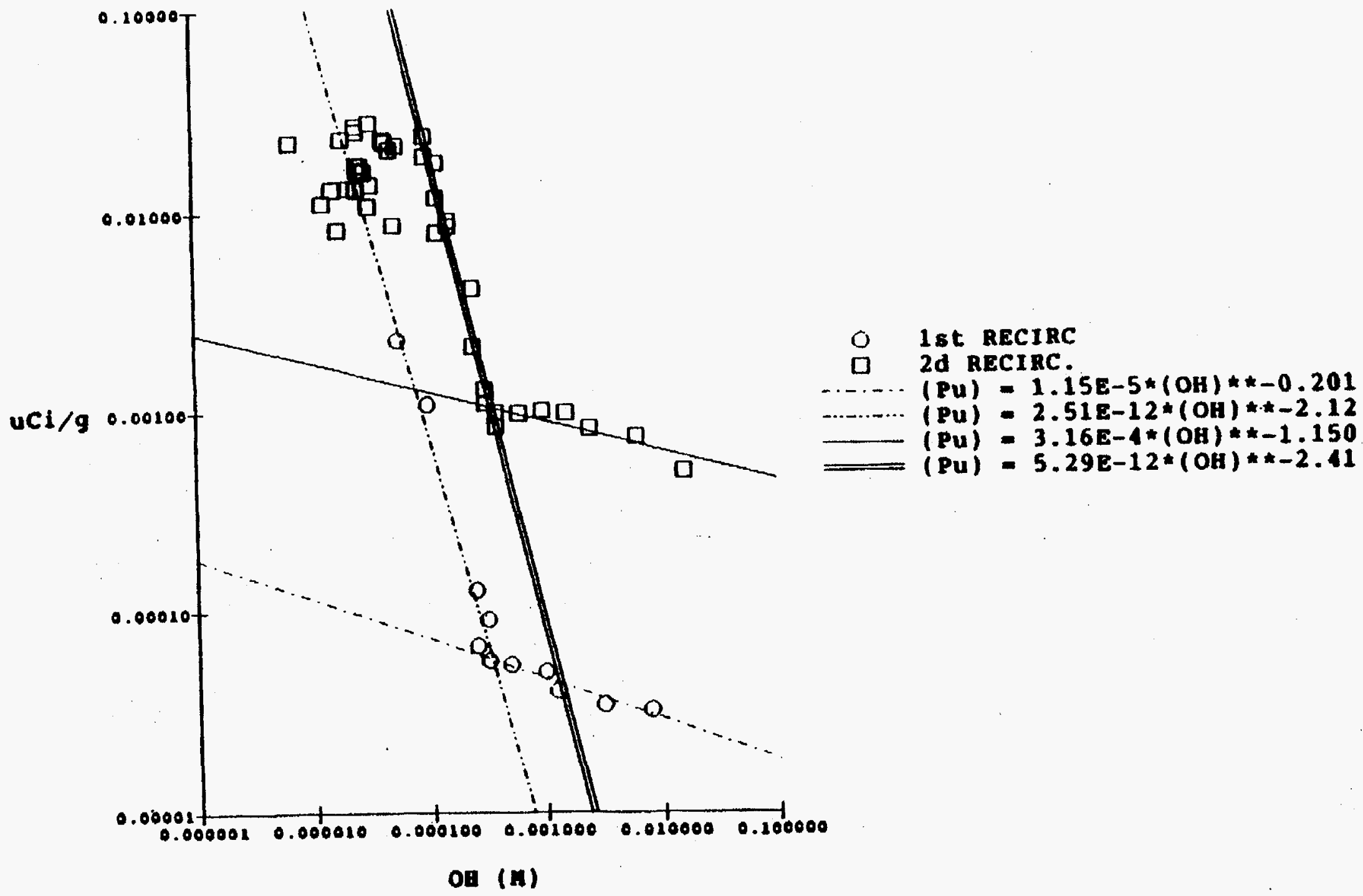




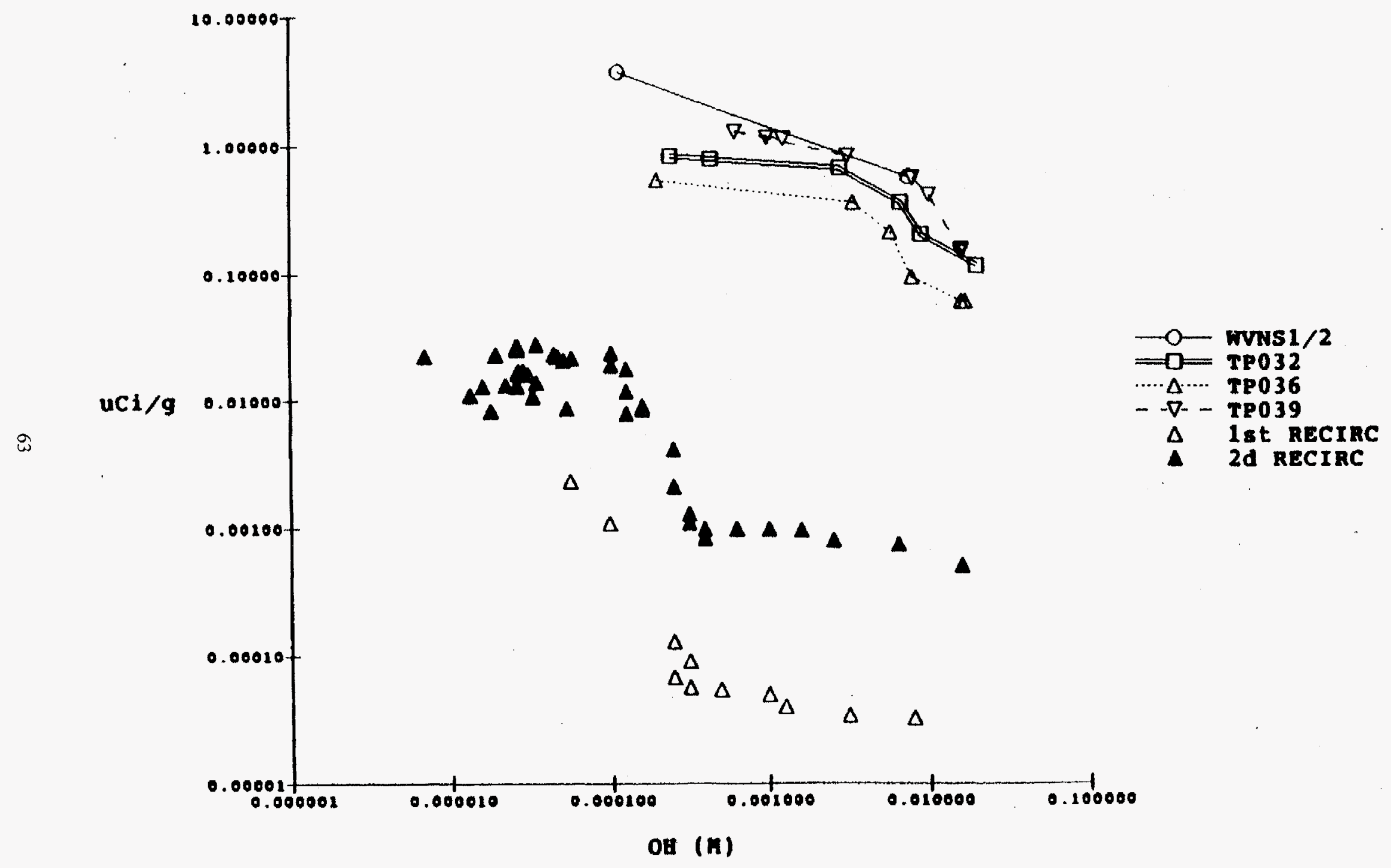

Figure 29. Pu/pH Relationship During Recirculation and Sludge Washing 


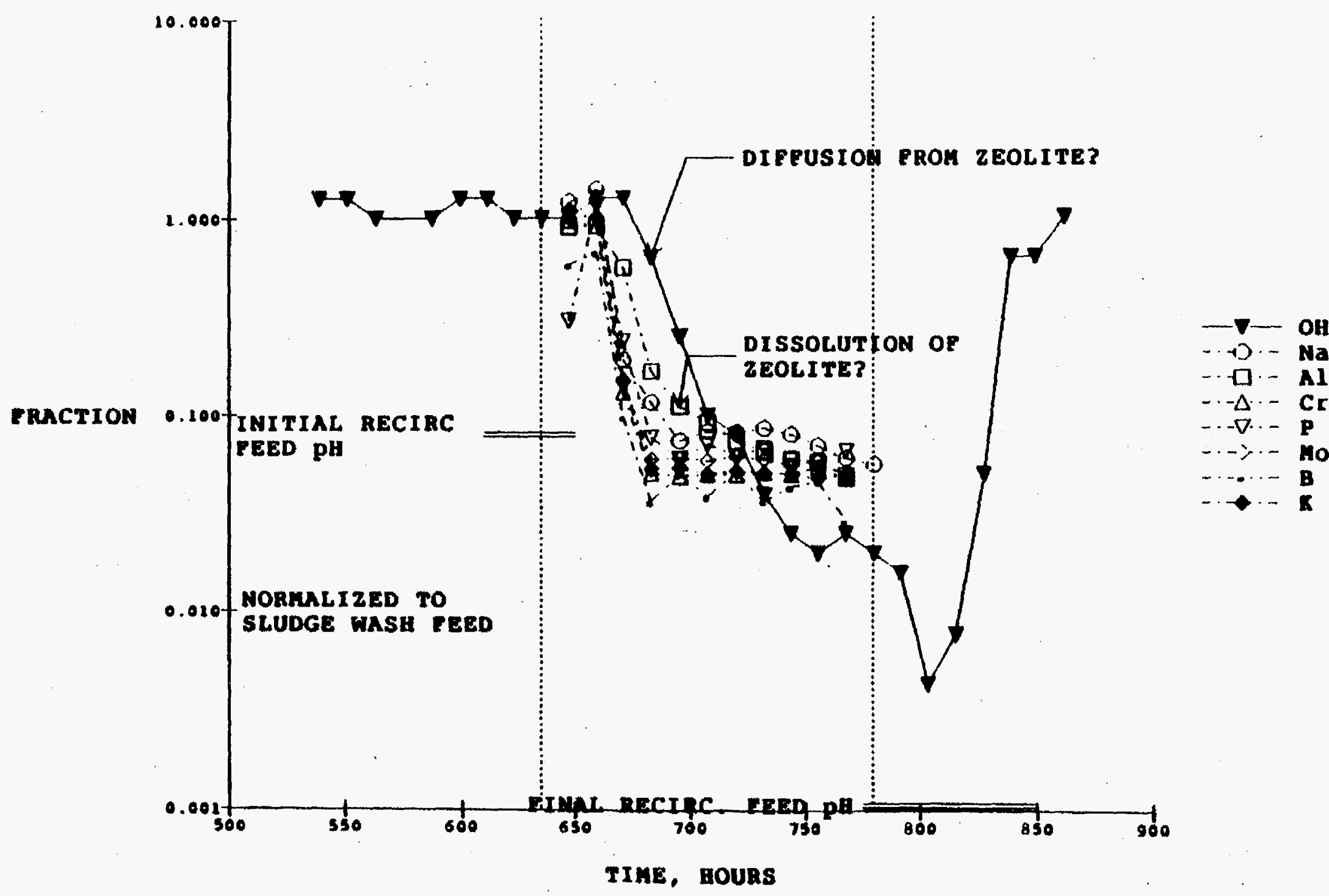




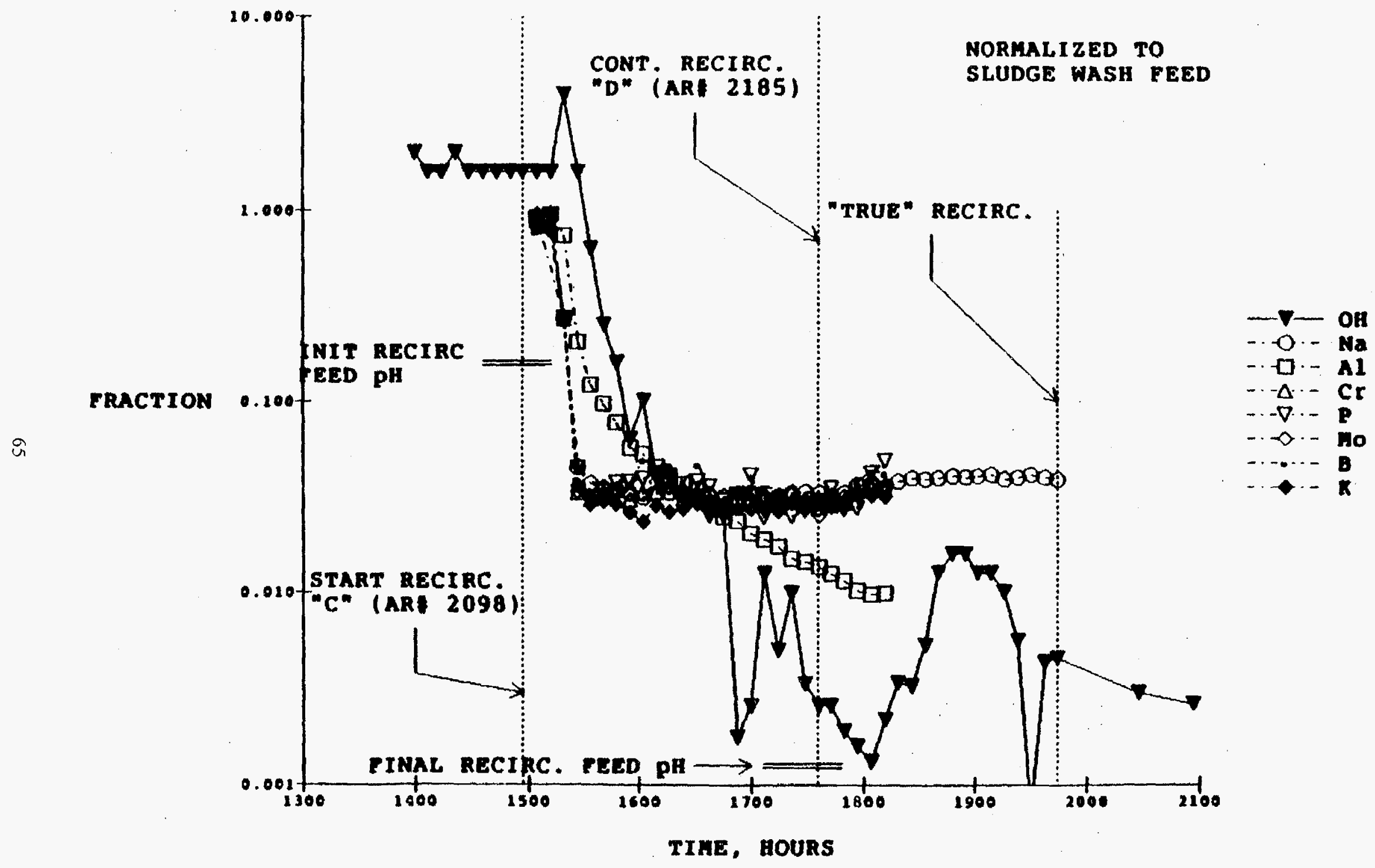

Figure 31. ICP and pH Data During Second Recirculation 
Table 21. WVNS TRQ/TP-042

Comparison of Recirculating Feed and Effluent Composition

(Normalized to Composition of Sludge Wash Feed Preceding Recirculation)

\begin{tabular}{|c|c|c|c|c|}
\hline Analysis & Recirc. \#1 Feed & Recirc. \#1 Effluent & Recirc. \#2 Feed & Recirc. \#2 Effluent \\
\hline $\mathrm{OH}^{-}$ & 0.079 & $\mathrm{n} / \mathrm{a}$ & 0.10 & $\mathrm{n} / \mathrm{a}$ \\
\hline $\mathrm{Al}$ & -- & $\mathrm{n} / \mathrm{a}$ & 0.037 & $\mathrm{n} / \mathrm{a}$ \\
\hline B & -- & 0.042 & 0.037 & 0.037 \\
\hline $\mathrm{Cr}$ & -- & 0.050 & 0.038 & 0.032 \\
\hline K & -- & 0.051 & 0.023 & 0.029 \\
\hline Mo & -- & 0.058 & 0.038 & 0.032 \\
\hline $\mathrm{Na}$ & 0.049 & 0.079 & 0.037 & 0.033 \\
\hline $\mathrm{P}$ & -- & 0.065 & 0.042 & 0.035 \\
\hline
\end{tabular}

The lag in flushing the hydroxyl ion might be explained by diffusion of the ion from the lattice. Even though the ion is not trapped by the lattice, it may have an affinity for the charge distribution in the lattice. The subsequent reduction in $\mathrm{OH}^{-}$concentration below the concentration of the recirculation solution feed was probably due to reduction in $\mathrm{pH}$ of the feed rather than reaction with the zeolite as observed by PNL. This is based on the similarity between the analysis of the recirculation solution feed after the test segment to the effluent $\mathrm{Pu}$ dissolved from the zeolite. An alternative explanation is that as the Pu dissolved from the zeolite, it complexes with several carbonate ions ( the number of carbonate ions per Pu ion should be between four and six, depending on the actual valence of the $\mathrm{Pu}$ ). This would lead to commensurate dissociation of bicarbonate to maintain the $\mathrm{CO}_{3}{ }^{-2} / \mathrm{HCO}_{3}{ }^{-}$equilibrium which, in turn, would release one $\mathrm{H}^{+}$ion per dissociating bicarbonate ion. This would also tend to reduce the hydroxyl concentration. The feed solution change should be the dominant effect.

The aluminum data is explained in conjunction with $\mathrm{pH}$. Figure 32 shows a consistent correlation between the aluminum and the hydroxyl for the two segments. Aluminum is not being dissolved from the lattice since the initial concentration for both recirculation segments was essentially the concentration of the corresponding sludge wash solutions. Dissolution should have resulted in effluent concentrations greater than the feed concentration. One of the mechanisms responsible is the following reaction.

$$
\mathrm{Al}(\mathrm{OH})_{3}(\mathrm{~s})->\mathrm{AlO}_{2}^{-}+\mathrm{H}^{+}+\mathrm{H}_{2} \mathrm{O}
$$

The $\mathrm{H}^{+}$is inversely proportional to the $\mathrm{OH}$. The approximate constant for this equation is $5 \mathrm{E}-13$. That is, aluminum concentration during recirculation was related to reversible reactions rather than to zeolite dissolution.

There was concern that the recirculation solution was removing significant quantities of Pu from the zeolite. Table 22 compares a Simpson's integration of the radionuclides retained on the zeolite prior to the first recirculation to a similar integration during the recirculation. The difference between the feed and effluent concentrations was used for these calculations. The Pu experienced the greatest dissolution at $0.2 \%$. This does not pose a problem for anticipated IRTS operations except for additional calculations required at the conclusion of a recirculation period. 


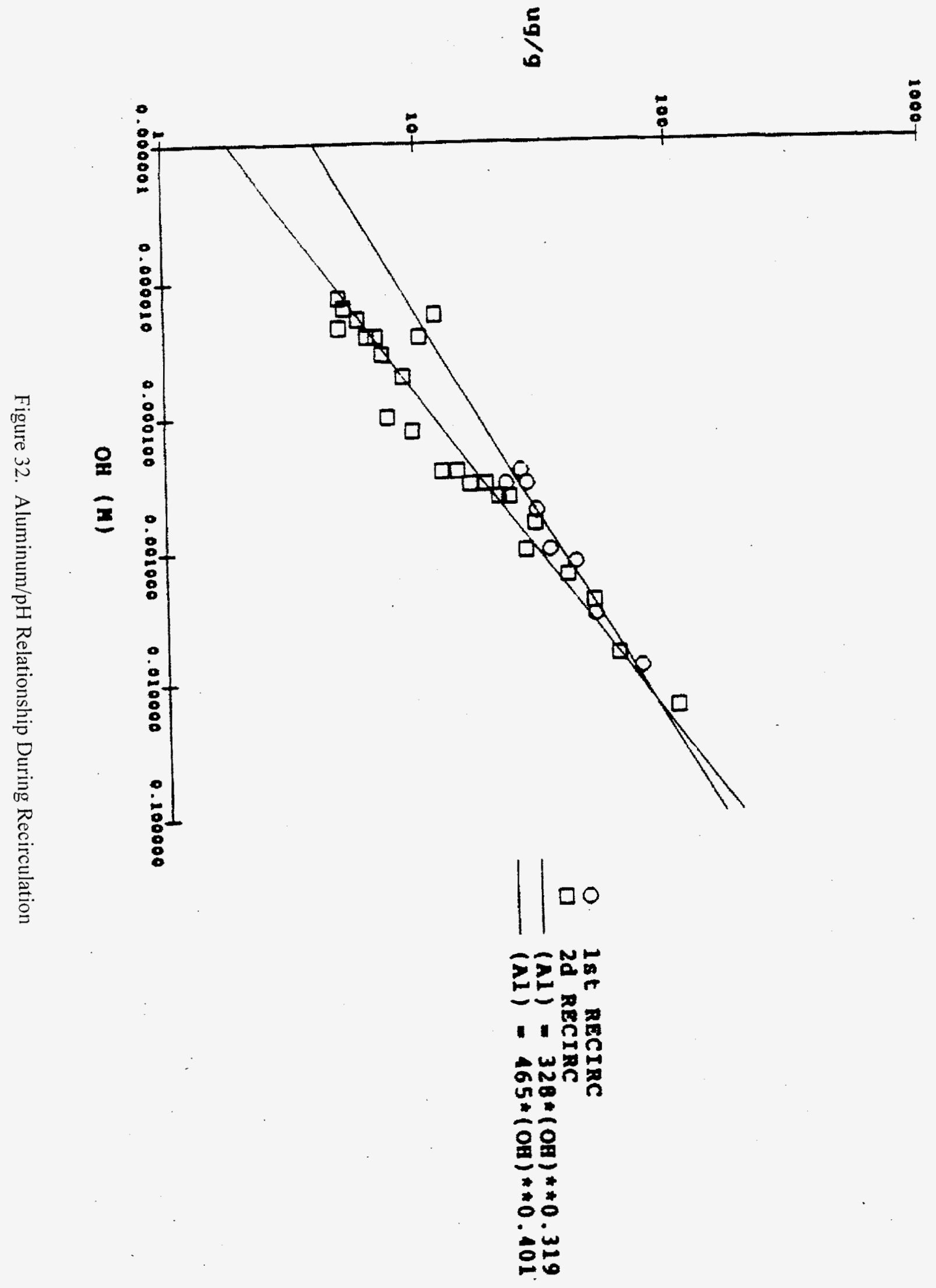


Table 22. WVNS TRQ/TP-042

Radionuclide Dissolution During First Recirculation

\begin{tabular}{lccc}
\hline Nuclide & $\begin{array}{c}\text { Retained on Zeolite } \\
\text { from Sludge Wash }\end{array}$ & $\begin{array}{c}\text { Dissolution from } \\
\text { Zeolite by Recirc. \#1 }\end{array}$ & $\begin{array}{c}\text { Percent } \\
\text { Removal }\end{array}$ \\
Cs-137 & $2.71 \mathrm{E} 5 \mu \mathrm{Ci}$ & $0.433 \mu \mathrm{Ci}$ & $1.6 \mathrm{E}-4$ \\
alpha-Pu & $12.8 \mu \mathrm{Ci}$ & $0.0199 \mu \mathrm{Ci}$ & 0.155 \\
$\mathrm{Sr}-90$ & $175 \mu \mathrm{Ci}$ & $9.24 \mathrm{E}-3 \mu \mathrm{Ci}$ & $5.28 \mathrm{E}-3$ \\
\hline
\end{tabular}

\subsubsection{True Recirculation}

The decreasing $\mathrm{pH}$ and increasing $\mathrm{Pu}$ concentration experienced during the first recirculation processed was the reason for performing the much longer second recirculation segment $(253 \mathrm{cv}$ vs. $83 \mathrm{cv})$. As seen in Figure 23 for $\mathrm{Pu}$ and Figure 30 for $\mathrm{pH}$ ( $\mathrm{pH}$ is displayed as the corresponding hydroxyl concentration value), the changes were accelerating rather than diminishing when sludge wash feed was resumed at the end of recirculation \#1. TP-042 was extended to allow the lengthy recirculation \#2 to determine if the changes would continue to accelerate. As seen in Figures 23 and 31, both the Pu concentration and the pH (hydroxyl) leveled off with the extended recirculation. Because of the importance of recirculation periods in STS operation, the test was again extended to allow testing "true recirculation." The concern was that changes in the effluent from the recirculation solution may result in further changes in the process even though the extended period of oncethrough recirculation showed a plateau. As seen by Figure 23, this was not the case. The "true recirculation" is seen to have less variability than either of the once-through recirculation segments. One difference between the "true recirculation" and the earlier recirculation segments was that the "true recirculation" experiment was sealed from the cell atmosphere. This avoided further $\mathrm{CO}_{2}$ absorption in the feed solution.

\subsubsection{Demineralized Water and Bicarbonate Rinses}

The last two recirculation segments of TP-042 were added to the test in an attempt to understand the mechanism responsible for dissolution of $\mathrm{Pu}$ observed in the preceding recirculation segments. There are no plans to implement either rinse in IRTS.

The demineralized water rinse of the TIE-96 should have been a true flush of the solution from the zeolite. Even though the $\mathrm{pH}$ during the demineralized water rinse was a stable 9.2, as compared to the 9.4 observed during true recirculation, the $\mathrm{Pu}$ concentration dropped monotonically to $3.6 \mathrm{E}-5 \mu \mathrm{Ci} / \mathrm{g}$ when the rinse stopped, compared to the stable average value of $1.6 \mathrm{E}-3 \mu \mathrm{Ci} / \mathrm{g}$ during true recirculation (see Figure 23 ). This is consistent with demineralized water flushing the Pu from the interstitial volume of the zeolite bed and indicates that $\mathrm{pH}$ alone is not responsible for the $\mathrm{Pu}$ dissolution during recirculation.

The sudden increase in Pu when the rinse was changed to a very dilute bicarbonate solution (see Table 18) indicated that the carbonate ion was probably needed to dissolve the $\mathrm{Pu}$. The $\mathrm{pH}$ during the bicarb. rinse was a stable 9.5. As discussed above (see Figure 29), carbonate is not the only mechanism for Pu solubility. This conclusion is based on the monotonic decrease in Pu concentration in the effluent with continued bicarb. rinse.

The jump in Cs-137 effluent concentration during the demineralized water rinse (see Figure 22) was possibly related to zeolite bed disturbances and resultant fines production as the two IE-96 columns were removed from the column line-up to permit the rinse of only the TIE-96 column. The Cs- 137 in the column effluent was not due to elution. This is known because previous tests at PNL with a demineralized water rinse of IE-96 did not 
result in Cs-137 elution. The increase in effluent Cs-137 concentration with the bicarbonate rinse was expected based on the sodium concentration in the rinse solution. No conclusions can be made regarding $\mathrm{Sr}-$ 90 dissolution during the last two rinses due to the random nature of data scatter as seen in Figure 24 .

\subsubsection{Application of TP-042 Results to IRTS Operation}

Cs-137 loading in the STS that is equivalent to the TP-042 data is shown in Figure 33. STS equivalent dimensional values (namely, curies and volume processed) were prepared by use of column volume as the scale factor from laboratory test data to STS conditions. The volume processed in the figure is on an undiluted, Tank 8D-2 basis. Volume flow through the columns would be double the Tank 8D-2 volume shown due to the planned 1:1 dilution of 8D-2 liquid with demineralized water. A column volume in STS was assumed to be 500 gallons (the volume currently in column C). The Cs- 137 capacity per campaign observed during TP-042 was significantly above the value assumed as a basis for TIE-96 procurement.

The Cs-137 processed in TP-042 during simulated campaign \#22 was more than double the average Cs- 137 per STS campaign. Three factors contributed to this: First, the lead column in TP- 042 at $\gg 2^{\circ} \mathrm{C}$ was significantly colder than IRTS operations. Second, the columns in the test were taken to greater breakthrough before change-out. Third, the columns in the test had not been partially loaded at the start of feeding. In reality, this last factor may not be too different from the start of campaign \#22 since column B, now loaded in the STS, ended campaign $\$ 21$ with $5.95 \mu \mathrm{Ci} / \mathrm{ml}$ feed and $0.32 \mu \mathrm{Ci} / \mathrm{ml}$ effluent.

A different perspective on the data relates to the ability to concentrate the effluent in the LWTS. Figures 34 , 35 , and 36 display the effluent $\mu \mathrm{Ci} / \mathrm{g}$-salt for $\mathrm{Cs}-137, \mathrm{Pu}$, and $\mathrm{Sr}-90$, respectively for the sludge wash feed and recirculation segments of the test. This data is useful in calculating the concentration of the radionuclides in the cement waste-form at various TDS concentration targets in the LWTS. Thus, if the allowable Pu value is $0.0135 \mu \mathrm{Ci}$-Pu.g-salt (a value corresponding to 25\% TDS in Tank 5D-15A), Figure 35 would indicate that each campaign should have a fresh TIE-96 column. This may require that only TIE-96 be charged to the STS columns during sludge wash operations. The data also has implications for disposition of the recirculation solutions at the conclusion of a recirculation period. A calculation must be made at the end of each STS recirculation period to decided whether the solution can be forwarded to the LWTS or must be returned to Tank 8D-2. 


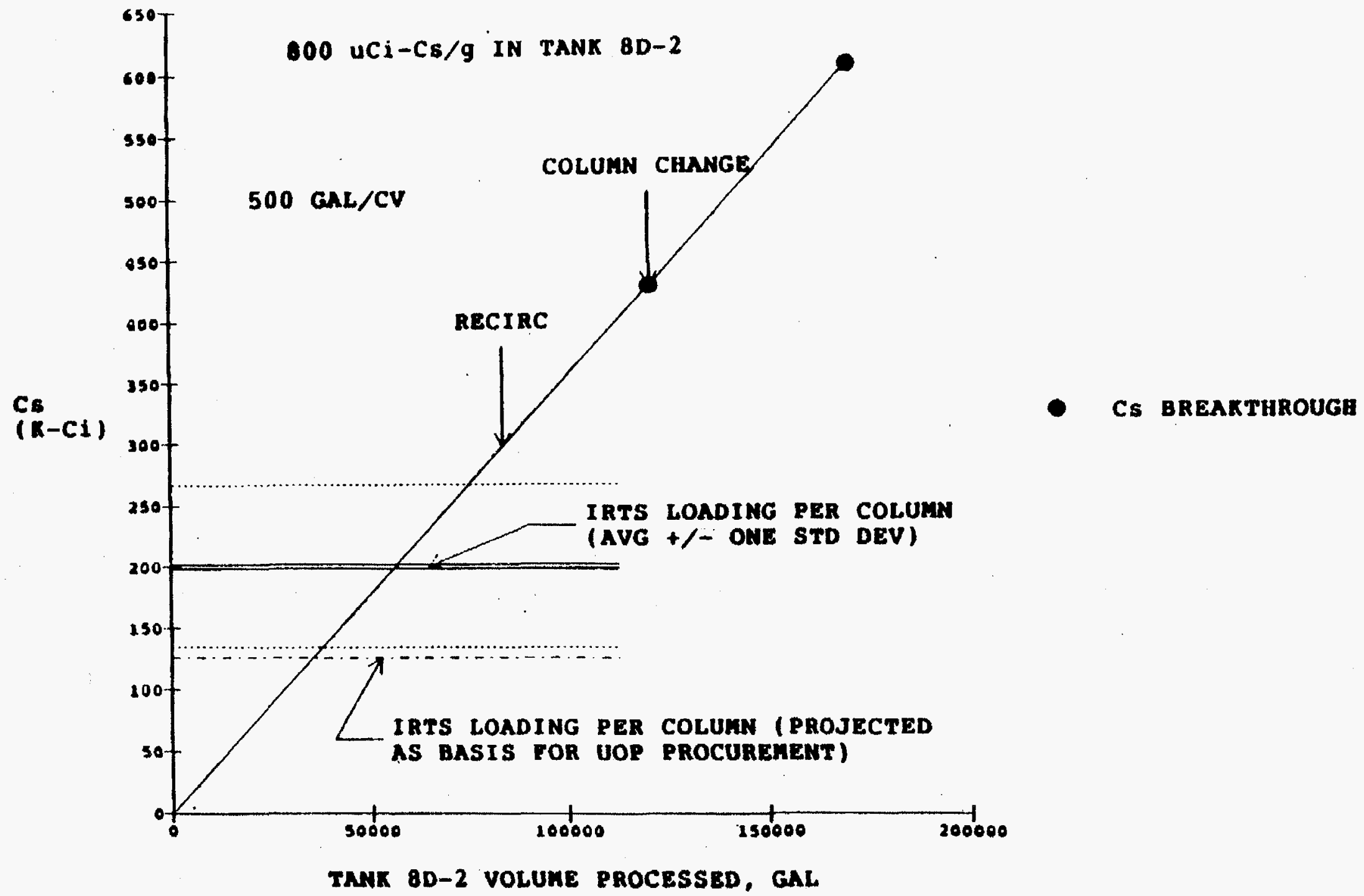

Figure 33. Cs-137 Processing STS Equivalent Basis 


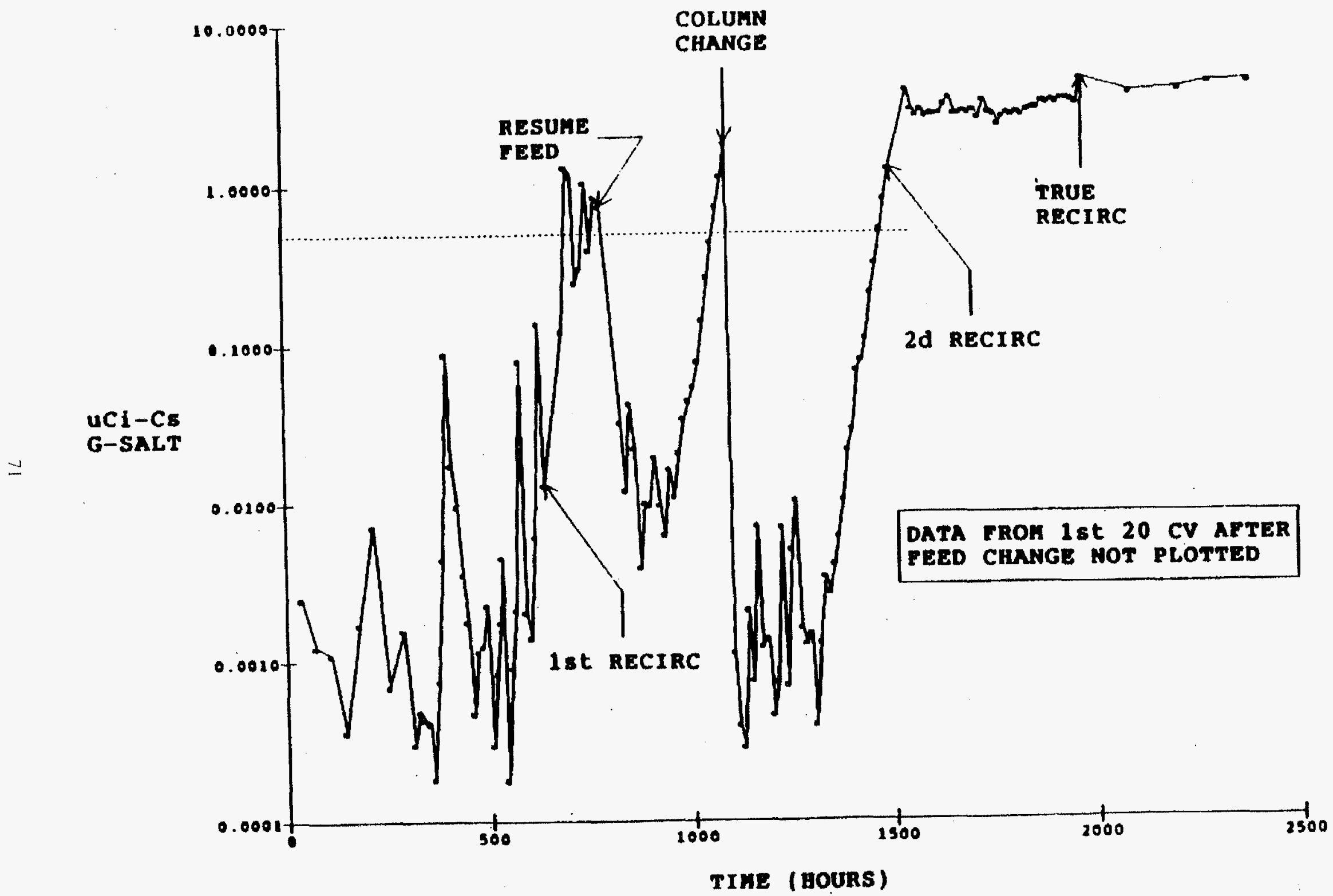

Figure 34. Cs-137 Data Related to CSS 


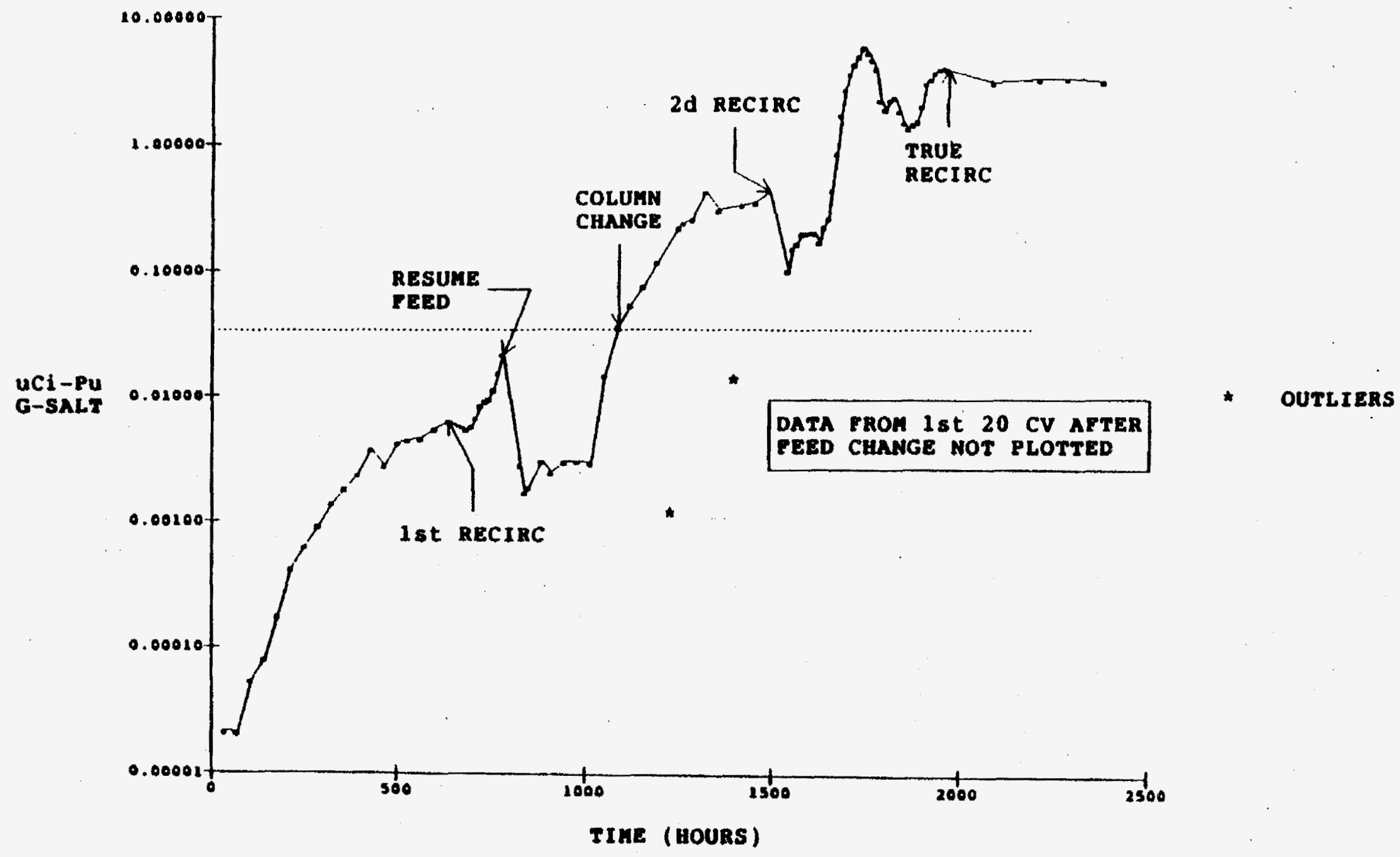




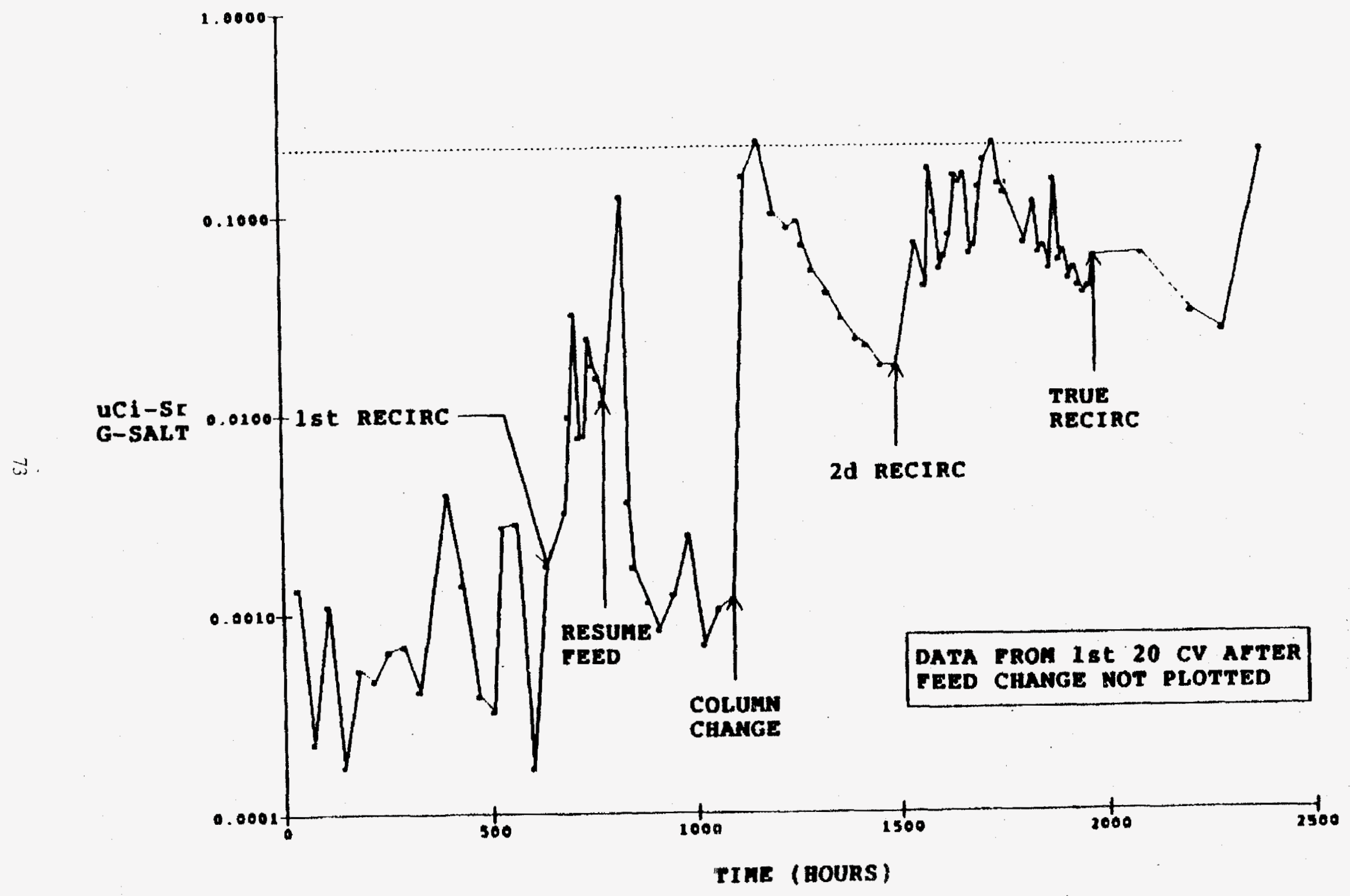

Figure 36. Sr-90 Data Related to CSS 


\subsection{Caustic Effects on Zeolite Stability}

Previous laboratory tests at PNL had showed that a reaction occurs between zeolite and the hydroxide ion associated with the Tank 8D-2 sludge wash solution. Scientists at PNL found that when $0.001 \mathrm{M} \mathrm{NaOH}$ was used in flow-through columns, there is an initial, rapid drop in $\mathrm{pH}$ to as low as 6.2 , followed by a slower rise in $\mathrm{pH}$ back up to 10.8 to 11.0 . This is also evidenced here at the WVDP where periodic additions of sodium hydroxide to Tank 8D-1 are required to maintain the $\mathrm{pH}$ at 11 . Tank $8 \mathrm{D}-1$ is storing the discharged IE-96 zeolite from previous STS operations. No previous tests had been performed to determine the effects of high caustic with a fixed quantity of zeolite and continuous feed of high-pH solutions over an extended period of time (»20 days) on the stability of the zeolite materials (both IE-96 and TIE-96).

This test was required to confirm the ability to expand or fluidize the beds of IE-96 and titanium-treated TIE-96 after processing of high-caustic waste solutions. ${ }^{13}$ The ability to fluidize the columns ensures that the columns can be either dumped or sluiced when necessary. Flow-through tests were conducted with nonradioactive, high-pH solutions for 400 column volumes at a $0.8 \mathrm{cv} / \mathrm{hr}$ flow rate.

All zeolite columns tests with radioactive solutions have shown that TIE-96 zeolite will remove Cs-137, Sr-90, and Pu from Tank 8D-2 sludge wash solutions. This test was required to address two additional concerns; the possibility of the ion-exchange bed plugging, and the stability of the zeolite above $\mathrm{pH} 11$. Aluminum in the Tank 8D-2 sludge may be dissolved by the excess caustic $(\mathrm{pH}>11.8)$ during sludge washing forming a soluble sodium aluminate compound. The dissolved aluminum may reprecipitate in the columns if the $\mathrm{pH}$ of the solution drops during the initial column loading. Chemical attack of the zeolite by the high- caustic solution may also provide a potential source of calcium or aluminum to provide ion-exchange column or post-filter plugging during column operation. In addition, physical changes in the zeolite during high- $\mathrm{pH}$ contact that might inhibit the columns from being dumped or sluiced when loaded were of vital concern.

The results from this test show that the high $\mathrm{pH}(\approx 12.5)$ anticipated to be used during the sludge wash operation and wash processing through the STS will not degrade the zeolite ion-exchanger or fuse it into a solid mass. An aluminum precipitation was observed to form during initial column operations as the $\mathrm{pH}$ of the solutions within the columns dropped to as low as $\mathrm{pH}$ 4.4. Most of the precipitate redissolved as the $\mathrm{pH}$ subsequently increased in the columns with continued flow of the simulated wash liquids.

\subsubsection{Test Parameters}

\subsubsection{Column-test Feed Solutions}

The test solution, a synthetic sludge wash ( $8-10 \mathrm{wt} \%$ solids), was prepared in concentrations of key species expected during Tank $8 \mathrm{D}-2$ sludge wash cycle 1 , with the $\mathrm{pH}$ adjusted to $12.5 \mathrm{using} \mathrm{NaOH}$. A summary of the synthetic wash solution constituents is provided in Tables 23 and 24. Three ion-exchange columns were used in series to determine the effect of a high-caustic sludge wash solution on both IE-96 and TIE-96 zeolites.

\subsubsection{2 pH Changes During Flow Tests}

Approximately 400 column volumes (cv) of feed at $40^{\circ} \mathrm{C}$ were passed through the columns. The volume processed is comparable to the flow that may be expected through an ion-exchange column in the STS during the life of the zeolite column charge. The aqueous effluent from each column was periodically sampled to determine changes in $\mathrm{pH}$ as a function of column volumes processed. 
Table 23. Synthetic Sludge Wash Solution Components, 10\% Salt Waste Makeup for High-pH Testing

\begin{tabular}{ll}
\hline Component & Gram/Liter \\
$\mathrm{NaNO}_{3}$ & 38.25 \\
$\mathrm{Na}_{2} \mathrm{SO}_{4}$ & 24.15 \\
$\mathrm{KNO}_{3}$ & 3.79 \\
$\mathrm{CrO}_{3}$ & 0.0016 \\
$\mathrm{NaCl}$ & 0.56 \\
$\mathrm{RbNO}_{3}$ & 0.014 \\
$\mathrm{Na}_{2} \mathrm{CO}_{3}$ & 3.18 \\
$\mathrm{NaHCO}_{3}$ & 5.29 \\
$\mathrm{NaNO}_{2}$ & 38.64 \\
$\mathrm{Na}_{2} \mathrm{HPO}_{4} \cong 7 \mathrm{H}_{2} \mathrm{O}$ & 0.046 \\
$\mathrm{CsNO}_{3}$ & 0.036 \\
$\mathrm{Al}\left(\mathrm{NO}_{3}\right)_{3} \cong 9 \mathrm{H}_{2} \mathrm{O}$ & 15 \\
$\mathrm{Ca}\left(\mathrm{NO}_{3}\right)_{2} \cong 4 \mathrm{H}_{2} \mathrm{O}$ & 0.071 \\
$\mathrm{NaOH}$ & 1.26 \\
$\mathrm{pH}$ & $\approx 12$ \\
\hline
\end{tabular}

\subsubsection{Column Expansion Tests}

To provide a measure of physical change in the zeolite and to determine if the zeolite would fuse or remain free-flowing, each column of zeolite was tested to determined bed expansion as a function of water flow (milliliters per minute) before and after exposure to the caustic feed solution.

\subsubsection{Ion-exchange Columns}

Three water-jacketed ion-exchange columns were connected in series and maintained at $40^{\circ} \mathrm{C}$ during the test. The glass columns that were used provided a zeolite bed height-to-diameter ratio of 8 , and a sufficient total column height ( 18 inches) to allow for bed expansion of at least two times the original height. Each of the first two columns were charged with $100 \mathrm{ml}$ of IE- 96 zeolite. The third column was charged with $100 \mathrm{ml}$ of TIE-96. 


\subsubsection{Zeolite Material}

The IE-96 zeolite used in this test was manufactured and sold to PNL by Union Carbide under PNL P.O. 7990, lot \# 939681090001, 20x40 mesh. The TIE-96 used in this test was made in UOP's pilot plant in response to the WVNS purchase order.

\begin{tabular}{ll}
\hline \multicolumn{2}{c}{$\begin{array}{l}\text { Table 24. Synthetic Sludge Wash Solution Species, } \\
10 \% \text { Salt Waste Makeup for High-pH Testing }\end{array}$} \\
\hline Species & Moles/Liter \\
$\mathrm{Na}$ & 1.51 \\
$\mathrm{Ca}$ & $3.0 \mathrm{E}-4$ \\
$\mathrm{Al}$ & 0.04 \\
$\mathrm{Cs}$ & $1.7 \mathrm{E}-4$ \\
$\mathrm{Cr}$ & $1.6 \mathrm{E}-5$ \\
$\mathrm{~K}$ & 0.038 \\
$\mathrm{Rb}$ & $9.3 \mathrm{E}-5$ \\
$\mathrm{Cl}$ & $9.5 \mathrm{E}-3$ \\
$\mathrm{PO}_{4}$ & $1.7 \mathrm{E}-4$ \\
$\mathrm{NO}_{3}$ & 0.45 \\
$\mathrm{NO}_{2}$ & 0.56 \\
$\mathrm{SO}_{4}$ & 0.17 \\
$\mathrm{OH}$ & 0.0316 \\
$\mathrm{CO}_{3}$ & 0.03 \\
$\mathrm{HCO}_{3}$ & 0.063 \\
\hline
\end{tabular}

\subsubsection{Ion-exchange Flow Tests}

\subsubsection{1 pH Changes}

During flow-testing through the three-column system, $\mathrm{pH}$ values were determined as a function of column volumes of effluent and compared with the feed value of $\mathrm{pH} 12.6$. During the first $15 \mathrm{cv}$, the first IE-96 column effluent increased from $\mathrm{pH} 10$ to 12.6. During the same period, the second IE-96 column effluent increased from $\mathrm{pH} 6.5$ to 12.6 . A white precipitate, approximately $3 / 16$-inch thick, formed on the top of the second IE-96 column after three column volumes of feed had passed through the first column. The precipitate formed at a $\mathrm{pH}$ of 6.7. The majority of the precipitate dissolved as the $\mathrm{pH}$ increased to 9.8. This is shown on Figure 37. The remaining white precipitate on the second IE-96 column was analyzed at the completion of the flow portion of the test and the result of the oxide analysis is provided in Table 25 . The majority of the material found was calcium phosphate which is not soluble in a high-caustic solution. From the third column, containing the TIE-96 column, the effluent increased from an initial $\mathrm{pH}$ of 4.6 to 12.6 over $25 \mathrm{cv}$. White solids formed within three hours, approximately $3 / 16$-inch thick, but completely redissolved as the effluent from the this column reached a $\mathrm{pH}$ of 9.6. This phenomenon is also noted in Figure 37. 


\section{pH Profile During 10\% Salt Loading - Water Presoak}

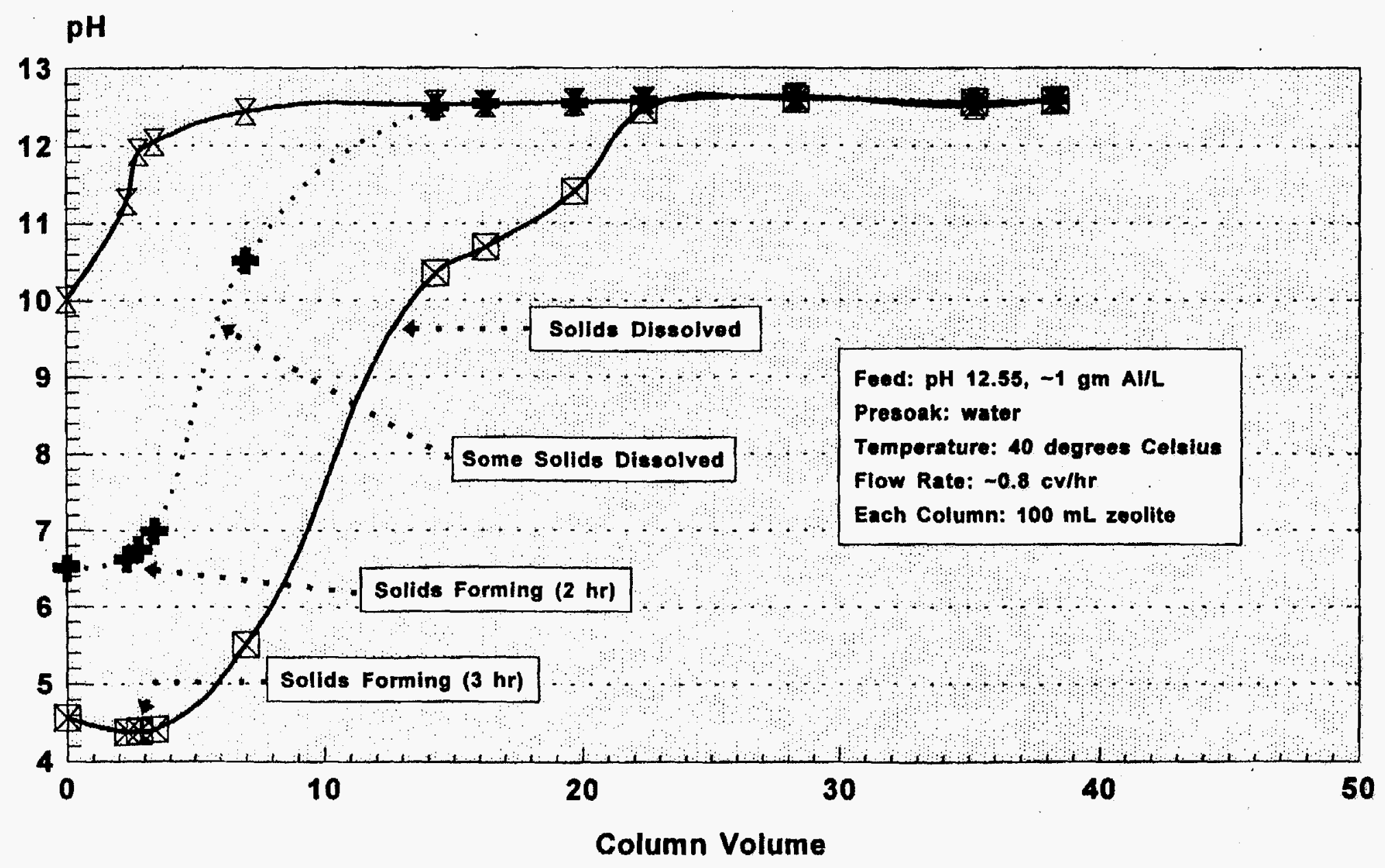

ZIE-96, column \#1 WIE-96, column \#2 ZTIE-96, Column \#3

Figure 37. pH Profile During 10\% Salt Waste Loading -- Water Presoak 


\subsubsection{Column Expansion Tests}

Bed expansion tests were performed before and after completion of the high $\mathrm{pH}$ feed test. No major differences were found between these bed expansion values as shown in Figure 38. No zeolite or titanium fines were noted in the water during the final bed expansion tests, indicating that the zeolite had not degraded.

\subsubsection{Sample Analysis}

Because the expansion tests had not shown degradation of the zeolite in the columns, none of the aqueous samples collected during the flow-through test were submitted for analysis. Samples of the "as received" and tested zeolites were analyzed to determine if there were differences determined by changes in the oxide weight percent. No significant changes were noted. There was a $1 \mathrm{wt} \%$ loss in the $\mathrm{TiO}_{2}$, dropping from $5.15 \mathrm{wt} \%$ to $4 \mathrm{wt} \%$; a decrease of $22 \%$ in the total $\mathrm{TiO}_{2}$. It is not apparent at this time if this was significant. The precipitate remaining on top of the second IE-96 column was analyzed and the results are provided in Table 25 . The major constituent appears to be calcium phosphate.

\begin{tabular}{ll}
\multicolumn{2}{c}{$\begin{array}{c}\text { Table 25. Analysis of White Precipitate -- } \\
\text { High-pH Ion-exchange Tests }\end{array}$} \\
\hline Oxide (wt.\%) & Found on Column \#2 \\
$\mathrm{Al}_{2} \mathrm{O}_{3}$ & 6.4 \\
$\mathrm{~B}_{2} \mathrm{O}_{3}$ & 3.93 \\
$\mathrm{BaO}$ & 0.152 \\
$\mathrm{CaO}$ & 39.9 \\
$\mathrm{Fe}_{2} \mathrm{O}_{3}$ & 0.298 \\
$\mathrm{MgO}$ & 1.3 \\
$\mathrm{MnO}_{2}$ & 0.009 \\
$\mathrm{Na}_{2} \mathrm{O}$ & 10.6 \\
$\mathrm{P}_{2} \mathrm{O}_{5}$ & 16.0 \\
$\mathrm{PbO}$ & 0.04 \\
$\mathrm{SiO}_{2}$ & 9.80 \\
$\mathrm{SrO}$ & 0.33 \\
$\mathrm{TiO}_{2}$ & 0.016 \\
$\mathrm{~V}_{2} \mathrm{O}_{3}$ & -- \\
$\mathrm{ZnO}$ & 0.04 \\
\hline
\end{tabular}

$\mathrm{KOH}$ used to fuse sample for analysis in a zirconium crucible. 


\section{Zeolite Bed Expansion as a Function of Water Flow}
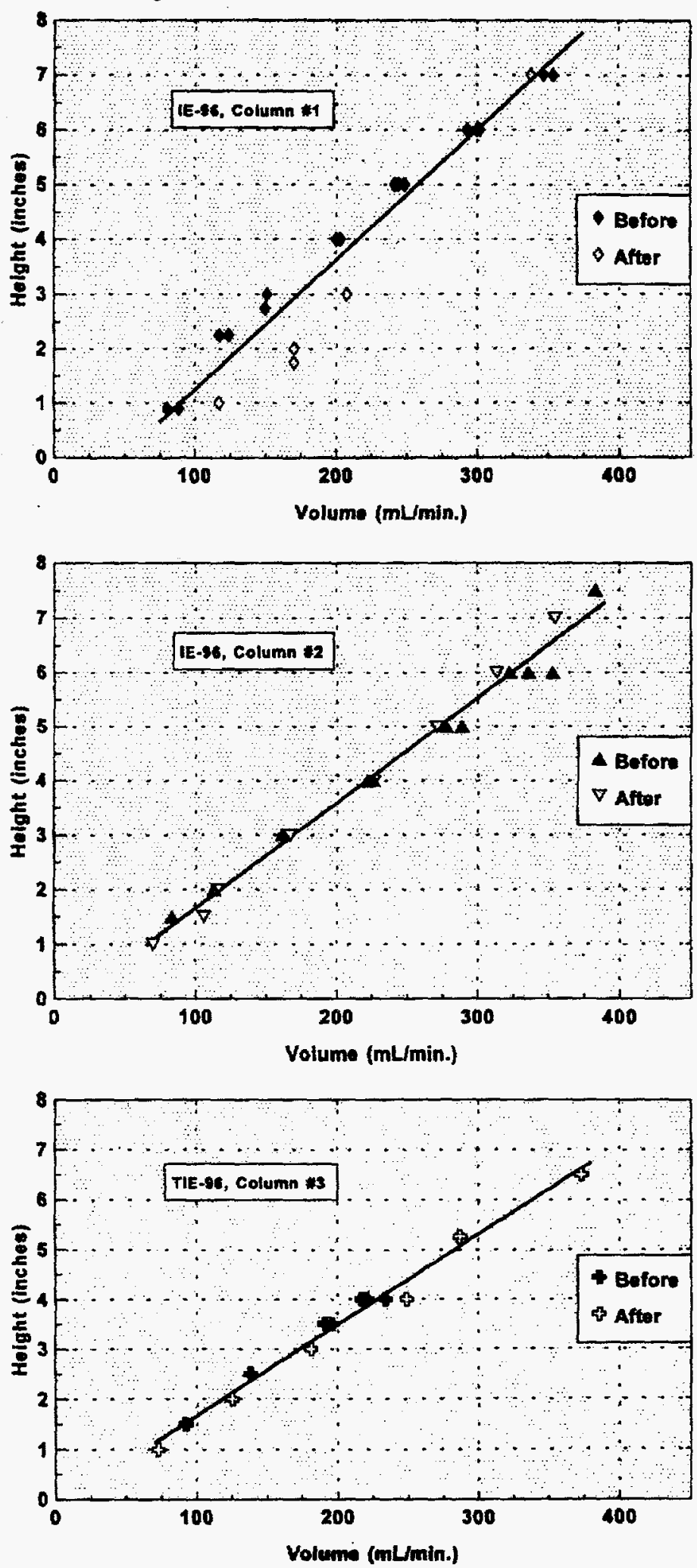

Figure 38. Zeolite Bed Expansion as a Function of Water Flow 


\subsubsection{Discussion of Results}

High $\mathrm{pH}$ solutions (pH 12.5), at levels anticipated during Tank 8D-2 sludge wash solution processing will not degrade or fuse IE-96 and TIE-96 zeolite. This test was completed under the most adverse conditions possible, i.e., $\mathrm{pH}>12.5$, aluminum concentration of $1 \mathrm{~g} /$ liter, column temperature of $40^{\circ} \mathrm{C}$, and fresh zeolite material. This test was initiated to quantify the effect of the sludge wash solution adjusted to a pH of 12.5 on the chemical stability of the zeolite and to ensure that the zeolite will remain free-flowing and not compromise subsequent discharge from STS columns after loading. Approximately 400 column volumes of high caustic feed were passed through a series of three ion-exchange columns during the 20-day test. Bed expansion before and after the test, and chemical analysis of the exchanger were used to determine that no major physical changes had resulted from the exposure to the high-caustic solution. Aluminum precipitation was observed in the second and third ion-exchange columns and in the final column effluent during the initial phase of the high-caustic feed test. The precipitation occurred when the $\mathrm{pH}$ values were 10 for the first (IE-96) column effluent, 6.5 for the second (IE-96) column effluent, and 4.4 for the third column (TIE-96) effluent. The solids on the TIE-96 column and in the effluent were completely redissolved as the $\mathrm{pH}$ of the effluent returned to 12.6.

\subsection{Caustic Effects on Ion-exchange IONSIV IE-96 and TIE-96 Zeolite}

Extensive PNL Laboratory column tests have been performed with a fixed quantity of zeolite and continuous feed of high-pH solutions. ${ }^{13}$ High $\mathrm{pH}$ solutions ( $\mathrm{pH} 12.5$ ), at levels above those previously considered for sludge wash processing, did not degrade or fuse the zeolite ion-exchanger IE-96 and TIE-96. Aluminum precipitation was observed in the laboratory ion-exchange columns and in the final effluent. This test was completed under the most adverse conditions expected, i.e., $\mathrm{pH}>12.5$, aluminum concentration of $1 \mathrm{~g} /$ liter, column temperature of $40^{\circ} \mathrm{C}$, and fresh zeolite material.

After completion of the above testing, additional nonradioactive laboratory tests were recommended using a lower $\mathrm{pH}$ feed of 12 , lower temperature more typical of plant operations $\left(12^{\circ} \mathrm{C}\right)$, and zeolite ion-exchanger IE-96 in columns one and two that had been partially loaded with Cs-137 through a pretreatment. ${ }^{14}$

The objective of this test was to further evaluate and determine if high-pH solutions, at levels anticipated during Tank 8D-2 sludge wash processing, will cause precipitates to form in the IE-96 and TIE-96 zeolite columns of the STS. It was intended that this test would simulate the start-up conditions anticipated during the resumption of STS operations processing sludge wash.

Column plugging was a concern arising from the aluminum in the sludge that will dissolve as $\mathrm{NaAlO}_{2}$ by the excess caustic $(\mathrm{pH}>11.8)$ during sludge washing forming a soluble sodium aluminate. This dissolved aluminum may reprecipitate as $\mathrm{Al}(\mathrm{OH})_{3}$ in the columns if the $\mathrm{pH}$ of the solution drops during the initial column loading. No aluminum hydroxide precipitation was observed in the ion-exchange columns. However, samples of the $10 \%$ salt waste effluent contained solids at aqueous $\mathrm{pH}$ values of 10.5 to 11 . This precipitation should not provide a source for column plugging during plant operation. It appears that the initial drop in $\mathrm{pH}$ and subsequent delay in reaching $\mathrm{pH}$ equilibrium in the TIE-96 column effluent was due to excess hydrogen ion in the zeolite structure resulting from the manufacturing process for TIE-96. The results from this test

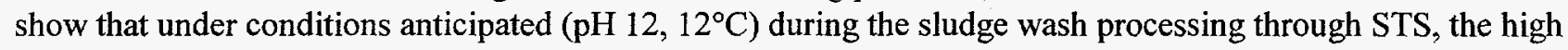
$\mathrm{pH}$ of the solution will not degrade IE-96 nor TIE-96 zeolite. 


\subsubsection{Column-test Feed Solutions}

Four separate feed solutions were used in this test. Each feed was used for a specific column flow test segment. The synthetic alkaline solution was prepared from diluting a portion of synthetic alkaline waste (nominal $6 \mathrm{M} \mathrm{Na}^{+}, \mathrm{pH}$ 10) 1:3 with water. This solution was used to equilibrate the two IE-96 columns and partially load them with Cs-137. The equilibrium was determined to have occurred once the $\mathrm{pH}$ of the columns' effluents and feed solution were equal.

\subsubsection{Diluted Alkaline Supernatant}

This solution $\left(1.5 \mathrm{~g} \mathrm{Na}^{+} / \mathrm{L}\right)$ was prepared by diluting $100 \mathrm{ml}$ of the above synthetic alkaline supernatant effluent to 3.11 liters with distilled water. This solution was used as the "recycle" wash solution used to equilibrate the IE-96 and TIE-96 columns in series.

\subsubsection{Synthetic Sludge Wash Waste}

The test solution, a synthetic sludge wash ( $8-10 \mathrm{wt} \%$ solids), was prepared in concentrations of key species expected during Tank 8D-2 sludge wash cycle 1 with the $\mathrm{pH}$ adjusted to 12 with $\mathrm{NaOH}$. A summary of the synthetic wash solution constituents is provided in Tables 23 and 24.

\subsubsection{3 $10 \%$ Salt Waste Recycle}

A diluted $10 \%$ salt waste recycle solution $\left(1.5 \mathrm{~g} \mathrm{Na}^{+} / \mathrm{L}\right)$ was prepared by diluting $864 \mathrm{ml}$ of the synthetic sludge wash effluent to 20 liters with distilled water. This solution was used to wash the three-column series until the effluent $\mathrm{pH}$ of all three columns are equivalent.

\subsection{2 lon-exchange Columns}

Three water-jacketed, ion-exchange columns were connected in series and maintained at $12^{\circ} \mathrm{C}$ during the test. The glass columns that were used provided a bed-to-diameter ratio of 8 . Each of the first two columns were charged with $100 \mathrm{ml}$ of the IE-96 zeolite. The third column was charged with $100 \mathrm{ml}$ of TIE-96.

\subsubsection{Zeolite Material}

The IE-96 zeolite used in this test was manufactured and sold to PNL by Union Carbide, under PNL P.O. 7990 , lot \# 939681090001, 20x40 mesh. The TIE-96 used in this test was made in UOP's manufacturing plant in response to the WVNS purchase order. A 50/50 mixture of TIE-96 was used in this test and was prepared from samples from drum 1 of lot 9757-3Z-91-000007 and drum 4 of lot 9757-3Z-91-000010; both drums of zeolite having been produced in small, production-scale equipment. 


\subsection{4 lon-exchange Flow Test}

\subsubsection{1 pH Changes During Flow Tests}

Both two and three ion-exchange column tests were used in series to quantify the effect of high-caustic sludge wash solution on zeolite. The aqueous effluent from each column was periodically sampled to determine changes in $\mathrm{pH}$ as a function of column volumes processed.

\subsubsection{Ion-exchange Flow Tests - - Equilibration of the IE-96 Columns}

The alkaline supernatant ( $\mathrm{pH} \mathrm{10)}$ was passed through the two IE-96 columns at $12^{\circ} \mathrm{C}$ and $0.8 \mathrm{cv} / \mathrm{hr}$. The pH was determined as a function of column volumes (cv) processed. The effluent was sampled every hour during the first 8 hours. This was continued until the $\mathrm{pH}$ of the effluent and feed were equivalent.

\subsubsection{Conditioning of IE-96 and TIE 96 and Flow-testing with Sludge Wash}

A diluted alkaline supernatant solution $\left(1.5 \mathrm{~g} \mathrm{Na}^{+} / \mathrm{L}\right)$ was used to equilibrate all three columns in series. This step was continued until the $\mathrm{pH}$ of the effluent and feed were equivalent. A synthetic sludge wash solution (8$10 \mathrm{wt} \%$ solids, $\mathrm{pH}$ 12) was passed through the three-column series at $12^{\circ} \mathrm{C}$ and $0.8 \mathrm{cv} / \mathrm{hr}$ until the effluent and feed $\mathrm{pH}$ were equivalent. $\mathrm{pH}$ changes in the zeolite were determined as a function of column volumes (cv) processed.

\subsubsection{Wash with $10 \%$ Salt Solution}

The three columns were washed by processing a diluted $10 \%$ salt waste recycle solution $\left(1.5 \mathrm{~g} \mathrm{Na}^{+} / \mathrm{L}\right)$ until the influent and effluent $\mathrm{pH}$ were equivalent. The recycle solution was prepared by dilution of the above flow-test column effluent.

\subsubsection{Discussion of Results}

Additional laboratory studies were completed to determine the effect of high-caustic sludge wash cycle 1 (pH $12,12^{\circ} \mathrm{C}$ ) on IE-96 and TIE-96 zeolite. This test was an attempt to simulate the start-up conditions in the STS for the processing of sludge wash cycle 1 since the STS presently has two partially Cs-137-loaded IE-96 columns remaining from the last processing campaign of alkaline supernatant at a $\mathrm{pH}$ of 10.

\subsubsection{Equilibration of the IE-96 Columns}

During the equilibration of the two IE-96 columns with alkaline supernatant (diluted 1:3, pH 10), the solution first displaced the water in the columns and a $\mathrm{pH}^{\circ} 10$ was achieved within $10 \mathrm{cv}$ (Figure 39a). After the equilibrium was achieved, the third column containing the TIE-96 was connected in series. 

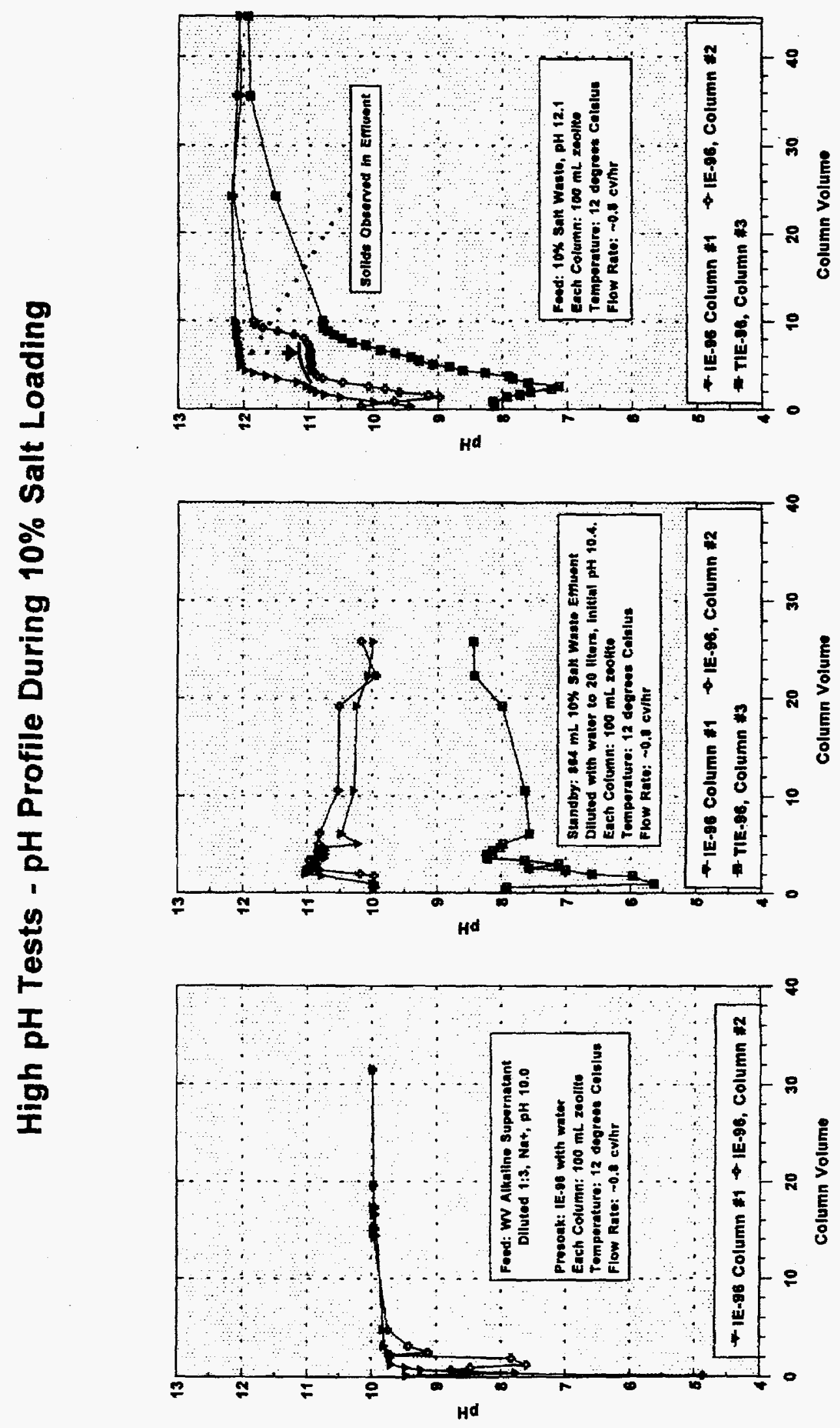


\subsubsection{Conditioning of IE-96 and TIE-96}

The three columns were then treated as if they were in a standby mode, with a dilute $\left(1.5 \mathrm{~g} \mathrm{Na}^{+} / \mathrm{L}\right)$ alkaline solution, $\mathrm{pH}$ 10.2. The objective of this step was to remove the alkaline supernatant feed from the first two columns and to equilibrate the third (TIE-96) column prior to $10 \%$ salt waste solution processing. The initial effluent $\mathrm{pH}$ values from the IE-96 columns \#1 and \#2 increased from 10 to a $\mathrm{pH}$ of 11 and, after $26 \mathrm{cv}$, again dropped to a $\mathrm{pH}$ of 10 (Figure $39 \mathrm{~b}$ ). In the same time frame, the effluent from the TIE-96 column was initially at a $\mathrm{pH}$ of 5.7 and increased in $\mathrm{pH}$ value to 8.5 after processing $26 \mathrm{cv}$ of wash solution. The original objective to equilibrate the TIE-96 column to a $\mathrm{pH}$ of 10 was not achieved.

\subsubsection{Flow-testing with Synthetic Sludge Wash}

After pretreating the IE-96 columns with alkaline supernatant and washing all three columns with dilute waste effluent, a $10 \%$ salt waste ( $\mathrm{pH} 12$ ) was fed to the three-column series. The first IE-96 column increased in $\mathrm{pH}$ value to 12 within $4 \mathrm{cv}$. The second IE-96 column, after an initial drop, increased to a pH of 11 after $5 \mathrm{cv}$ and plateaued, then increased to $>12$ after $11 \mathrm{cv}$. The TIE-96 column dropped initially to a pH of 7 and then slowly increased to a pH of 11.9 after $35 \mathrm{cv}$, (Figure 39c). Although no observable precipitate formed on the columns, precipitate was found in the TIE-96 column effluent samples between $\mathrm{pH}$ values of 10.5 and 11 . This indicates that precipitation may also be occurring within the zeolite structure. Solids were also found in the composited salt waste effluent until the $\mathrm{pH}$ in the composite exceeded $\mathrm{pH} \approx 12$ (reached after $40 \mathrm{cv}$ ).

\subsubsection{Wash with $10 \%$ Salt Solution}

A final wash of the three columns was initiated using a dilution of the $10 \%$ salt waste effluent to a value of $1.5 \mathrm{~g} \mathrm{Na}^{+} / \mathrm{L}$ (Figure 40). The initial $\mathrm{pH}$ of the wash solution was 10.4. The $\mathrm{pH}$ values in the wash effluent from the three columns dropped very slowly from above 12 to $10-10.5$ after $140 \mathrm{cv}$. The $\mathrm{pH}$ order was reverse of that shown in Figure 39c. During this exhaustive wash, it was also observed that the initial pH (10.4) of the stock wash solution ( 20 liters) dropped to a $\mathrm{pH}$ of 10.1 (indicating that carbonate reacting with the air was changing the $\mathrm{pH}$ value with time).

\subsubsection{Drop in Effluent pH}

One question that arose from the previous test on the caustic effect on zeolite is: what is the mechanism responsible for attaining $\mathrm{pH}$ values in the effluent below 7 . The $\mathrm{pH}$ drop below 7 was indicated when the wash step was initiated, as well as in several earlier caustic zeolite tests (Figure 39b). The mechanism for this observation has been postulated to arise from the proprietary titanium-treatment process used to load the titanium on the IE-96 zeolite. A caustic demand test, developed by PNL, shows that as compared to IE-96, various batches of TIE-96 produced by UOP have varying levels of acidity (Figure 41). The $\mathrm{H}^{+}$ions remaining in the TIE-96 structure provide the mechanism for lowering the $\mathrm{pH}$ of the solution. During initial alkaline waste processing through TIE-96, ions such as $\mathrm{Na}^{+}\left(\mathrm{NO}_{3}\right)$ are exchanging $\left(\mathrm{Na}^{+}\right)$back into the zeolite structure from solution, replacing the $\mathrm{H}^{+}$in the zeolite. The cations drive the $\mathrm{H}^{+}$into solution providing a very slight excess of acid, which exceeds the amount of available $\mathrm{OH}^{-}$ion in the initial effluent solution, thus accounting for the $\mathrm{pH}$ values below 7 . 


\section{pH Profile During Final Recycle Wash}

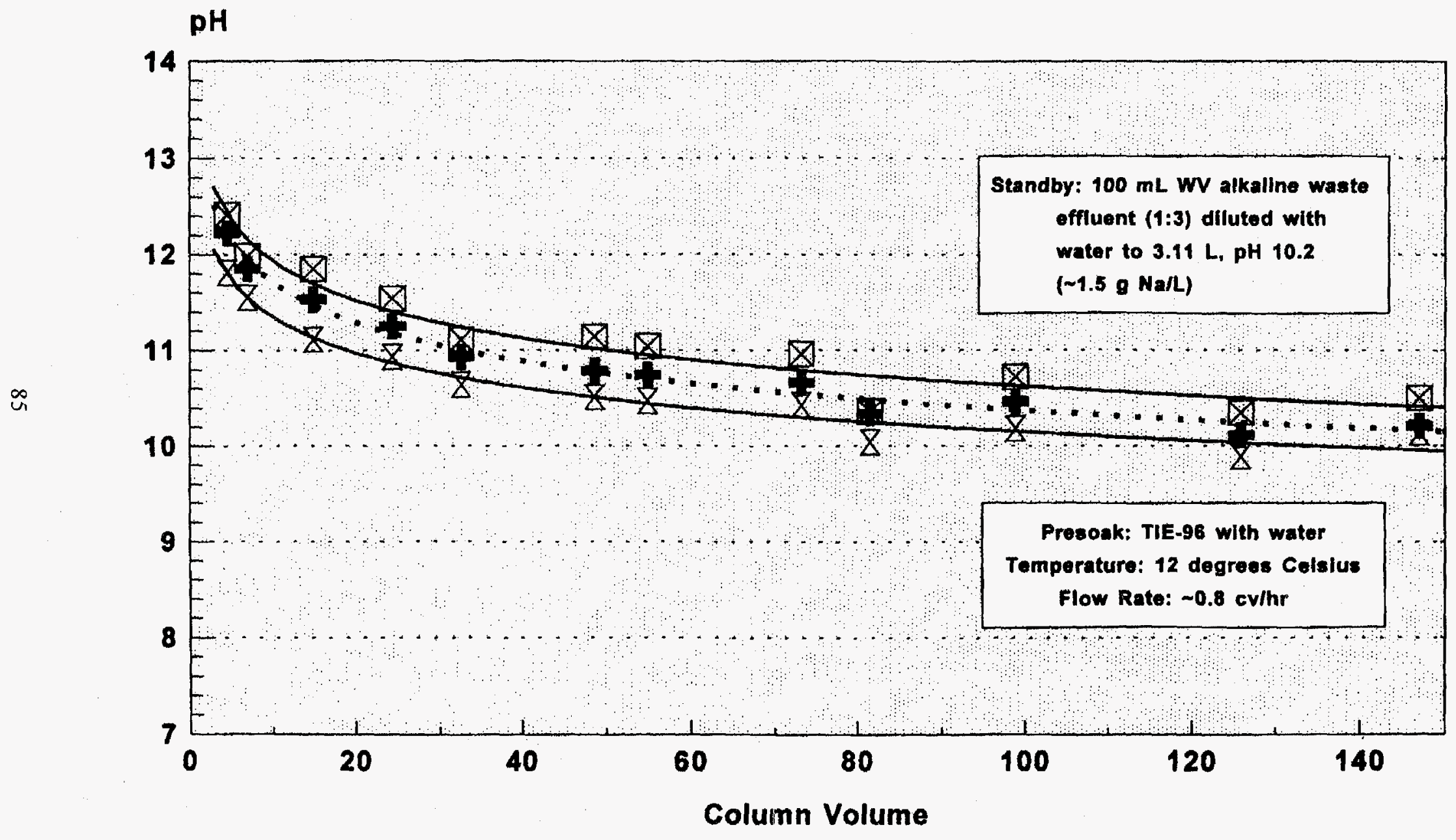

ZIE-96, Column \#1 \$IE-96, Column \#2 TTE-96, Column *3

Figure 40. pH Profile During Final Recycle Wash 


\section{Caustic Demand Test}

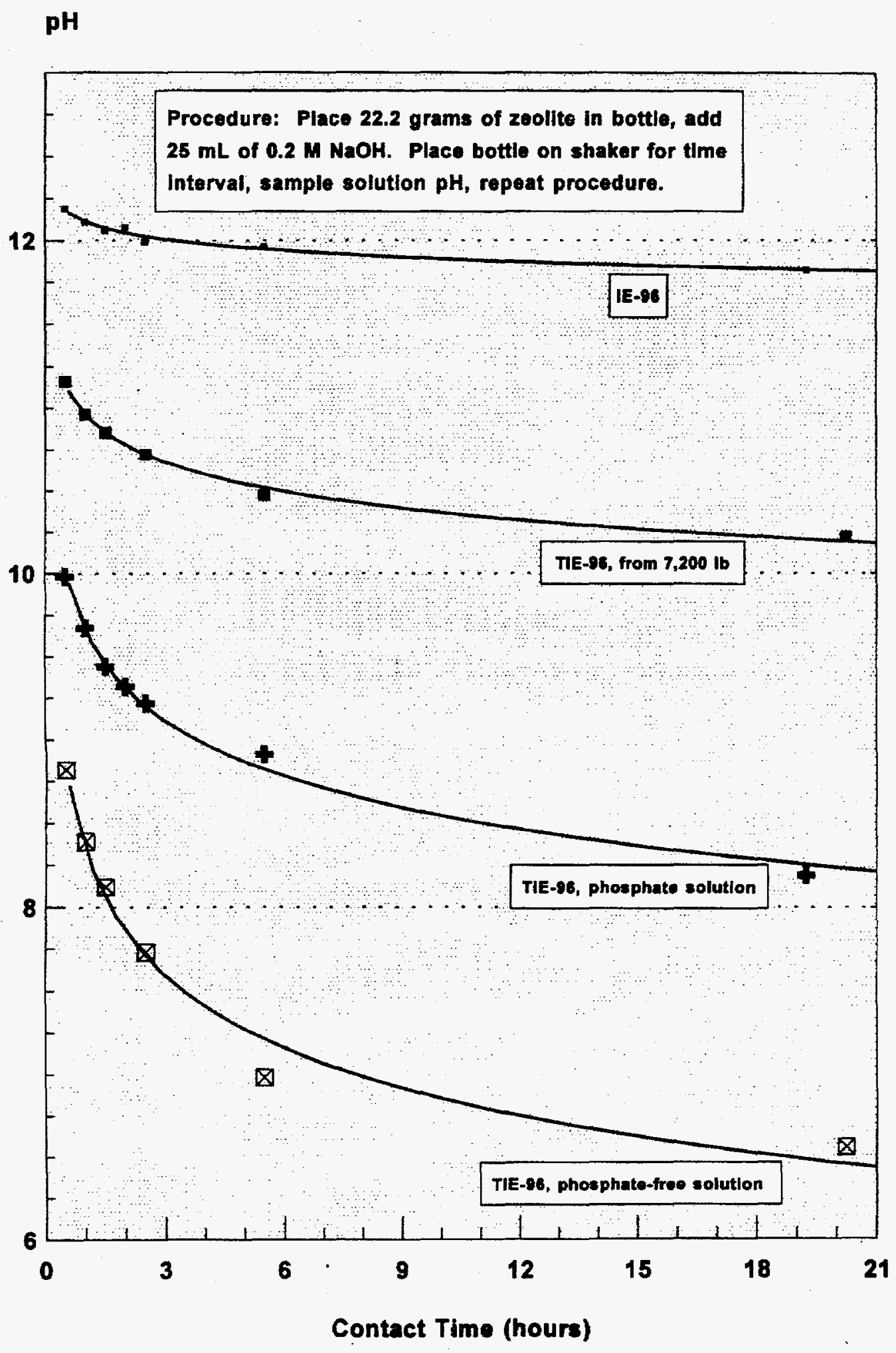

Figure 41. Caustic Demand Test 


\subsection{WVNS-TRQ-071 Zeolite Treatment of THOREX Sludge Wash Solution}

The purpose of this test was to verify effective $\mathrm{Cs}-137, \mathrm{Pu}$, and $\mathrm{Sr}-90$ removal from zeolite ion-exchange columns in series that reflected the anticipated operating mode of the STS during THOREX wash processing. ${ }^{15}$ The test simulated STS operations in the following aspects:

- The three-column series consisted of a lead TIE-96 column, followed by a IE-96 column, with a TIE96 column in the third position. The IE-96 and TIE-96 came from warehouse stock reserved for STS use. The amount of Zeolite loaded to columns is provided in Table 26. An In-cell schematic of the test apparatus is shown in Figure 19 and the individual test column design is shown in Figure 20.

- Operation approximated the full-scale STS process: column outlet temperature $12^{\circ} \mathrm{C}$, flow rate of 1 $\mathrm{ml} /$ hour approximated 4 to 5 gallons per minute in the STS.

- The THOREX wash solution was prepared in the A\&PC Laboratory approximating actual, full-scale wash operation. THOREX samples were neutralized in high-pH and diluted Tank $8 \mathrm{D}-2$ solutions. The feed solutions (Table 27) were prepared to approximate the 5 to $6 \mathrm{wt} \%$ TDS expected in the THOREX wash solution feed to the STS.

\subsubsection{Test Summary}

The lead TIE-96 column achieved Cs- 137 breakthrough after approximately $700 \mathrm{ml}$ of the laboratory-prepared THOREX wash had been processed. This corresponds to $500 \mathrm{ml}$ of feed per gram of zeolite or 100,000 gallons of THOREX wash solution per zeolite column in the STS (3,600 lbs of zeolite per column). This was comparable to sludge wash processing results where the volume processed through each ion-exchange column varied from 49,000 gallons to over 250,000 gallons, depending on the Cs-137 concentration in the column feed.

\section{Decontamination Factors}

Column DFs for the Cs-137 were over one million and column loading corresponded to a $110 \mathrm{kCi}$ of Cs-137 per STS column. These values are comparable with previous experience processing Tank $8 \mathrm{D}-2$ supernatant solution where the decontamination loading varied from 50 to $250 \mathrm{kCi} /$ column and the DFs over 100,000.

The DFs for alpha-Pu for this test varied from 19 to 66 . The low DFs are attributed to the feed solution's low alpha-Pu concentration of $2.88 \mathrm{E}-05 \mu \mathrm{Ci} / \mathrm{ml}$. The TIE-96 did remove the trace levels of $\mathrm{Pu}$ to a DF greater than 10 as required.

The DFs for Sr-90 were greater than 30,000 throughout this test. The Sr-90 DFs were much higher in this test as compared to sludge wash processing and to column tests with sludge wash solutions.

No abnormalities; such as resin dissolution, discoloration, channeling solid precipitates, or plugging; were noted. This test demonstrated that the expected THOREX wash solutions in Tank $8 \mathrm{D}-2$ could be readily processed through the STS without modifications to equipment or process conditions. The zeolite usage rate was not expected to change from that experienced in processing supernatant and sludge wash solutions. 
Table 26.

WVNS TRQ/TP-071

Zeolite Contained in the Test Columns

\begin{tabular}{lcccc}
$\begin{array}{l}\text { Column } \\
\text { Number }\end{array}$ & Zeolite (grams) & $\begin{array}{l}\text { Moisture } \\
\text { (percent) }\end{array}$ & Density (g/ml) & $\begin{array}{c}\text { Column Volume } \\
\text { (cv)(ml) }\end{array}$ \\
1) TIE-96 & 1.3371 & 15.72 & 0.925 & 1.45 \\
2) IE-96 & 1.3264 & 15.43 & 0.920 & 1.44 \\
3) TIE-96 & 1.3411 & 17.72 & 0.925 & 1.45 \\
\hline
\end{tabular}




\begin{tabular}{|c|c|}
\hline Analysis & Average for Three Feeds \\
\hline $\mathrm{pH}$ & 12.15 \\
\hline Alkalinity $(\mathrm{M})$ & 0.05 \\
\hline Total Dissolved Solids wt.\% (TDS) & 6.08 \\
\hline Total Solids wt.\% (TS) & 5.66 \\
\hline Density $(\mathrm{gm} / \mathrm{ml})$ & 1.037 \\
\hline Total Organic Carbon $(\mu \mathrm{g} / \mathrm{ml})$ & 116 \\
\hline Total Inorganic Carbon $(\mu \mathrm{g} / \mathrm{ml})$ & 335 \\
\hline Gross alpha $(\mu \mathrm{Ci} / \mathrm{ml})$ & $<2.00 \mathrm{E}-02$ \\
\hline Gross beta $(\mu \mathrm{Ci} / \mathrm{ml})$ & $2.94 \mathrm{E}+02$ \\
\hline alpha-Pu $(\mu \mathrm{Ci} / \mathrm{ml})$ & $4.44 \mathrm{E}-5$ \\
\hline $\mathrm{Tc}-99(\mu \mathrm{Ci} / \mathrm{ml})$ & $7.03 \mathrm{E}-02$ \\
\hline $\mathrm{Sr}-90(\mu \mathrm{Ci} / \mathrm{ml})$ & $3.12 \mathrm{E}-01$ \\
\hline $\mathrm{Cs}-137(\mu \mathrm{Ci} / \mathrm{ml})$ & $2.54 \mathrm{E}+02$ \\
\hline$F^{-}(\mu \mathrm{g} / \mathrm{g})$ & 45 \\
\hline $\mathrm{Cl}^{-}(\mu \mathrm{g} / \mathrm{g})$ & 208 \\
\hline $\mathrm{NO}_{2}^{-}(\mu \mathrm{g} / \mathrm{g})$ & 14,160 \\
\hline $\mathrm{NO}_{3}{ }^{-}(\mu \mathrm{g} / \mathrm{g})$ & 20,950 \\
\hline $\mathrm{PO}_{4}^{-}(\mu \mathrm{g} / \mathrm{g})$ & 208 \\
\hline $\mathrm{SO}_{4}^{-}(\mu \mathrm{g} / \mathrm{g})$ & 790 \\
\hline $\mathrm{Al}(\mu \mathrm{g} / \mathrm{g})$ & 148 \\
\hline $\mathrm{B}(\mu \mathrm{g} / \mathrm{g})$ & 45 \\
\hline $\mathrm{Cr}(\mu \mathrm{g} / \mathrm{g})$ & 190 \\
\hline $\mathrm{Fe}(\mu \mathrm{g} / \mathrm{g})$ & 0.2 \\
\hline $\mathrm{K}(\mu \mathrm{g} / \mathrm{g})$ & 66 \\
\hline $\mathrm{Na}(\mu \mathrm{g} / \mathrm{g})$ & 16,290 \\
\hline $\mathrm{Ni}(\mu \mathrm{g} / \mathrm{g})$ & 1.0 \\
\hline $\mathrm{Th}(\mu \mathrm{g} / \mathrm{g})$ & 0.61 \\
\hline
\end{tabular}




\subsection{WVDP SLUDGE WASH AND THOREX WASH PROCESSING}

\subsection{Sludge Wash Operations}

Beginning in 1988, WVDP processed the liquid supernatant solution from Tank 8D-2 through an ion-exchange process to yield a Low-level Waste (LLW) solution. The LLW stream was concentrated and made into a cementitious waste form. Supernatant processing was performed through November 1990.

The second pretreatment step began in 1991 at the WVDP. The HLW in Tank 8D-2 contained a sludge layer on the floor of the tank that contained insoluble oxides, hydroxides, and carbonates of many species (principally iron). Also in the sludge layer were undissolved sodium sulfate crystals that precipitated from the supernatant liquid. For the second pretreatment operation, the HLW in Tank 8D-2 was mobilized by five mixing pumps that allowed the sodium sulfate crystals to dissolve into sludge wash water added to the tank. Two sludge wash operations were performed.

Sludge wash one processing began April 1992 and ended May 1994, resulting in 410,000 gallons of decontaminated solution. The initial sludge wash one solution was at approximately $21 \mathrm{wt} \%$ solids. The solution was gradually diluted by the Main Plant liquid waste and the returns of process liquids over the twoyear period to approximately 15 wt.\% TDS. A summary of sludge wash one composition is in Table 28 .

The extended period of time for processing the first sludge wash solution was attributed to equipment deficiency in other areas of the IRTS and not attributed to the STS ion-exchange columns or TIE-96 and IE-96 zeolite resins. A gasket in the LWTS evaporator was replaced in January 1993. The floating suction pump in Tank 8D-2 was repositioned in December 1993. The repositioning of the pump allowed for additional solution heel removal that resulted in the elimination of the third sludge wash. Both of these activities required that the IRTS be placed in stand-by during modifications.

Eight campaigns were required to process the sludge wash one solution. A campaign is defined as the processing between column changes. Each STS column contained 3,600 lbs $(1,293 \mathrm{~kg})$ of zeolite with a volume of approximately 67 cubic feet. Reference 16 provides a detailed description of the STS columns, system, and operations.

Sludge wash two processing began June 1994 and ended August 1994, resulting in 355,850 gallons of decontaminated solution. A summary of sludge wash two composition is in Table 29.

The sludge wash solutions were treated in the ion-exchange process as was done with the supernatant solution. The ion-exchange processing used IE-96 zeolite to retain Cs-137 and used TIE-96 zeolite to retain Cs-137, Sr90 , and $\mathrm{Pu}$ from the sludge wash solutions. The resulting LLW stream was concentrated and made into a cementitious waste form similar to previous supernatant cement waste in the Cement Solidification System (CSS). 


\begin{tabular}{|c|c|c|c|c|}
\hline Analysis & $\begin{array}{l}\text { Start-up } \\
\text { Average }\end{array}$ & $\begin{array}{c}\text { 24-Month } \\
\text { Average }\end{array}$ & $\begin{array}{l}\text { Standard } \\
\text { Deviation }\end{array}$ & $\begin{array}{l}\text { 3-Month } \\
\text { Average }\end{array}$ \\
\hline $\mathrm{pH}$ & 12.6 & 12.4 & 0.21 & 12.0 \\
\hline Total Dissolved Solids wt.\% (TDS) & 19.9 & 17.5 & 2.1 & 14.1 \\
\hline Total Suspended Solids $(\mu \mathrm{g} / \mathrm{g})$ & 463 & -- & --- & -- \\
\hline Density (gm/ml) & 1.155 & 1.133 & 0.02 & 1.105 \\
\hline Total Organic Carbon $(\mu \mathrm{g} / \mathrm{g})$ & -- & 40 & 5 & 32 \\
\hline Total Inorganic Carbon $(\mu \mathrm{g} / \mathrm{g})$ & --- & 1,910 & 400 & 1,720 \\
\hline Gross Alpha $(\mu \mathrm{Ci} / \mathrm{ml})$ & $<1.42 \mathrm{E}-01$ & $<2.20 \mathrm{E}-01$ & --- & $<7.8 \mathrm{E}-02$ \\
\hline Gross Beta $(\mu \mathrm{Ci} / \mathrm{ml})$ & $7.56 \mathrm{E}+02$ & $6.83 E+02$ & $1.79 \mathrm{E}+02$ & $5.49 E+-2$ \\
\hline alpha-Pu $(\mu \mathrm{Ci} / \mathrm{ml})$ & $1.70 \mathrm{E}-02$ & $1.49 E-02$ & $2.16 \mathrm{E}-03$ & $1.56 \mathrm{E}-02$ \\
\hline $\mathrm{U}(\mu \mathrm{g} / \mathrm{g})$ & 5.37 & 4.71 & 2.4 & 4.76 \\
\hline Tc-99 $(\mu \mathrm{Ci} / \mathrm{ml})$ & $3.25 \mathrm{E}-01$ & $2.50 \mathrm{E}-01$ & $5.72 \mathrm{E}-02$ & $1.92 \mathrm{E}-01$ \\
\hline $\mathrm{Sr}-90(\mu \mathrm{Ci} / \mathrm{ml})$ & $2.20 \mathrm{E}-01$ & $3.70 \mathrm{E}-01$ & $4.86 \mathrm{E}-01$ & $2.75 \mathrm{E}-01$ \\
\hline Cs-137 ( $\mu \mathrm{Ci} / \mathrm{ml})$ & $8.38 \mathrm{E}+02$ & $6.92 \mathrm{E}+02$ & $1.30 \mathrm{E}+02$ & $4.94 \mathrm{E}+02$ \\
\hline$F^{-}(\mu g / g)$ & $<120$ & --- & -- & 94 \\
\hline $\mathrm{Cl}^{-}(\mu \mathrm{g} / \mathrm{g})$ & 452 & 528 & 56 & -- \\
\hline $\mathrm{NO}_{2}^{-}(\mu \mathrm{g} / \mathrm{g})$ & 48,380 & 45,000 & 8,890 & 37,510 \\
\hline $\mathrm{NO}_{3}^{-}(\mu \mathrm{g} / \mathrm{g})$ & 54,960 & 44,100 & 9,910 & 31,540 \\
\hline $\mathrm{SO}_{4}^{-}(\mu \mathrm{g} / \mathrm{g})$ & 22,470 & 17,630 & 17,630 & 13,270 \\
\hline $\mathrm{Al}(\mu \mathrm{g} / \mathrm{g})$ & 275 & 248 & 50 & 209 \\
\hline $\mathrm{B}(\mu \mathrm{g} / \mathrm{g})$ & --- & 17 & 1.2 & -- \\
\hline $\mathrm{Ca}(\mu \mathrm{g} / \mathrm{g})$ & -- & 75 & -- & --- \\
\hline $\mathrm{Cr}(\mu \mathrm{g} / \mathrm{g})$ & 189 & 159 & 16 & 136 \\
\hline $\mathrm{Fe}(\mu \mathrm{g} / \mathrm{g})$ & $<$ d.l. & -- & -- & $<1.0$ \\
\hline $\mathrm{K}(\mu \mathrm{g} / \mathrm{g})$ & -- & 2,200 & 410 & -- \\
\hline $\mathrm{Na}(\mu \mathrm{g} / \mathrm{g})$ & 63,060 & 54,480 & 7,850 & 42,930 \\
\hline$P(\mu g / g)$ & 165 & -- & -- & 150 \\
\hline $\mathrm{Ti}(\mu \mathrm{g} / \mathrm{g})$ & $<$ d.1. & $<$ d.1. & $<$ d.l. & $<$ d.l. \\
\hline
\end{tabular}

$<$ d.l. : less than detection limit 
Table 29.

Sludge Wash Two Analysis from Tank 8D-2

\begin{tabular}{lcc}
\hline Analysis & Average & Standard Deviation \\
$\mathrm{pH}$ & 11.80 & 0.14 \\
Alkalinity & 0.229 & 0.042 \\
Total Dissolved Solids wt.\% (TDS) & 2.94 & 0.03 \\
Density $(\mathrm{gm} / \mathrm{ml})$ & 1.020 & 0.001 \\
Gross alpha $(\mu \mathrm{Ci} / \mathrm{ml})$ & $<2.00 \mathrm{E}-02$ & -- \\
$\mathrm{Gross}$ beta $(\mu \mathrm{Ci} / \mathrm{ml})$ & $1.03 \mathrm{E}+02$ & $6.68 \mathrm{E}+00$ \\
$\mathrm{alpha}-\mathrm{Pu}(\mu \mathrm{Ci} / \mathrm{ml})$ & $1.91 \mathrm{E}-03$ & $9.61 \mathrm{E}-04$ \\
$\mathrm{U}(\mu \mathrm{g} / \mathrm{g})$ & 3.29 & 0.64 \\
$\mathrm{Tc}-99(\mu \mathrm{Ci} / \mathrm{ml})$ & $3.64 \mathrm{E}-02$ & $1.84 \mathrm{E}-03$ \\
$\mathrm{Sr}-90(\mu \mathrm{Ci} / \mathrm{ml})$ & $3.48 \mathrm{E}-02$ & $1.42 \mathrm{E}-02$ \\
$\mathrm{Cs}-137(\mu \mathrm{Ci} / \mathrm{ml})$ & $9.17 \mathrm{E}+01$ & $7.26 \mathrm{E}+00$ \\
$\mathrm{Cl}(\mu \mathrm{g} / \mathrm{g})$ & 84 & 3.5 \\
$\mathrm{NO}_{2}^{-}(\mu \mathrm{g} / \mathrm{g})$ & 8,770 & 200 \\
$\mathrm{NO}_{3}^{-}(\mu \mathrm{g} / \mathrm{g})$ & 5,310 & 115 \\
$\mathrm{SO}_{4}^{-}(\mu \mathrm{g} / \mathrm{g})$ & 2,780 & 183 \\
$\mathrm{Al}^{-}(\mu \mathrm{g} / \mathrm{g})$ & 41 & 3.1 \\
$\mathrm{Cr}(\mu \mathrm{g} / \mathrm{g})$ & 29 & --- \\
$\mathrm{Fe}(\mu \mathrm{g} / \mathrm{g})$ & $-\cdots, 300$ & 795 \\
$\mathrm{Na}^{-}(\mu \mathrm{g} / \mathrm{g})$ & & - \\
\hline
\end{tabular}




\subsection{THOREX Transfer and Neutralization}

The third pretreatment step began December 1994 at the WVDP. In order to minimize the waste variations in the HLW slurry delivered to the Vitrification Facility, Tank 8D-4 THOREX waste and Tank 8D-2 PUREX waste were combined. Tank 8D-4 contained about 50,000 liters of acidic waste remaining from a mixed thorium and $U$ fuel reprocessing operation. The direct addition of Tank 8D-4 THOREX waste into high-pH Tank 8D-2 was the process method selected to combine the two wastes.

Caustic solution and water were added to Tank 8D-2 prior to the addition of the THOREX waste. The resulting elevated-solution-pH ensured the rapid neutralization of the acidic THOREX waste and maintained trace levels of U, Sr-90, and Pu in the resulting THOREX wash solution. The combined waste was mixed in Tank 8D-2 using existing mobilization pumps that were used for sludge wash operations. The neutralized THOREX waste solids precipitated out of solution and settled intermixed with the PUREX sludge solids.

The resulting THOREX wash solution was treated in the STS ion-exchange process as was done with the previous supernatant and sludge wash solutions. The resulting THOREX wash solution was similar in chemical composition to the original supernatant solution from 1988, but was diluted to 5 to $6 \mathrm{wt} \% \mathrm{TDS}$. The resulting LLW stream was concentrated and made into a cementitious waste form similar to previous supernatant and sludge wash cement waste in the CSS.

THOREX wash processing began January 1995 and ended May 1995, resulting in 316,240 gallons of decontaminated solution. A summary of the THOREX wash composition is in Table 30.

\subsection{Summary of Results}

The use of the TIE-96 zeolite in conjunction with maintaining a high pH in Tank 8D-2 solutions has resulted in the generation of decontaminated solutions an order of magnitude below the transuranic limit of $100 \mathrm{nCi} / \mathrm{g}$. The Cs-137 removal efficient was not impacted by the use of the TIE-96. A total of 1,082,000 gallons of wash solution was decontaminated using the IE-96 and TIE-96 zeolite in the WVDP STS ion-exchange columns.

A summary of the Campaign results during sludge wash and THOREX processing is in Table 31 . Breakthrough curves $\left(\mathrm{C} / \mathrm{C}_{0} \%\right)$ for $\mathrm{Cs}-137$ are provided in Figure 42 for sludge wash one and Figure 43 for sludge wash two and THOREX wash processing. Breakthrough curves $\left(\mathrm{C} / \mathrm{C}_{\mathrm{o}} \%\right)$ for alpha $\mathrm{Pu}$ are provided in Figure 44 for sludge wash one and Figure 45 for sludge wash two and THOREX wash processing. Breakthrough curves $\left(\mathrm{C} / \mathrm{C}_{\mathrm{o}} \%\right)$ for Sr-90 are provided in Figure 46 for sludge wash one, and Figure 47 for sludge wash two and THOREX wash processing.

Laboratory data during qualification testing confirmed that the short run times used at STS (approximately 3 to 4 days) is not good for the Pu DFs. Laboratory data has shown that the DFs during the beginning of the cycle are very low (approximately 1 to 3), but the DFs increase significantly after approximately 36 hours of processing. This can seen graphically in Figures 42 and 44 for Pu. The short run time used at STS is attributed to the limited tank volume available downstream of the STS operations in LWTS and CSS.

Section 6 contains more detailed information on the individual campaigns used to process the HLW liquids. A campaign represents the amount of liquid processed through the STS columns until the lead column has reached breakthrough. 
Table 30.

THOREX Wash Analysis from Tank 8D-2

Analysis

$\mathrm{pH}$

Total Dissolved Solids wt.\% (TDS)

Total Solids wt.\% (TS)

Density (gm/ml)

Total Organic Carbon (TOC)

Total Inorganic Carbon (TIC)

Gross alpha $(\mu \mathrm{Ci} / \mathrm{ml})$

Gross beta $(\mu \mathrm{Ci} / \mathrm{ml})$

alpha-Pu $(\mu \mathrm{Ci} / \mathrm{ml})$

$\mathrm{U}(\mu \mathrm{g} / \mathrm{g})$

Tc-99 $(\mu \mathrm{Ci} / \mathrm{ml})$

Sr-90 $(\mu \mathrm{Ci} / \mathrm{ml})$

Cs-137 ( $\mu \mathrm{Ci} / \mathrm{ml})$

$F^{n}(\mu g / g)$

$\mathrm{Cl}^{-}(\mu \mathrm{g} / \mathrm{g})$

$\mathrm{NO}_{2}^{-}(\mu \mathrm{g} / \mathrm{g})$

$\mathrm{NO}_{3}{ }^{-}(\mu \mathrm{g} / \mathrm{g})$

$\mathrm{SO}_{4}^{-}(\mu \mathrm{g} / \mathrm{g})$

$\mathrm{Al}(\mu \mathrm{g} / \mathrm{g})$

$\mathrm{Cr}(\mu \mathrm{g} / \mathrm{g})$

$\mathrm{Fe}(\mu \mathrm{g} / \mathrm{g})$

$\mathrm{Na}(\mu \mathrm{g} / \mathrm{g})$

$P(\mu \mathrm{g} / \mathrm{g})$
Average

11.7

5.75

5.83

1.038

120

185

$<2.44 \mathrm{E}-02$

277

4.30E-05

0.341

8.80E-02

$5.96 \mathrm{E}-01$

259

105

217

18,514

19,018

830

171

136

$<0.48$

17,567

165
35

Standard Deviation

0.18

0.39

0.37

0.003

$<0.0159$

22.4

4.20E-05

0.142

0.009

0.141

26

33

1,946

1,881

169

14

17

2,098

85 
Table 31

Summary of Campaign Results

During Sludge Wash and THOREX Wash Processing

\begin{tabular}{|c|c|c|c|c|c|}
\hline & $\begin{array}{l}\text { Campaign } \\
\underline{22-1 \mathrm{~S}}\end{array}$ & $\begin{array}{l}\text { Campaign } \\
\underline{23-1 S}\end{array}$ & $\begin{array}{l}\text { Campaign } \\
\underline{24-1 S}\end{array}$ & $\begin{array}{l}\text { Campaign } \\
\underline{25-1 S}\end{array}$ & $\begin{array}{l}\text { Campaign } \\
\underline{26-1 S}\end{array}$ \\
\hline Column Sequence & B-C-A & C-A-B & A-B-C & B-C-A & C-A-B \\
\hline Column Zeolite Resin & I-I-T & I-T-T & T-T-I & T-I-T & I-T-I \\
\hline $\begin{array}{l}\text { Volume of Tank 8D-2 Processed } \\
\text { (gallons) }\end{array}$ & 44,133 & 53,510 & 51,852 & 49,075 & 57,617 \\
\hline $\begin{array}{l}\text { Total Volume Processed } \\
\text { (gallons) } \\
\text { (includes flush and dilution } \\
\text { water) }\end{array}$ & 96,740 & 133,348 & 135,496 & 97,951 & 109,607 \\
\hline \multicolumn{6}{|l|}{$\begin{array}{l}\text { Column } \\
\text { Breakthrough (\%) }\end{array}$} \\
\hline Lead & 45.0 & 54.0 & 91.4 & $>78$ & 78 \\
\hline 2nd & 5.6 & 1.0 & 18.1 & 4.06 & 14.7 \\
\hline $\begin{array}{l}\text { Average System DF } \\
\text { (Cs-137) }\end{array}$ & 38,800 & 3,117 & 49,171 & 6,950 & 23,170 \\
\hline $\begin{array}{l}\text { Average System DF } \\
(\mathrm{Pu})\end{array}$ & 64 & 147 & 89 & 230 & 107 \\
\hline $\begin{array}{l}\text { Average Cs-137 in Effluent } \\
(\mu \mathrm{Ci} / \mathrm{ml})\end{array}$ & $2.24 \mathrm{E}-02$ & $1.65 \mathrm{E}-01$ & $1.51 \mathrm{E}-02$ & $5.27 \mathrm{E}-01$ & $4.20 \mathrm{E}-02$ \\
\hline Average $\mathrm{Pu}$ in Effluent $(\mu \mathrm{Ci} / \mathrm{ml})$ & $1.51 \mathrm{E}-04$ & $1.05 \mathrm{E}-03$ & $3.12 \mathrm{E}-04$ & $2.45 \mathrm{E}-05$ & $1.89 \mathrm{E}-04$ \\
\hline $\begin{array}{l}\text { Grams alpha-Pu removed from } \\
\text { Tank 8D-2 }\end{array}$ & 6.30 & 8.43 & 7.62 & 8.04 & 6.56 \\
\hline
\end{tabular}

Column Zeolite Resin $\quad$ I : IE-96 Zeolite Column

$\mathrm{T}$ : TIE-96 Zeolite Column 
Table 31. (continued)

Summary of Campaign Results

During Sludge Wash and THOREX Wash Processing

\begin{tabular}{|c|c|c|c|c|c|}
\hline & $\begin{array}{l}\text { Campaign } \\
\underline{27-1 S}\end{array}$ & $\begin{array}{l}\text { Campaign } \\
\underline{28-1 S}\end{array}$ & $\begin{array}{l}\text { Campaign } \\
29-1 \mathrm{~S} \\
29-2 \mathrm{~S}(*)\end{array}$ & $\begin{array}{c}\text { Campaign3 } \\
0-2 S \\
\underline{30-3 S(*)} \\
\end{array}$ & $\begin{array}{c}\text { Campaign } \\
\underline{31-3 S}\end{array}$ \\
\hline Column Sequence & $A-B-C$ & B-C-A & $C-A-B$ & $A-B-C$ & B-C-A \\
\hline Column Zeolite Resin & T-I-T & I-T-I & T-I-T & I-T-I & T-I-T \\
\hline $\begin{array}{l}\text { Volume of Tank 8D-2 Processed } \\
\text { (gallons) }\end{array}$ & 50,240 & 66,649 & 227,983 & 240,398 & 240,897 \\
\hline $\begin{array}{l}\text { Total Volume Processed } \\
\text { (gallons) } \\
\text { (includes flush and dilution } \\
\text { water) }\end{array}$ & 70,444 & 94,412 & 208,752 & 256,219 & 261,346 \\
\hline \multicolumn{6}{|l|}{$\begin{array}{l}\text { Column } \\
\text { Breakthrough (\%) }\end{array}$} \\
\hline Lead & 61.3 & 81.6 & 53.9 & 15.36 & 70.4 \\
\hline 2nd & 7.7 & 13.4 & 5.3 & 5.94 & $<1.0$ \\
\hline $\begin{array}{l}\text { Average System DF } \\
\text { (Cs-137) }\end{array}$ & 38,055 & 3,623 & 10,938 & 8,568 & 40,363 \\
\hline $\begin{array}{l}\text { Average System DF } \\
(\mathrm{Pu})\end{array}$ & 387 & 42 & 253 & 42 & 71 \\
\hline $\begin{array}{l}\text { Average Cs- } 137 \text { in Effluent } \\
(\mu \mathrm{Ci} / \mathrm{ml})\end{array}$ & $5.66 \mathrm{E}-02$ & $1.42 \mathrm{E}-01$ & $2.19 \mathrm{E}-02$ & $4.41 \mathrm{E}-02$ & $1.74 \mathrm{E}-02$ \\
\hline Average $\mathrm{Pu}$ in Effluent $(\mu \mathrm{Ci} / \mathrm{ml})$ & $7.38 \mathrm{E}-05$ & $5.34 \mathrm{E}-04$ & $4.07 \mathrm{E}-05$ & $1.64 \mathrm{E}-05$ & 4.13E-06 \\
\hline $\begin{array}{l}\text { Grams alpha-Pu removed from } \\
\text { Tank 8D-2 }\end{array}$ & 5.88 & $3.41^{\circ}$ & 2.21 & 0.98 & 1.82 \\
\hline
\end{tabular}

Column Zeolite Resin I : IE-96 Zeolite Column

$\mathrm{T}$ : TIE-96 Zeolite Column

(*) At the completion of sludge wash 1 and 2 processing, the lead columns were not fully loaded with Cs137 and, therefore, were not dumped. Campaign 29-1S includes 37,192 gallons of sludge wash 1 and Campaign 29-2S includes 190,791 gallons of sludge wash 2. Campaign 30-2S includes 165,060 gallons of sludge wash 2, while Campaign 30-3S includes 75,338 gallons of THOREX wash. 


\section{STS Zeolite Column Performance Sludge Wash One Campaigns \\ Cs-137}

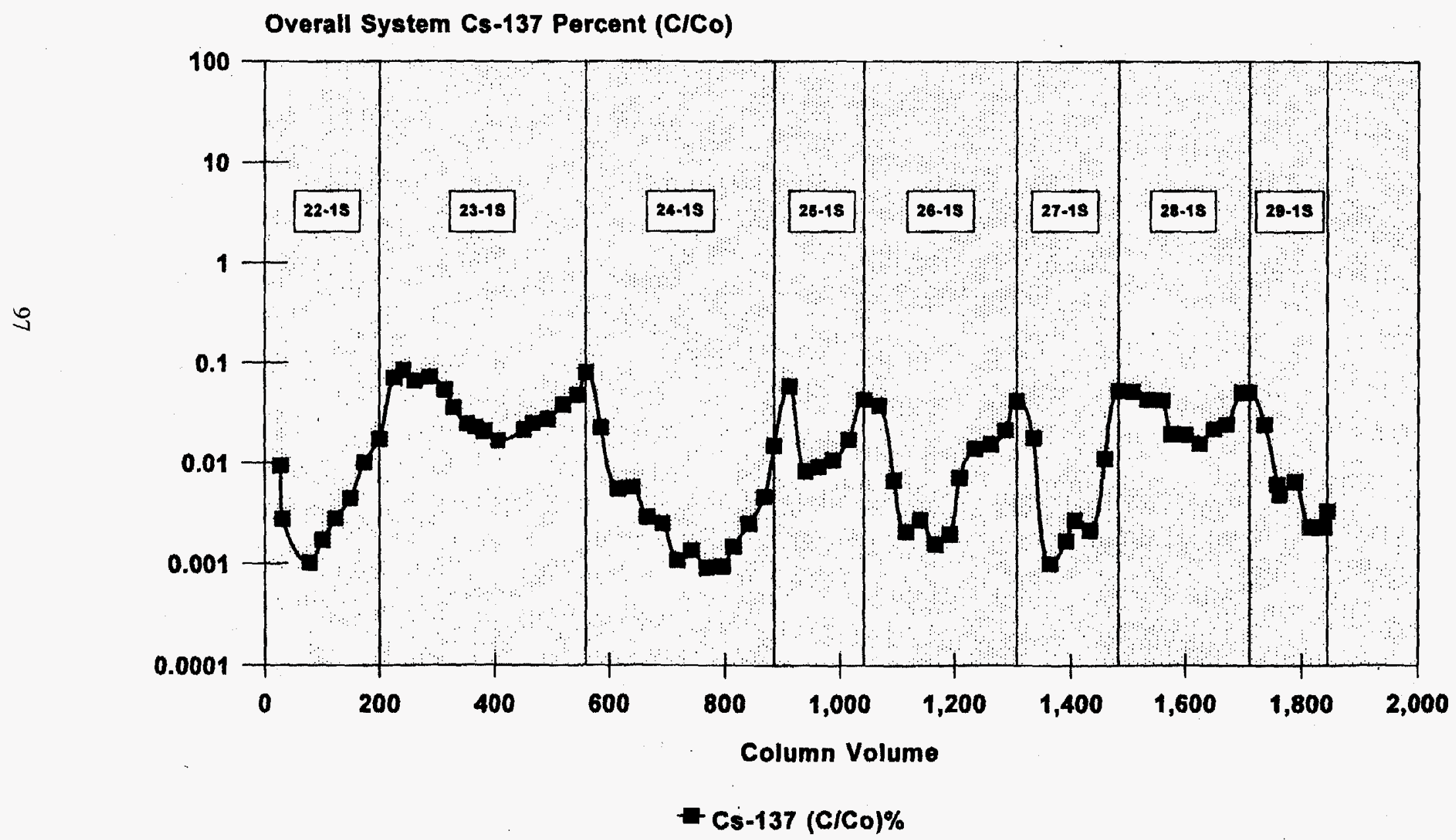

Figure 42. STS Zeolite Column Performance Sludge Wash One Campaigns' Cs-137 


\section{STS Zeolite Column Performance Sludge Wash Two and THOREX Wash Campaigns \\ Cs-137}

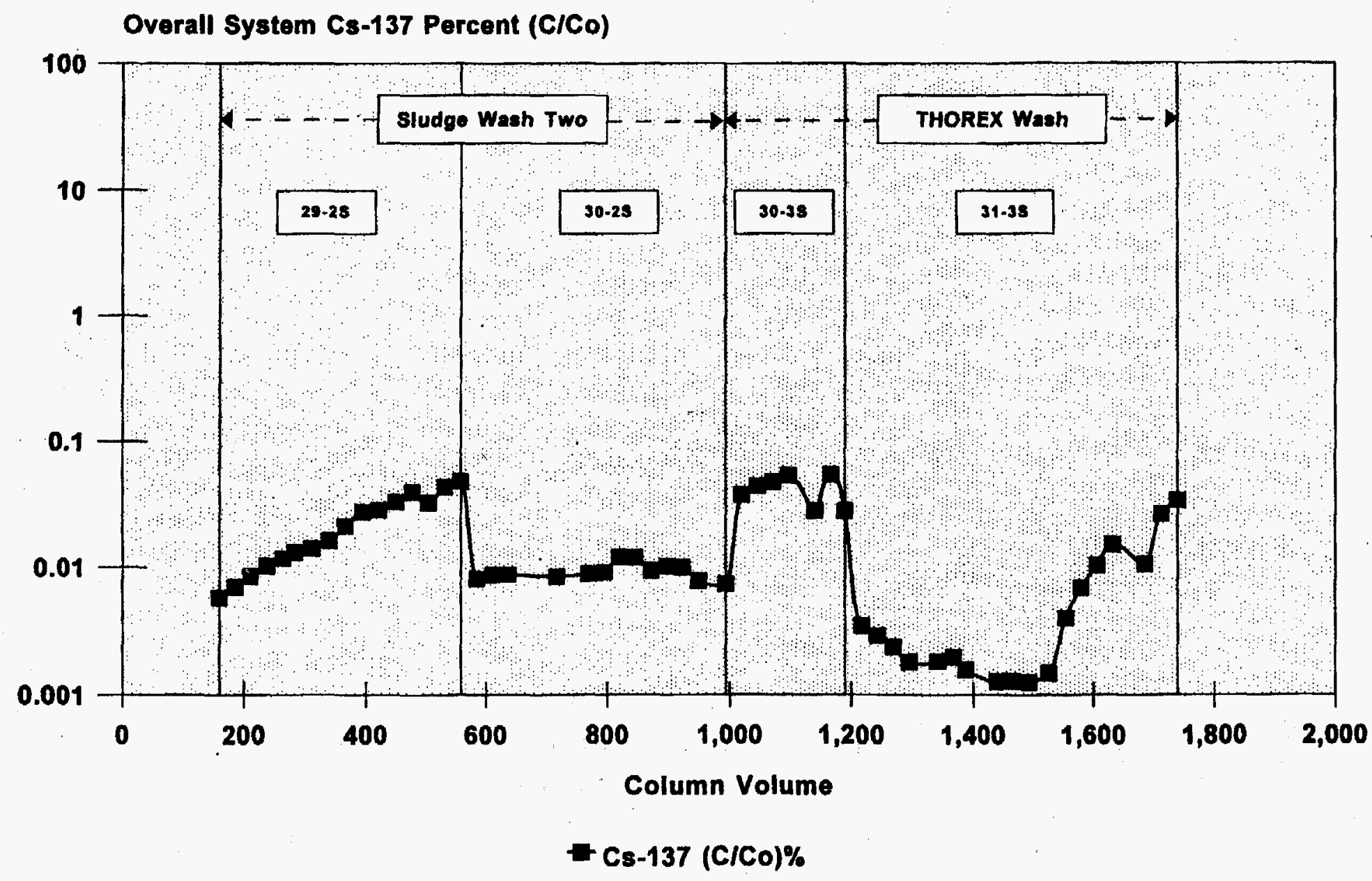

Figure 43. STS Zeolite Column Performance Sludge Wash Two and THOREX Wash Campaigns' Cs-137 


\section{STS Zeolite Column Performance Sludge Wash One Campaigns' alpha-Pu}

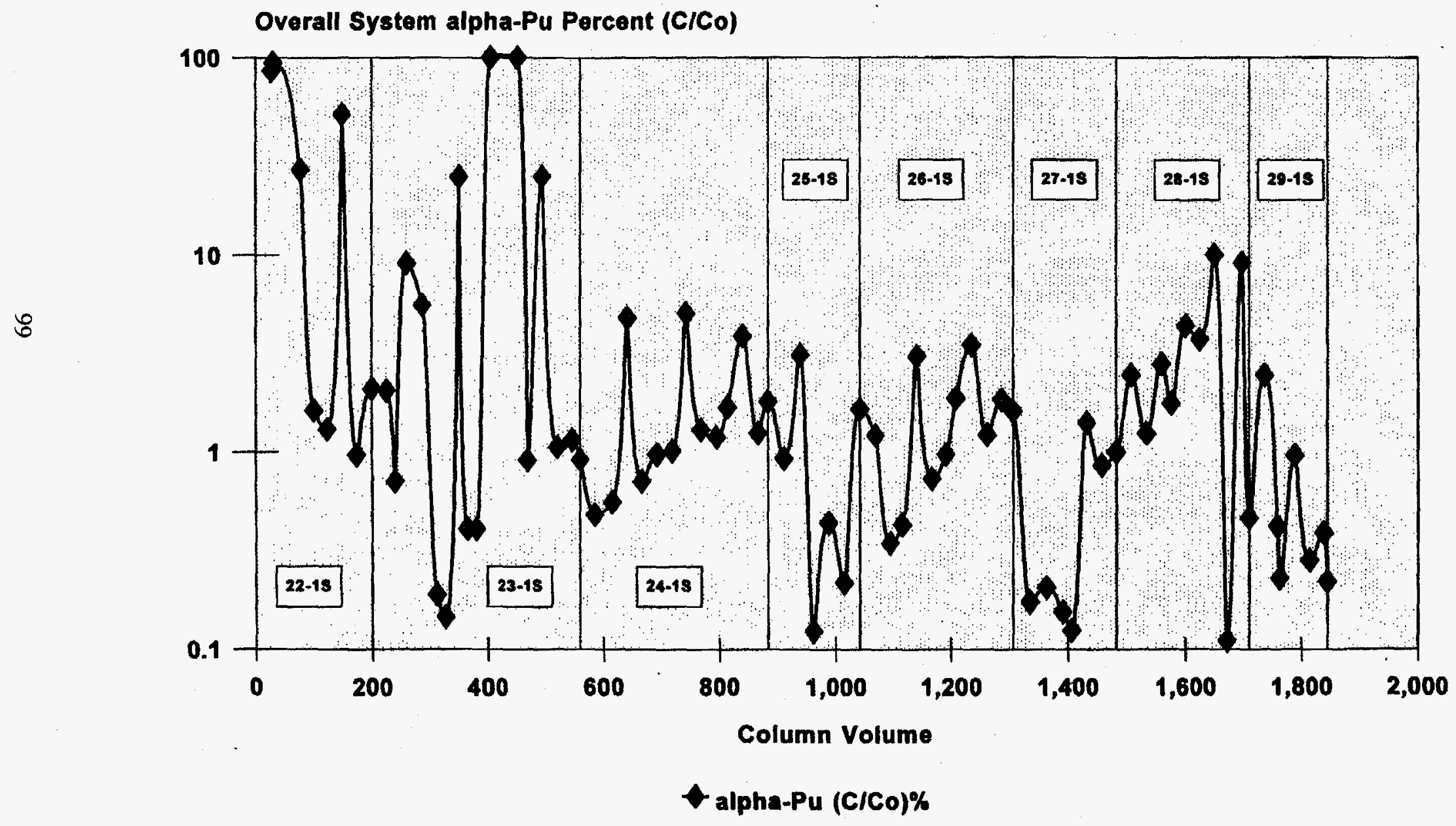

Figure 44. STS Zeolite Column Performance Sludge Wash One Campaigns' alpha-Pu 


\section{STS Zeolite Column Performance Sludge Wash Two and THOREX Wash Campaigns alpha-Pu}

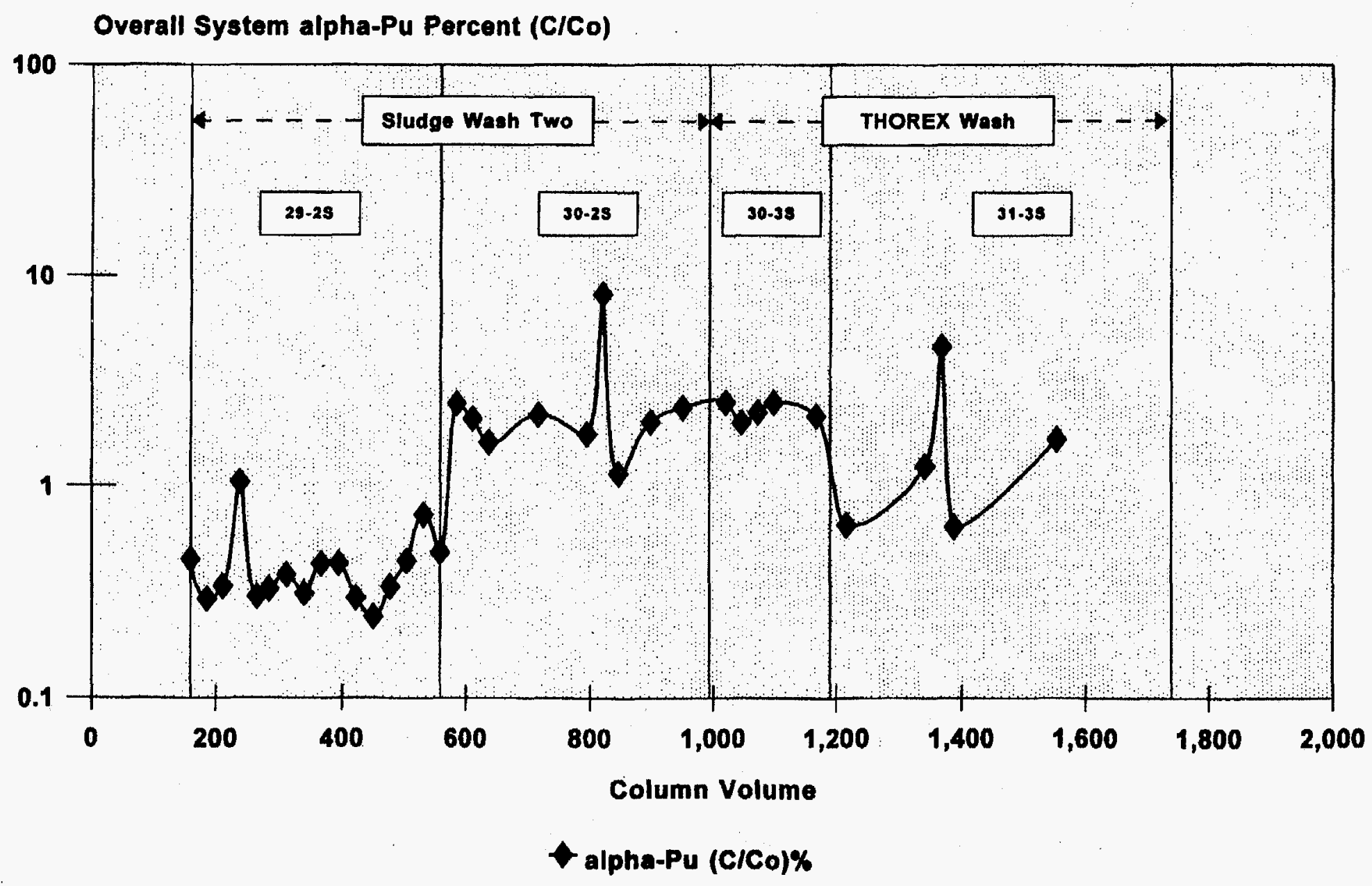

Figure 45. STS Zeolite Column Performance Sludge Wash Two and THOREX Wash Campaigns' alpha-Pu 

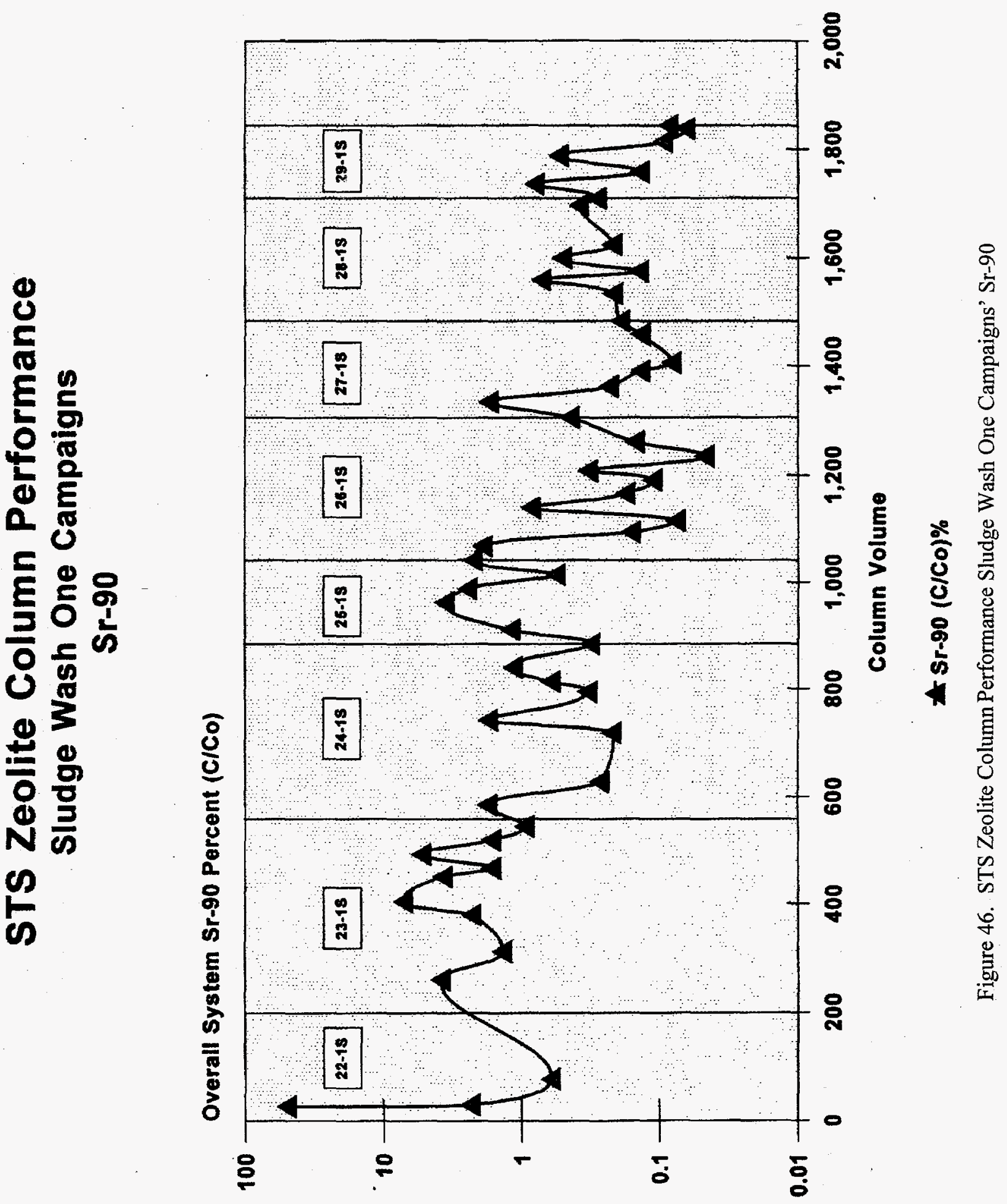


\section{STS Zeolite Column Performance Sludge Wash Two and THOREX Wash Campaigns \\ Sr-90}

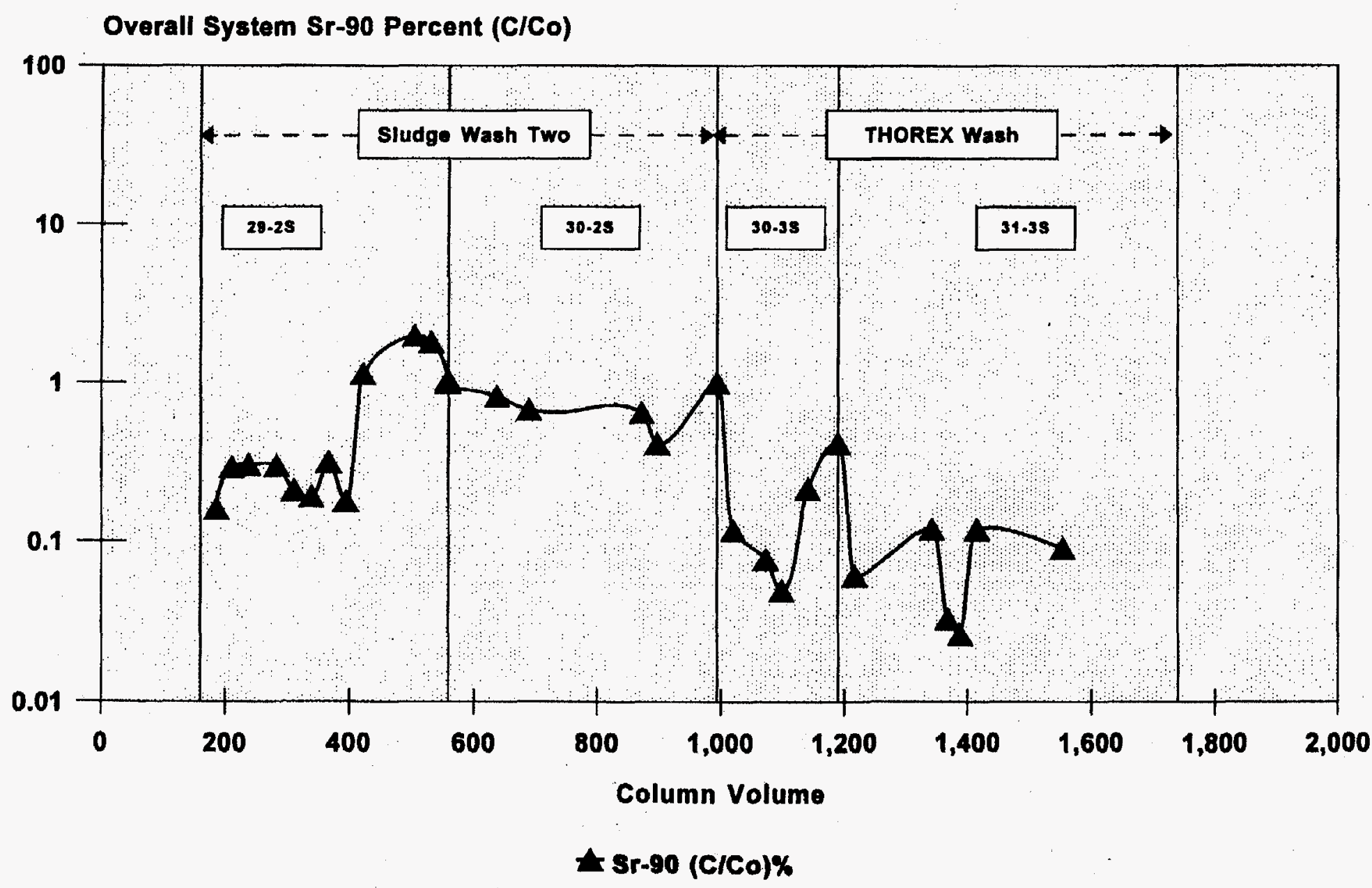

Figure 47. STS Zeolite Column Performance Sludge Wash Two and THOREX Wash Campaigns' Sr-90 


\subsection{WVDP FULL-SCALE CAMPAIGN RESULTS}

\subsection{IRTS Campaign 22-1S ${ }^{17}$}

\subsubsection{Summary}

IRTS Campaign 22-1S started April 27, 1992 and ended September 16, 1992, after processing 44,133 gallons of Tank 8D-2 sludge wash supernatant from the first sludge wash. The STS target dilution factor was 1:1, or 1 gallon of dilution water for each 1 gallon of sludge wash supernatant. STS ion-exchange column operation was in column sequence: $\mathrm{B}, \mathrm{C}, \mathrm{A}$; with column $\mathrm{B}$ the lead column, column $\mathrm{C}$ next, and finally column $\mathrm{A}$ in the third or polishing column position. Columns $\mathrm{B}$ and $\mathrm{C}$ contained IE-96 zeolite, which has almost no affinity for $\mathrm{Pu}$ capture. Column A contained titanium-treated IE-96 zeolite, or TIE-96. IRTS Campaign 22-1S sludge wash supernatant processing resulted in the removal of 133.6 kilocuries of Cs-137 activity and 7.72 grams of $\mathrm{Pu}$ from the solution in Tank 8D-2. Of the 7.72 grams of Pu removed from 8D-2, 6.30 grams were deposited on TIE-96 zeolite in STS ion-exchange column A.

\subsubsection{Column Performance}

The ion-exchange columns performed as expected, achieving an average system DF of approximately 38,800 for Cs-137. There is no previous full-scale column operating history for $\mathrm{Pu} D F$, so no comparison could be drawn. The DF across column A containing the TIE-96 zeolite ranged from a low of $<1$ to a high of 335 . The average DF for Pu across column A for IRTS Campaign 22-1S was 64. A total of 6.30 grams of fissile Pu have been removed with the TIE-96 zeolite in column A. See Table 32 for campaign statistics.

\subsubsection{Comments and Observations}

IRTS Campaign 22-1S was the first full-scale use of TIE-96 zeolite. This use shows comparable DFs (average DF of 64) when compared to the lab testing that was performed prior to full-scale operations. Laboratory data during qualification testing also confirmed that the short run times used in the STS (approximately 3 to 4 days) are not good for the Pu DFs. Lab data has shown that the DFs during the beginning of the cycle are very low (approximately 1 to 3), but the DFs increase significantly after approximately 36 hours of processing to approximately 70 . The short run times used at the STS is attributed to the limited tank volume available downstream of the STS operations in LWTS and CSS. 
Table 32.

Campaign 22-1S

Detailed Table of Run Statistics

\begin{tabular}{|c|c|c|c|c|c|c|c|c|c|}
\hline Transfer Number & 1 & $2^{1}$ & 3 & 4 & 5 & 6 & 7 & 8 & 9 \\
\hline Date & $4 / 28 / 92$ & $7 / 16 / 92$ & $7 / 16 / 92$ & $7 / 29 / 92$ & $7 / 30 / 92$ & $7 / 31 / 92$ & $8 / 17 / 92$ & $8 / 18 / 92$ & $8 / 20 / 92$ \\
\hline STS Flow Rate (gpm) & 8 & 8 & 8 & 8 & 8 & 8 & 8 & 8 & 8 \\
\hline D-001 Sample Number & 2 & 6 & $13 \mathrm{~A}$ & 16 & 19 & 25 & 28 & 31 & -- \\
\hline $\mathrm{Cs}-137(\mu \mathrm{Ci} / \mathrm{ml})$ & $4.47 E+02$ & $3.47 \mathrm{E}+02$ & $4.13 E+02$ & $4.46 \mathrm{E}+02$ & $4.45 E+02$ & $4.24 \mathrm{E}+02$ & $4.38 \mathrm{E}+02$ & $4.56 \mathrm{E}+02$ & $\ldots$ \\
\hline TDS (wt\%) & 10.8 & 11.0 & 11.77 & 11.22 & 11.33 & 10.74 & 10.98 & 11.33 & - \\
\hline Density $(g / m l)$ & 1.080 & 1.087 & 1.081 & 1.086 & 1.084 & 1.080 & 1.083 & 1.086 & $\ldots$ \\
\hline \multicolumn{10}{|l|}{$\begin{array}{l}\text { Cs-137 Activity } \\
\text { Lead Column B }\end{array}$} \\
\hline $\begin{array}{l}\text { ( } \mu \mathrm{Ci} / \mathrm{ml}) \\
\text { 2nd Column C }\end{array}$ & $6.79 \mathrm{E}-01$ & $2.2 \mathrm{E}+00$ & --. & $5.94 \mathrm{E}+00$ & $1.25 \mathrm{E}+01$ & $2.34 \mathrm{E}+01$ & $6.03 \mathrm{E}+01$ & $7.63 \mathrm{E}+01$ & $1.05 \mathrm{E}+02$ \\
\hline$(\mu \mathrm{Ci} / \mathrm{ml})$ & $2.12 E-03$ & $1.79 \mathrm{E}-01$ & $\cdots$ & $1.60 \mathrm{E}-01$ & $2.58 \mathrm{E}-01$ & $2.47 \mathrm{E}-01$ & $2.69 \mathrm{E}-01$ & $3,90 \mathrm{E}-01$ & $5.88 \mathrm{E}-01$ \\
\hline \multicolumn{10}{|l|}{ Column Breakthrough } \\
\hline Lead Column B (\%) & 0.15 & 0.63 & $\cdots$ & 1.44 & 2.8 & 5.26 & 14.2 & 17.42 & 23.0 \\
\hline 2nd Column C (\%) & 0.31 & 8.14 & $\cdots$ & 2.69 & 2.06 & 1.06 & 0.45 & 0.51 & 5.6 \\
\hline 8D-3 Sample Number & 4 & 5 & $\cdots$ & 7 & 8 & 9 & 11 & 12 & 14 \\
\hline Cs-137 ( $(\mu \mathrm{Ci} / \mathrm{ml})$ & $2.32 \mathrm{E}-02$ & $5.16 \mathrm{E}-03$ & -.- & $1.84 \mathrm{E}-03$ & $6.40 \mathrm{E}-03$ & $1.23 \mathrm{E}-02$ & $1.02 \mathrm{E}-02$ & $4.17 \mathrm{E}-02$ & $7.82 \mathrm{E}-02$ \\
\hline $\operatorname{TDS}(w t \%)$ & 6.17 & 6.20 & --- & 5.39 & 9.60 & 11.46 & 6.1 & 10.49 & 11.46 \\
\hline Density $(g / m l)$ & 1.044 & 1.042 & -- & 1.038 & 1.072 & 1.082 & 1.043 & 1.077 & 1.084 \\
\hline \multicolumn{10}{|l|}{ STS System DF } \\
\hline Cs-137 DF & 10,641 & 36,314 & $\cdots$ & 98,700 & 58,857 & 36,179 & 22,800 & 9,979 & 5,831 \\
\hline alpha-Pu DF & 1.16 & 1.06 & $\cdots$ & 3.67 & 61.57 & 76.6 & 1.93 & 103.95 & 47.97 \\
\hline 5D-15B Sample Number & 6 & 8 & $\cdots$ & 10 & 11 & 12 & $13 \mathrm{~A}$ & 14 & 15 \\
\hline $\mathrm{Cs}-137(\mu \mathrm{Ci} / \mathrm{ml})$ & $1.20 \mathrm{E}-02$ & $5.12 \mathrm{E}-03$ & -- & $3.81 \mathrm{E}-03$ & $7.30 \mathrm{E}-03$ & $1.16 \mathrm{E}-02$ & $2.00 \mathrm{E}-02$ & $4.84 \mathrm{E}-02$ & $8.71 \mathrm{E}-02$ \\
\hline $\operatorname{TDS}(w t \%)$ & 6.5 & 8.04 & -- & 8.5 & 10.19 & 10.2 & 8.77 & 10.49 & 11.34 \\
\hline Density $(g / m l)$ & 1.047 & 1.058 & --- & 1.062 & 1.075 & 1.073 & 1.064 & 1.076 & 1.084 \\
\hline \multicolumn{10}{|l|}{ Volume Received In 5D-15B } \\
\hline Cumulative Volume (liters) & 42,120 & 47,478 & 85,845 & 119,902 & 159,549 & 196,085 & 236,595 & 277,105 & 318,747 \\
\hline
\end{tabular}

${ }^{1}$ Use same sample data for transfer \#2 and \#3. Transfer \#2 was interrupted due to an off gas trench alarm. 


\subsection{IRTS Campaign 23-15 ${ }^{18}$}

\subsubsection{Summary}

IRTS Campaign 23-1S started September 7, 1992 and ended March 25, 1993, after processing 53,510 gallons of Tank 8D-2 sludge wash supernatant from the first sludge wash. The STS ion-exchange columns were operated in sequence $\mathrm{C}, \mathrm{A}, \mathrm{B}$; with column $\mathrm{C}$ operating as the lead column, column $\mathrm{A}$ operating as the second column, and column B operating as the final (polishing) column. Columns A and B contained TIE-96 zeolite, column C contained the IE-96 zeolite. The STS target dilution factor was 1:1, or one part water to one part sludge wash supernatant by volume. The STS was operated in seven cycles during IRTS Campaign 23, including one cycle in which column $\mathrm{D}$ was placed on-line in the second position in a four-column operating sequence of C-D-A-B (see Section 6.2.3). IRTS Campaign 23 sludge wash supernatant processing resulted in the removal of $149 \mathrm{kCi}$ of Cs-137 activity and 8.43 grams of Pu from Tank 8D-2 solution.

\subsubsection{Column Performance}

The STS system effluent from the final ion-exchange column, column B, had a higher-than-expected concentration of Cs-137 (see Comments and Observations) and a correspondingly lower system Decontamination Factor (DF). The weighted average system DF for IRTS Campaign 23 was 3,117, as compared with a weighted average DF for IRTS Campaign 22 of 38,800 . The system DF is calculated using the sample analysis of Feed Tank 50D-001 as the influent and the sample analysis of Decontaminated Supernatant Collection Tank $8 \mathrm{D}-3$ as the effluent.

As shown in the Summary Section, two columns of TIE-96 zeolite were utilized during IRTS Campaign 23. Columns A and B both contained TIE-96 zeolite and this improved the overall Pu DF from a value of 64 for IRTS Campaign 22 to 147 for IRTS Campaign 23. The Pu DF was calculated using the analysis of the column $\mathrm{C}$ effluent (influent to column A) as the influent, and the analysis of column B effluent as the system effluent. See Table 33 campaign operational data.

\subsubsection{Comments and Observations}

As seen several times before (see IRTS Supernatant Campaign 20 Run Report), a zeolite heel remaining in the final ion-exchange column adversely effects the Cs- 137 concentration in the column effluent. In the final column, the process solution flowing through the column is partially decontaminated sludge wash supernatant that is low in Cs- 137 concentration and high in sodium concentration. This high-sodium solution has been shown to elute (remove) Cs-137 from the spent zeolite.

The effluent of the final column (column B) exhibited a higher-than-expected Cs-137 concentration, indicating the presence of a heel of Cs-137-loaded spent IE-96 zeolite. The Cs-137 concentration in the column B effluent did not decrease the overall Cs-137 DF at any time to unacceptable levels per Technical Requirement (TR) IRTS-5.

The elution of Cs-137 by the high-sodium, low-Cs- 137 process solution was causing the higher-than-expected effluent Cs-137 concentration. The heel was being eluted by the sodium in the solution passing through the column. When the column is flushed with water, reducing the sodium concentration, the column effluent activity decreases to a normal level. 
Note that the sludge wash solution $\mathrm{pH}$ is .12 .5 compared to a $\mathrm{pH}$ of .10 .0 for supernatant, and that the sodium concentration of the sludge wash solution is approximately double that of the supernatant. Although this operating data is very limited, the conclusion can be drawn that the elution rate of Cs-137 from spent (Cs-137loaded) zeolite is directly affected by the sodium content of the process solution. The sodium concentration should be a very important consideration in subsequent sludge washes, which will have significantly lower Cs137 concentrations. 
Table 33.

Campaign 23-1S

Detailed Table of Run Statistics

\begin{tabular}{|c|c|c|c|c|c|c|c|c|c|c|}
\hline $\begin{array}{l}\text { Transfer Number } \\
\text { Date } \\
\text { STS Flow Rate (gpm) }\end{array}$ & $\begin{array}{l}1 \\
9 / 10 / 92 \\
6\end{array}$ & $\begin{array}{l}2 \\
9 / 14 / 92 \\
6\end{array}$ & $\begin{array}{l}3 \\
9 / 30 / 92 \\
6\end{array}$ & $\begin{array}{l}4 \\
10 / 06 / 92 \\
6\end{array}$ & $\begin{array}{l}5 \\
10 / 07 / 92 \\
6\end{array}$ & $\begin{array}{l}6 \\
11 / 11 / 92 \\
6\end{array}$ & $\begin{array}{l}7 \\
11 / 18 / 92 \\
6\end{array}$ & $\begin{array}{l}8 \\
11 / 19 / 92 \\
6\end{array}$ & $\begin{array}{l}9 \\
02 / 17 / 93 \\
6\end{array}$ & $\begin{array}{l}10 \\
02 / 23 / 93 \\
6\end{array}$ \\
\hline $\begin{array}{l}\text { D001 Sample Number } \\
\text { Cs-137 }(\mu \mathrm{Ci} / \mathrm{ml}) \\
\text { TDS }(w t \%) \\
\text { Density }(\mathrm{g} / \mathrm{ml})\end{array}$ & $\begin{array}{l}40 \\
4.38 \mathrm{E}+02 \\
11.13 \\
1.082\end{array}$ & $\begin{array}{l}41 \\
4.44 \mathrm{E}+02 \\
11.09 \\
1.085\end{array}$ & $\begin{array}{l}49 \\
4.45 \mathrm{E}+02 \\
10.9 \\
1.083\end{array}$ & $\begin{array}{l}53 \\
4.05 \mathrm{E}+02 \\
10.78 \\
1.081\end{array}$ & $\begin{array}{l}55 \\
4.46 \mathrm{E}+02 \\
11.49 \\
1.086\end{array}$ & $\begin{array}{l}55 \\
4.46 \mathrm{E}+02 \\
11.49 \\
1.086\end{array}$ & $\begin{array}{l}58 \\
4.34 \mathrm{E}+02 \\
11.05 \\
1.082\end{array}$ & $\begin{array}{l}61 \\
3.82 \mathrm{E}+02 \\
9.6 \\
1.072\end{array}$ & $\begin{array}{l}61 \\
3.82 \mathrm{E}+02 \\
9.6 \\
1.072\end{array}$ & $\begin{array}{l}4 \\
4.26 \mathrm{E}+2 \\
10.7 \\
1.082\end{array}$ \\
\hline $\begin{array}{l}\text { Cs-137 Activity } \\
\text { Lead Column C } \\
\text { ( } \mu \mathrm{Ci} / \mathrm{ml}) \\
\text { 2nd Column a } \\
\text { ( } \mu \mathrm{Ci} / \mathrm{ml})\end{array}$ & $1.60 \mathrm{E}-01$ & $1.54 \mathrm{E}-01$ & $1.58 \mathrm{E}-01$ & $1.91 \mathrm{E}-01$ & $2.20 \mathrm{E}-01$ & $2.20 \mathrm{E}-01$ & $2.63 \mathrm{E}-01$ & $1.54 \mathrm{E}+01$ & $2.90 \mathrm{E}_{-01} 01$ & $\begin{array}{l}2.59 \mathrm{E}+01 \\
2.90 \mathrm{E}+00\end{array}$ \\
\hline $\begin{array}{l}\text { Column Breakthrough } \\
\text { Lead Column c(\%) } \\
\text { 2nd Column a }(\%)\end{array}$ & $\begin{array}{l}0 \\
0\end{array}$ & $\begin{array}{l}0 \\
0\end{array}$ & $\begin{array}{l}0 \\
0\end{array}$ & $\begin{array}{l}1 \\
0\end{array}$ & $\begin{array}{l}1 \\
0\end{array}$ & $\begin{array}{l}1 \\
0\end{array}$ & $\begin{array}{l}3 \\
0\end{array}$ & $\begin{array}{l}4 \\
0\end{array}$ & $\begin{array}{l}4 \\
0\end{array}$ & $\begin{array}{l}6 \\
1\end{array}$ \\
\hline $\begin{array}{l}\text { 8D-3 Sample Number } \\
\text { Cs-137 }(\mu \mathrm{Ci} / \mathrm{ml}) \\
\text { TDS }(w t \%) \\
\text { Density }(\mathrm{g} / \mathrm{ml})\end{array}$ & $\begin{array}{l}19 \\
1.61 \mathrm{E}-01 \\
6.05 \\
1.042\end{array}$ & $\begin{array}{l}20 \\
3.56 \mathrm{E}-01 \\
10.65 \\
1.078\end{array}$ & $\begin{array}{l}21 \\
1.85 \mathrm{E}-01 \\
6.98 \\
1.05\end{array}$ & $\begin{array}{l}23 \\
1.32 \mathrm{E}-01 \\
5.09 \\
1.036\end{array}$ & $\begin{array}{l}24 \\
1.92 \mathrm{E}-01 \\
10.81 \\
1.078\end{array}$ & $\begin{array}{l}25 \\
1.55 E-01 \\
11.32 \\
1.081\end{array}$ & $\begin{array}{l}26 \\
5.50 \mathrm{E}-02 \\
5.93 \\
1.042\end{array}$ & $\begin{array}{l}27 \\
8.69 E-02 \\
10.5 \\
1.077\end{array}$ & $\begin{array}{l}28 \\
6.81 \mathrm{E}-02 \\
8.37 \\
1.061\end{array}$ & $\begin{array}{l}2 \\
3.83 \mathrm{E}-02 \\
6 \\
1.042\end{array}$ \\
\hline $\begin{array}{l}\text { STS System DF } \\
\text { Cs-137 DF } \\
\text { alpha-Pu DF }\end{array}$ & $\begin{array}{l}1,424 \\
49\end{array}$ & $\begin{array}{l}1,190 \\
142\end{array}$ & $\begin{array}{l}1,523 \\
11\end{array}$ & $\begin{array}{l}1,388 \\
18\end{array}$ & $\begin{array}{l}1,867 \\
530\end{array}$ & $\begin{array}{l}2,821 \\
685\end{array}$ & $\begin{array}{l}4,078 \\
4\end{array}$ & $\begin{array}{l}4,396 \\
248\end{array}$ & $\begin{array}{l}4,840 \\
248\end{array}$ & $\begin{array}{l}6,006 \\
1\end{array}$ \\
\hline $\begin{array}{l}\text { 5D-15B Sample Number } \\
\text { Cs-137 ( }(\mu \mathrm{Ci} / \mathrm{ml}) \\
\text { TDS }(\mathrm{wt} \%) \\
\text { Density }(\mathrm{g} / \mathrm{ml})\end{array}$ & $\begin{array}{l}18 \\
2.20 \mathrm{E}-01 \\
8.35 \\
1.06\end{array}$ & $\begin{array}{l}19 \\
2.67 \mathrm{E}-01 \\
8.67 \\
1.063\end{array}$ & $\begin{array}{l}20 \\
2.17 \mathrm{E}-01 \\
7.97 \\
1.058\end{array}$ & $\begin{array}{l}21 \\
1.45 \mathrm{E}-01 \\
6.68 \\
1.048\end{array}$ & $\begin{array}{l}22 \\
1.75 \mathrm{E}-01 \\
10.85 \\
1.08\end{array}$ & $\begin{array}{l}29 \\
1.22 \mathrm{E}-01 \\
9.89 \\
1.072\end{array}$ & $\begin{array}{l}30 \\
8.97 \mathrm{E}-02 \\
8.6 \\
1.062\end{array}$ & $\begin{array}{l}31 \\
8.52 \mathrm{E}-02 \\
9.08 \\
1.066\end{array}$ & $\begin{array}{l}1 \\
5.44 \mathrm{E}-02 \\
6.23 \\
1.044\end{array}$ & $\begin{array}{l}2 \\
5.50 \mathrm{E}-02 \\
7.88 \\
1.057\end{array}$ \\
\hline $\begin{array}{l}\text { Volume in 5D-15B } \\
\text { (liters) }\end{array}$ & 39,936 & 23,476 & 30,820 & 42,120 & 40,158 & 23,681 & 37,412 & 23,120 & 22,260 & 40,510 \\
\hline Cumulative Volume (liters) & 39,936 & 63,412 & 94,232 & 136,352 & 176,510 & 200,191 & 237,603 & 260,723 & 283,343 & 323,853 \\
\hline
\end{tabular}

${ }^{1}$ Use same sample data for transfer \#2 and \#3. Transfer \#2 was interrupted due to an off gas trench alarm. 


\begin{tabular}{|c|c|c|c|c|c|c|c|}
\hline \multirow[b]{2}{*}{$\begin{array}{l}\text { Transfer Number } \\
\text { Date } \\
\text { STS Flowrate (gpm) }\end{array}$} & \multicolumn{5}{|c|}{$\begin{array}{c}\text { Table } 33 . \text { (continued) } \\
\text { Campaign } 23-1 S \\
\text { Detailed Table of Run Statistics }\end{array}$} & \multicolumn{2}{|c|}{ : } \\
\hline & $\begin{array}{l}11 \\
02 / 24 / 93 \\
6\end{array}$ & $\begin{array}{l}12 \\
02 / 25 / 93 \\
6\end{array}$ & $\begin{array}{l}13 \\
03 / 01 / 93 \\
6\end{array}$ & $\begin{array}{c}14 \\
03 / 09 / 93 \\
6\end{array}$ & $\begin{array}{c}15 \\
03 / 10 / 93 \\
6\end{array}$ & $\begin{array}{c}16 \\
03 / 11 / 93 \\
6\end{array}$ & $\begin{array}{c}17 \\
03 / 16 / 93 \\
6\end{array}$ \\
\hline $\begin{array}{l}\text { D001 Sample Number } \\
\text { Cs-137 }(\mu \mathrm{Ci} / \mathrm{ml}) \\
\text { TDS }(w t \%) \\
\text { Density }(\mathrm{g} / \mathrm{ml})\end{array}$ & $\begin{array}{l}\text { Flush } \\
-- \\
-- \\
--\end{array}$ & $\begin{array}{l}7 \\
4.33 \mathrm{E}+02 \\
11.12 \\
1.085\end{array}$ & $\begin{array}{l}8 \\
4.43 \mathrm{E}+02 \\
11.25 \\
1.083\end{array}$ & $\begin{array}{l}12 \\
4.01 \mathrm{E}+02 \\
10.48 \\
1.077\end{array}$ & $\begin{array}{l}14 \\
3.35 \mathrm{E}+02 \\
10.61 \\
1.078\end{array}$ & $\begin{array}{l}15 \\
3.88 \mathrm{E}+02 \\
10.35 \\
1.076\end{array}$ & $\begin{array}{l}16 \\
4.05 \mathrm{E}+02 \\
10.73 \\
1.079\end{array}$ \\
\hline \multicolumn{8}{|l|}{$\begin{array}{l}\text { Cs-137 Activity } \\
\text { Lead Column C }\end{array}$} \\
\hline $\begin{array}{l}(\mu \mathrm{Ci} / \mathrm{ml}) \\
\text { 2nd Column A } \\
(\mu \mathrm{Ci} / \mathrm{ml})\end{array}$ & -- & $\begin{array}{l}2.28 \mathrm{E}+01 \\
3.34 \mathrm{E}+01\end{array}$ & $\begin{array}{l}2.15 \mathrm{E}+00 \\
4.24 \mathrm{E}+00\end{array}$ & $\begin{array}{l}2.06 \mathrm{E}+00 \\
2.98 \mathrm{E}+00\end{array}$ & $\begin{array}{l}2.03 \mathrm{E}+02 \\
4.45 \mathrm{E}+00\end{array}$ & $\begin{array}{l}2.13 \mathrm{E}+02 \\
2.09 \mathrm{E}+00\end{array}$ & $\begin{array}{l}2.20 \mathrm{E}+02 \\
2.09 \mathrm{E}+00\end{array}$ \\
\hline \multicolumn{8}{|l|}{ Column Breakthrough } \\
\hline $\begin{array}{l}\text { Lead Column C (\%) } \\
\text { 2nd Column A ( } \%)\end{array}$ & $\overline{-}$ & $\begin{array}{l}5 \\
1\end{array}$ & $\begin{array}{l}49 \\
1\end{array}$ & $\begin{array}{l}51 \\
1\end{array}$ & $\begin{array}{l}61 \\
1\end{array}$ & $\begin{array}{l}55 \\
1\end{array}$ & $\begin{array}{l}54 \\
1\end{array}$ \\
\hline $\begin{array}{l}\text { 8D-3 Sample Number } \\
\text { Cs-137 }(\mu \mathrm{Ci} / \mathrm{ml}) \\
\text { TDS }(w t \%) \\
\text { Density }(g / \mathrm{ml})\end{array}$ & $\begin{array}{l}4 \\
8.11 \mathrm{E}-02 \\
10.35 \\
1.076\end{array}$ & $\begin{array}{l}5 \\
6.81 \mathrm{E}-02 \\
8.37 \\
1.061\end{array}$ & $\begin{array}{l}6 \\
5.80 \mathrm{E}-02 \\
6.17 \\
1.044\end{array}$ & $\begin{array}{l}7 \\
5.56 \mathrm{E}-02 \\
5.63 \\
1.04\end{array}$ & $\begin{array}{l}8 \\
1.20 \mathrm{E}-01 \\
10.09 \\
1.074\end{array}$ & $\begin{array}{l}9 \\
1.84 \mathrm{E}-01 \\
10.61 \\
1.078\end{array}$ & $\begin{array}{l}10 \\
3.20 \mathrm{E}-01 \\
10.61 \\
1.078\end{array}$ \\
\hline \multicolumn{8}{|l|}{ STS System DF } \\
\hline $\begin{array}{l}\text { Cs-137 DF } \\
\text { alpha-Pu DF }\end{array}$ & 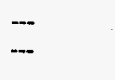 & $\begin{array}{l}4,693 \\
1\end{array}$ & $\begin{array}{l}4,038 \\
111\end{array}$ & $\begin{array}{l}3,682 \\
4\end{array}$ & $\begin{array}{l}2,645 \\
95\end{array}$ & $\begin{array}{l}2,109 \\
87\end{array}$ & $\begin{array}{l}1,250 \\
110\end{array}$ \\
\hline \multicolumn{8}{|l|}{ 5D-15B Sample } \\
\hline Number & 3. & 4 & 5 & 6 & 7 & 8 & 9 \\
\hline Cs-137 ( $\mu \mathrm{Ci} / \mathbf{m l})$ & $5.39 \mathrm{E}-02$ & $7.25 \mathrm{E}-02$ & $6.48 \mathrm{E}-02$ & $7.39 \mathrm{E}-02$ & $1.24 \mathrm{E}-01$ & $1.90 \mathrm{E}-01$ & $2.13 \mathrm{E}-01$ \\
\hline $\operatorname{TDS}(w t \%)$ & 7.09 & 8.53 & 6.84 & 7.75 & 9.965 & 10.6 & 8.79 \\
\hline Density $(g / m l)$ & 1.051 & 1.062 & 1.049 & 1.056 & 1.073 & 1.078 & 1.064 \\
\hline $\begin{array}{l}\text { Volume in 5D-15B } \\
\text { (liters) }\end{array}$ & 30,040 & 41,450 & 24,765 & 41,998 & 41,690 & 40,730 & 20,784 \\
\hline $\begin{array}{l}\text { Cumulative Volume } \\
\text { (liters) }\end{array}$ & 353,893 & 395,343 & 420,108 & 462,106 & 503,796 & 544,526 & 565,310 \\
\hline
\end{tabular}




\subsection{IRTS Campaign $24-1 S^{19}$}

\subsubsection{Summary}

IRTS Campaign 24-1S started March 22, 1993 and ended June 16, 1993, after processing 51,852 gallons of Tank 8D-2 sludge wash supernatant from the first sludge wash. The STS ion-exchange columns were operated in sequence A, B, C; with column A operating as the lead column, column B operating as the second column, and column $\mathrm{C}$ operating as the final (polishing) column. Columns A and B contained TIE-96 zeolite that has the ability to remove $\mathrm{Pu}$. The target dilution factor was 1:1, or one part water to one part sludge wash supernatant by volume. The STS was operated in four cycles during IRTS Campaign 24-1S. IRTS Campaign 24-1S sludge wash supernatant processing resulted in the removal of $137 \mathrm{kCi}$ of Cs-137 activity and 7.62 grams of Pu from Tank 8D-2 solution.

\subsubsection{Column Performance}

The system decontamination factor (DF) was much higher than that exhibited during IRTS Campaign 23-1S. The first batch of decontaminated sludge wash solution collected in Tank 8D-3 had a DF of 4,444. A heel of solution from the previous campaign remained in Tank 8D-3 as the pump heel. This solution had a higher Cs137 concentration than the system effluent and adversely effected the first batch DF. The second batch of decontaminated sludge wash solution had a system DF of 18,000 . The system DF for Cs-137 reached a high of 111,000 and the overall campaign achieved a weighted average DF of 49,171. The system DF is calculated using the sample analysis of Feed Tank 50D-001 as the influent and the sample analysis of Decontaminated Supernatant Collection Tank 8D-3 as the effluent.

As shown in the Summary Section, two columns of TIE-96 zeolite were utilized during IRTS Campaign 24-1S. Columns A and B contained TIE-96 zeolite, as they did in IRTS Campaign 23-1S. The overall DF for Pu achieved during IRTS Campaign 24-1S was 89. The Pu DF was calculated using the analysis of Tank 50D-001 as the influent and the analysis of the column B effluent sample as the effluent Pu concentration. See Table 34 for campaign operational data.

\subsubsection{Comments and Observations}

The system effluent for Cs-137 achieved during IRTS Campaign 24-1S showed good column performance indicating there was no evidence of a heel of spent zeolite remaining in the final, or polishing, ion-exchange column. Following IRTS Campaign 23-1S, ion-exchange column C was dumped in the normal way. Additionally, the column D air sparge was used to sparge air into the bottom of column C through the bottom (normal discharge) Johnson Screen to assure the column did not retain any heel of spent zeolite. Use of this sparge technique in future column dumps will have to be evaluated. Note that column $\mathrm{C}$ was the last column that contained zeolite during the extended standby period following completion of supernatant processing (see IRTS Campaign 21 Run Report). Columns B and C both contained lightly loaded zeolite during the period between supernatant processing and sludge wash solution processing. 
Table 34.

Campaign 24-1S

Detailed Table of Run Statistics

\begin{tabular}{|c|c|c|c|c|c|c|c|c|}
\hline Transfer Number & 1 & 2 & 3 & 4 & 5 & 6 & 7 & 8 \\
\hline Date & $3 / 23 / 93$ & $3 / 24 / 93$ & $3 / 25 / 93$ & $4 / 6 / 93$ & $4 / 7 / 93$ & $4 / 8 / 93$ & $5 / 4 / 93$ & $5 / 5 / 93$ \\
\hline STS Flowrate (gpm) & 6 & 6 & 6 & 6 & 6 & 6 & 6 & 6 \\
\hline D-001 Sample Number & 18 & 22 & 26 & 29 & 32 & 34 & 38 & 41 \\
\hline $\mathrm{Cs}-137(\mu \mathrm{Ci} / \mathrm{ml})$ & $3.71 \mathrm{E}+2$ & $3.93 \mathrm{E}+2$ & $4.00 \mathrm{E}+2$ & $3.17 \mathrm{E}+2$ & $3.90 \mathrm{E}+2$ & $3.90 \mathrm{E}+2$ & $3.66 \mathrm{E}+2$ & $3.93 \mathrm{E}+2$ \\
\hline TDS (wt $\%)$ & 9.76 & 10.48 & 10.64 & 10.03 & 10.39 & 10.32 & 9.31 & 10.22 \\
\hline Density $(g / m l)$ & 1.042 & 1.077 & 1.078 & 1.074 & 1.076 & 1.076 & 1.068 & 1.075 \\
\hline \multicolumn{9}{|l|}{ Cs-137 Activity } \\
\hline Lead Column A & $2.93 \mathrm{E}+1$ & $4.92 \mathrm{E}+1$ & $7.20 \mathrm{E}+1$ & $1.09 \mathrm{E}+2$ & $1.23 \mathrm{E}+2$ & $1.52 \mathrm{E}+2$ & $1.48 \mathrm{E}+2$ & $1.87 \mathrm{E}+2$ \\
\hline$(\mu \mathrm{Ci} / \mathrm{ml})$ & $3.80 \mathrm{E}-1$ & $5.28 \mathrm{E}-1$ & $8.16 \mathrm{E}-1$ & $1.38 \mathrm{E}+0$ & $2.65 \mathrm{E}+0$ & $2.05 \mathrm{E}+0$ & $3.33 \mathrm{E}+0$ & $7.22 \mathrm{E}+0$ \\
\hline \multicolumn{9}{|l|}{$\begin{array}{l}\text { 2nd Column B } \\
(\mu \mathrm{Ci} / \mathrm{ml})\end{array}$} \\
\hline \multicolumn{9}{|l|}{ Column Breakthrough } \\
\hline Lead Column A (\%) & 7.9 & 12.5 & 18.0 & 27.9 & 31.5 & 39.0 & 40.4 & 47.6 \\
\hline 2nd Column B (\%) & 1.3 & 1.1 & 1.1 & 1.5 & 2.1 & 1.3 & 2.2 & 3.9 \\
\hline 8D-3 Sample Number & 11 & 12 & 13 & 14 & 15 & 16 & 17 & 18 \\
\hline $\mathrm{Cs}-137(\mu \mathrm{Ci} / \mathrm{ml})$ & $4.91 \mathrm{E}-2$ & $1.98 \mathrm{E}-2$ & $2.30 \mathrm{E}-2$ & $3.79 \mathrm{E}-3 \cdots$ & $7.88 \mathrm{E}-3$ & $4.21 \mathrm{E}-3$ & $2.27 \mathrm{E}-3$ & $3.27 \mathrm{E}-3$ \\
\hline $\operatorname{TDS}(w t \%)$ & 5.9 & 9.57 & 10.61 & 4.30 & 8.53 & 10.35 & 4.43 & 9.44 \\
\hline Density $(\mathrm{g} / \mathrm{ml})$ & 1.042 & 1.070 & 1.078 & 1.030 & 1.062 & 1.076 & 1.031 & 1.069 \\
\hline \multicolumn{9}{|l|}{ STS System DF } \\
\hline Cs-137 DF & 4,444 & 18,007 & 17,342 & 34,389 & 40,104 & 92,637 & 74,062 & 110,391 \\
\hline alpha-Pu DF & 209 & 181 & 21 & 142 & 104 & 100 & 20 & 78 \\
\hline \multicolumn{9}{|l|}{ 5D-15B Sample } \\
\hline Number & 10 & 11 & 12 & 13 & 14 & 15 & 16 & 17 \\
\hline Cs-137 ( $(\mu \mathrm{Ci} / \mathrm{ml})$ & $4.03 \mathrm{E}-2$ & $1.72 \mathrm{E}-2$ & $8.87 \mathrm{E}-3$ & $5.71 \mathrm{E}-3$ & $5.42 \mathrm{E}-3$ & $4.03 \mathrm{E}-3$ & $3.00 \mathrm{E}-3$ & $2.92 \mathrm{E}-3$ \\
\hline $\operatorname{TDS}(w t \%)$ & 7.75 & 9.57 & 10.35 & 7.22 & 9.44 & 9.44 & 7.22 & no analysis \\
\hline Density ( $g / m \mathbf{m})$ & 1.056 & 1.070 & 1.076 & 1.052 & 1.069 & 1.069 & 1.052 & no analysis \\
\hline \multicolumn{9}{|l|}{ Volume in 5D-15B } \\
\hline \multirow{2}{*}{$\begin{array}{l}\text { (liters) } \\
\text { Cumulative Volume } \\
\text { (liters) }\end{array}$} & 40,745 & 47,330 & 41,600 & 39,426 & 40,348 & 41,450 & 38,130 & 40,510 \\
\hline & 40,745 & 88,075 & 129,675 & 169,101 & 209,449 & 250,899 & 289,029 & 329,539 \\
\hline
\end{tabular}


Table 34. (continued)

Campaign 24-1S

Detailed Table of Run Statistics

\begin{tabular}{|c|c|c|c|c|c|}
\hline Transfer Number & 9 & 10 & 11 & 12 & 13 \\
\hline Date & $5 / 6 / 93$ & $5 / 12 / 93$ & $5 / 18 / 93$ & $5 / 20 / 93$ & $5 / 21 / 93$ \\
\hline STS Flowrate (gpm) & 6 & 6 & 6 & 6 & 6 \\
\hline D.001 Sample Number & 45 & 48 & 52 & 55 & 58 \\
\hline $\mathrm{Cs}-137(\mu \mathrm{Ci} / \mathrm{ml})$ & $3.80 \mathrm{E}+2$ & $3.65 \mathrm{E}+2$ & $3,80 \mathrm{E}+2$ & $3.94 \mathrm{E}+2$ & $3.59 \mathrm{E}+2$ \\
\hline TDS (wt\%) & 10.22 & 9.70 & 10.09 & 10.22 & 10.35 \\
\hline Density (g/ml) & 1.075 & 1.071 & 1.074 & 1.075 & 1.076 \\
\hline \multicolumn{6}{|l|}{ Cs-137 Activity } \\
\hline $\begin{array}{l}\text { Lead Column A } \\
(\mu \mathrm{Ci} / \mathrm{ml})\end{array}$ & $2.41 \mathrm{E}+2$ & $2.69 \mathrm{E}+2$ & $2.76 \mathrm{E}+2$ & $2.97 \mathrm{E}+2$ & $3.28 \mathrm{E}+2$ \\
\hline $\begin{array}{l}\text { 2nd Column B } \\
(\mu \mathrm{Ci} / \mathrm{ml})\end{array}$ & $1.23 \mathrm{E}+1$ & $1.91 \mathrm{E}+1$ & $2.19 \mathrm{E}+1$ & $5.94 \mathrm{E}+1$ & $5.94 \mathrm{E}+1$ \\
\hline \multicolumn{6}{|l|}{ Column Breakthrough } \\
\hline Lead Column A (\%) & 63.4 & 73.7 & 72.6 & 75.4 & 91.4 \\
\hline 2nd Column B (\%) & 1.5 & 7.1 & 7.9 & 20.0 & 18.1 \\
\hline 8D-3 Sample Number & 19 & 21 & 22 & 23 & 24 \\
\hline $\mathrm{Cs}-137(\mu \mathrm{Cl} / \mathrm{ml})$ & $3.50 \mathrm{E}-3$ & $4.43 \mathrm{E}-3$ & $4.94 \mathrm{E}-3$ & $1.69 \mathrm{E}-2$ & $5.28 \mathrm{E}-2$ \\
\hline TDS (wt\%) & 10.09 & 8.14 & 5.50 & 9.70 & 10.35 \\
\hline Density ( $\mathrm{g} / \mathrm{ml}$ ) & 1.074 & 1.059 & 1.039 & 1.071 & 1.076 \\
\hline \multicolumn{6}{|l|}{ STS System DF } \\
\hline Cs-137 DF & 107,091 & 68,367 & 40,564 & 22,045 & 6,799 \\
\hline alpha-Pu DF & 85 & 60 & 26 & 81 & 56 \\
\hline \multicolumn{6}{|l|}{ 5D-15B Sample } \\
\hline Number & 18 & 19 & 20 & 21 & 22 \\
\hline Cs-137 $(\mu \mathrm{Ci} / \mathrm{ml})$ & $3.37 \mathrm{E}-3$ & $3.81 \mathrm{E}-3$ & $7.90 \mathrm{E}-3$ & $2.69 \mathrm{E}-2$ & $3.75 \mathrm{E}-2$ \\
\hline TDS (wt $\%)$ & 7.88 & 7.88 & 7.75 & 9.96 & 7.75 \\
\hline Density (g/ml) & 1.057 & 1.057 & 1.056 & 1.073 & 1.056 \\
\hline Volume in 5D-15B (liters) & 42,081 & 29,800 & 41,450 & 42,770 & 27,213 \\
\hline Cumulative Volume (liters) & 371,620 & 401,420 & 442,870 & 485,640 & 512,853 \\
\hline
\end{tabular}




\subsection{IRTS Campaign 25-1S ${ }^{20}$}

\subsubsection{Summary}

IRTS Campaign 25-1S began June 8, 1993 and ended August 12, 1993, after processing 49,075 gallons of Tank 8D-2 sludge wash supernatant from the first sludge wash. The STS ion-exchange columns were operated in sequence $\mathrm{B}, \mathrm{C}, \mathrm{A}$; with column $\mathrm{B}$ operating as the lead column, column $\mathrm{C}$ operating as the second column, and column A operating as the final (polishing) column. Columns B and A contained TIE-96 zeolite which has the ability to remove $\mathrm{Pu}$. The target dilution factor was 1:2, or one part water to two parts sludge wash supernatant by volume. The STS was operated in four cycles during IRTS Campaign 25-1S. IRTS Campaign 25-1S sludge wash supernatant processing resulted in the removal of $99.1 \mathrm{kCi}$ of Cs-137 activity and 8.04 grams of fissile Pu from Tank 8D-2 solution.

\subsubsection{Column Performance}

During Campaign 25-1S, the STS ion-exchange columns were operated at a dilution factor of two parts 8D-2 sludge wash supernatant (by volume) to one part water. This dilution ratio was used to compensate for some dilution of the Tank 8D-2 contents by additions from the plant liquid waste system. See Table 35 for campaign operational data.

\subsubsection{Comments and Observations}

After several hours of processing, the system effluent radiation monitor indicated higher-than-expected contamination levels. This was backed up by sample analyses of the system effluent which also showed a higher-than-expected Cs-137 concentration. It was first thought that the final ion-exchange column had a heel of Cs-137-loaded spent zeolite. There are many examples in former STS processing campaign run reports that document the adverse effects of a heel of loaded zeolite in the final column.

A review of the zeolite removal operations for the final column, column A, tended to minimize the likelihood of a heel remaining in the column. The column had been dumped per the procedure, the bottom plug was installed, and the column filled with water for performance of a leak check. The plug gasket did not provide an acceptable seal; requiring removal of the plug. This extra column-flush should have removed any heel that remained in the column.

After column-pressure tests proved to be inconclusive for determining the problem, it was decided that the most likely source of contamination of system effluent was Valve FV-102A, which isolates the effluent side of column A (the final column in the column sequence used in this campaign) from the raw supernatant feed line to column $\mathrm{B}$ (the first column in sequence). Valve FV-102A was removed from the backwall and blank block connectors were installed on the jumper wall nozzles. Removal of the FV-102A valve jumper eliminated the problem of high system effluent Cs-137 concentration. Following campaign 25-1S, the leaking FV-102A jumper was replaced with a new jumper.

The above-mentioned system effluent contamination adversely affected the overall weighted decontaminated factor (DF) for the campaign. Three batches of system effluent collected in Tank 8D-3 were recycled to Tank 8D-2 prior to remediation of the leaking valve problem. A small batch of material was transferred to Tank 8D-2 at the conclusion of the campaign due to increased effluent activity as a result of column loading. The overall weighted system Cs-137 DF was 4,950. The weighted DF of the material that was sent to the LWTS/CSS for concentration and processing into a cement waste-form was 6,950. The system achieved a maximum DF for Cs-137 of 12,100 . This average Cs-137 decontamination factor is lower than normal due to the contamination problem referenced above.

As stated in the Summary section, two columns, columns A and B and contained TIE-96 zeolite and one column, column $\mathrm{C}$, contained IE-96 zeolite. The average system DF for Pu was 230 . This Pu decontamination factor is approximately what is expected using two columns of TIE-96 zeolite. 
Table 35.

Campaign 25-1S

Detailed Table of Run Statistics

\begin{tabular}{|c|c|c|c|c|c|c|c|c|c|c|}
\hline Transfer Number & 1 & 2 & 3 & 4 & 5 & 6 & 7 & 8 & 9 & 10 \\
\hline Date & $6 / 09 / 93$ & $6 / 10 / 93$ & $6 / 11 / 93$ & $6 / 17 / 93$ & $6 / 18 / 93$ & 7/7/93 & $7 / 8 / 93$ & $7 / 9 / 93$ & $7 / 21 / 93$ & $8 / 6 / 93$ \\
\hline STS Flowrate (gpm) & 6 & 6 & 6 & 6 & 6 & 6 & 6 & 6 & 6 & 6 \\
\hline D-001 Sample Number & 61 & 63 & 68 & 72 & 76 & 79 & 82 & 86 & 89 & 90 \\
\hline $\mathrm{Cs}-137(\mu \mathrm{Ci} / \mathrm{ml})$ & $4.01 E+2$ & $4.38 \mathrm{E}+2$ & $3.85 \mathrm{E}+2$ & $3.09 \mathrm{E}+2$ & $3.28 \mathrm{E}+2$ & $3.64 \mathrm{E}+2$ & $4.02 \mathrm{E}+2$ & $4.10 \mathrm{E}+2$ & $4.40 E+2$ & $4.48 E+2$ \\
\hline TDS (wt $\%)$ & 11.25 & N/A & 11.50 & 9.70 & 10.35 & 10.61 & 11.25 & 11.34 & 12.01 & 12.01 \\
\hline Density $(g / m)$ & 1.083 & N/A & 1.081 & 1.071 & 1.076 & 1.078 & 1.083 & 1.084 & 1.089 & 1.089 \\
\hline \multicolumn{9}{|l|}{ Cs-137 Activity } & & \\
\hline $\begin{array}{l}\text { Lead Column B } \\
(\mu \mathrm{Ci} / \mathrm{ml})\end{array}$ & $8.86 \mathrm{E}+1$ & $1.11 E+2$ & $1.26 \mathrm{E}+2$ & $1.19 \mathrm{E}+2$ & $1.08 E+2$ & $2.08 \mathrm{E}+2$ & $2,73 \mathrm{E}+2$ & $2.90 \mathrm{E}+2$ & $3.42 \mathrm{E}+2$ & $3.58 \mathrm{E}+2$ \\
\hline $\begin{array}{l}\text { 2nd Column } \mathrm{C} \\
(\mu \mathrm{Ci} / \mathrm{ml})\end{array}$ & $1.67 \mathrm{E}-1$ & $2.32 \mathrm{E}-1$ & $4.12 \mathrm{E}-1$ & $4.78 \mathrm{E}-1$ & $1.22 \mathrm{E}+0$ & $1.69 \mathrm{E}+0$ & $3.01 \mathrm{E}+0$ & $5.88 \mathrm{E}+0$ & $1.39 \mathrm{E}+1$ & $1.91 \mathrm{E}+1$ \\
\hline \multicolumn{10}{|l|}{ Column Breakthrough } & \\
\hline Lead Column B (\%) & 22.1 & 25.3 & 32.7 & 38.5 & 32.9 & 57.1 & 67.9 & 70.7 & 77.7 & 79.9 \\
\hline 2nd Column C (\%) & 0.2 & 0.2 & 0.1 & 0.4 & 1.1 & 0.8 & 1.1 & 20.3 & 4.1 & 5.3 \\
\hline 8D-3 Sample Number & 27 & 29 & 30 & 31 & 33 & 34 & 35 & 36 & 37 & 38 \\
\hline $\mathrm{Cs}-137(\mu \mathrm{Ci} / \mathrm{ml})$ & $3.58 \mathrm{E}-1$ & $6.48 \mathrm{E}-1$ & $7.11 \mathrm{E}-1$ & $1.47 \mathrm{E}-1$ & $2.71 \mathrm{E}-2$ & $1,08 \mathrm{E}-2$ & $4.05 \mathrm{E}-2$ & $6.94 \mathrm{E}-2$ & $1.01 \mathrm{E}-1$ & $3.16 \mathrm{E}-3$ \\
\hline $\operatorname{TDS}(w t \%)$ & 7.88 & 10.60 & 11.37 & 8.14 & 10.48 & 3.63 & 10.60 & 11.25 & 6.70 & 6.96 \\
\hline Density $(\mathrm{g} / \mathrm{ml})$ & 1.057 & 1.078 & 1.084 & 1.059 & 1.077 & $1: 025$ & 1.078 & 1,083 & 1.048 & 1.050 \\
\hline \multicolumn{11}{|l|}{ STS System DF } \\
\hline Cs-137 DF & 672 & 676 & 537 & 1,744 & 12,103 & 10,964 & 9,309 & 5,855 & 2,339 & 792 \\
\hline alpha-Pu DF & 57.6 & 134 & 153 & 109 & 32.4 & 810 & 231 & 464 & 61 & 248 \\
\hline \multicolumn{11}{|l|}{ 5D-15B Sample } \\
\hline Number & N/A & N/A & $\mathrm{N} / \mathrm{A}$ & 23 & 24 & 25 & 26 & 27 & 28 & $\mathrm{~N} / \mathrm{A}$ \\
\hline $\mathrm{Cs}-137(\mu \mathrm{Ci} / \mathrm{ml})$ & XFER to & $X F E R$ to & XFER to & $6.93 E-2$ & $1.20 \mathrm{E}-2$ & $8.31 \mathrm{E}-3$ & $2.11 \mathrm{E}-2$ & $7.66 \mathrm{E}-2$ & $1.99 \mathrm{E}-1$ & XFER to \\
\hline $\operatorname{TDS}(w t \%)$ & $8 D-2$ & $8 \mathrm{D}-2$ & $8 D-2$ & 9.05 & 9.18 & 7.49 & 10.60 & 9.55 & 12.01 & 8D-2 \\
\hline Density $(\mathrm{g} / \mathrm{ml})$ & $\cdots$ & $\ldots$ & $\ldots$ & 1.066 & 1.067 & 1.054 & 1.078 & 1.070 & 1.089 & $\ldots$ \\
\hline $\begin{array}{l}\text { Volume in 5D-15B } \\
\text { (liters) }\end{array}$ & $\begin{array}{l}32,582 \\
\text { to } 8 \mathrm{D}-2\end{array}$ & $\begin{array}{l}32,452 \\
\text { to } 8 D-2\end{array}$ & $\begin{array}{l}34,256 \\
\text { to } 8 \mathrm{D}-2\end{array}$ & 42,770 & 38,690 & 41,570 & 41,450 & 41,450 & 42,362 & $\begin{array}{l}13,442 \text { to } \\
8 \mathrm{D}-2\end{array}$ \\
\hline $\begin{array}{l}\text { Cumulative Volume } \\
\text { (liters) }\end{array}$ & & $\begin{array}{l}65,034 \\
\text { to } 8 \mathrm{D}-2\end{array}$ & $\begin{array}{l}99,290 \\
\text { to } 8 \mathrm{D}-2\end{array}$ & $\begin{array}{l}42,770 \\
\text { to } 5 \mathrm{D}-15 \mathrm{~B}\end{array}$ & 81,460 & 123,030 & 164,480 & 205,930 & $\begin{array}{l}248,292 \\
\text { to } 5 \mathrm{D}-15 \mathrm{D}\end{array}$ & $\begin{array}{l}112,732 \\
\text { to } 8 \mathrm{D}-2\end{array}$ \\
\hline
\end{tabular}




\subsection{IRTS Campaign 26-1S ${ }^{21}$}

\subsubsection{Summary}

IRTS Campaign 26-1S began August 9, 1993 and ended September 24, 1993, after processing 57,617 gallons of Tank 8D-2 sludge wash supernatant from the first sludge wash. The STS ion-exchange columns were operated in sequence $\mathrm{C}, \mathrm{A}, \mathrm{B}$; with column $\mathrm{C}$ as the lead column, column $\mathrm{A}$ as the second column, and column $\mathrm{B}$ as the final column. Column A contained TIE-96 zeolite, columns $\mathrm{C}$ and $\mathrm{B}$ contained IE-96 zeolite. The target dilution factor was one part water to two parts sludge wash supernatant by volume. The STS was operated in three cycles during IRTS Campaign 26-1S. IRTS Campaign 26-1S sludge wash supernatant processing resulted in the removal of $127.4 \mathrm{kCi}$ of Cs-137 activity and 6.56 grams of fissile $\mathrm{Pu}$ from Tank $8 \mathrm{D}$ 2 solution.

The STS operational phase of the campaign was completed on September 24, 1993. Following completion of the IRTS Campaign 26 STS operation, STS went into an extended standby period. This period of extended standby was necessary to reorient the pump 50-G-001 floating suction. 50-G-001 was found to be improperly oriented, causing interference between the 50-G-001 floating suction and the tank, preventing complete lowering of the floating suction. Pump 50-G-001 was rotated to relieve the interference to allow for pumpdown of Tank 8D-2 contents to the minimum possible level.

\subsubsection{Column Performance}

During this campaign, the STS ion-exchange columns were operated at a dilution factor of two parts Tank 8D2 sludge wash supernatant (by volume) to one part water. The STS ion-exchange columns operated normally, producing high system decontamination factors indicative of proper operation. The overall weighted system Cs-137 DF for the campaign was 23,170 . Note that the previous campaign, which was adversely affected by a leaking valve, produced an average DF of 4,950. The system achieved a maximum DF for Cs-137 of 64,500. See Table 36 for campaign operational data.

As stated in the Summary Section, IRTS Campaign 26 operated with column B containing TIE-96 zeolite and columns $\mathrm{A}$ and $\mathrm{C}$ containing IE-96 zeolite. The average system DF for Pu was 107 . The DF for Pu was determined by laboratory analysis of the influent $\mathrm{Pu}$ concentration to the TIE- 96 column and dividing by the Pu concentration in Tank 8D-3. The DF of 107 is approximately the expected DF for operation with one TIE-96 column.

\subsubsection{Comments and Observations}

The STS performed with no major problems during IRTS Campaign 26-1 
Table 36.

Campaign 26-1S

Detailed Table of Run Statistics

\begin{tabular}{|c|c|c|c|c|c|c|c|c|c|}
\hline Transfer Number & 1 & 2 & 3 & 4 & 5 & 6 & 7 & 8 & \\
\hline Date & $8 / 11 / 93$ & $8 / 12 / 93$ & $8 / 13 / 93$ & $8 / 24 / 93$ & $8 / 25 / 93$ & $8 / 26 / 93$ & $8 / 27 / 93$ & $9 / 20 / 93$ & \\
\hline STS Flowrate (gpm) & 6 & 6 & 6 & 6 & 6 & 6 & 6 & 6 & \\
\hline D-001 Sample Number & 92 & 95 & 99 & 101 & 105 & 108 & 111 & 113 & \\
\hline Cs-137 ( $\mu \mathrm{Ci} / \mathrm{ml})$ & $4.28 \mathrm{E}+2$ & $4.23 E+2$ & $4.23 \mathrm{E}+2$ & $3.02 \mathrm{E}+2$ & $3.85 \mathrm{E}+2$ & $4.26 \mathrm{E}+2$ & $4.10 \mathrm{E}+2$ & $3.76 \mathrm{E}+2$ & \\
\hline TDS (wt \%) & 11.37 & 11.37 & 11.76 & 8.79 & 11.63 & 11.63 & 11.76 & 10.86 & \\
\hline Density ( $g / m l)$ & 1.084 & 1.084 & 1.087 & 1.064 & 1.086 & 1.086 & 1.087 & 1.080 & \\
\hline \multicolumn{10}{|l|}{ Cs-137 Activity } \\
\hline Lead Column $\mathrm{C}(\mu \mathrm{Ci} / \mathrm{ml})$ & $2.38 \mathrm{E}+1$ & $4.68 \mathrm{E}+1$ & $6.94 E+1$ & $6.55 \mathrm{E}+1$ & $1.01 E+2$ & $1.67 E+2$ & $1.76 \mathrm{E}+2$ & $2.26 \mathrm{E}+2$ & \\
\hline 2nd Column A ( $\mu \mathrm{Ci} / \mathrm{ml})$ & $3.67 \mathrm{E}+0$ & $1.22 \mathrm{E}+0$ & $1.82 \mathrm{E}+0$ & $2.35 \mathrm{E}+0$ & $3.09 \mathrm{E}+0$ & $7.03 \mathrm{E}+0$ & $9.26 \mathrm{E}+0$ & $1.64 \mathrm{E}+1$ & \\
\hline \multicolumn{10}{|l|}{ Column Breakthrough } \\
\hline Lead Column A (\%) & 5.5 & 11.1 & 16.4 & 21.7 & 26.2 & 39.2 & 42.9 & 60.1 & \\
\hline 2nd Column B (\%) & 15.4 & 2.6 & 2.6 & 3.6 & 3.1 & 4.2 & 5.3 & 7.2 & \\
\hline 8D-3 Sample Number & 40 & 41 & 42 & 43 & 44 & 45 & 46 & 47 & \\
\hline $\mathrm{Cs}-137(\mu \mathrm{Ci} / \mathrm{ml})$ & $8.28 \mathrm{E}-2$ & $2.68 \mathrm{E}-2$ & $8.68 \mathrm{E}-3$ & $5.61 \mathrm{E}-3$ & $5.05 E-3$ & $8.38 \mathrm{E}-3$ & $2.93 \mathrm{E}-2$ & $2,80 \mathrm{E}-2$ & \\
\hline $\operatorname{TDS}(w t \%)$ & 6.17 & 10.86 & 11.76 & 6.16 & 9.96 & 11.66 & 11.76 & 6.05 & \\
\hline Density $(g / m l)$ & 1.044 & 1.080 & 1.086 & 1.044 & 1.073 & 1.086 & 1.087 & 1.043 & \\
\hline \multicolumn{10}{|l|}{ STS System DF } \\
\hline Cs-137 DF & 2,702 & 15,020 & 48,150 & 37,016 & 64,508 & 50,966 & 13,993 & 7,225 & \\
\hline alpha-Pu DF & 83 & 292 & 236 & 33 & 138 & 104 & 54 & 29 & \\
\hline 5D-15B Sample Number & 30 & 31 & 32 & 33 & 34 & 35 & 36 & 37 & \\
\hline $\mathrm{Cs}-137(\mu \mathrm{Ci} / \mathrm{ml})$ & $4.90 \mathrm{E}-2$ & $1.09 \mathrm{E}-2$ & $5.04 \mathrm{E}-3$ & $4.58 \mathrm{E}-3$ & $5.68 \mathrm{E}-3$ & $9.72 \mathrm{E}-3$ & $1.46 \mathrm{E}-2$ & $2.74 \mathrm{E}-2$ & \\
\hline $\operatorname{TDS}(w t \%)$ & 8.43 & 11.12 & 9.96 & 8.53 & 11.12 & 11.50 & 9.31 & 8.31 & \\
\hline Density $(\mathrm{g} / \mathrm{ml})$ & 1.061 & 1.082 & 1.073 & 1.062 & 1.082 & 1.085 & 1.068 & 1.060 & \\
\hline \multirow{3}{*}{$\begin{array}{l}\text { Volume in 5D-15B (liters) } \\
\text { Cumulative Volume (liters) }\end{array}$} & & & & & & & & & \\
\hline & 42,240 & 40,730 & 33,670 & 40,060 & 40,060 & 40,060 & 26,205 & 41,450 & \\
\hline & 42,240 & 82,970 & 116,640 & 156,700 & 196,760 & 236,820 & 263,025 & 304,475 & \\
\hline
\end{tabular}


Table 36. (continued)

Campaign 26-1S

Detailed Table of Run Statistics

\begin{tabular}{|c|c|c|c|}
\hline Transfer Number & 9 & 10 & 11 \\
\hline Date & $9 / 22 / 93$ & 9/23/93 & $10 / 6 / 93$ \\
\hline STS Flowrate (gpm) & 6 & 6 & 6 \\
\hline D-001 Sample Number & 116 & 118 & 121 \\
\hline Cs-137 $(\mu \mathrm{Ci} / \mathrm{ml})$ & $4.11 \mathrm{E}+2$ & $4.18 \mathrm{E}+2$ & 4.18E+2 \\
\hline $\operatorname{TDS}(w t \%)$ & 11.33 & 11.55 & 11.39 \\
\hline Density ( $g / m l)$ & 1.084 & 1.085 & 1.084 \\
\hline \multicolumn{4}{|l|}{ Cs-137 Activity } \\
\hline Lead Column A $(\mu \mathrm{Ci} / \mathrm{ml})$ & $2.32 E+2$ & $3.05 \mathrm{E}+2$ & $3.26 \mathrm{E}+2$ \\
\hline 2nd Column B $(\mu \mathrm{Ci} / \mathrm{ml})$ & $2.10 \mathrm{E}+1$ & $4.14 \mathrm{E}+1$ & $4.78 \mathrm{E}+1$ \\
\hline \multicolumn{4}{|l|}{ Column Breakthrough } \\
\hline Lead Column A (\%) & 56.4 & 73.0 & 78.0 \\
\hline 2nd Column B (\%) & 9.1 & 13.6 & 14.7 \\
\hline 8D-3 Sample Number & 48 & 49 & 50 \\
\hline Cs-137 $(\mu \mathrm{Ci} / \mathrm{ml})$ & $5.94 \mathrm{E}-2$ & $8.85 \mathrm{E}-2$ & $1.28 \mathrm{E}-1$ \\
\hline $\operatorname{TDS}\left(w t^{\%} \%\right)$ & 10.72 & 11.51 & 8.59 \\
\hline Density $(\mathrm{g} / \mathrm{ml})$ & 1.079 & 1.085 & 1.062 \\
\hline \multicolumn{4}{|l|}{ STS System DF } \\
\hline Cs-137 DF & 6,516 & 4,707 & 2,413 \\
\hline alpha-Pu DF & 83 & 55 & 63 \\
\hline 5D-15B Sample Number & 38 & 39 & 40 \\
\hline $\mathrm{Cs}-137(\mu \mathrm{Ci} / \mathrm{ml})$ & $6.60 \mathrm{E}-2$ & $1.09 \mathrm{E}-1$ & $1.12 \mathrm{E}-1$ \\
\hline $\operatorname{TDS}(w t \%)$ & 10.49 & 11.14 & 8.44 \\
\hline Density $(g / m l)$ & 1.077 & 1.082 & 1.061 \\
\hline Volume in 5D-15B (liters) & 41,643 & 40,510 & 30,160 \\
\hline Cumulative Volume (liters) & 346,118 & 386,628 & 416,788 \\
\hline
\end{tabular}




\subsection{IRTS Campaign 27-1S 21}

\subsubsection{Summary}

IRTS Campaign 27-1S began February 18, 1994 and ended March 15, 1994, after processing 50,249 gallons of Tank 8D-2 sludge wash supernatant from the first sludge wash. The STS ion-exchange columns were operated in sequence $\mathrm{A}, \mathrm{B}, \mathrm{C}$; with column $\mathrm{A}$ as the lead column, column $\mathrm{B}$ as the second column, and column $\mathrm{C}$ as the final column. Columns A and C contained TIE-96 zeolite and column B contained IE-96 zeolite. The STS was operated in two cycles during IRTS Campaign 27-1S. IRTS Campaign 27-1S sludge wash supernatant processing resulted in the removal of $76.9 \mathrm{kCi}$ of Cs-137 activity and 5.881 grams of fissile Pu from Tank 8D-2 solution.

\subsubsection{Column Performance}

During this Campaign 27-1S, due to relatively low TDS values in 8D-2, the STS ion-exchange columns were operated with straight Tank 8D-2 sludge wash supernatant. This marks the first time since Campaign 6 that straight Tank 8D-2 liquid has been processed in the STS.

The STS ion-exchange columns operated normally, producing high system decontamination factors indicative of proper operation. The overall weighted system Cs- 137 DF for the campaign was 38,055 . The system achieved a maximum DF for Cs-137 of 99,965.

As stated in the Summary Section, IRTS Campaign 27 operated with columns A and C containing TIE-96 zeolite and column B containing IE-96 zeolite. The average system DF for Pu was 387. The DF for Pu was determined by laboratory analysis of the influent Pu concentration to the TIE-96 column and dividing by the Pu concentration in Tank 8D-3. The DF of 387 is approximately the expected DF for operation with two TIE96 columns. See Table 37 for campaign operational data.

\subsubsection{Comments and Observations}

The STS performed with no major problems during IRTS Campaign 27-1S. 
Table 37.

Campaign 27-1S

Detailed Table of Run Statistics

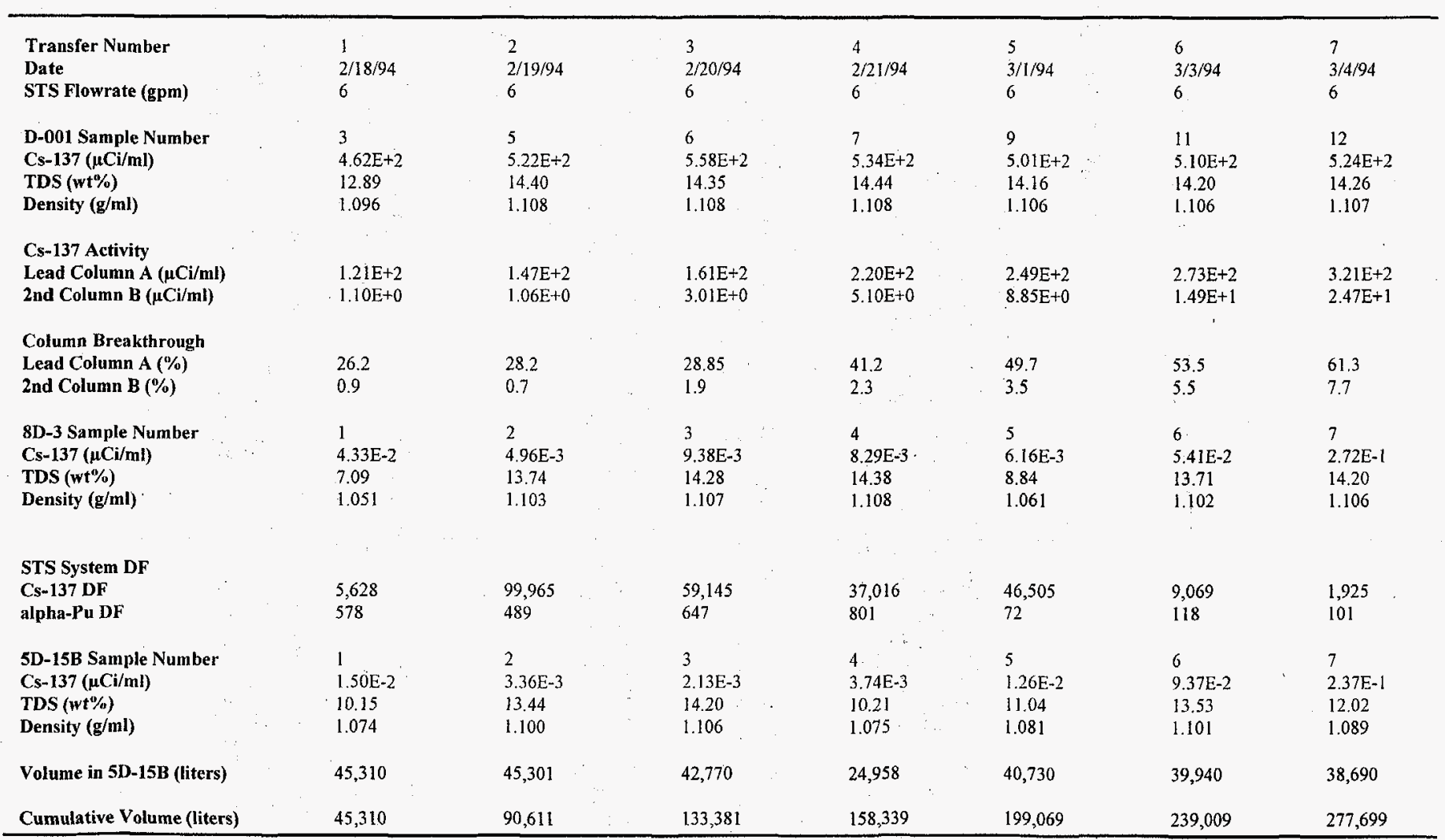




\subsection{IRTS Campaign $28-1 \mathrm{~S}^{21}$}

\subsubsection{Summary}

IRTS Campaign 28-1S began March 19, 1994 and ended April 21, 1994, after processing 66,649 gallons of Tank 8D-2 sludge wash supernatant from the first sludge wash. The STS ion-exchange columns were operated in sequence $\mathrm{B}, \mathrm{C}, \mathrm{A}$; with column $\mathrm{B}$ as the lead column, column $\mathrm{C}$ as the second column, and column $\mathrm{A}$ as the final column. Column C contained TIE-96 zeolite, columns B and A contained IE-96 zeolite. The STS was operated in three cycles during IRTS Campaign 28-1S. IRTS Campaign 28-1S sludge wash supernatant processing resulted in the removal of $123.6 \mathrm{kCi}$ of Cs-137 activity and 3.409 grams of fissile Pu from Tank $8 \mathrm{D}-2$ solution.

\subsubsection{Column Performance}

During Campaign 28-1S, the STS ion-exchange columns were operated with straight Tank 8D-2 sludge wash supernatant.

The STS ion-exchange columns operated abnormally, producing low system decontamination factors that were indicative of improper operation. The overall weighted system Cs-137 DF for the campaign was 3,623. The system achieved a maximum DF for Cs-137 of 6,481.

As stated in the Summary Section, IRTS Campaign 28 operated with column C containing TIE-96 zeolite and columns B and A containing IE-96 zeolite. The average system DF for $\mathrm{Pu}$ was 42 . The DF for Pu was determined by laboratory analysis of the influent $\mathrm{Pu}$ concentration to the TIE- 96 column and dividing by the $\mathrm{Pu}$ concentration in Tank 8D-3. The DF of 42 is lower than expected for operation with one TIE-96 column. See Table 38 for campaign operational data.

\subsubsection{Comments and Observations}

As stated above, the DF for Cs-137 and the DF for Pu were lower than expected. Although the decontamination factors were low, no major problems were noted with the system. 
Table 38.

Campaign 28-1S

Detailed Table of Run Statistics

\begin{tabular}{|c|c|c|c|c|c|c|c|c|c|c|}
\hline Transfer Number & 1 & 2 & 3 & 4 & 5 & 6 & 7 & 8 & 9 & 10 \\
\hline Date & $3 / 19 / 94$ & $3 / 20 / 94$ & $3 / 22 / 94$ & $3 / 23 / 94$ & $3 / 28 / 94$ & $3 / 30 / 94$ & $3 / 31 / 94$ & $4 / 5 / 94$ & $4 / 6 / 94$ & $4 / 6 / 94$ \\
\hline STS Flowrate (gpm) & 6 & 6 & 6 & 6 & 6 & 6 & 6 & 6 & 6 & 6 \\
\hline D-001 Sample Number & 14 & 15 & 16 & 16 & 19 & 21 & 22 & 24 & 25 & 25 \\
\hline Cs-137 ( $\mu \mathrm{Ci} / \mathrm{ml})$ & $4.17 \mathrm{E}+2$ & $4.83 \mathrm{E}+2$ & $4.95 \mathrm{E}+2$ & $4.95 \mathrm{E}+2$ & $7.64 \mathrm{E}+2$ & $5.04 \mathrm{E}+2$ & $4.10 \mathrm{E}+2$ & $4.75 \mathrm{E}+2$ & $4.95 \mathrm{E}+2$ & $4.95 \mathrm{E}+2$ \\
\hline TDS $(w t \%)$ & 12.01 & 13.18 & 13.24 & 13.24 & 13.42 & 13.50 & 11.76 & 13.38 & 13.45 & 13.45 \\
\hline Density (g/ml) & 1.089 & 1.098 & 1.099 & 1.099 & 1.100 & 1.101 & 1.087 & 1.100 & 1.100 & 1.100 \\
\hline \multicolumn{11}{|l|}{ Cs-137 Activity } \\
\hline Lead Column B $(\mu \mathrm{Ci} / \mathrm{ml})$ & $3.77 \mathrm{E}+1$ & $5.15 \mathrm{E}+1$ & $6.60 \mathrm{E}+1$ & $9.17 \mathrm{E}+1$ & $1.47 \mathrm{E}+2$ & $1.58 \mathrm{E}+2$ & $2.22 \mathrm{E}+2$ & $1.98 \mathrm{E}+2$ & $2.34 \mathrm{E}+2$ & $4.04 \mathrm{E}+2$ \\
\hline 2nd Column $\mathrm{C}(\mu \mathrm{Ci} / \mathrm{ml})$ & $6.35 \mathrm{E}-1$ & $9.85 \mathrm{E}-1$ & $1.89 \mathrm{E}+0$ & $3.21 E+0$ & $4.29 \mathrm{E}+0$ & $1.02 \mathrm{E}+1$ & $1.75 \mathrm{E}+1$ & $.3 .87 \mathrm{E}+1$ & $3.14 \mathrm{E}+1$ & $3.37 \mathrm{E}+1$ \\
\hline \multicolumn{11}{|l|}{ Column Breakthrough } \\
\hline Lead Column B $(\%)$ & 9.0 & 10.66 & 13.3 & 18.5 & 29.2 & 31.3 & 54.1 & 41.7 & 47.3 & 81.6 \\
\hline 2nd Column C (\%) & 1.7 & 1.9 & 2.9 & 3.5 & 2.9 & 6.4 & 7.9 & 19.5 & 13.4 & 8.3 \\
\hline 8D-3 Sample Number & 8 & 9 & 10 & 11 & 12 & 13 & 14 & 16 & 17 & 18 \\
\hline $\mathrm{Cs}-137(\mu \mathrm{Ci} / \mathrm{ml})$ & $1.89 \mathrm{E}-1$ & $2.00 \mathrm{E}-1$ & $2.10 \mathrm{E}-1$ & $9.65 \mathrm{E}-2$ & $8.02 \mathrm{E}-2$ & $7.49 \mathrm{E}-2$ & $1.09 \mathrm{E}-1$ & $4.54 \mathrm{E}-2$ & $2.17 \mathrm{E}-1$ & $1.87 \mathrm{E}-1$ \\
\hline $\operatorname{TDS}(w t \%)$ & 10.72 & 12.74 & 13.24 & 13.30 & 7.64 & 13.05 & 13.50 & 5.62 & 11.94 & 9.86 \\
\hline Density $(\mathrm{g} / \mathrm{ml})$ & 1.079 & 1.095 & 1.099 & 1.099 & 1.055 & 1.097 & 1.101 & 1.040 & 1.088 & 1.072 \\
\hline \multicolumn{11}{|l|}{ STS System DF } \\
\hline Cs-137 DF & 1,951 & 2,328 & 2,357 & 5,129 & 5,201 & 6,481 & 4,605 & 4,145 & 2,003 & 1,891 \\
\hline alpha-Pu DF & 41 & 81 & 36 & 57 & 23 & 27 & 10 & 9.1 & 11 & 218 \\
\hline 5D-15B Sample Number & 8 & 9 & 10 & 11 & 12 & 13 & 14 & 15 & 16 & 17 \\
\hline $\mathrm{Cs}-137(\mu \mathrm{Ci} / \mathrm{ml})$ & $2.09 \mathrm{E}-1$ & $2.00 \mathrm{E}-1$ & $1.11 \mathrm{E}-1$ & $4.14 \mathrm{E}-2$ & $6.24 \mathrm{E}-2$ & $7.90 \mathrm{E}-2$ & $1.06 \mathrm{E}-1$ & $1.03 \mathrm{E}-1$ & $1.92 \mathrm{E}-1$ & $1.48 \mathrm{E}-1$ \\
\hline TDS $(w t \%)$ & 11.27 & 12.74 & 12.87 & 6.95 & 10.19 & 13.33 & 12.19 & 9.99 & 12.24 & 8.04 \\
\hline Density (g/ml) & 1.083 & 1.095 & 1.096 & 1.050 & 1.075 & 1.099 & 1.090 & 1.073 & 1.091 & 1.058 \\
\hline Volume in 5D-15B (liters) & 40,060 & 40,060 & 41,012 & 24,850 & 40,060 & 40,060 & 39,380 & 34,360 & 40,912 & 19,960 \\
\hline Cumulative Volume (liters) & 40,060 & 80,120 & 121,132 & 145,982 & 186,042 & 226,102 & 265,482 & 299,842 & 340,754 & 360,714 \\
\hline
\end{tabular}




\subsection{IRTS Campaign 29-1S-2S ${ }^{21}$}

\subsubsection{Summary}

IRTS Campaign 29-1S-2S began April 20, 1994 and ended July 21, 1994, after processing 227,983 gallons of Tank 8D-2 sludge wash supernatant from sludge wash 1 and sludge wash 2. During IRTS Campaign 29, treatment of sludge wash 1 was completed, and sludge wash 2 processing began on June 14, 1994.

The STS ion-exchange columns were operated in sequence $C, A, B$; with column $C$ as the lead column, column $\mathrm{A}$ as the second column, and column $\mathrm{B}$ as the final column. Columns $\mathrm{C}$ and $\mathrm{B}$ contained TIE-96 zeolite, column A contained IE-96 zeolite. The target dilution factor was one part water to two parts sludge wash supernatant by volume. The STS was operated in three cycles during IRTS Campaign 29-1S-2S. IRTS Campaign 29-1 S-2S sludge wash supernatant processing resulted in the removal of $61.4 \mathrm{kCi}$ of Cs-137 activity and 2.21 grams of fissile Pu from Tank $8 \mathrm{D}-2$ solution.

One column of zeolite with a volume of approximately 67 cubic feet and mass of $1293 \mathrm{~kg}$ was used during IRTS Campaign 29-1S-2S.

\subsubsection{Column Performance}

During Campaign 29-1S-2S, the STS ion-exchange columns were operated with straight Tank 8D-2 sludge wash supernatant.

The STS ion-exchange columns operated normally, producing high system decontamination factors indicative of proper operation. The overall weighted system Cs-137 DF for the campaign was 10,938. The system achieved a maximum DF for Cs-137 of 43,669 .

As stated in the Summary Section, IRTS Campaign 29 operated with column B containing TIE-96 zeolite and columns $\mathrm{C}$ and A containing IE-96 zeolite. The average system DF for Pu was 204. The DF for Pu was determined by laboratory analysis of the influent $\mathrm{Pu}$ concentration to the TIE- 96 column and dividing by the Pu concentration in Tank 8D-3. The DF of 204 is approximately the expected DF for operation with one TIE96 column. See Table 39 for campaign operational data.

\subsubsection{Comments and Observations}

The STS performed with no major problems during IRTS Campaign 29-1S-2S. 
Table 39.

Campaign 29 1-S and 2-S

Detailed Table of Run Statistics

\begin{tabular}{|c|c|c|c|c|c|c|c|}
\hline $\begin{array}{l}\text { Transfer Number } \\
\text { Date } \\
\text { STS Flowrate (gpm) }\end{array}$ & $\begin{array}{l}1 \\
4 / 20 / 94 \\
6\end{array}$ & $\begin{array}{l}2 \\
4 / 21 / 94 \\
6\end{array}$ & $\begin{array}{l}3 \\
4 / 22 / 94 \\
6\end{array}$ & $\begin{array}{l}4 \\
5 / 2 / 94 \\
6\end{array}$ & $\begin{array}{l}5 \\
5 / 3 / 94 \\
6\end{array}$ & $\begin{array}{l}6 \\
5 / 4 / 94 \\
6\end{array}$ & $\begin{array}{l}7 \\
5 / 5 / 94 \\
6\end{array}$ \\
\hline $\begin{array}{l}\text { D-001 Sample Number } \\
\mathrm{Cs}-137(\mu \mathrm{Ci} / \mathrm{ml}) \\
\text { TDS (wt }) \\
\text { Density }(\mathrm{g} / \mathrm{ml})\end{array}$ & $\begin{array}{l}27 \\
4.65 \mathrm{E}+2 \\
12.76 \\
1.095\end{array}$ & $\begin{array}{l}28 \\
4.64 \mathrm{E}+2 \\
12.76 \\
1.095\end{array}$ & $\begin{array}{l}28 \\
4.64 \mathrm{E}+2 \\
12.76 \\
1.095\end{array}$ & $\begin{array}{l}30 \\
4.00 \mathrm{E}+2 \\
11.20 \\
1.083\end{array}$ & $\begin{array}{l}31 \\
4.17 E+2 \\
12.16 \\
1.09\end{array}$ & $\begin{array}{l}32 \\
4.32 \mathrm{E}+2 \\
12.18 \\
1.090\end{array}$ & $\begin{array}{l}32 \\
4.32 \mathrm{E}+2 \\
12.18 \\
1.090\end{array}$ \\
\hline $\begin{array}{l}\text { Cs-137 Activity } \\
\text { Lead Column B }(\mu \mathrm{Ci} / \mathrm{ml}) \\
\text { 2nd Column } C(\mu \mathrm{Ci} / \mathrm{ml})\end{array}$ & $\begin{array}{l}4.28 \mathrm{E}+1 \\
3.17 \mathrm{E}-1\end{array}$ & $\begin{array}{l}5.89 E+1 \\
3.76 E-1\end{array}$ & $\begin{array}{l}6.46 \mathrm{E}+1 \\
5.79 \mathrm{E}-1\end{array}$ & $\begin{array}{l}6.80 \mathrm{E}+1 \\
6.37 \mathrm{E}-1\end{array}$ & $\begin{array}{l}8.60 \mathrm{E}+1 \\
9.05 \mathrm{E}-1\end{array}$ & $\begin{array}{l}1.05 E+2 \\
1.61 E+0\end{array}$ & $\begin{array}{l}1.27 \mathrm{E}+2 \\
2.40 \mathrm{E}+0\end{array}$ \\
\hline $\begin{array}{l}\text { Column Breakthrough } \\
\text { Lead Column B (8) } \\
\text { 2nd Column } C(z)\end{array}$ & $\begin{array}{l}9.2 \\
0.7\end{array}$ & $\begin{array}{l}12.7 \\
0.6\end{array}$ & $\begin{array}{l}13.9 \\
0.9\end{array}$ & $\begin{array}{l}17.0 \\
0.9\end{array}$ & $\begin{array}{l}20.6 \\
1.0\end{array}$ & $\begin{array}{l}24.3 \\
1.5\end{array}$ & $\begin{array}{l}29.4 \\
1.9\end{array}$ \\
\hline $\begin{array}{l}\text { 8D-3 Sample Number } \\
\text { Cs-137 ( } \mathrm{HCi} / \mathrm{ml}) \\
\text { TDS (wt }) \\
\text { Density }(\mathrm{g} / \mathrm{ml})\end{array}$ & $\begin{array}{l}19 \\
6.08 \mathrm{E}-2 \\
7.21 \\
1.052\end{array}$ & $\begin{array}{l}20 \\
2.67 \mathrm{E}-2 \\
12.15 \\
1.090\end{array}$ & $\begin{array}{l}21 \\
6.96 \mathrm{E}-3 \\
4.30 \\
1.030\end{array}$ & $\begin{array}{l}22 \\
\frac{1}{6}: 44 E-2 \\
1.046\end{array}$ & $\begin{array}{l}23 \\
9.10 E-3 \\
11.63 \\
1.086\end{array}$ & $\begin{array}{l}24 \\
9.86 \mathrm{E}-3 \\
12.14 \\
1.090\end{array}$ & $\begin{array}{l}25 \\
1.14 \mathrm{E}-2 \\
9.81 \\
1.072\end{array}$ \\
\hline $\begin{array}{l}\text { STS Syster DF } \\
\text { Cs-137 DF } \\
\text { alpha-Pu DF }\end{array}$ & $\begin{array}{l}4,152 \\
41\end{array}$ & $\begin{array}{l}16,472 \\
241\end{array}$ & $\begin{array}{l}20,641 \\
439\end{array}$ & $\begin{array}{l}15,379 \\
105\end{array}$ & $\begin{array}{l}43,666 \\
357\end{array}$ & $\begin{array}{l}43,669 \\
260\end{array}$ & $\begin{array}{l}30,017 \\
457\end{array}$ \\
\hline $\begin{array}{l}\text { 5D-15B Sample Number } \\
\mathrm{Cs}-137 \text { (pCi/ml) } \\
\text { TDS (wt8) } \\
\text { Density }(\mathrm{g} / \mathrm{ml})\end{array}$ & $\begin{array}{l}18 \\
4.81 \mathrm{E}-2 \\
9.48 \\
1.069\end{array}$ & $\begin{array}{l}19 \\
2.05 \mathrm{E}-2 \\
11.00 \\
1.081\end{array}$ & $\begin{array}{l}20 \\
1.47 E-2 \\
8.40 \\
1.061\end{array}$ & $\begin{array}{l}22 \\
3.02 \mathrm{E}-2 \\
10.26 \\
1.075\end{array}$ & $\begin{array}{l}23 \\
8.27 \mathrm{E}-3 \\
11.78 \\
1.087\end{array}$ & $\begin{array}{l}24 \\
1.12 \mathrm{E}-2 \\
11.81 \\
1.087\end{array}$ & $\begin{array}{l}25 \\
7.50 \mathrm{E}-3 \\
7.56 \\
1.055\end{array}$ \\
\hline $\begin{array}{l}\text { Volume in 5D-15B } \\
\text { (liters) } \\
\text { Cumulative volume } \\
\text { (1iters) }\end{array}$ & $\begin{array}{l}40,730 \\
40,730\end{array}$ & $\begin{array}{l}35,140 \\
75,870\end{array}$ & $\begin{array}{l}6,270 \\
82,140\end{array}$ & $\begin{array}{l}40,653 \\
122,793\end{array}$ & $\begin{array}{l}40,060 \\
162,853\end{array}$ & $\begin{array}{l}36,953 \\
199,806\end{array}$ & $\begin{array}{l}10,280 \\
210,086\end{array}$ \\
\hline
\end{tabular}


Table 39. (continued)

Campaign 29 1-S and 2-S

Detailed Table of Run Statistics

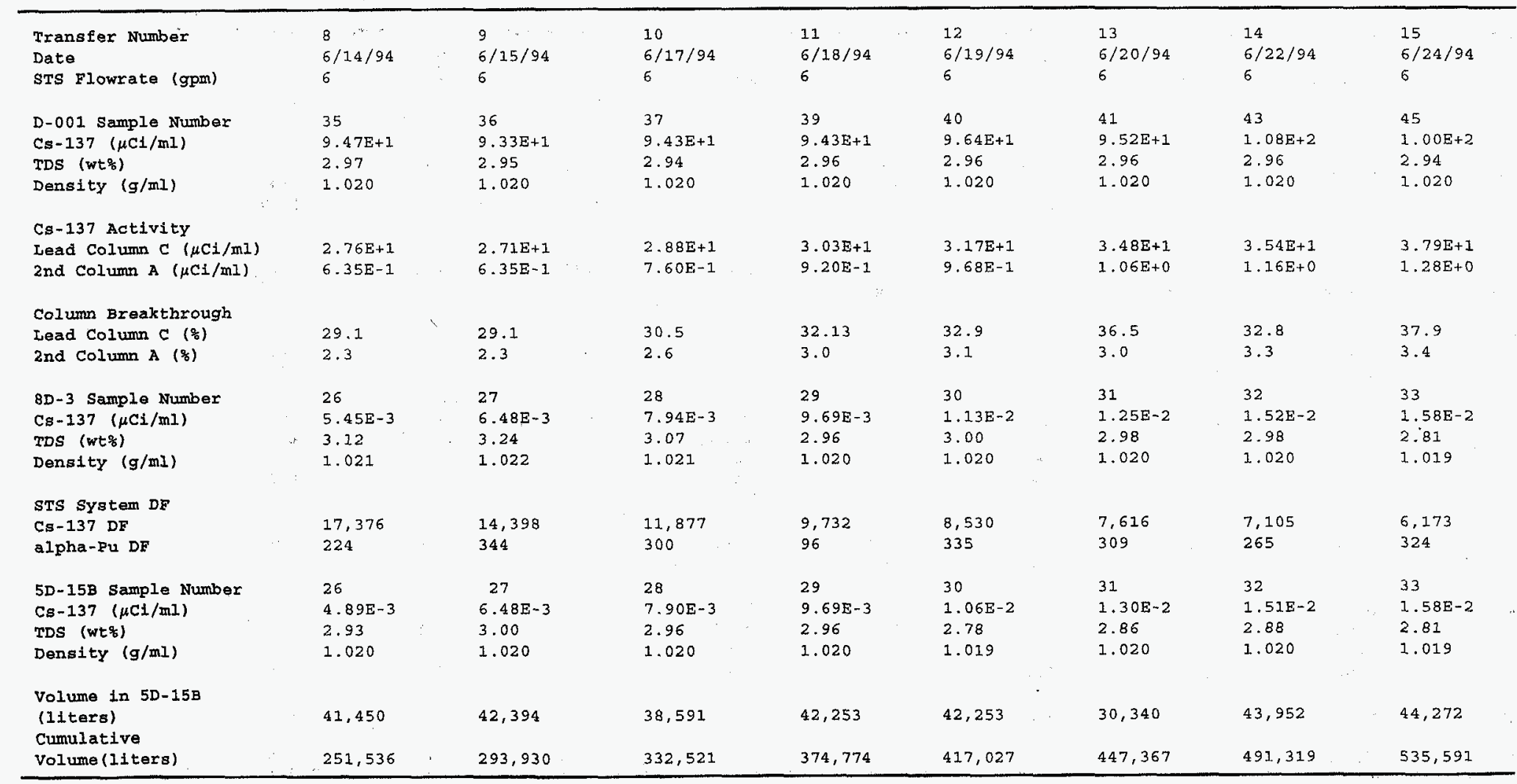


Table 39. (continued)

Campaign $291-\mathrm{S}$ and 2-S

Detailed Table of Run Statistics

\begin{tabular}{|c|c|c|c|c|c|c|c|c|}
\hline $\begin{array}{l}\text { Transfer Number } \\
\text { Date } \\
\text { STS Flowrate (gpm) }\end{array}$ & $\begin{array}{l}16 \\
6 / 25 / 94 \\
6\end{array}$ & $\begin{array}{l}17 \\
6 / 27 / 94 \\
6\end{array}$ & $\begin{array}{l}18 \\
6 / 28 / 94 \\
6\end{array}$ & $\begin{array}{l}19 \\
6 / 29 / 94 \\
6\end{array}$ & $\begin{array}{l}20 \\
6 / 30 / 94 \\
6\end{array}$ & $\begin{array}{l}21 \\
7 / 1 / 94 \\
6\end{array}$ & $\begin{array}{l}22 \\
7 / 6 / 94 \\
6\end{array}$ & $\begin{array}{l}23 \\
7 / 7 / 94 \\
6\end{array}$ \\
\hline $\begin{array}{l}\text { D-001 Sample Number } \\
\text { Css137 }(\mu \mathrm{Ci} / \mathrm{ml}) \\
\text { TDS }(w t \%) \\
\text { Density }(\mathrm{g} / \mathrm{ml})\end{array}$ & $\begin{array}{l}46 \\
9.44 \mathrm{E}+1 \\
2.95 \\
1.020\end{array}$ & $\begin{array}{l}47 \\
8.87 \mathrm{E}+1 \\
3.00 \\
1.020\end{array}$ & $\begin{array}{l}49 \\
9.27 \mathrm{E}+1 \\
2.88 \\
1.020\end{array}$ & $\begin{array}{l}50 \\
9.38 \mathrm{E}+1 \\
2.93 \\
1.020\end{array}$ & $\begin{array}{l}51 \\
9.31 \mathrm{E}+1 \\
2.96 \\
1.020\end{array}$ & $\begin{array}{l}52 \\
9.10 \mathrm{E}+1 \\
2.98 \\
1.020\end{array}$ & $\begin{array}{l}56 \\
9.56 \mathrm{E}+1 \\
2.96 \\
1.020\end{array}$ & $\begin{array}{l}56 \\
9.56 \mathrm{E}+1 \\
2.96 \\
1.020\end{array}$ \\
\hline $\begin{array}{l}\text { Cs-137 Activity } \\
\text { Lead Column C }(\mu \mathrm{Ci} / \mathrm{ml}) \\
\text { 2nd Column A }(\mu \mathrm{Ci} / \mathrm{ml})\end{array}$ & $\begin{array}{l}4.03 \mathrm{E}+1 \\
1.56 \mathrm{E}+0\end{array}$ & $\begin{array}{l}4.20 \mathrm{E}+1 \\
1.63 \mathrm{E}+0\end{array}$ & $\begin{array}{l}3.87 \mathrm{E}+1 \\
1.77 \mathrm{E}+0\end{array}$ & $\begin{array}{l}4.38 \mathrm{E}+1 \\
1.80 \mathrm{E}+0\end{array}$ & $\begin{array}{l}4.59 \mathrm{E}+1 \\
2.08 \mathrm{E}+0\end{array}$ & $\begin{array}{l}4.79 \mathrm{E}+1 \\
2.22 \mathrm{E}+0\end{array}$ & $\begin{array}{l}5.48 \mathrm{E}+1 \\
2.62 \mathrm{E}+0\end{array}$ & $\begin{array}{l}5.15 \mathrm{E}+1 \\
2.73 \mathrm{E}+0\end{array}$ \\
\hline $\begin{array}{l}\text { Column Breakthrough } \\
\text { Lead Column } C(\%) \\
\text { 2nd Column A }(\%)\end{array}$ & $\begin{array}{l}42.7 \\
3.9\end{array}$ & $\begin{array}{l}47.3 \\
3.9\end{array}$ & $\begin{array}{l}41.8 \\
4.6\end{array}$ & $\begin{array}{l}46.7 \\
4.1\end{array}$ & $\begin{array}{l}49.3 \\
4.5\end{array}$ & $\begin{array}{l}52.6 \\
4.6\end{array}$ & $\begin{array}{l}57.3 \\
4.8\end{array}$ & $\begin{array}{l}53.9 \\
5.3\end{array}$ \\
\hline $\begin{array}{l}\text { 8D-3 Sample Number } \\
\text { Cs-137 }(\mu \mathrm{Ci} / \mathrm{ml}) \\
\text { TDS }(w t \%) \\
\text { Density }(g / \mathrm{ml})\end{array}$ & $\begin{array}{l}34 \\
2.00 \mathrm{E}-2 \\
2.96 \\
1.020\end{array}$ & $\begin{array}{l}35 \\
2.42 \mathrm{E}-2 \\
3.00 \\
1.020\end{array}$ & $\begin{array}{l}36 \\
2.64 \mathrm{E}-2 \\
2.96 \\
1.020\end{array}$ & $\begin{array}{l}37 \\
3.09 \mathrm{E}-2 \\
2.95 \\
1.020\end{array}$ & $\begin{array}{l}38 \\
3.64 \mathrm{E}-2 \\
2.96 \\
1.020\end{array}$ & $\begin{array}{l}39 \\
2.94 \mathrm{E}-2 \\
2.21 \\
1.019\end{array}$ & $\begin{array}{l}40 \\
4.12 \mathrm{E}-2 \\
2.78 \\
1.019\end{array}$ & $\begin{array}{l}41 \\
4.59 \mathrm{E}-2 \\
2.93 \\
1.020\end{array}$ \\
\hline $\begin{array}{l}\text { STS System DF } \\
\text { Cs-137 DF } \\
\text { Alpha Pu DF }\end{array}$ & $\begin{array}{l}4,720 \\
235\end{array}$ & $\begin{array}{l}3,665 \\
234\end{array}$ & $\begin{array}{l}3,511 \\
341\end{array}$ & $\begin{array}{l}3,036 \\
417\end{array}$ & $\begin{array}{l}2,558 \\
302\end{array}$ & $\begin{array}{l}3,095 \\
228\end{array}$ & $\begin{array}{l}2,320 \\
138\end{array}$ & $\begin{array}{l}2,083 \\
208\end{array}$ \\
\hline $\begin{array}{l}\text { 5D-15B Sample Number } \\
\text { Cs-137 }(\mu \mathrm{Ci} / \mathrm{ml}) \\
\text { TDS }(w \mathrm{t} \%) \\
\text { Density }(\mathrm{g} / \mathrm{ml})\end{array}$ & $\begin{array}{l}34 \\
2.06 \mathrm{E}-2 \\
2.86 \\
1.019\end{array}$ & $\begin{array}{l}35 \\
2.05 \mathrm{E}-2 \\
2.77 \\
1.019\end{array}$ & $\begin{array}{l}36 \\
2.58 \mathrm{E}-2 \\
2.89 \\
1.019\end{array}$ & $\begin{array}{l}37 \\
3.00 \mathrm{E}-2 \\
2.83 \\
1.019\end{array}$ & $\begin{array}{l}38 \\
3.40 \mathrm{E}-2 \\
2.78 \\
1.019\end{array}$ & $\begin{array}{l}39 \\
2.72 \mathrm{E}-2 \\
1.98 \\
1.013\end{array}$ & $\begin{array}{l}40 \\
3.09 \mathrm{E}-2 \\
2.64 \\
1.018\end{array}$ & $\begin{array}{l}41 \\
4.23 \mathrm{E}-2 \\
2.71 \\
1.018\end{array}$ \\
\hline Volume in 5D-15B (liters) & 42,890 & 44,370 & 42,253 & 43,532 & 43,178 & 42,120 & 42,893 & 43,379 \\
\hline Cumulative Volume (liters) & 578,481 & 622,851 & 665,104 & 708,636 & 751,814 & 793,934 & 836,827 & 880,206 \\
\hline
\end{tabular}




\subsection{IRTS Campaign 30-2S-3S}

\subsubsection{Summary}

IRTS Campaign 30-2S-3S began July 22, 1994 and ended February 24, 1995, after processing 240,398 gallons of Tank 8D-2 sludge wash supernatant from sludge wash two and the THOREX wash. During IRTS Campaign 30, treatment of sludge wash two was completed on August 19, 1994 and THOREX wash processing began on January 31,1995 . The idle process time period between sludge wash two and the THOREX processing was used to install and modify equipment required for the eventual THOREX transfer from Tank 8D-4 to Tank 8D-2.

columns. The STS was operated in five cycles during IRTS Campaign 30-1S-2S. IRTS Campaign 30-2S-3S sludge wash supernatant processing resulted in the removal of $134.5 \mathrm{kCi}$ of Cs-137 activity and 0.98 grams of fissile Pu from Tank 8D-2 solution.

One column of zeolite with a volume of approximately 67 cubic feet and mass of $1,293 \mathrm{~kg}$ was used during IRTS Campaign 30-2S-3S.

\subsubsection{Column Performance}

During Campaign 30-2S-3S, the STS ion-exchange columns were operated with straight Tank 8D-2 sludge wash supernatant.

The STS ion-exchange columns operated normally, producing high system decontamination factors indicative of proper operation. The overall weighted system Cs-137 DF for the campaign was 8,568. The system achieved a maximum DF for Cs-137 of 23,568.

As stated in the Summary Section, IRTS Campaign 30-2S-3S operated with column B containing TIE-96 zeolite and columns $A$ and $C$ containing IE- 96 zeolite. The average system DF for $\mathrm{Pu}$ was 42 , with a maximum DF of 88 . The DF for Pu was determined by laboratory analysis of the influent Pu concentration to the TIE-96 column and dividing by the Pu concentration in Tank 8D-3. The DF of 42 is approximately the expected DF for operation with one TIE- 96 column. See Table 40 for campaign operational data.

\subsubsection{Comments and Observations}

The STS performed with no major problems during IRTS Campaign 30-2S-3S. See Table 40 for campaign operational data. 


\subsection{IRTS Campaign 31-3S}

\subsubsection{Summary}

IRTS Campaign 31-3S began March 5, 1995 and ended May 4, 1995, after processing 240,897 gallons of Tank 8D-2 THOREX wash supernatant. During IRTS Campaign 31, treatment of the THOREX Wash processing was completed.

The STS ion-exchange columns were operated in sequence $B, C, A$; with column $B$ as the lead column, column $\mathrm{C}$ as the second column, and column $\mathrm{A}$ as the final column. Columns $\mathrm{B}$ and $\mathrm{A}$ contained TIE-96 zeolite, column C contained IE-96 zeolite. There was no dilution of the THOREX wash solution feed to the STS columns. The STS was operated in three cycles during IRTS Campaign 31-3S. IRTS Campaign 31-3S sludge wash supernatant processing resulted in the removal of $226.1 \mathrm{kCi}$ of Cs-137 activity and 1.82 grams of fissile Pu from Tank 8D-2 solution.

One column of zeolite with a volume of approximately 67 cubic feet and mass of $1293 \mathrm{~kg}$ was used during IRTS Campaign 31-3S.

\subsubsection{Column Performance}

During Campaign 31-3S, the STS ion-exchange columns were operated with straight Tank 8D-2 THOREX wash supernatant.

The STS ion-exchange columns operated normally, producing high system decontamination factors indicative of proper operation. The overall weighted system Cs-137 DF for the campaign was 40,363 . The system achieved a maximum DF for Cs-137 of 126,178 .

As stated in the Summary Section, IRTS Campaign 31 operated with columns B and A containing TIE-96 zeolite and column C containing IE-96 zeolite. The average system DF for Pu was 71, with a maximum DF of 154. The DF for Pu was determined by laboratory analysis of the influent Pu concentration to the TIE- 96 column and dividing by the Pu concentration in Tank 8D-3. The DF of 71 is approximately the expected DF for operation with two TIE-96 columns. See Table 41 for campaign operational data.

\subsubsection{Comments and Observations}

The STS performed with no major problems during IRTS Campaign 31-3S. 
Table 40 .

Campaign $30-2 \mathrm{~S}$ and $3 \mathrm{~S}$

Detailed Table of Run Statistics

Transfer Number

STS Flow Rate (gpm)

D-001 Sample Number

$\mathrm{Cs}-137(\mu \mathrm{Ci} / \mathrm{mL})$

TDS (wt \%)

Density ( $\mathrm{g} / \mathrm{mL}$ )

Cs-137 Activity

Lead Column A

$(\mu \mathrm{Ci} / \mathrm{mL})$

2nd Column B

N

( $\mu \mathrm{Ci} / \mathrm{mL})$

Column Breakthrough

Lead Column A $(\%)$

2nd Column B (\%)

8D-3 Sample Number

Cs-137 ( $\mu \mathrm{Ci} / \mathrm{mL})$

TDS (wt\%)

Density ( $g / m L)$

STS System DF

Cesium 137 DF

Alpha Plutonium DF

5D-15B Sample Number

Cs-137 ( $\mu \mathrm{Ci} / \mathrm{mL})$

TDS (wt\%)

Density ( $g / \mathrm{mL}$ )

Volume Received in 5D-15B (liters)

Cumulative Volume (liters)

\begin{tabular}{ll}
1 & \multicolumn{1}{c}{2} \\
$7 / 26 / 94$ & $7 / 28 / 94$ \\
6 & 6 \\
& 6 \\
59 & 60 \\
$9.15 \mathrm{E}+01$ & $9.28 \mathrm{E}+01$ \\
4.60 & -- \\
1.019 & 1.020
\end{tabular}

\begin{tabular}{l}
3 \\
$7 / 29 / 94$ \\
6 \\
61 \\
$8.92 \mathrm{E}+01$ \\
\hdashline .020
\end{tabular}

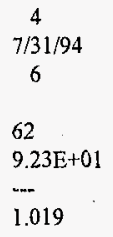

5
$8 / 01 / 94$
6
64
$9.27 \mathrm{E}+01$
.-
1.020

6
$8 / 03 / 94$
6

65
$9.13 \mathrm{E}+01$
2.89
1.020

7
$8 / 06 / 94$
6

8
$8 / 07 / 9$

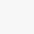

68

$8.97 \mathrm{E}+01$

2.86
1.019

6

69

$9.53 \mathrm{E}+01$

1.020

\begin{tabular}{|c|c|c|c|c|c|c|c|}
\hline $2.72 E+00$ & $2.73 \mathrm{E}+00$ & $3.36 \mathrm{E}+00$ & $3.60 \mathrm{E}+00$ & $4.18 \mathrm{E}+00$ & $4.43 \mathrm{E}+00$ & $4.76 \mathrm{E}+00$ & $4.56 \mathrm{E}+00$ \\
\hline $1.11 E-01$ & $8.02 \mathrm{E}-01$ & $7.11 \mathrm{E}-02$ & $8.28 \mathrm{E}-02$ & $9.86 \mathrm{E}-02$ & $1.15 \mathrm{E}-01$ & $9.16 \mathrm{E}-02$ & $1.08 \mathrm{E}-01$ \\
\hline 2.97 & 2.94 & 3.77 & 3.90 & 4.51 & 4.85 & 5.31 & 4.78 \\
\hline 4.08 & 2.94 & 2.12 & 2.30 & 2.36 & 2.60 & 1.92 & 2.37 \\
\hline 10 & 11 & 12 & 13 & 14 & & 16 & 17 \\
\hline $6.00 \mathrm{E}-02$ & $2.05 \mathrm{E}-02$ & $1.11 \mathrm{E}-02$ & $7.86 \mathrm{E}-3$ & $6.31 \mathrm{E}-03$ & $5.58 \mathrm{E}-03$ & $4.12 \mathrm{E}-03$ & $4.53 \mathrm{E}-03$ \\
\hline 3.08 & 5.17 & 5.42 & 5.45 & 5.47 & 5.48 & 3375 & 6.13 \\
\hline 1.038 &..- & 1.035 & --- & $\cdots$ & --- & 1.023 & 1.040 \\
\hline
\end{tabular}

5,055

12,308

11,220

11,509

11,448

54

11,572
46

11,944
51

${ }_{53}^{11,404}$

42.43

$1.43-02$

2.15

43
$8.81 \mathrm{E}-03$

$8.81 \mathrm{E}-13$
2.64
1.018

44

$7.32 \mathrm{E}-03$

2.77

$\begin{array}{ll}46 & 47 \\ 7.81 \mathrm{E}-03 & 7.50 \mathrm{E}-03\end{array}$

$\begin{array}{ll}2.81 & 2.79\end{array}$

2.79
1.019

$5.56 \mathrm{E}-03$

2.09

2.09
I. 014

49
$7.65 \mathrm{E}-03$

2.64

$\begin{array}{ll}2.79 & 2.81 \\ 1.019 & 1019\end{array}$

41,306

43,403

40,435

42,710

209,307

252,709

293,144

335,854 
Table 40

Campaign 30-2S and 3S (continued)

Detailed Table of Run Statistics

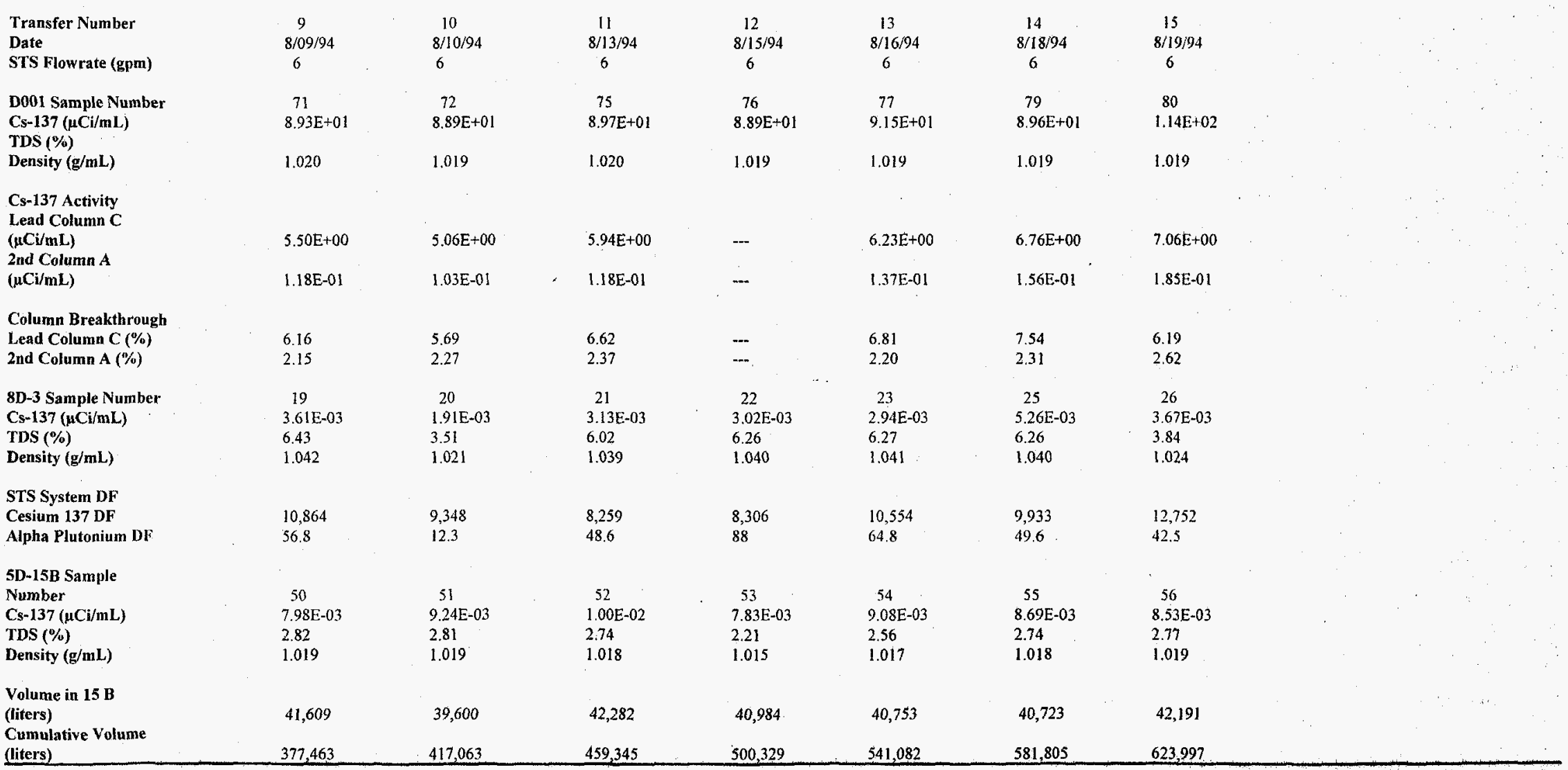


Table 40 .

Campaign $30-2 \mathrm{~S}$ and $3 \mathrm{~S}$ (continued)

Detailed Table of Run Statistics

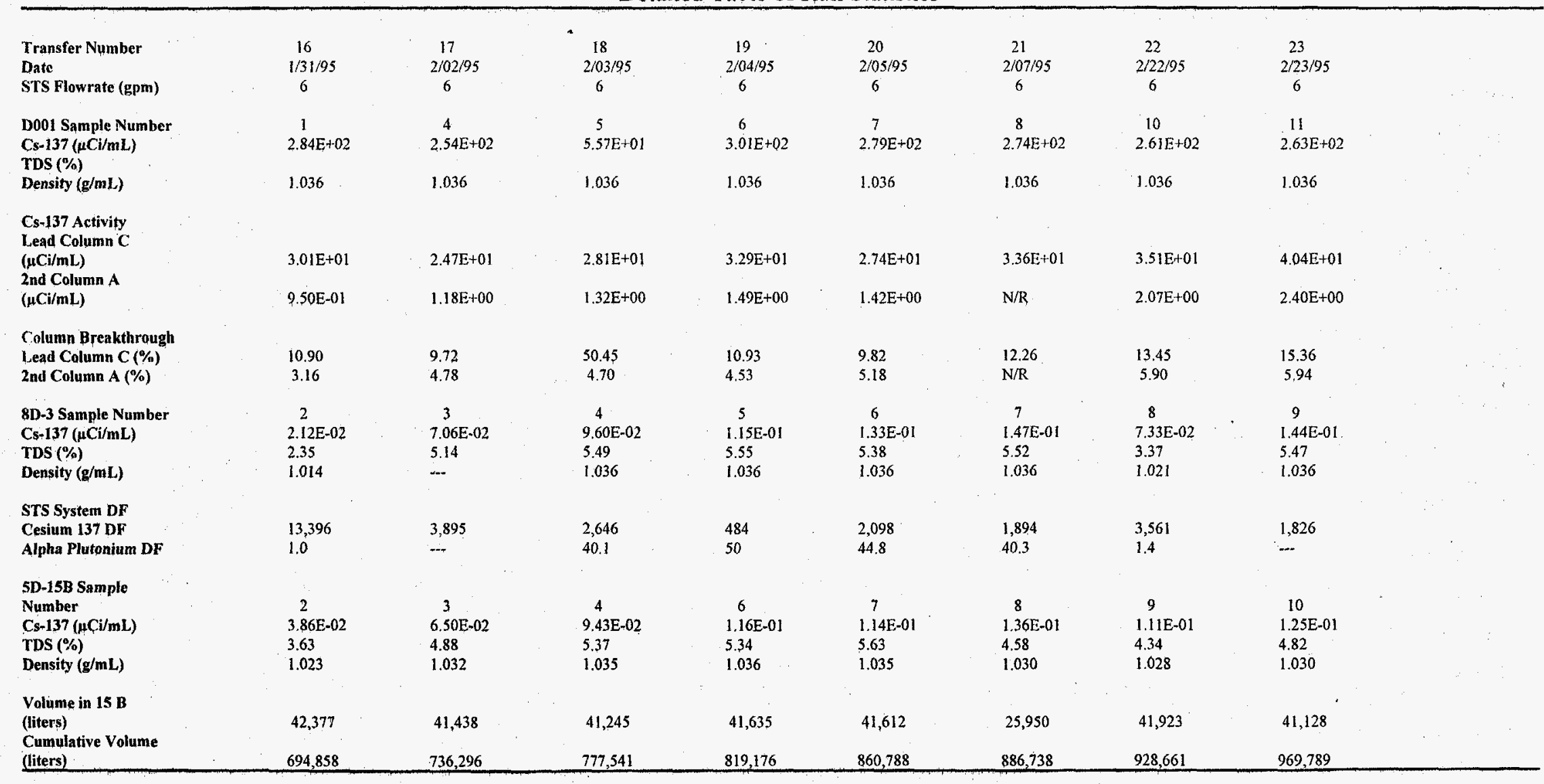


Table 41.

Campaign 31-3S

Detailed Table of Run Statistics

\begin{tabular}{|c|c|c|c|c|c|c|c|c|c|}
\hline Transfer Number & 1 & 2 & 3 & 4 & 5 & 6 & 7 & 8 & 9 \\
\hline Date & $3 / 08 / 95$ & $3 / 09 / 95$ & $3 / 10 / 95$ & $3 / 12 / 95$ & $3 / 13 / 95$ & $3 / 14 / 95$ & $3 / 21 / 95$ & $3 / 22 / 95$ & $3 / 23 / 95$ \\
\hline STS Flow Rate (gpm) & 5 & 5 & 4 & 4 & 5 & 5 & 6 & 5 & 6 \\
\hline D-001 Sample Number & 16 & 17 & 18 & 19 & 20 & 21 & 22 & 24 & 25 \\
\hline $\mathrm{Cs}-137(\mu \mathrm{Ci} / \mathrm{mL})$ & $2.15 \mathrm{E}+02$ & $2.76 \mathrm{E}+02$ & $3.16 \mathrm{E}+02$ & $2.71 \mathrm{E}+02$ & $2.70 \mathrm{E}+02$ & $2.65 E+02$ & $3.08 \mathrm{E}+02$ & $2.26 \mathrm{E}+02$ & $2.29 \mathrm{E}+02$ \\
\hline $\operatorname{TDS}(w t \%)$ & 4.60 & $\ldots$ & --- & $\ldots$ & $\ldots$ & $\ldots$ & 3.75 & 6.38 & 6.34 \\
\hline Density $(g / m L)$ & 1.029 & 1.035 & 1.035 & 1.035 & 1.035 & 1.035 & 1.023 & 1.041 & 1.041 \\
\hline \multicolumn{10}{|l|}{ Cs-137 Activity } \\
\hline$(\mu \mathrm{Ci} / \mathrm{mL})$ & $2.24 \mathrm{E}+00$ & $2.49 \mathrm{E}+00$ & $2.76 \mathrm{E}+00$ & $3.56 \mathrm{E}+00$ & $3.56 \mathrm{E}+00$ & $3.82 \mathrm{E}+00$ & $4.21 \mathrm{E}+00$ & $2.45 \mathrm{E}-01$ & $6.28 \mathrm{E}+00$ \\
\hline $\begin{array}{l}\text { 2nd Column } \mathrm{C} \\
(\mu \mathrm{Ci} / \mathrm{mL})\end{array}$ & $1.92 \mathrm{E}-01$ & $2.45 E-01$ & $2.28 \mathrm{E}-01$ & $2.39 \mathrm{E}-01$ & $1.92 \mathrm{E}-01$ & $1.94 \mathrm{E}-01$ & $2.09 \mathrm{E}-01$ & $2.60 \mathrm{E}-03$ & $2.94 \mathrm{E}-01$ \\
\hline \multicolumn{10}{|l|}{ Column Breakthrough } \\
\hline $\begin{array}{l}\text { Lead Column B (\%) } \\
\text { 2nd Column C (\%) }\end{array}$ & 1.04 & 0.90 & 0.87 & 1.15 & 1.32 & 1.44 & 1.37 & 0.11 & 2,74 \\
\hline 2nd Column C (\%) & 8.57 & 9.84 & 8.26 & 7.66 & 5.39 & 5.08 & 4.96 & 1.06 & 4.68 \\
\hline 8D-3 Sample Number & 10 & 11 & 12 & 13 & 14 & 15 & 16 & 17 & 18 \\
\hline Cs-137 $(\mu \mathrm{Ci} / \mathrm{mL})$ & $6.00 \mathrm{E}-02$ & $2.05 \mathrm{E}-02$ & $111 \mathrm{E}-02$ & $7.86 \mathrm{E}-3$ & $6.31 \mathrm{E}-03$ & $5.58 \mathrm{E}-03$ & $4.12 \mathrm{E}-03$ & $4.53 \mathrm{E}-03$ & $3.65 \mathrm{E}-03$ \\
\hline $\operatorname{TDS}(w t \%)$ & 3.08 & 5.17 & 5.42 & 5.45 & 5.47 & 5.48 & 3.75 & 6.13 & 6.37 \\
\hline Density $(\mathrm{g} / \mathrm{mL})$ & 1.038 & 1.033 & 1.035 & 1.035 & 1.035 & 1.035 & 1.023 & 1.040 & 1.041 \\
\hline \multicolumn{10}{|l|}{ STS System DF } \\
\hline Cesium $137 \mathrm{DF}$ & 3,583 & 13,463 & 28,468 & 34,351 & 41,997 & 55,197 & 54,874 & 50,552 & 63,288 \\
\hline Alpha Plutonium DF & 41.7 & 36.3 & 54 & 41.3 & 58.5 & 144.6 & 147.4 & 69.0 & 49.5 \\
\hline 5D-15B Sample Number & 11 & 12 & 13 & 14 & 15 & 16 & 17 & 18 & 19 \\
\hline $\mathrm{Cs}-137(\mu \mathrm{Ci} / \mathrm{mL})$ & $6.28-02$ & $2.18 \mathrm{E}-02$ & $1.14 \mathrm{E}-02$ & $7.31 \mathrm{E}-03$ & $5.46 \mathrm{E}-03$ & 4.12E-03 & $4.24 \mathrm{E}-03$ & $3.99 \mathrm{E}-0.3$ & $3,59 \mathrm{E}-0.3$ \\
\hline $\operatorname{TDS}(w t \%)$ & 4.10 & 4.98 & 5.28 & 5.32 & 5.34 & 4.75 & 4.68 & 5.92 & 6.33 \\
\hline Density ( $g / m L)$ & 1.025 & 1.032 & 1.034 & 1.034 & 1.034 & 1.030 & 1.029 & 1.038 & 1.041 \\
\hline $\begin{array}{l}\text { Volume Received in 5D-15B } \\
\text { (liters) }\end{array}$ & 36,680 & 41,979 & 42,176 & 40,424 & 41,544 & 30,810 & 42,434 & 41,151 & 31,188 \\
\hline Cumulative Volume (liters) & 36,680 & 78,660 & 120,836 & 161,260 & 202,804 & 233,614 & 276,048 & 317,198 & 348,387 \\
\hline
\end{tabular}


Table 41.

Campaign 31-3S (continued)

Detailed Table of Run Statistics

\begin{tabular}{|c|c|c|c|c|c|c|c|c|c|}
\hline Transfer Number & 10 & 11 & 12 & 13 & 14 & 15 & 16 & 17 & 18 \\
\hline Date & $3 / 24 / 95$ & $4 / 02 / 95$ & $4 / 03 / 95$ & $4 / 05 / 95$ & $4 / 06 / 95$ & $4 / 07 / 95$ & $4 / 08 / 95$ & $4 / 20 / 95$ & $4 / 21 / 95$ \\
\hline STS Flowrate (gpm) & 6 & 6 & 6 & 6 & 6 & 6 & 6 & 7 & 7 \\
\hline D001 Sample Number & 27 & 30 & 31 & 33 & 34 & Recirculation & 37 & 38 & \\
\hline $\mathrm{Cs}-137(\mu \mathrm{Ci} / \mathrm{mL})$ & $2.37 \mathrm{E}+02$ & $2.41 E+02$ & $2.45 E+02$ & $2.35 \mathrm{E}+02$ & $2.43 E+02$ & $\cdots$ & -.- & $2.49 E+02$ & $2.33 E+02$ \\
\hline $\operatorname{TDS}(\%)$ & 6.40 & -.- & $\cdots$ & $\cdots$ & -- & $\cdots$ & -- & $\ldots$ & --- \\
\hline Density $(\mathrm{g} / \mathrm{mL})$ & 1.042 & ... & 1.041 & 1.042 & 1.041 & -- & -- & 1.041 & 1.040 \\
\hline \multicolumn{10}{|l|}{ Cs-137 Activity } \\
\hline$(\mu \mathrm{Ci} / \mathrm{mL})$ & $7.95 \mathrm{E}+00$ & $9.58 \mathrm{E}+00$ & $1.16 \mathrm{E}+01$ & $1.35 \mathrm{E}+01$ & $1.64 \mathrm{E}+01$ & -.. & $\cdots$ & $3.87 \mathrm{E}+01$ & $5.37 \mathrm{E}+01$ \\
\hline $\begin{array}{l}\text { 2nd Column } C \\
(\mu \mathrm{Ci} / \mathrm{mL})\end{array}$ & $2.89 \mathrm{E}-01$ & $3.21 \mathrm{E}-01$ & $2.36 \mathrm{E}-01$ & $3.90 \mathrm{E}-01$ & $3.94 \mathrm{E}-01$ & $\ldots$ & -- & $5.07 \mathrm{E}-01$ & $4.50 \mathrm{E}-01$ \\
\hline \multicolumn{10}{|l|}{ Column Breakthrough } \\
\hline Lead Column B (\%) & 3.08 & 3.35 & 3.98 & 4.73 & 5.51 & --. & --. & 15.54 & 23.05 \\
\hline 2nd Column C (\%) & 4.29 & 3.64 & 3.35 & 2.03 & 2.89 & $\cdots$ & $\cdots$ & 1.31 & 0.84 \\
\hline 8D-3 Sample Number & 19 & 20 & 21 & 22 & 23 & - & -- & 26 & 27 \\
\hline $\mathrm{Cs}-137(\mu \mathrm{Ci} / \mathrm{mL})$ & $3.61 \mathrm{E}-03$ & $1.91 \mathrm{E}-03$ & $3.12 \mathrm{E}-03$ & $3.02 \mathrm{E}-03$ & $2.94 \mathrm{E}-03$ & $\cdots$ & -- & $3.67 \mathrm{E}-03$ & $9.99 \mathrm{E}-03$ \\
\hline $\operatorname{TDS}(\%)$ & 6.43 & 3.51 & 6.02 & 6.26 & 6.27 & -- & -- & 3.84 & 6.02 \\
\hline Density ( $(\mathrm{g} / \mathrm{mL})$ & 1.042 & 1.021 & 1.039 & 1.040 & 1.041 & $\cdots$ & - & 1.024 & 1.039 \\
\hline \multicolumn{4}{|l|}{ STS System DF } & & 79,932 & 46,197 & 67,847 & 24,925 & 14,430 \\
\hline Alpha Plutonium DF & 161.0 & 76.7 & 60.7 & 70.6 & 78.1 & 70.6 & 80.1 & 64.1 & 55.1 \\
\hline \multicolumn{9}{|l|}{ 5D-15B Sample } & 28 \\
\hline Cs-137 $(\mu \mathrm{C} \mathrm{j} / \mathrm{mL})$ & $2.69 \mathrm{E}-03$ & $2.36 \mathrm{E}-03$ & $2.67 \mathrm{E}-03$ & $2.87 \mathrm{E}-03$ & $3.2 \mathrm{IE}-03$ & 4.05E- -03 & $4.42 \mathrm{E}-03$ & $5.51 \mathrm{E}-03$ & $1.04 \mathrm{E}-02$ \\
\hline $\operatorname{TDS}(\%)$ & 5.76 & 4.73 & 5.90 & 6.20 & 6.19 & 6.12 & 4.93 & 4.81 & 5.81 \\
\hline Density $(\mathrm{g} / \mathrm{mL})$ & 1.037 & 1.030 & 1.038 & 1.040 & 1.040 & 1.040 & 1.031 & 1.030 & 1.037 \\
\hline Volume in $15 \mathrm{~B}$ & 42,642 & 39,004 & 41,385 & 42,377 & 42,225 & 40,235 & 10,235 & 44,795 & 40,424 \\
\hline $\begin{array}{l}\text { Cumulative Volume } \\
\text { (liters) }\end{array}$ & 391,028 & 430,033 & 471,418 & 513,795 & 556,020 & 596,254 & 606,489 & 651,284 & 691,708 \\
\hline
\end{tabular}


Table 41.

Campaign 31-3S (continued)

Detailed Table of Run Statistics

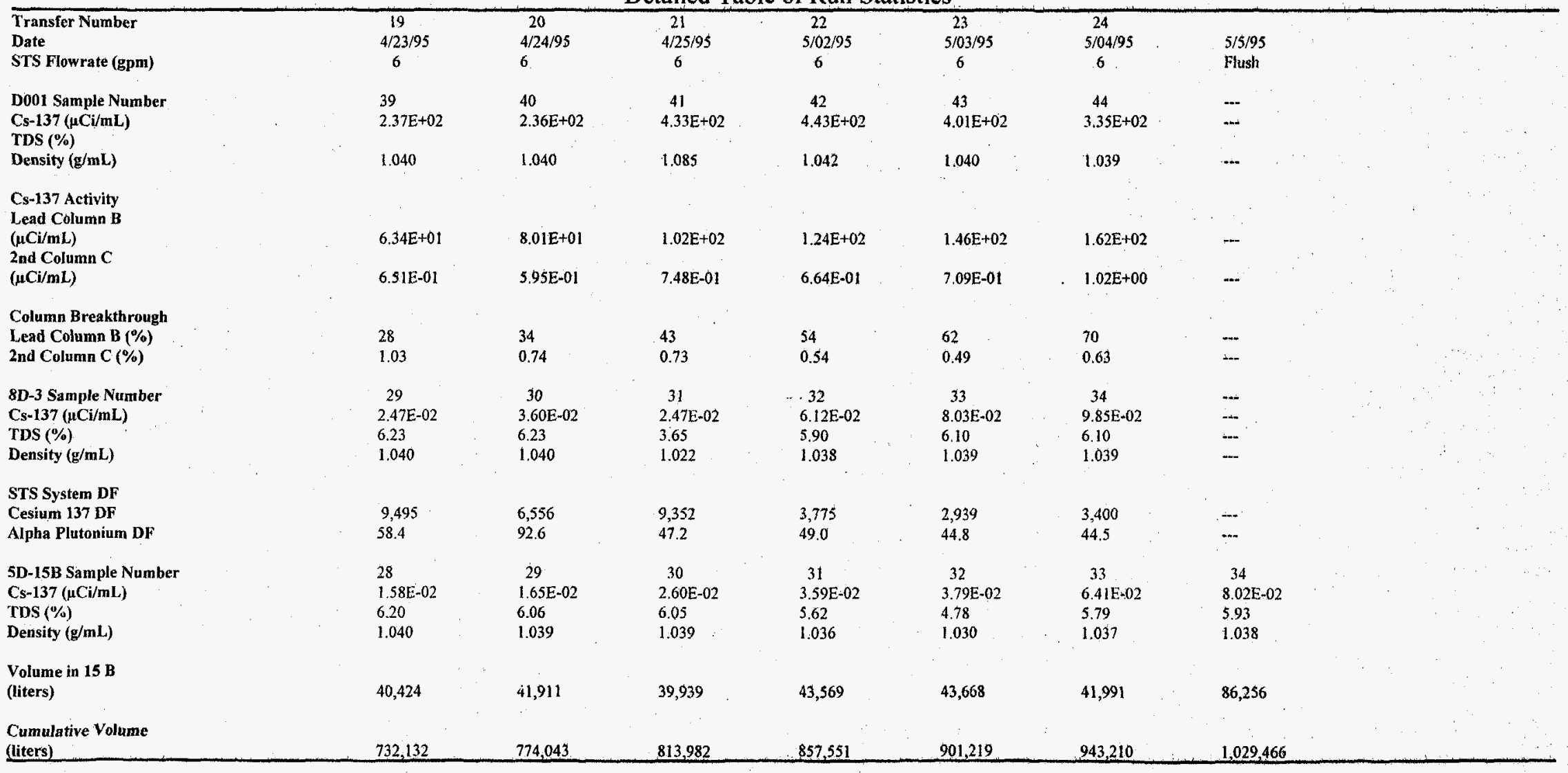




\subsection{CONCLUSION}

The results from the TIE-96 qualification test program and full-scale processing experience has demonstrated that TIE-96 can provide the required performance in the STS during sludge wash processing. The TIE-96 product that was developed by PNL and scaled up and manufactured by UOP, was available in the commercial quantities needed to support Tank $8 \mathrm{D}-2$ sludge wash processing.

Prior to full-scale use, laboratory-scale testing over a wide range of operating conditions demonstrated the effectiveness of TIE-96 for the removal of Cs-137, Pu, and Sr-90 from Tank 8D-2 alkaline sludge wash solutions. The high-pH solutions expected and used during sludge wash processing did not degrade, fuse together, or plug the IE-96 or TIE-96 zeolite in the ion-exchange columns.

The titanium associated with TIE-96 will not separate from the zeolite nor flush from the column during operating conditions. During laboratory column tests, no titanium was detected in the column effluent samples. The titanium treatment of the IE-96 appears to enhance the attrition resistance of the zeolite particles. Fewer fines are generated from normal handling of the material.

Table 42 provides a direct comparison of the chemical and physical properties between the IE-96 and TIE-96 material specifications. The TIE-96 was accommodated without modification to the existing STS equipment and is compatible with the subsequent vitrification process. TIE-96 was handled like IE-96; it involved no special requirements for STS operations or use.

Issues concerning the use of TIE-96 for sludge washing were fully addressed prior to processing sludge wash and THOREX wash solutions.

A summary of the column-feed solutions that have been employed in qualification tests and processed in fullscale operations is provided in Table 43. Laboratory column-testing was completed with actual Tank 8D-2 sludge wash and sludge wash solutions prepared from Tank 8D-2 sludge samples. Although the solutions are not identical, they show the range of solutions that the TIE-96 zeolite can process to the required decontamination level.

Full-scale experience with the TIE-96 demonstrated that the required Cs-137 DFs of 1,000 and Pu DFs of 10 can be achieved. Higher STS system Cs-137 DFs can be achieved by employing alternating columns of IE-96 and TIE-96 zeolite in the three-column STS operation.

Laboratory data during qualification testing confirmed that the short run times used at the STS (approximately 3 to 4 days) are not good for the Pu DFs. Laboratory data has shown that the DFs during the beginning of the cycle are very low (approximately 1 to 3 ), but the DFs increase significantly after approximately 36 hours of processing. The short run time at STS is attributed to the limited tank volume available downstream of the STS operations in LWTS and CSS.

The cement waste-form produced from the Tank 8D-2 sludge wash after decontamination in the TIE-96 ionexchange columns contains less curies of activity than the cement waste-form generated during supernatant treatment. During sludge wash and THOREX wash processing, 9,216 of 9,484 cement-waste drums produced were Class $A$ low-level radioactive waste form. The 268 Class $C$ cement-drums were produced during the transition from supernatant to sludge wash solution processing using a cement recipe that was no longer used. 
The exact mechanism explaining the Pu removal is not fully understood. The Pu that is removed by TIE-96 will remain on the column under sludge wash processing conditions. Laboratory testing did demonstrate that some $\mathrm{Pu}$ could be removed from the TIE-96 during a simulated recirculation mode of STS, but only $0.15 \%$ of the $\mathrm{Pu}$ initially retained during sludge wash processing was removed during recirculation. This did not pose a problem in the STS.

With the use of TIE-96, the STS should be operated to optimize Cs-137 removal. The STS should be operated at the lower temperature, lower flow rates, and higher dilutions known to improve Cs-137 removal. Laboratory testing has shown that these conditions do not significantly reduce Pu removal.

The recommended process control parameters are as follows: ${ }^{22}$

- Lead column inlet temperature $\approx 12^{\circ} \mathrm{C}$ with $16^{\circ} \mathrm{C}$ maximum

- Dilution to $\approx 10 \%$ Total Dissolved Solids (TDS), with $15 \%$ TDS maximum

- Flow rate through columns $\approx 6$ gallons per minute, with $8 \mathrm{gpm}$ maximum

- STS feed or influent (exclusive of flush water and recirculation solution) $\mathrm{pH}$ range between 12.2 to 12.6. Recommended operating limits are between 11.8 and 12.6, excluding flush and recirculation operations.

Recirculation is a special case since laboratory test data indicated some of the Pu and Sr-90 retained by TIE-96 may go into solution during recirculation. Dilution of the sludge wash with demineralized water should be as in supernatant operations. At the completion of recirculation periods, sampling is required to analyze for $\mathrm{Cs}-137, \mathrm{Pu}, \mathrm{Sr}-90$, and $\mathrm{pH}$. Depending on the concentrations obtained and requirements for LWTS and ultimately the cement recipe, this recirculation solution may be processed to LWTS or flushed back to Tank 8D-2. 
Table 42. Chemical and Physical Comparison of TIE-96 and IE-96 Zeolite

Analysis

(1) $\mathrm{Na}_{2} \mathrm{O}$

(2) $\mathrm{SiO}_{2}$

(3) $\mathrm{Al}_{2} \mathrm{O}_{3}$

(4) $\mathrm{K}_{2} \mathrm{O}$

$(1)+(2)+(3)+(4)$

$\mathrm{Fe}_{2} \mathrm{O}_{3}$

$\mathrm{CaO}$

$\mathrm{MgO}$

$\mathrm{TiO}_{2}$

$\mathrm{TiO}_{2}$

Cesium $R_{d}$

$\mathrm{Cl}$

All others

LOI@ $1000^{\circ} \mathrm{C}(w t \%)$

Density (lbs/ $\left.\mathrm{ft}^{3}\right)$

Screen, U.S. Mesh

$$
\begin{aligned}
& \%-14 \text { mesh } \\
& \%-20 \text { mesh } \\
& \%-50 \text { mesh } \\
& \%-100 \text { mesh } \\
& \%-200 \text { mesh }
\end{aligned}
$$

$\mathrm{TiO}_{2}$ Wet attrition \% loss

$\mathrm{TiO}_{2}$ Dry attrition $\%$ loss

Wet attrition \% loss

Dry attrition \% loss
TIE-96 Zeolite Specification per WVNS-MA-104

$6.31 \%$ minimum

$18.9 \%$ maximum

$1.46 \%$ maximum

$87.3 \%$ minimum

$4.85 \%$ maximum

$1.46 \%$ maximum

$0.97 \%$ maximum

$--$

Coating $4.0-6.0 \%$

$35.0 \mathrm{ml} / \mathrm{g}$ minimum

$0.020 \%$ maximum

$1.94 \%$ maximum

$25 \%$ maximum

58 maximum

100 minimum

96 minimum

1.0 maximum

0.4 maximum

0.1 maximum

$6.0 \%$ maximum

$2.0 \%$ maximum

$---n / a-\cdots$

$---n / a---$
IE-96 Zeolite Specification per WVNS-MA-103

$6.50 \%$ minimum

$19.5 \%$ maximum

$1.50 \%$ maximum

$90.0 \%$ minimum

$5.00 \%$ maximum

$1.50 \%$ maximum

$1.00 \%$ maximum

$0.50 \%$ maximum

$35.0 \mathrm{ml} / \mathrm{g}$ minimum

$2.00 \%$ maximum

$25 \%$ maximum

58 maximum

100 minimum

96 minimum

1.0 maximum

0.4 maximum

0.1 maximum

---n/a---

---n/a---

$6.0 \%$ maximum

$2.0 \%$ maximum 
Table 43.

Comparison of Undiluted Sludge Wash Solutions Processed through TIE-96 Zeolite Columns

\begin{tabular}{|c|c|c|c|c|c|c|c|c|}
\hline Analysis & $\begin{array}{l}\text { WVNS- } \\
\text { TP-032 }\end{array}$ & $\begin{array}{l}\text { WVNS- } \\
\text { TP-036 } \\
\end{array}$ & $\begin{array}{l}\text { WVNS- } \\
\text { TP-039 }\end{array}$ & $\begin{array}{c}\text { WVNS-TP- } \\
037 \mathrm{~B} \\
\end{array}$ & $\begin{array}{c}\text { Sludge Wash } \\
\# 1 \text { Average }\end{array}$ & $\begin{array}{c}\text { Sludge } \\
\text { Wash \#2 } \\
\end{array}$ & $\begin{array}{l}\text { WVNS- } \\
\text { TP-071 }\end{array}$ & $\begin{array}{c}\text { THOREX } \\
\text { Wash } \\
\end{array}$ \\
\hline $\begin{array}{l}\text { Total Dissolved Solids } \\
\text { (TDS) wt } \%\end{array}$ & 23.3 & 20.9 & .22 & 21.1 & 17.5 & 2.94 & 6.08 & 5.75 \\
\hline Density $(\mathrm{g} / \mathrm{ml})$ & 1.186 & 1.162 & 1.178 & 1.161 & 1.133 & 1.020 & 1.037 & 1.038 \\
\hline $\mathrm{pH}$ & $>12.0$ & 12.20 & 12.10 & 12.60 & 12.4 & 11.80 & 12.15 & 11.7 \\
\hline alpha-Pu $(\mu \mathrm{Ci} / \mathrm{ml})$ & $1.36 \mathrm{E}-1$ & $6.85 \mathrm{E}-2$ & $1.84 \mathrm{E}-1$ & $3.02 \mathrm{E}-2$ & $1.49 \mathrm{E}-2$ & $1.91 \mathrm{E}-3$ & $4.45 \mathrm{E}-5$ & $4.30 \mathrm{E}-5$ \\
\hline $\mathrm{Cs}-137(\mu \mathrm{Ci} / \mathrm{ml})$ & $9.65 \mathrm{E}+2$ & $9.32 \mathrm{E}+2$ & $8.97 \mathrm{E}+2$ & $9.25 \mathrm{E}+2$ & $6.92 \mathrm{E}+2$ & $9.17 \mathrm{E}+1$ & $2.54 \mathrm{E}+2$ & $2.59 \mathrm{E}+2$ \\
\hline $\mathrm{Sr}-90(\mu \mathrm{Ci} / \mathrm{ml})$ & $1.41 \mathrm{E}+0$ & $6.68 \mathrm{E}-1$ & $6.61 \mathrm{E}-2$ & $2.94 \mathrm{E}-1$ & $3.70 \mathrm{E}-1$ & $3.48 \mathrm{E}-2$ & $3.12 \mathrm{E}-1$ & $5.96 \mathrm{E}-1$ \\
\hline $\mathrm{U}(\mu \mathrm{g} / \mathrm{g})$ & 52.5 & 14.7 & 18.1 & 8.86 & 4.71 & 3.29 & $\mathrm{n} / \mathrm{a}$ & 0.341 \\
\hline $\mathrm{Na}(\mu \mathrm{g} / \mathrm{g})$ & 66,000 & 64,700 & 63,900 & 87,000 & 54,400 & 8,300 & 16,290 & 17,567 \\
\hline $\mathrm{NO}_{2}^{*}(\mu \mathrm{g} / \mathrm{g})$ & 51,500 & 47,800 & 46,000 & 52,900 & 45,000 & 8,770 & 14,160 & 18,514 \\
\hline $\mathrm{NO}_{3}^{-}(\mu \mathrm{g} / \mathrm{g})$ & 59,300 & 56,800 & 45,260 & 55,700 & 44,100 & 5,310 & 20,950 & 19,018 \\
\hline $\mathrm{SO}_{4}^{-}(\mu \mathrm{g} / \mathrm{g})$ & 30,600 & 21,800 & 23,570 & 19,700 & 17,630 & 2,780 & 790 & 830 \\
\hline $\mathrm{Cl}^{-}(\mu \mathrm{g} / \mathrm{g})$ & $\mathrm{n} / \mathrm{a}$ & 420 & $\mathrm{n} / \mathrm{a}$ & 554 & 528 & 84 & 208 & 217 \\
\hline $\mathrm{Al}(\mu \mathrm{g} / \mathrm{g})$ & 340 & 1,080 & 744 & 331 & 248 & 41 & 148 & 171 \\
\hline
\end{tabular}

All WVNS-TPs were laboratory-prepared solutions used in column testing All washes are actual, full-scale Tank 8D-2 solutions 


\subsection{REFERENCES}

1 L. A. Bray, F. T. Hara, "Use of Titanium-Treated Zeolite for Pu, Sr-90, and Cs-137 Removal form West Valley Alkaline Wastes and Sludge Wash Waters", Presented at the First Hanford Separations Science Workshop, Richland, Washington. PNL-SA-19697 S, Pacific Northwest Laboratory, Richland, Washington, BW:91:0051, WVSP 91-049, July 1991.

2 L. Bray, K. Carson, R. Elovich, "Use of Titanium-Treated Zeolite for Pu, Sr-90 and Cs-137 Removal from West Valley Alkaline Wastes and Sludge Wash Waters," WVSP 91-010, BW:90:0124, December 1990.

3 L. Bray, F. Hara, T. Kazmierczak, "Removal of Pu from West Valley High-level Liquid Wastes", DJS0373:6RM, January 1991.

W. J. Dalton, "Test Plan for the Qualification of Titanium-treated Zeolite for the Processing of Sludge Wash Liquid", WVNS-TPL-50-003, Revision 2, dated April 10, 1992.

W. J. Dalton, " $\mathrm{R}_{d}$ - "Batch Distribution" and Column Testing of Titanium-coated IE-96 Zeolite Samples Prepared by UOP", WVNS-TSR-023, Revision 0, dated March 10, 1992.

W. J. Dalton, "Qualification Testing on the 100 LB Pilot-Scale TIE-96 Zeolite Prepared by UOP", WVNS-TSR-033, Revision 0, dated January. 31, 1992.

W. J. Dalton, "Tank 8D-2 Sludge Washing with a 130-inch Nominal Heel", WVNS-TSR-032, Revision 0, dated March 6, 1992.

W. J. Dalton, "TIE-96 Zeolite Testing for Defining STS Operating Conditions", WVNS-ȚSR-037A, Revision 0, dated January 24, 1992.

W. J. Dalton, "Tank 8D-2 Sludge Washing with Core Samples and a 130 Inch Nominal Heel", WVNS-TSR-036, Revision 0, dated January 20, 1992.

W. J. Dalton, "TIE-96 Zeolite Testing for Defining STS Operating Conditions", WVNS-TSR-037B, Revision 0, dated March 31, 1992.

11 D. E. Carl, "STS Column Loading Verification with TIE-96 Zeolite", WVNS-TSR-042, Revision 0, dated March 31, 1992. 7,200 lb Production of TIE-96", WVNS-TSR-039, Revision 0, dated March 27, 1992.

L. Bray, "Caustic Effects on Zeolite Stability," WVSP 91-055, BW:91:0060, December 1991. WVSP 92-13, BW:92:0001. December 1991. 
DOE/NE/44139-47 (DE89009020), December 1988.

17 A. J. Howell to J. Paul, "IRTS Campaign No. 22-1S Run Report," DC:92:0151, November 19, 1992.

18 A. J. Howell to J. Paul, "IRTS Campaign No. 23-1S Run Report," JF:93:0060, May 4, 1993.

19 A. J. Howell to J. Paul, "IRTS Campaign No. 24-1S Run Report," JF:93:0097, July 27, 1993.

20 A. J. Howell to J. Paul, "IRTS Campaign No. 25-1S Run Report," JF:94:0023, April.26, 1994.

21 G. A. Smith to J. Paul, "IRTS Campaign No. 26-1 S, 27-1S, 28-1 S, and 29-1S-2S Run Reports," JF:95:0004, January 10, 1995.

22 D. E. Carl to A. J. Howell, "Modifications to System 50 SOP's for Sludge Wash Processing," CD:92:0088, March 25, 1992. 